\author{
UNIVERSIDADE DE SÃO PAULO \\ ESCOLA DE ENGENHARIA DE SÃO CARLOS \\ DEPARTAMENTO DE ENGENHARIA DE ESTRUTURAS
}

FRANCIELLE DA SILVA RODOVALHO

SIMULAÇÃO NUMÉRICA DE BLOCOS E PRISMAS DE ALVENARIA EM SITUAÇÃO DE INCÊNDIO

SÃO CARLOS 



\title{
SIMULAÇÃO NUMÉRICA DE BLOCOS E PRISMAS DE ALVENARIA EM SITUAÇÃO DE INCÊNDIO
}

\author{
VERSÃO CORRIGIDA \\ A versão original encontra-se na Escola de Engenharia de São Carlos
}

Dissertação apresentada ao Departamento de Engenharia de Estruturas da Escola de Engenharia de São Carlos, Universidade de São Paulo, como parte dos requisitos necessários para obtenção do título de Mestre em Engenharia Civil (Estruturas).

Orientador: Prof. Dr. Márcio Roberto Silva Corrêa 


\section{AUTORIZO A REPRODUÇÃO TOTAL OU PARCIAL DESTE TRABALHO, POR QUALQUER MEIO CONVENCIONAL OU ELETRO̊NICO, PARA FINS DE ESTUDO E PESQUISA, DESDE QUE CITADA A FONTE.}

Ficha catalográfica elaborada pela Biblioteca Prof. Dr. Sérgio Rodrigues Fontes da EESC/USP com os dados inseridos pelo(a) autor(a).

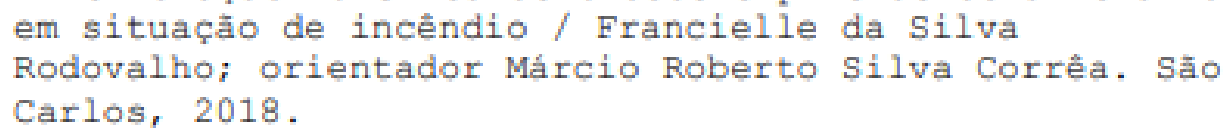

1. Alvenaria estrutural. 2. Blocos de concreto. 3. Elevadas temperaturas. 4. Análise numérica. 5. Simulaçōes térmicas. 6. Simulaçōes termomecănicas. 7 . Situaçăo de incêndio. I. Título. 


\section{FOLHA DE JULGAMENTO}

Candidata: Bacharela FRANCIELLE DA SILVA RODOVALHO.

Título da dissertação: "Simulação numérica de blocos e prismas de alvenaria em situação de incêndio".

Data da defesa: 23/05/2018.

Comissão Julgadora:

Resultado:

Prof. Associado Marcio Roberto Silva Corrêa

APRO YADO

(Orientador)

(Escola de Engenharia de São Carlos/EESC)

Prof. Dr. Guilherme Aris Parsekian

(Universidade Federal de São Carlos/UFSCar)

Aprovado

Prof. Dr. Armando Lopes Morenos Junior

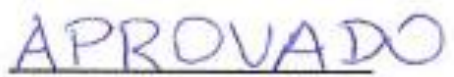

(Universidade Estadual de Campinas/UNICAMP)

Coordenador do Programa de Pós-Graduação em Engenharia Civil (Engenharia de Estruturas):

Prof. Titular Humberto Breves Coda

Presidente da Comissão de Pós-Graduação:

Prof. Associado Luís Fernando Costa Alberto 

Dedico aos meus pais,

Cláudio e Lúcia. 

"Não diga que a canção está perdida,

Tenha fé em Deus tenha fé na vida"

Raul Seixas 



\section{AGRADECIMENTOS}

Agradeço primeiramente a Deus pela vida e por me dar forças para sempre seguir em frente.

Aos meus pais Cláudio e Lúcia por todo apoio, carinho e dedicação, sendo a base para que eu pudesse concluir mais esta etapa.

Aos meus irmãos Danilo e Diogo e à minha avó Altina (in memoriam) por me ajudarem e sempre acreditarem na minha capacidade.

Ao meu namorado Guilherme que me encorajou a ir para São Carlos e familiares que torceram por mim.

Aos professores da UFTM que me aconselharam e incentivaram a seguir este caminho.

Ao meu orientador Márcio Roberto Silva Corrêa por me auxiliar no desenvolvimento deste trabalho com toda sua sabedoria e paciência.

Aos professores Jorge Munaiar Neto e Vladimir Guilherme Haach pelas contribuições fornecidas no exame de qualificação.

Aos demais professores que me transmitiram um pouco de conhecimento e aos funcionários do Departamento de Estruturas pelo suporte.

Ao Pablo Krahl, à Carol Rezende e à Rafaela Amaral (Unicamp) pela ajuda com as ferramentas do software Abaqus.

$\grave{A}$ empresa Glasser por ter concedido os resultados de um ensaio de alvenaria em situação de incêndio.

Aos amigos da carona que contribuíram para diminuir a distância entre São Carlos e Uberaba. Àqueles de Uberaba, que conheci no Colégio Tiradentes e durante a graduação, os quais se mantiveram presentes mesmo depois muitos anos.

Às amizades que tive a oportunidade de fazer no Departamento de Estruturas com os integrantes da "panela mestranda", Alex, Rafaella, Giovane, e também da área de incêndio, Felipi, Vanessa e Yagho, pela parceria e por sempre estarem dispostos a me ajudar.

Em especial àqueles da ME-05, Emerson, Fabiana, Tito e Mariana, pelo companheirismo, boas conversas e principalmente por me fazerem rir até nos piores momentos.

Por fim agradeço ao Conselho Nacional de Desenvolvimento Científico e Tecnológico pela bolsa concedida. 



\section{RESUMO}

RODOVALHO, F. S. Simulação numérica de blocos e prismas de alvenaria em situação de incêndio. 2018. 158 p. Dissertação (Mestrado em Engenharia Civil (Estruturas)). Escola de Engenharia de São Carlos, Universidade de São Paulo, São Carlos, 2018.

A alvenaria estrutural é um sistema construtivo muito antigo no qual as paredes exercem função estrutural além da função de vedação. Este sistema construtivo é muito utilizado no Brasil, entretanto, poucas pesquisas foram realizadas sobre o seu comportamento em situação de incêndio e o país ainda não possui métodos normativos de dimensionamento de alvenaria estrutural em situação de incêndio. Assim, o objetivo deste trabalho foi verificar o desempenho da alvenaria estrutural com blocos de concreto submetida a elevadas temperaturas através da simulação de prismas. No software Abaqus foram simulados o comportamento do bloco e prisma sujeitos à compressão em temperatura ambiente e do prisma em situação de incêndio com diferentes condições de contorno. O comportamento do bloco e prisma sujeitos à compressão e em temperatura ambiente foi validado até a carga última. As elevações de temperatura das faces não expostas ao fogo ficaram bem representadas por meio das simulações térmicas. A perda de resistência dos materiais foi adotada conforme a literatura técnica nas simulações termomecânicas. Através do que foi analisado no trabalho observou-se que os prismas se comportam bem quanto ao isolamento térmico em situação de incêndio, principalmente aquele com revestimento em argamassa nas duas faces. Quanto ao critério de resistência mecânica os resultados numéricos não foram validados com experimentais, entretanto, foi possível representar a deterioração térmica dos materiais.

Palavras-chave: Alvenaria estrutural. Blocos de concreto. Elevadas temperaturas. Análise numérica. Simulações térmicas. Simulações termomecânicas. Situação de incêndio. 



\begin{abstract}
RODOVALHO, F. S. Numerical simulation of masonry blocks and prisms under fire situation. 2018. 158 p. Dissertation (M. Sc. in Civil Engineering (Structures)) - School of Engineering of São Carlos, University of São Paulo, São Carlos, 2018.

The structural masonry is a very old building system in which the walls have structural and partition function. The use of this building system is widely spread in Brazil, however, few research programs were carried out on their behavior under fire situation and the country has not yet developed standard normative methods for designing structural masonry subject to fire. Thus the purpose of this research was to verify the performance of concrete blockwork structural masonry submitted to high temperatures through the simulation of prisms. In the Abaqus software the behavior of block and prism subjected to compression at room temperature and of the prism under fire situation with different boundary conditions were simulated. The compression of the block and prism at room temperature was validated until ultimate loads. The temperature rises of the non-exposed faces were well represented through thermal simulations. The material's resistance loss was adopted according to the technical literature in the thermomechanical simulations. Based on the analyzed examples it was observed that the prisms behave well regarding the thermal insulation under fire situation, mainly when having mortar coating on both sides. Regarding the mechanical resistance criterion, the numeric results were not validated with experimental ones, however, it was possible to represent the thermal deterioration of the materials.
\end{abstract}

Keywords: Structural masonry. Concrete blocks. High temperatures. Numerical analysis. Thermal simulations. Thermomechanical simulations. Fire situation. 



\section{LISTA DE FIGURAS}

Figura 1 - Incêndios em edificações

Figura 2 - Distribuição de incêndio no mundo conforme sua origem no ano de 2015

Figura 3 - Razão entre resistência à tração e compressão para unidades cerâmicas

Figura 4 - Razão entre resistência à tração e compressão para blocos de concreto

Figura 5 - Relação da composição da argamassa com a resistência à compressão e a retenção de água

Figura 6 - Tetraedro do fogo

Figura 7 - Fases de um incêndio real

Figura 8 - Curvas padronizadas para incêndio 36

Figura 9 - TRRF ou tempo equivalente 37

Figura 10 - Mecanismos de transferência de calor 38

Figura 11 - Situação estacionária de condução em um elemento composto 40

Figura 12 - Espectro eletromagnético. 44

Figura 13 - Radiação incidente sobre uma superfície..... 47

Figura 14 - Condutividade térmica e calor específico de unidades cerâmicas 49

Figura 15 - Variação do coeficiente de expansão térmica de bloco cerâmico. 50

Figura 16 - Limites superior e inferior de condutividade térmica do concreto 52

Figura 17 - Variação do calor específico do concreto conforme o teor de umidade 52

Figura 18 - Deformação térmica de concretos com diferentes tipos de agregados 54

Figura 19 - Influência da temperatura sobre a resistência à compressão do concreto 55 Figura 20 - Redução da resistência à compressão da argamassa com a elevação de temperatura 56

Figura 21 - Redução do módulo de elasticidade da argamassa com a elevação de temperatura 
Figura 22 - Técnicas de modelagem da alvenaria: (a)Esquema da alvenaria; (b)Micromodelagem; (c)Micromodelagem simplificada; (d)Macromodelagem ................ 58

Figura 23 - Principais mecanismos de ruptura da alvenaria ............................................ 59

Figura 24 - Diagrama tensão-deslocamento de materiais frágeis: (a)Tração;

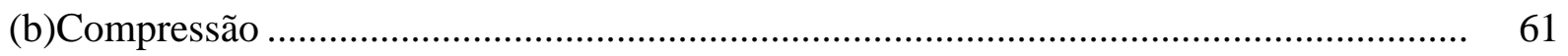

Figura 25 - Diagrama tensão de cisalhamento-deslocamento de materiais frágeis ............. 62

Figura 26 - Comportamento do modelo: (a)Tracionado (b)Comprimido uniaxialmente .... 63

Figura 27 - Resistência do concreto em estado biaxial de tensões.................................. 65

Figura 28 - Superfície de resistência para diferentes valores de Kc ............................... 66

Figura 29 - Curvatura da parede e expansão longitudinal da laje ..................................... 67

Figura 30 - Dimensões do bloco de concreto utilizadas na simulação $(\mathrm{mm})$...................... 76

Figura 31 - Malha utilizada no bloco de concreto .......................................................... 76

Figura 32 - Esquema de compressão do bloco ............................................................ 79

Figura 33 - Ensaio de compressão do bloco de concreto .................................................. 79

Figura 34 - Tensão-deformação média dos blocos de concreto na área líquida.................. 80

Figura 35 - Comparação dos diagramas tensão-deformação do bloco na área líquida ....... 81

Figura 36 - Distribuição de tensões principais máximas no bloco $(\mathrm{Pa})$............................ 82

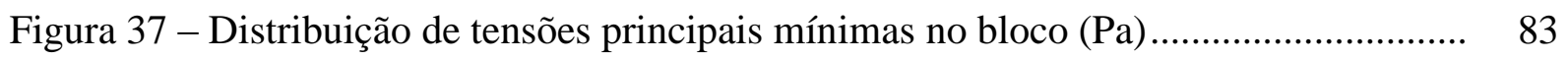

Figura 38 - Modo de ruptura do bloco de concreto ......................................................... 83

Figura 39 - Malhas utilizadas nas argamassas....................................................... 84

Figura 40 - Esquema de compressão dos prismas de três blocos .................................... 86

Figura 41 - Esquema de compressão dos prismas de dois blocos ................................ 87

Figura 42 - Ensaio de compressão do prisma de três blocos com argamassamento

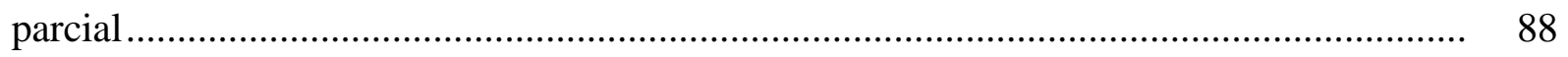

Figura 43 - Comparação dos diagramas tensão-deformação dos prismas de três blocos com

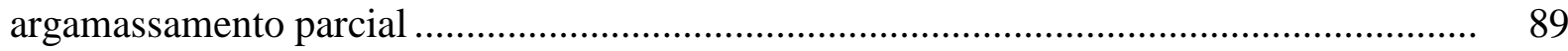


Figura 44 - Distribuição de tensões principais no prisma de três blocos com argamassamento parcial $(\mathrm{Pa})$

Figura 45 - Modo de ruptura do prisma de três blocos com argamassamento parcial......... 92 Figura 46 - Diagramas tensão-deformação numéricos dos prismas constituídos por blocos de concreto

Figura 47 - Distribuição de tensões principais no prisma de três blocos com argamassamento total $(\mathrm{Pa})$

Figura 48 - Distribuição de tensões principais no prisma de dois blocos com argamassamento parcial $(\mathrm{Pa})$

Figura 49 - Distribuição de tensões principais no prisma de dois blocos com argamassamento total $(\mathrm{Pa})$

Figura 50 - Modo de ruptura do prisma de dois blocos com argamassamento total 97

Figura 51 - Geometria e dimensões do bloco cerâmico e do revestimento (mm)

Figura 52 - Malhas utilizadas nas modelagens cerâmicas

Figura 53 - Esquema das modelagens térmicas das paredes cerâmicas

Figura 54 - Elevação de temperatura nas faces não expostas ao fogo das paredes cerâmicas

Figura 55 - Campos térmicos desenvolvidos na parede sem revestimento $\left({ }^{\circ} \mathrm{C}\right)$ 105

Figura 56 - Campos térmicos desenvolvidos na parede com revestimento $\left({ }^{\circ} \mathrm{C}\right)$ 106

Figura 57 - Malha utilizada no prisma revestido

Figura 58 - Esquema da modelagem térmica do prisma com revestimento em uma face... 108

Figura 59 - Malha utilizada na massa de ar

Figura 60 - Condutividade térmica de diversos materiais

Figura 61 - Elevação de temperatura nas faces não expostas ao fogo experimental e numérico

Figura 62 - Elevação de temperatura em diversos pontos do prisma com revestimento em uma face. 
Figura 63 - Campos térmicos desenvolvidos no prisma com revestimento em uma face e na massa de ar $\left({ }^{\circ} \mathrm{C}\right)$

Figura 64 - Planos de simetria do prisma

Figura 65 - Elevação de temperatura em diversos pontos do prisma sem revestimento.....

Figura 66 - Campos térmicos desenvolvidos no prisma sem revestimento e uma face exposta ao incêndio $\left({ }^{\circ} \mathrm{C}\right)$.

Figura 67 - Esquema do prisma com revestimento nas duas faces e uma exposta ao fogo

Figura 68 - Malha utilizada no prisma com revestimento nas duas faces

Figura 69 - Elevação de temperatura em diversos pontos do prisma com revestimento nas duas faces

Figura 70 - Campos térmicos desenvolvidos no prisma com revestimento em argamassa nas duas faces $\left({ }^{\circ} \mathrm{C}\right)$.

Figura 71 - Diagrama tensão-deformação simplificado

Figura 72 - Curvas tensão-deformação conforme a temperatura do bloco

Figura 73 - Curvas tensão-deformação conforme a temperatura da argamassa

Figura 74 - Esquema de vinculação de uma parede carregada.

Figura 75 - Momento fletor adicional devido à restrição rotacional

Figura 76 - Esquema da simulação termomecânica do prisma sem revestimento

Figura 77 - Esquema do prisma sem revestimento com as duas faces expostas ao incêndio

Figura 78 - Elevação de temperatura em alguns pontos do prisma sem revestimento e com duas faces expostas ao incêndio 130

Figura 79 - Campos térmicos desenvolvidos no prisma sem revestimento e com duas faces expostas ao incêndio $\left({ }^{\circ} \mathrm{C}\right)$.

Figura 80 - Deformação axial do prisma sem revestimento e com duas faces expostas ao incêndio. 
Figura 81 - Tensões máximas e mínimas principais nos instantes considerados de ruptura $(\mathrm{Pa})$

Figura 82 - Variação da força para o prisma com restrição vertical e duas faces expostas ao incêndio

Figura 83 - Tensões máximas e mínimas principais do prisma com restrição vertical nos instantes considerados de ruptura $(\mathrm{Pa})$

Figura 84 - Deformação axial do prisma com carregamento fixo e restrição rotacional

Figura 85 - Deslocamento lateral do prisma sem revestimento com uma face exposta ao incêndio carregamento fixo e restrição rotacional

Figura 86 - Campos térmicos no instante considerado de ruptura para o carregamento de $35 \% \mathrm{f}_{\mathrm{pk}}\left({ }^{\circ} \mathrm{C}\right)$.

Figura 87 - Tensões máximas e mínimas principais desenvolvidas no prisma para o carregamento de $35 \% \mathrm{f}_{\mathrm{pk}}$ e restrição rotacional no instante de ruptura $(\mathrm{Pa})$

Figura 88 - Deformação axial do prisma com carregamento fixo e sem restrição rotacional

Figura 89 - Tensões máximas e mínimas principais desenvolvidas no prisma para o carregamento de $35 \% \mathrm{f}_{\mathrm{pk}}$ e sem restrição rotacional no instante final de processamento $(\mathrm{Pa}) 142$ Figura 90 - Variação da força para o prisma com restrição vertical e uma face exposta ao incêndio

Figura 91 - Tensões principais mínimas desenvolvidas no prisma sem restrição rotacional no instante final de processamento 144

Figura 92 - Tensões máximas e mínimas principais desenvolvidas no prisma com e sem restrição rotacional e restrição de deslocamento vertical carregado inicialmente com $35 \% \mathrm{f}_{\mathrm{pk}}(\mathrm{Pa})$ 



\section{LISTA DE TABELAS}

Tabela 1 - Valores de eficiência para o material cerâmico

Tabela 2 - Requisitos para resistência característica do bloco à compressão, absorção e retração

Tabela 3 - Valores de eficiência para blocos de concreto

Tabela 4 - Propriedades mecânicas da argamassa

Tabela 5 - Cores visíveis de objetos aquecidos

Tabela 6 - Emissividade de alguns materiais

Tabela 7 - Propriedades térmicas das unidades cerâmicas em temperatura ambiente 48

Tabela 8 - Propriedades térmicas do concreto e de blocos de concreto.....

Tabela 9 - Propriedades térmicas da argamassa em temperatura ambiente.

Tabela 10 - Parâmetros do bloco necessários para o modelo de plasticidade 78

Tabela 11 - Valores de tensão no bloco de concreto

Tabela 12 - Parâmetros da argamassa necessários para o modelo de plasticidade...... 85

Tabela 13 - Valores de tensão no prisma de três blocos com argamassamento parcial... 89

Tabela 14 - Resistência à compressão dos diferentes prismas 98

Tabela 15 - Propriedades térmicas da alvenaria cerâmica utilizadas nas simulações 102

Tabela 16 - Medidas de temperatura nas faces não expostas. 104

Tabela 17 - Propriedades térmicas do ar utilizadas na simulação

Tabela 18 - Resultados médios de elevação de temperatura nas faces não expostas

Tabela 19 - Parâmetros do diagrama tensão-deformação do concreto em elevadas temperaturas.

Tabela 20 - Resumo das simulações térmicas.

Tabela 21 - Resumo das simulações termomecânicas 



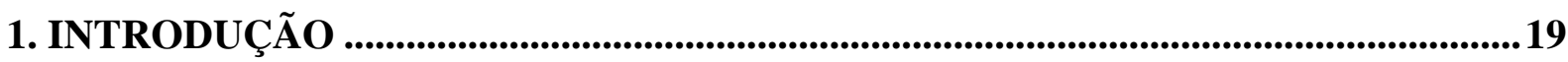

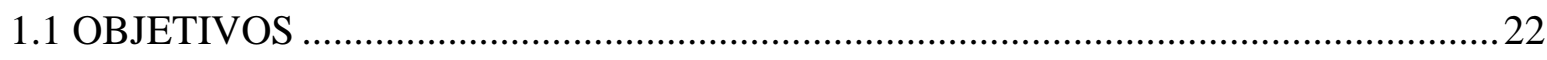

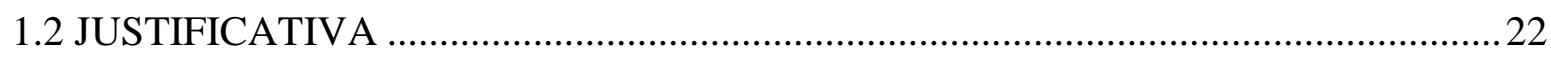

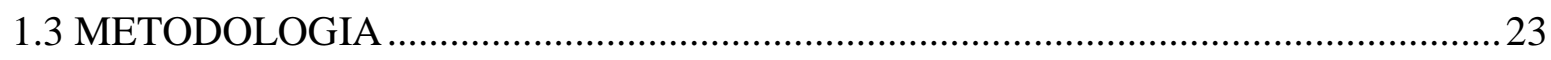

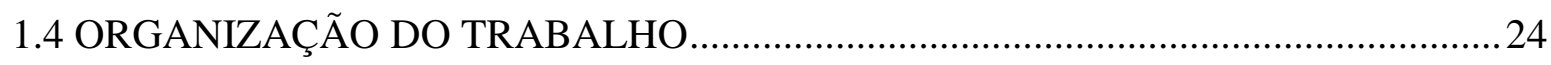

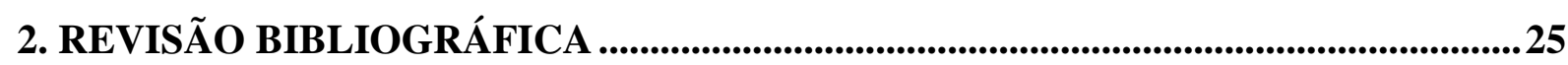

2.1 BREVE HISTÓRICO SOBRE ALVENARIA ESTRUTURAL .....................................25

2.2 CARACTERÍSTICAS DOS PRINCIPAIS COMPONETES DA ALVENARIA

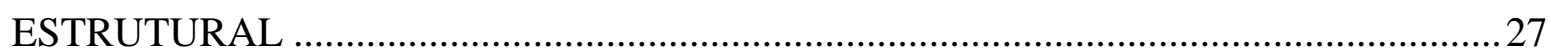

2.2.1 Bloco cerâmico.........................................................................................................................27

2.2.2 Bloco de concreto.............................................................................................................29

2.2.3 Argamassa .......................................................................................................................31

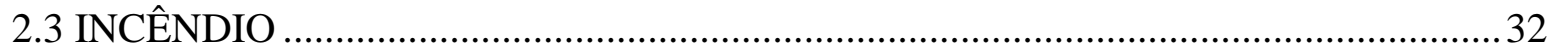

2.3.1 Incêndio-padrão ..........................................................................................................35

2.3.2 Tempo requerido de resistência ao fogo.......................................................................36

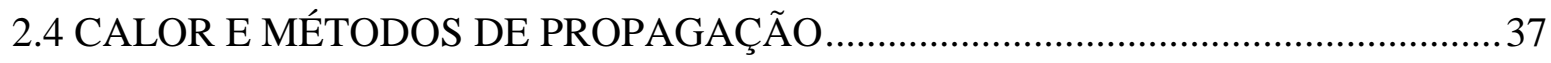

2.4.1 Condução......................................................................................................................38

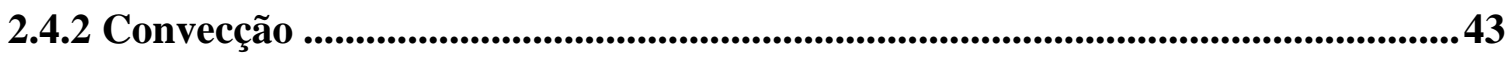

2.4.3 Radiação...............................................................................................................................44

2.5 PROPRIEDADES TÉRMICAS DOS PRINCIPAIS COMPONENTES DA

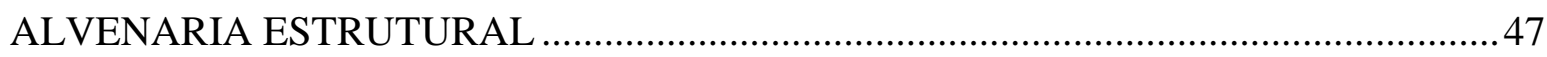

2.5.1 Unidades cerâmicas................................................................................................48

2.5.1 Unidades de concreto ...................................................................................................50

2.5.2 Argamassa..............................................................................................................55

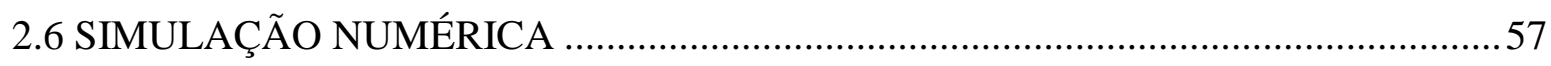

2.6.1 Análise mecânica ..............................................................................................................57

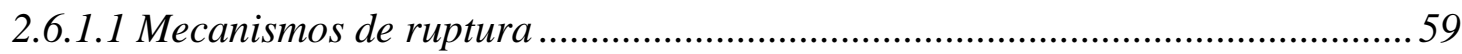

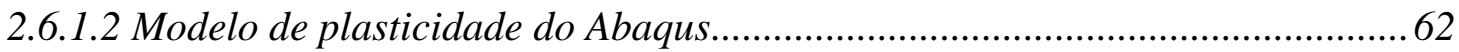

2.6.2 Análise térmica ......................................................................................................................66

2.7 ALVENARIA EM SITUAÇÃO DE INCÊNDIO ……………………………………....68 
3.1 SIMULAÇÃO DO BLOCO DE CONCRETO SUJEITO À COMPRESSÃO EM

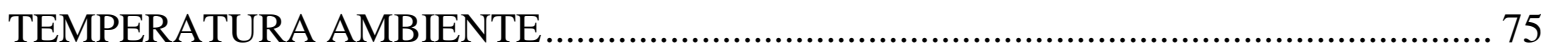

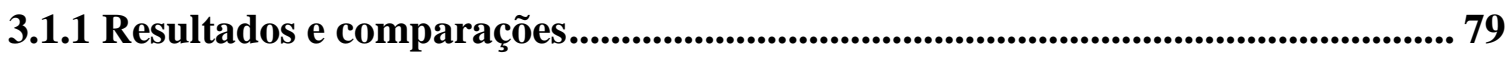

3.2 SIMULAÇÕES DOS PRISMAS COM BLOCOS DE CONCRETO SUJEITOS À COMPRESS $\tilde{A} O$ EM TEMPERATURA AMBIENTE ….............................................. 84

3.2 Resultados e comparações....................................................................................... 87

4. SIMULAÇÕES TÉRMICAS ..................................................................................... 99

4.1 SIMULAÇÕES TÉRMICAS DA ALVENARIA COMPOSTA POR BLOCOS

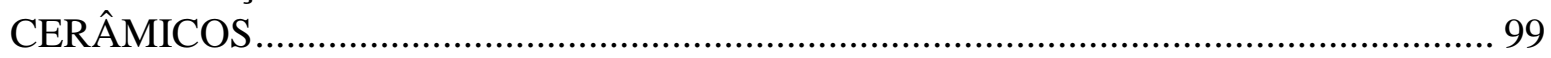

4.1.1 Resultados e comparações............................................................................. 102

4.2 SIMULAÇÕES TÉRMICAS DOS PRISMAS COMPOSTOS POR BLOCOS DE

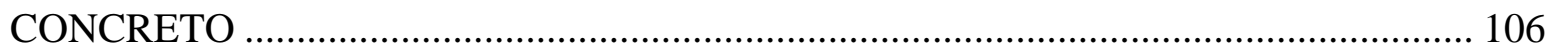

4.2.1 Validação do prisma com revestimento na face exposta ao fogo....................... 112

4.2.2 Prisma sem revestimento e uma face exposta ao incêndio ............................... 115

4.2.3 Prisma com revestimento em argamassa nas duas faces sendo uma exposta ao

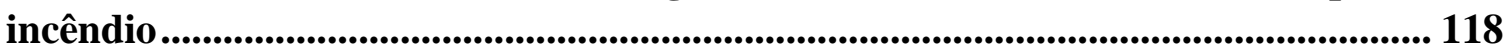

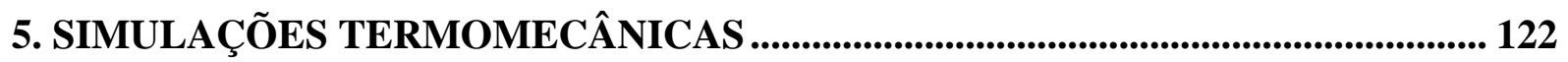

5.1. PRISMA SEM REVESTIMENTO E COM DUAS FACES EXPOSTAS AO

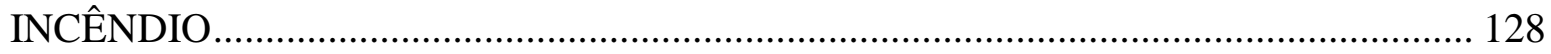

5.1.1. Resultados e comparações.............................................................................. 129

5.2. PRISMA SEM REVESTIMENTO E UMA FACE EXPOSTA AO FOGO............... 136

5.2.1. Resultados e comparações................................................................................ 137

5.2.1.1 Carregamento constante com e sem restrição rotacional ............................ 137

5.2.1.2 Restrição de deslocamento vertical com e sem restrição rotacional............. 142

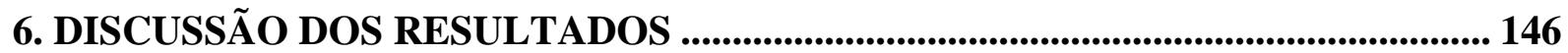

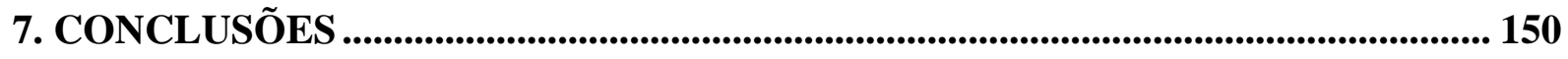

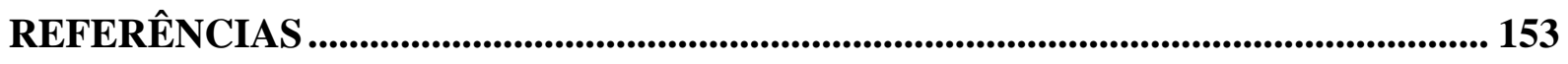




\section{INTRODUÇÃO}

Os incêndios em edificações são frequentes em todo o mundo causando perdas materiais e milhares de mortes a cada ano. A Figura 1 apresenta alguns exemplos de incêndios ocorridos em diferentes locais.

Figura 1 - Incêndios em edificações

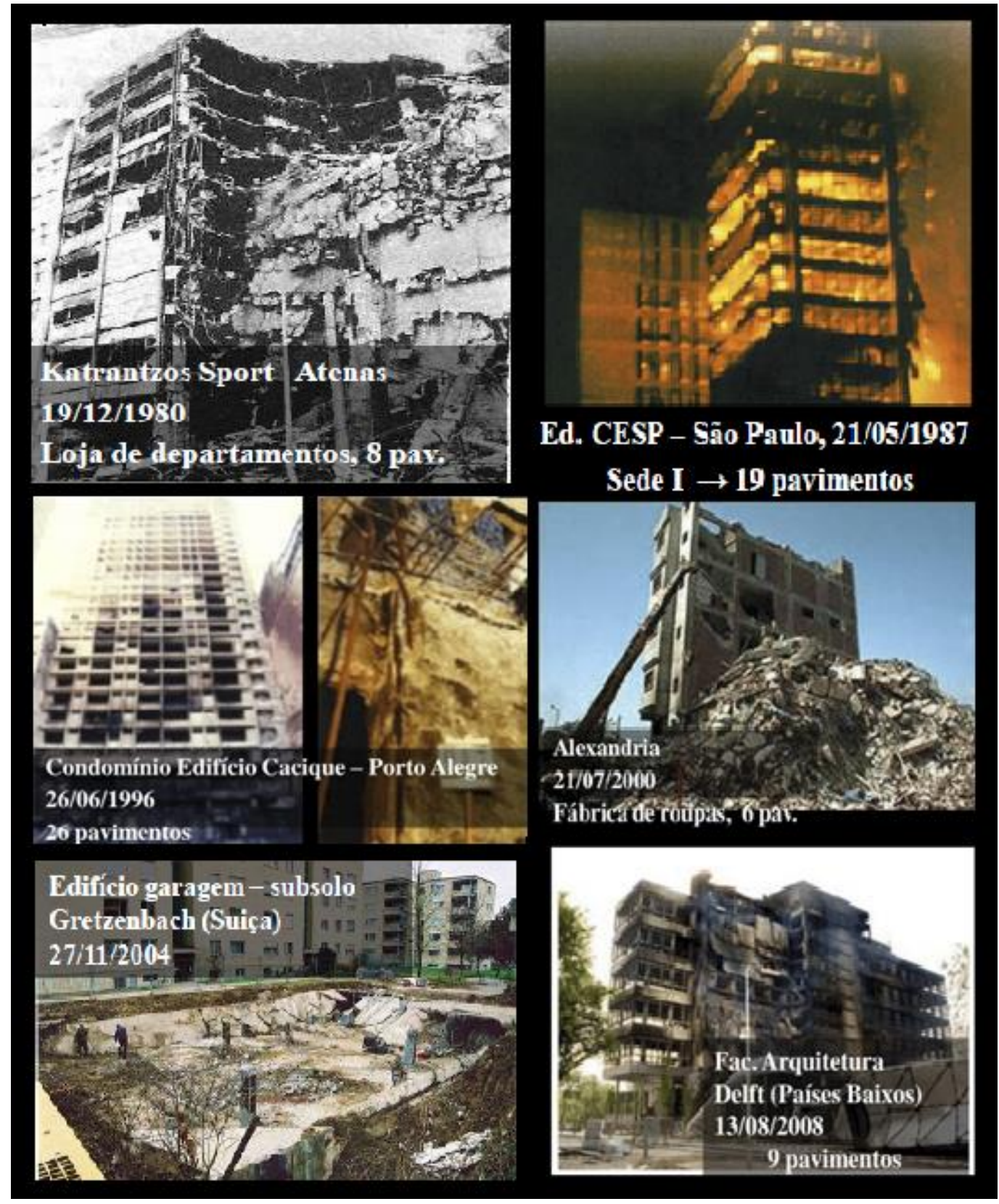

Fonte: Silva (2010) 
No dia 26 de março de 2018 ocorreu um incêndio em um shopping center na Rússia fazendo 64 vítimas fatais, incluindo crianças. Conforme BBC (2018) alarme, portas e luzes de emergência não funcionaram, havendo violação das normas de segurança contra incêndio.

Segundo o Centre of Fire Statistics - CTIF (2017) o incêndio em edificações é responsável por quase $40 \%$ das ocorrências, como pode ser observado na Figura 2.

Figura 2 - Distribuição de incêndio no mundo conforme sua origem no ano de 2015

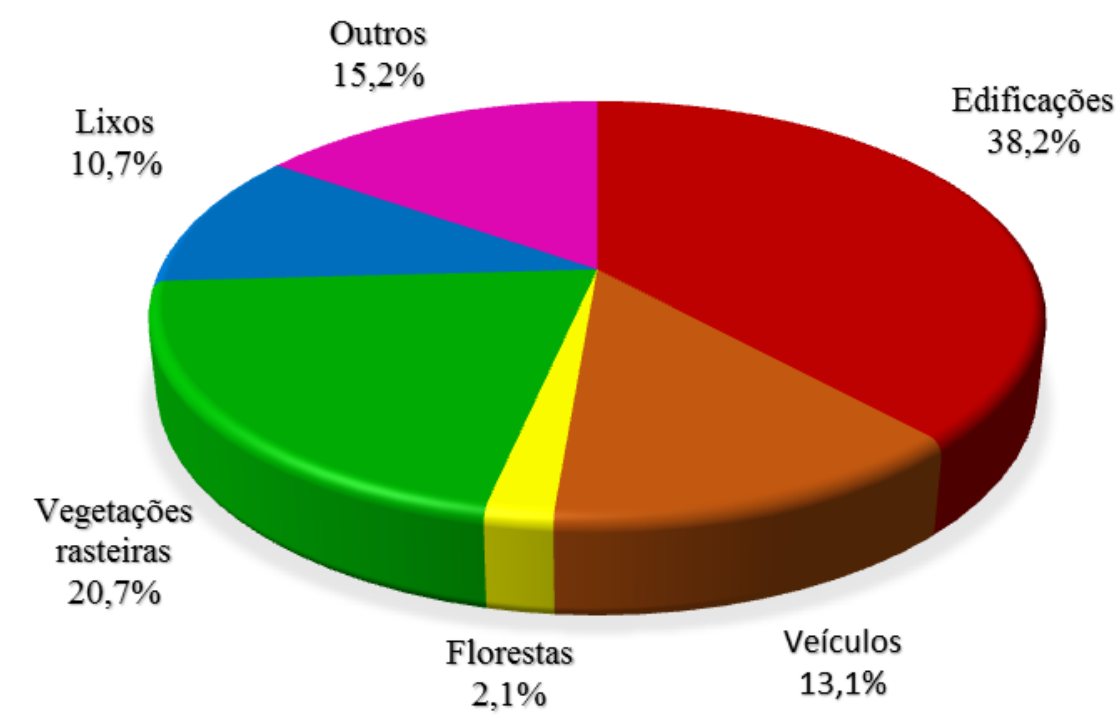

Fonte: Adaptado de IAFRS/CTIF (2017)

No Brasil, de acordo com Alves e Borborema (2015), tem-se a sensação de que incêndio não é um problema grave devido à falta de divulgação dos dados apurados pelas equipes de combate ao incêndio. Porém, se forem comparadas as causas de mortes mencionadas nos relatórios do Sistema Único de Saúde (SUS), o Brasil ficaria em terceiro com o maior número de mortes por incêndio no mundo.

Ainda segundo os mesmos autores, no ano de 2011 foram registradas 1.051 mortes por incêndio ou inalação de fumaça no Brasil pelo sistema de informações sobre mortalidade do SUS, enquanto o Japão teve 1.750 mortes com as mesmas causas e os Estados Unidos tiveram 3.192 .

Conforme os dados do CTIF (2016) Report n. 21, as perdas diretas em razão de incêndio entre os anos de 2008 e 2010 foram em média 0,12\% do Produto Interno Bruto dos países analisados, chegando a 0,2\% para a França. Dentre as cidades analisadas nota-se certa tendência do maior número de mortes por incêndio ser em locais com grande densidade demográfica. Esse relatório não possui nenhum dado relacionado ao Brasil, indicando a falta 
de estatística nacional. Entretanto, após os grandes incêndios na década de 1970, houve uma maior preocupação relacionada às medidas contra incêndio.

A resistência ao fogo de uma estrutura está relacionada ao tempo em que ela é capaz de resistir às solicitações para as quais foi projetada, na situação de incêndio. Os edifícios devem ser concebidos de modo que, em caso de incêndio, os ocupantes possam abandoná-lo em segurança ou serem socorridos.

O Eurocode 6 Parte 1-2:2005 define alguns critérios de resistência da alvenaria de acordo com a sua finalidade:

- Isolamento térmico (I), o qual é considerado atendido quando em qualquer ponto da superfície não exposta ao fogo a variação de temperatura não exceda $180^{\circ} \mathrm{C}$ e a variação de temperatura média nesta mesma superfície não exceda $140^{\circ} \mathrm{C}$;

- Resistência mecânica (R), o qual é satisfeito quando a função de suporte de carga é mantida na exposição ao fogo durante um determinado intervalo de tempo;

- Estanqueidade (E), quando não ocorrem rachaduras ou aberturas que permitam a passagem de chamas e gases através do elemento;

- Impacto mecânico (M), quando um elemento de separação vertical resistir a uma carga concentrada horizontal de características especificadas em EN 1363 Parte 2.

Os três primeiros critérios são considerados básicos para o dimensionamento de alvenaria estrutural em situação de incêndio. Porém, segundo Leite, Moreno Jr. e Torres (2016), no Brasil consideram-se apenas os critérios de estanqueidade e isolamento térmico, deixando para segundo plano a resistência mecânica. Isso é incorreto, pois a estrutura não deve vir ao colapso durante a fuga dos usuários. A desconsideração do critério $\mathrm{R}$ ocorre provavelmente pela falta de métodos normatizados de dimensionamento da alvenaria em situação de incêndio.

Neste trabalho, pretende-se analisar o comportamento de prismas constituídos por blocos de concreto submetidos a altas temperaturas, verificando os critérios de resistência mecânica, estanqueidade e isolamento térmico. 


\subsection{OBJETIVOS}

O principal objetivo deste trabalho é verificar o desempenho da alvenaria estrutural com blocos de concreto em situação de incêndio. Para isto têm-se os seguintes objetivos específicos:

- Simular o comportamento do bloco e prisma sem revestimento submetidos à compressão em temperatura ambiente;

- Realizar a simulação numérica do prisma comprimido e em situação de incêndio;

- Comparar os resultados com valores obtidos experimentalmente em trabalhos realizados por outros autores.

\subsection{JUSTIFICATIVA}

Apesar de apresentar algumas desvantagens, como a dificuldade de se alterar a arquitetura depois da construção do edifício e necessidade de mão-de-obra qualificada, o uso de alvenaria estrutural apresenta vantagens significativas se comparado a outros sistemas construtivos. Como exemplo tem-se a economia de fôrmas, significativa redução nos desperdícios e uso de revestimentos devido à melhor qualidade do serviço prestado, e redução do número de especialidades na obra.

Essas vantagens podem levar a uma economia significativa na construção de edifícios em alvenaria estrutural, dependendo de suas características. Além disso, a dificuldade na alteração da arquitetura pode ser contornada se houver um planejamento prévio durante a fase de projeto. Assim, este sistema construtivo é adequado ao Brasil, porém, poucas pesquisas nacionais foram feitas sobre o comportamento da alvenaria estrutural em situação de incêndio (LEITE; MORENO JR.; TORRES, 2016; MORENO JR.; MOLINA, 2012), e o país ainda não possui métodos normatizados de dimensionamento de alvenaria estrutural em situação de incêndio. As propriedades térmicas e mecânicas dos materiais que a compõem foram pouco estudadas sob temperaturas elevadas e carga aplicada.

Estruturas em dimensões naturais dificilmente são submetidas a ensaios laboratoriais, devido às limitações físicas dos equipamentos e gastos gerados com os mesmos. A resistência à compressão da alvenaria em temperatura ambiente pode ser estimada através da compressão de prismas. Além disso, a transferência de calor em uma parede de separação pode ser simulada por meio de um prisma devido ao fluxo térmico ocorrer transversalmente aos 
elementos, e por meio de simulações termomecânicas é possível representar a deterioração térmica dos materiais, justificando o emprego de prismas no presente trabalho.

\subsection{METODOLOGIA}

As simulações numéricas foram realizadas no software Abaqus/CAE 6.14. Realizouse a modelagem do bloco de concreto e prisma de três blocos com argamassamento parcial submetido à compressão em temperatura ambiente com propriedades disponíveis em Oliveira (2014). Após ser validado o comportamento mecânico dos materiais, prosseguiram-se as simulações com o prisma de dois blocos e argamassamento total conforme especifica a ABNT NBR 16522:2016.

Por meio da revisão bibliográfica, foram encontrados resultados experimentais e numéricos da alvenaria composta por blocos cerâmicos submetida a elevadas temperaturas em Rosemann (2011). Para adquirir-se conhecimento sobre a simulação térmica e validar as propriedades térmicas da argamassa, simulou-se o comportamento da alvenaria constituída por blocos cerâmicos sem e com revestimento em argamassa em elevadas temperaturas.

A empresa Glasser, antiga Tecprem, forneceu um ensaio de resistência ao fogo em parede constituída por blocos de concreto sem função estrutural e com revestimento em apenas uma face, disponível em Oliveira e Berto (2015), que possibilitou a validação da simulação térmica. Então, para a comparação de resultados, simulou-se um prisma com revestimento em uma face e em situação de incêndio. As propriedades térmicas do bloco de concreto foram adotadas conforme a literatura técnica.

Depois de validadas as propriedades térmicas do bloco, modelou-se o prisma sem revestimento em elevadas temperaturas para a inserção dos resultados na simulação termomecânica. A perda de resistência mecânica com a elevação de temperatura foi adotada também conforme a literatura técnica e as condições de contorno foram variadas. Outra variação feita foi a adição de revestimento em argamassa nas duas faces do prisma nas simulações térmicas. 


\subsection{ORGANIZAÇÃO DO TRABALHO}

No Capítulo 1 foi apresentada uma breve introdução sobre o tema, seguida dos objetivos, justificativa e um resumo da metodologia empregada no trabalho.

O Capítulo 2 apresenta uma revisão bibliográfica sobre a alvenaria estrutural em temperatura ambiente e em situação de incêndio. São apresentadas definições de incêndio e incêndio-padrão, métodos de propagação de calor e algumas informações necessárias à simulação numérica. Foram estudadas as propriedades mecânicas e térmicas dos principais constituintes da alvenaria estrutural e apresentados alguns estudos sobre a alvenaria estrutural em situação de incêndio.

No Capítulo 3 são descritas as simulações de compressão em temperatura ambiente do bloco de concreto e prismas.

No Capítulo 4 são apresentadas as simulações térmicas, inicialmente da alvenaria composta por blocos cerâmicos e em seguida, dos prismas constituídos por blocos de concreto.

As simulações termomecânicas são descritas no Capítulo 5 e no Capítulo 6 é feita uma discussão sobre os resultados. Por fim, as conclusões são apresentadas no Capítulo 7. 


\section{REVISÃO BIBLIOGRÁFICA}

\subsection{BREVE HISTÓRICO SOBRE ALVENARIA ESTRUTURAL}

A alvenaria estrutural é um dos sistemas construtivos mais antigos da humanidade. Uma mistura de argila, areia, mais um agente estabilizante tem sido utilizado em construções habitacionais desde os primeiros registros históricos. De acordo com Schneider e Dickey (1994) o material pode ser encontrado nas antigas obras gregas e romanas. As ruínas de Tiro e Nínive mostram a sua utilização, assim como antigas cidades do Oriente Médio.

Segundo os mesmos autores, o uso de alvenaria de tijolo simples foi feito por egípcios, romanos e gregos. Como exemplo tem-se a pirâmide de Quéops no Egito, com aproximadamente 145 metros de altura e cerca de 2,3 milhões de blocos de rochas. A Pont du Gard, foi construída pelos romanos no sul da França em três níveis e estrutura em arco utilizando-se pedras.

O Farol de Alexandria, de acordo com Ramalho e Corrêa (2003), foi construído aproximadamente 280 anos antes de Cristo, possuía $134 \mathrm{~m}$ de altura e um engenhoso sistema de iluminação para guiar os navegantes do mar Mediterrâneo. Durou mais de 1500 anos e foi destruído por um terremoto no século XIV.

Conforme Oliveira Jr. (1992), a alvenaria estrutural foi utilizada em castelos e catedrais na Idade Média onde as paredes tinham espessuras variando entre 2 e 2,5 m. Nessa época, devido ao desconhecimento do comportamento resistente dos materiais e a falta de métodos racionais de cálculo, o dimensionamento era feito de forma empírica baseado na experiência adquirida pelos construtores.

De acordo com Schneider e Dickey (1994), por volta de 1920 se iniciaram os estudos e experimentos com alvenaria. Havia discussões e um reconhecimento esporádico da necessidade e dos benefícios da alvenaria armada. Depois do terremoto em março de $1933 \mathrm{em}$ Long Beach, a norma do Estado da Califórnia tornou obrigatório o uso de alvenaria armada na região da Costa do Pacífico para resistir aos sismos.

Até a metade do século XX, com a evolução dos procedimentos de cálculo e desenvolvimento técnico do metal, as estruturas em aço e em concreto armado se tornaram predominantes nas grandes obras devido à possibilidade de utilização de elementos com 
maior esbeltez enquanto a alvenaria estrutural destinou-se preponderantemente a obras de pequeno porte, segundo Oliveira Jr. (1992).

Conforme Cavalheiro (2009), por volta de 1950 o sistema construtivo em alvenaria estrutural ganhou novo impulso com o desenvolvimento de normas principalmente na Suíça. Assim, tornou-se possível determinar a resistência da alvenaria e a espessura necessária das paredes, surgindo prédios altos com este sistema construtivo.

Com o avanço científico sobre alvenaria estrutural, edifícios como o Monadnock construído em 1890 em Chicago, com 65 m de altura e paredes da base com espessura de 1,80 m aproximadamente, deixaram de ser construídos, surgindo edifícios com paredes mais esbeltas. Conforme Schneider e Dickey (1994), com o uso de técnicas modernas de construção, a espessura necessária seria inferior a $30 \mathrm{~cm}$.

No Brasil, de acordo com Oliveira Jr. (1992), em 1966 surgiram os primeiros edifícios em alvenaria armada, construídos em São Paulo com blocos vazados de concreto e quatro pavimentos. Em 1972 foi erguido um edifício com quatro torres e doze pavimentos, o condomínio Central Parque Lapa, também em alvenaria armada e blocos de concreto. Somente a partir de 1980, com a empresa Cerâmica Igaçaba S. A., que os blocos cerâmicos passaram a ser fabricados em escala industrial.

A propagação desse sistema construtivo no país a princípio se mostrou de forma lenta e restrita. Isso ocorreu devido ao maior domínio das técnicas de construção e projeto em concreto armado e à carência de informações sobre o tema em questão durante a formação dos profissionais nas universidades. Além disso, a maioria das pesquisas desenvolvidas eram estrangeiras e voltadas para os materiais e particularidades da região de origem.

Entretanto essa situação se alterou de forma significativa com o desenvolvimento de normas brasileiras e estudos sobre dimensionamento de elementos em alvenaria estrutural. Conforme Ramalho e Corrêa (2003) a preocupação com os custos acelerou as pesquisas, impulsionando este sistema construtivo, já que se mostrou uma opção econômica e eficiente para construção de edificações industriais e residenciais. 


\subsection{CARACTERÍSTICAS DOS PRINCIPAIS COMPONETES DA ALVENARIA ESTRUTURAL}

A Alvenaria estrutural é formada por blocos normalmente vazados, unidos por juntas de argamassa, dimensionada para suportar cargas além de seu peso próprio. Exerce função de vedação além de agir como elemento estrutural, e apresenta resistência à compressão elevada se comparada à resistência à tração.

Segundo a ABNT NBR 15812:2010, os elementos de alvenaria podem ser definidos conforme a função desempenhada pelas armaduras em:

- Não armado - elemento no qual a armadura não é considerada para resistir aos esforços solicitantes;

- Armado - quando armaduras passivas são consideradas para resistir aos esforços solicitantes;

- Protendida - quando o elemento possui armaduras ativas, ou seja, tensionadas.

Os principais componentes da alvenaria estrutural são: unidades cerâmicas, de concreto, ou sílico-calcárias, argamassa, graute e armaduras. A resistência do bloco será sempre maior que a resistência do prisma que por sua vez, será sempre maior que a resistência da parede, pois a adição de juntas tende a reduzir a sua resistência.

As unidades são as principais responsáveis pela resistência à compressão do elemento. São denominadas perfuradas as unidades que possuem furos verticais distribuídos na sua face de assentamento com porcentagem de vazios menor ou igual a $25 \%$ de sua área total, conforme a ABNT NBR 15270-1:2017. Geralmente os blocos apresentam cerca de 50\% de área de vazios.

A presente revisão bibliográfica se restringe ao estudo da alvenaria estrutural composta por blocos cerâmicos e de concreto, não armada e não grauteada.

\subsubsection{Bloco cerâmico}

A ABNT NBR 15270-1:2017 classifica as unidades cerâmicas como blocos ou tijolos de vedação ou estrutural, conforme sua geometria e sua resistência característica mínima em quilograma-força por centímetro quadrado referente à área bruta. A menor classe permitida para bloco estrutural é 40, correspondente à resistência característica mínima (f $\mathrm{bk}$ 
mínima) de $40 \mathrm{kgf} / \mathrm{cm}^{2}$ ou $4 \mathrm{MPa}$. A absorção d'água deve estar entre 8 e 21\% para todas as classes de bloco estrutural.

Segundo Ramalho e Corrêa (2003) paredes constituídas por blocos cerâmicos possuem eficiência parede-bloco inferior àquelas constituídas por blocos de concreto. Os autores destacam que quanto maior a resistência do bloco, maior será a resistência da alvenaria, porém, a eficiência será menor. A eficiência também varia de acordo com a forma do bloco e seu material constituinte. Na Tabela 1 constam as eficiências parede-bloco $\left(f_{\text {par }} / f_{b}\right)$ e prisma-bloco $\left(\mathrm{f}_{\mathrm{p}} / \mathrm{f}_{\mathrm{b}}\right)$ para o material cerâmico.

Tabela 1 - Valores de eficiência para o material cerâmico

\begin{tabular}{ccc}
\hline Eficiência & Valor mínimo & Valor máximo \\
\hline$\frac{f_{\text {par }}}{f_{b}}$ & 0,2 & 0,5 \\
$\frac{f_{p}}{f_{h}}$ & 0,3 & 0,6 \\
\hline
\end{tabular}

Fonte: Ramalho e Corrêa (2003)

A resistência à compressão da parede pode ser estimada por meio de ensaio de compressão axial de prismas ou pequenas paredes, quando esses são concebidos com as mesmas condições em que foi executada a parede. Segundo a ABNT NBR 15812-1:2010 e a ABNT NBR 15961-1:2011 a resistência característica à compressão simples da alvenaria constituída por blocos cerâmicos ou de concreto é cerca de $70 \%$ da resistência característica à compressão simples de prisma $\left(f_{\mathrm{pk}}\right)$ e $85 \%$ de pequena parede $\left(\mathrm{f}_{\mathrm{ppk}}\right)$.

O coeficiente de Poisson da alvenaria composta por blocos cerâmicos é 0,15 e módulo de elasticidade pode ser adotado como 600 vezes a resistência característica do prisma e no máximo 12 GPa, de acordo com a ABNT NBR 15812-1:2010.

Conforme Drysdale, Hamid e Baker (1994) a resistência à tração das unidades cerâmicas é cerca de $10 \%$ da resistência à compressão e o tipo de ensaio realizado exerce grande influência nesse valor. A tração na flexão gera resultados de 20 a 50\% maiores que a tração por compressão diametral, como pode ser visto na Figura 3. 
Figura 3 - Razão entre resistência à tração e compressão para unidades cerâmicas

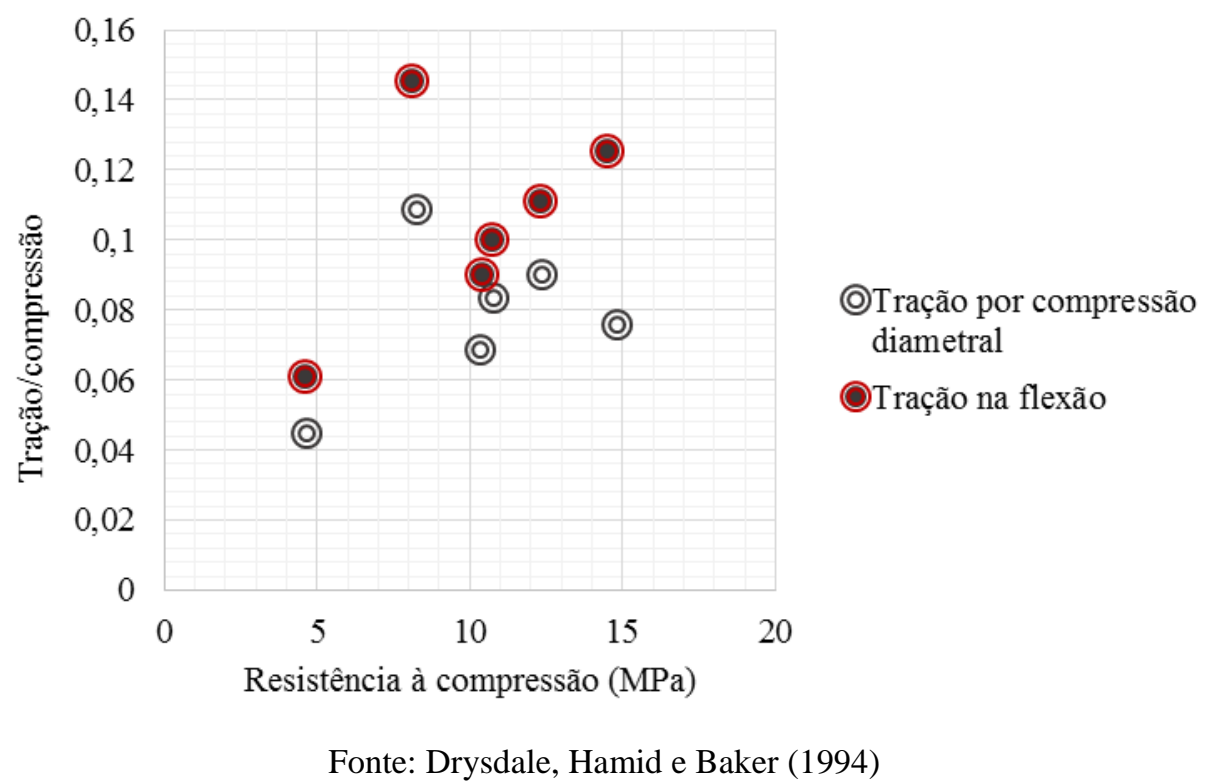

\subsubsection{Bloco de concreto}

A ABNT NBR 6136:2016 classifica os blocos de concreto conforme seu uso, a sua resistência característica à compressão axial aos 28 dias em relação à área bruta e limita a absorção e retração linear por secagem, conforme indicado na Tabela 2:

Tabela 2 - Requisitos para resistência característica do bloco à compressão, absorção e retração

\begin{tabular}{|c|c|c|c|c|c|c|c|}
\hline \multirow{3}{*}{ Classificação } & \multirow{3}{*}{ Classe } & \multirow{3}{*}{$\begin{array}{c}\text { Resistência } \\
\text { característica à } \\
\text { compressão axial } \\
(\mathrm{MPa})\end{array}$} & \multicolumn{4}{|c|}{$\begin{array}{c}\text { Absorção } \\
(\%)\end{array}$} & \multirow{3}{*}{$\begin{array}{c}\text { Retração } \\
(\%)\end{array}$} \\
\hline & & & \multicolumn{2}{|c|}{ Agregado normal } & \multicolumn{2}{|c|}{ Agregado leve } & \\
\hline & & & Individual & Média & Individual & Média & \\
\hline \multirow{2}{*}{$\begin{array}{c}\text { Com função } \\
\text { estrutural }\end{array}$} & A & $\mathrm{f}_{\mathrm{bk}} \geq 8,0$ & $\leq 9,0$ & $\leq 8,0$ & \multirow[b]{3}{*}{$\leq 16,0$} & \multirow[b]{3}{*}{$\leq 13,0$} & \multirow[b]{3}{*}{$\leq 0,065$} \\
\hline & B & $4,0 \leq \mathrm{f}_{\mathrm{bk}}<8,0$ & $\leq 10,0$ & $\leq 9,0$ & & & \\
\hline $\begin{array}{l}\text { Com ou sem } \\
\text { função } \\
\text { estrutural }\end{array}$ & $\mathrm{C}$ & $f_{b k} \geq 3,0$ & $\leq 11,0$ & $\leq 10,0$ & & & \\
\hline
\end{tabular}

Fonte: ABNT NBR 6136:2016

Na Tabela 3 constam as eficiências parede-bloco $\left(f_{p a r} / f_{b}\right)$ e prisma-bloco $\left(f_{p} / f_{b}\right)$ para os elementos estruturais feitos com blocos de concreto. 
Tabela 3 - Valores de eficiência para blocos de concreto

\begin{tabular}{ccc}
\hline Eficiência & Valor mínimo & Valor máximo \\
\hline$\frac{f_{p a r}}{f_{b}}$ & 0,4 & 0,6 \\
$\frac{f_{p}}{f_{b}}$ & 0,5 & 0,9 \\
\hline
\end{tabular}

Fonte: Ramalho e Corrêa (2003)

O diagrama tensão deformação do bloco é uma ferramenta importante para a definição do mecanismo de falha da alvenaria. Segundo Drysdale, Hamid e Baker (1994) o formato deste diagrama para bloco de concreto submetido à compressão uniaxial é similar ao concreto. A não-linearidade começa geralmente entre 35 e $50 \%$ de sua resistência à compressão e a configuração da curva depende do confinamento gerado pela placa da prensa que comprime o bloco.

Conforme a ABNT NBR 15961-1:2011 o coeficiente de Poisson para a alvenaria composta por blocos de concreto é 0,2 e o módulo de elasticidade pode ser adotado como 800 vezes a resistência característica à compressão do prisma. De acordo com Drysdale, Hamid e Baker (1994) o módulo de elasticidade encontra-se aproximadamente entre 500 e 1000 vezes a resistência à compressão do bloco e a resistência à tração é cerca de $10 \%$ da resistência à compressão, conforme ilustra a Figura 4.

Figura 4 - Razão entre resistência à tração e compressão para blocos de concreto

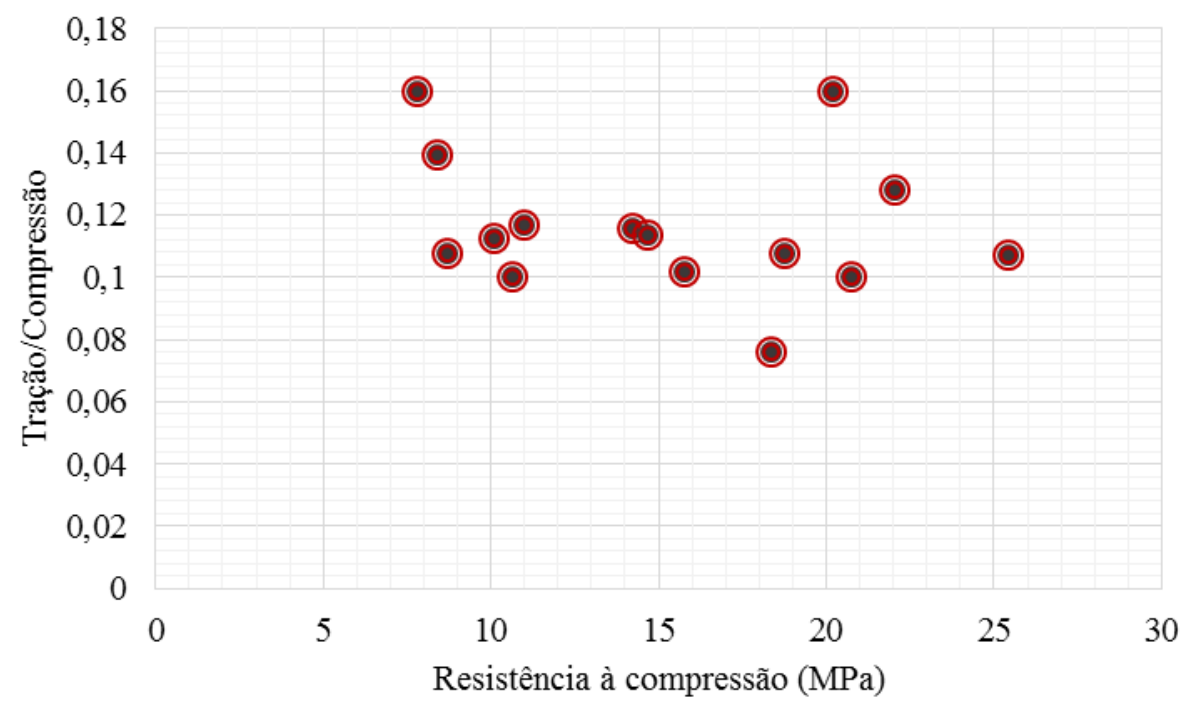

Fonte: Adaptado de Drysdale, Hamid e Baker (1994) 


\subsubsection{Argamassa}

A argamassa possui as funções de unir os blocos, absorver pequenas deformações, transmitir e uniformizar as tensões. Para um bom desempenho de suas finalidades, a argamassa deve ser durável, apresentar boa trabalhabilidade, plasticidade e resistência. Entretanto, segundo Ramalho e Corrêa (2003) a resistência à compressão da argamassa não é o principal fator responsável pela resistência à compressão das paredes de alvenaria.

Geralmente, a argamassa é composta de cimento, areia, cal e água. A resistência à compressão é bastante influenciada pela quantidade de cimento na mistura, enquanto a cal contribui com a retenção de água e trabalhabilidade, conforme ilustrado na Figura 5.

Figura 5 - Relação da composição da argamassa com a resistência à compressão e a retenção de água

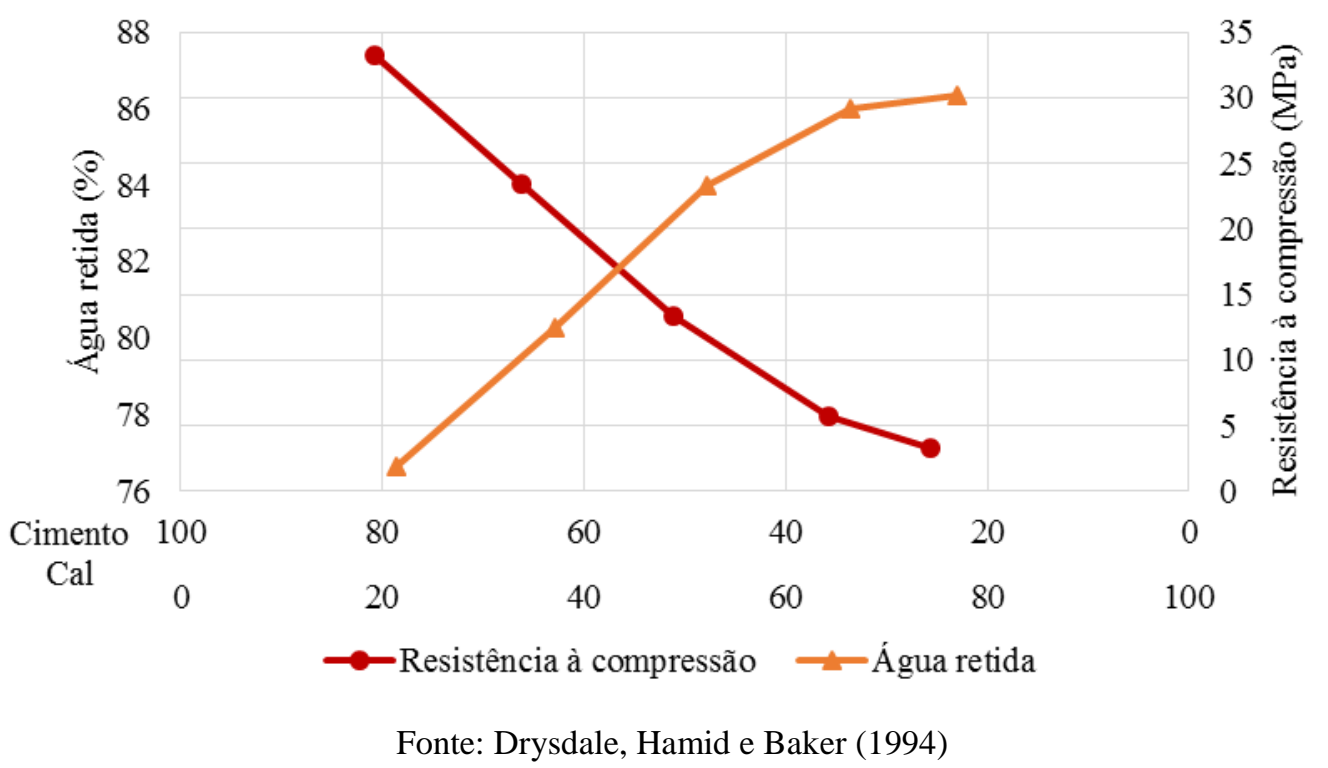

A união entre a argamassa e o bloco se dá devido à ligação mecânica e possivelmente devido à aderência química, conforme Drysdale, Hamid e Baker (1994). Em virtude de as juntas de argamassa apresentarem pequena espessura comparada às dimensões do bloco, existe um confinamento que a torna menos vulnerável à ruptura, mesmo quando possui resistência à compressão uniaxial relativamente baixa.

Assim, de acordo com Ramalho e Corrêa (2003), somente se a argamassa apresentar resistência à compressão cerca de 30\% menor que a resistência do bloco referente à área bruta, que essa poderá exercer importante influência na resistência à compressão da parede. 
Segundo Drysdale, Hamid e Baker (1994), um aumento de $100 \%$ na resistência à compressão da argamassa levará ao aumento de apenas $10 \%$ da resistência à compressão da parede. Os autores não recomendam o uso de argamassa mais resistente do que o necessário, pois a função de absorver pequenas movimentações diferenciais ficaria comprometida.

Ramalho e Corrêa (2003) afirmam que argamassas com alta resistência pode reduzir a resistência final da parede. A ABNT NBR 15812-1:2010 restringe a resistência à compressão da argamassa ao valor mínimo de 1,5 MPa e ao máximo de $70 \%$ da resistência característica do bloco em relação à área líquida.

Buttler et al. (2006) analisaram as propriedades da argamassa do tipo (ii) com o traço em volume de 1:1:6, sendo cimento : cal : areia, e relação água/cimento de 1,35 em contato com elementos de diferentes absortividades: a argamassa de referência (1) produzida diretamente nas formas metálicas, argamassa (2) em contato com faces de blocos com 4,5 $\mathrm{MPa}$ de resistência e argamassa (3) em contato com blocos de $12 \mathrm{MPa}$. Na Tabela 4 estão contidas algumas das propriedades avaliadas por Buttler et al. (2006) além da relação entre resistência à tração e compressão.

Tabela 4 - Propriedades mecânicas da argamassa

\begin{tabular}{ccccccc}
\hline Argamassa & $\begin{array}{c}\text { Idade } \\
(\text { dias })\end{array}$ & $\begin{array}{c}\text { Massa } \\
\text { específica } \\
\text { seca } \\
\left(\mathrm{kg} / \mathrm{m}^{3}\right)\end{array}$ & $\begin{array}{c}\text { Resistência } \\
\text { à } \\
\text { compressão } \\
(\mathrm{MPa})\end{array}$ & $\begin{array}{c}\text { Resistência à } \\
\text { tração por } \\
\text { compressão } \\
\text { diametral } \\
(\mathrm{MPa})\end{array}$ & $\begin{array}{c}\text { Relação } \\
\text { resistência à } \\
\text { tração/resistência } \\
\text { à compressão }\end{array}$ & $\begin{array}{c}\text { Módulo } \\
\text { de } \\
\text { elasticidade } \\
(\mathrm{GPa})\end{array}$ \\
\hline \multirow{2}{*}{1} & 7 & 1850 & 4,73 & 0,58 & 0,12 & 6,23 \\
& 28 & 1895 & 5,81 & 0,65 & 0,11 & 7,30 \\
2 & 7 & 1935 & 5,60 & 0,87 & 0,16 & 6,35 \\
& 28 & 1937 & 7,54 & 1,02 & 0,14 & 10,83 \\
& 7 & 1888 & 6,21 & 0,69 & 0,11 & 8,86 \\
& 28 & 1922 & 7,22 & 0,91 & 0,13 & 9,22 \\
\hline
\end{tabular}

Fonte: Adaptado de Buttler et al. (2006)

\subsection{INCÊNDIO}

O fogo, segundo a National Fire Protection Association - NFPA (2016), é um processo de oxidação que ocorre de forma rápida emitindo luz, fumaça e calor, causando elevação de temperatura. Para a manutenção do fogo é necessário que haja combustível para ser queimado, comburente (oxigênio), calor e a reação em cadeia. Essa reação em cadeia faz 
com que o calor gerado na combustão seja reutilizado, dando continuidade ao processo. $\mathrm{Na}$ Figura 6 são apresentados os componentes essenciais para a ocorrência do fogo.

Figura 6 - Tetraedro do fogo

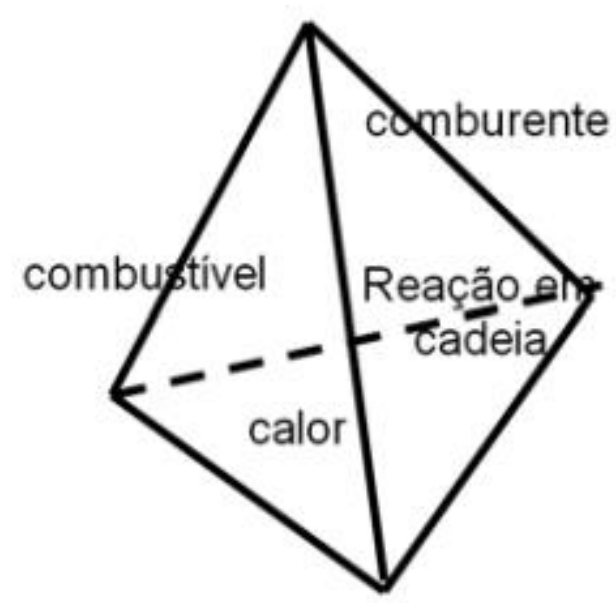

Fonte: Seito et al. (2008)

O incêndio, conforme a ABNT NBR 13860:1997, é o fogo fora de controle. Segundo a NFPA (2016) o incêndio apresenta quatro fases:

- Pré-ignição: quando combustível, calor e oxigênio se juntam em uma reação química elevando a temperatura de forma lenta;

- Crescimento do fogo: após o surgimento da primeira chama que serve de fonte de calor, o combustível adicional inflama e a chama se espalha pelo ambiente por meio de objetos próximos ou atinge o teto da edificação;

- Incêndio desenvolvido: quando o fogo já se espalhou por todo ou quase todo material combustível disponível, as temperaturas atingem seu pico causando danos em elementos estruturais e o oxigênio é consumido rapidamente;

- Extinção: ocorre caso o incêndio continue e o combustível seja totalmente consumido. A diminuição das chamas provoca a diminuição da temperatura.

A Figura 7 ilustra as fases de um incêndio real com a elevação de temperatura de acordo com o tempo. 
Figura 7 - Fases de um incêndio real

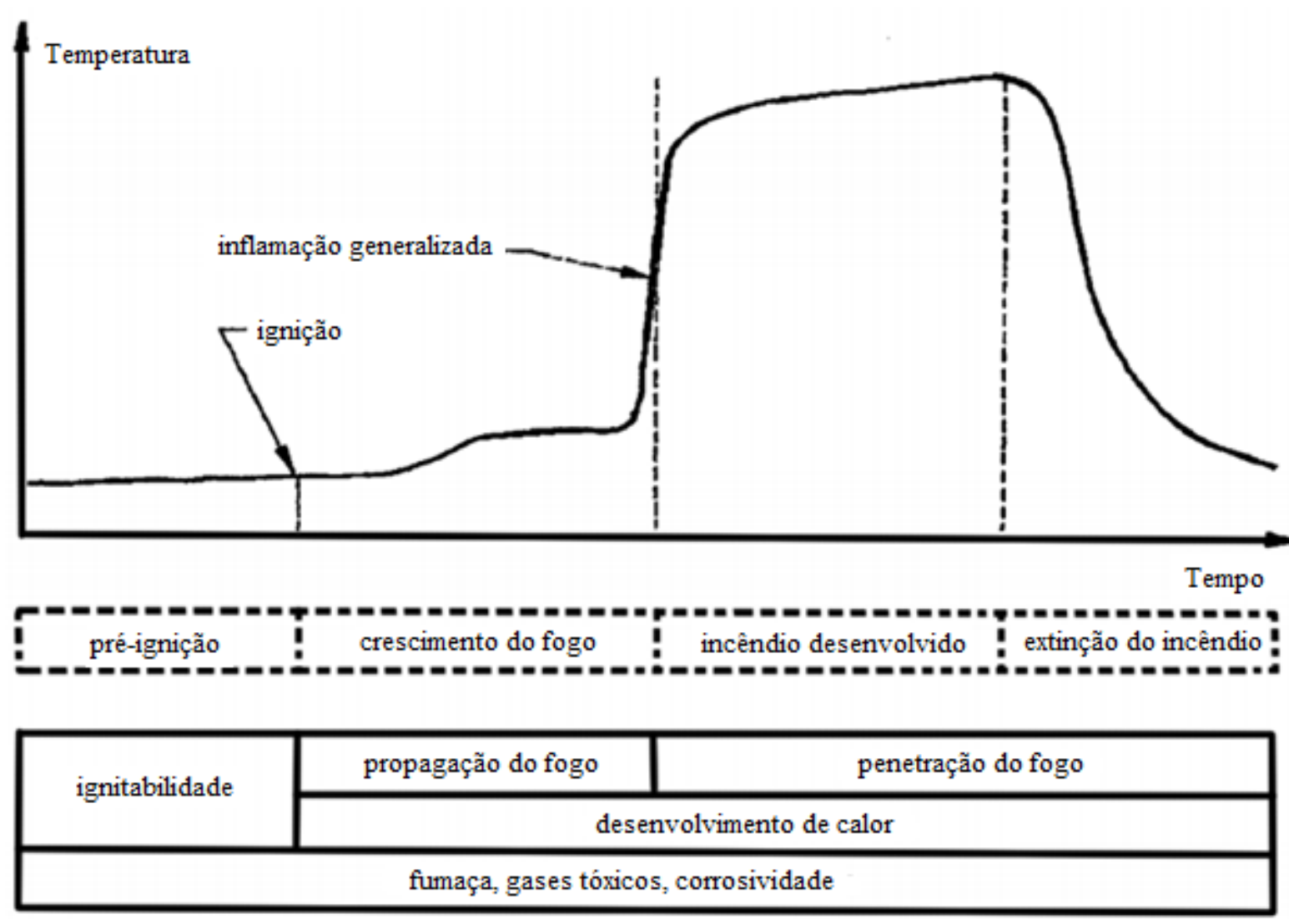

Fonte: adaptado de Seito et al. (2008)

Conforme Costa e Silva (2006) o desenvolvimento do incêndio depende de diversos fatores, tais como:

- Carga de incêndio - correspondente a todo material combustível presente no local do incêndio;

- Grau de ventilação - de certa forma representa a quantidade de comburente do local. Quanto maior o fator de abertura mais rápida é a combustão, mais elevada é a temperatura máxima e menor é a duração do incêndio, pois o combustível é consumido mais rapidamente;

- Características dos materiais da compartimentação - a propagação do fogo faz com que ocorra a diminuição da temperatura máxima do incêndio no compartimento onde se iniciou, porque ocorre uma menor duração das chamas. Então, maior será a temperatura máxima do incêndio quando os materiais da compartimentação forem mais resistentes à ação do fogo. 
Estes fatores que caracterizam o incêndio podem ser combinados de diversas formas. Portanto, cada incêndio é único e para possibilitar a análise e comparação de resultados experimentais é necessária a padronização dos procedimentos.

\subsubsection{Incêndio-padrão}

Para a execução de experimentos é preciso definir a elevação de temperatura do forno em relação ao tempo de ensaio. Segundo Moreno Jr. e Molina (2012), a Curva-padrão sugerida pela International Organization for Standardization - ISO 834-1:1999 é a mais utilizada no Brasil e internacionalmente. Nessa curva é considerado o material combustível celulósico.

A ABNT NBR 5628:2001 estabelece medidas a serem tomadas durante um ensaio de determinação de resistência ao fogo de alguns elementos estruturais, incluindo paredes de alvenaria estrutural. Nesta norma é recomendada a mesma curva-padrão temperatura-tempo que a sugerida pela ISO 834-1:1999, dada pela Equação 1:

$\mathrm{T}-\mathrm{T}_{0}=345 \log (8 \mathrm{t}+1)$

onde:

té o tempo em minutos;

$\mathrm{T}_{0}$ é a temperatura inicial do ambiente em graus Celsius;

T é a temperatura do forno em graus Celsius no instante de tempo t.

O Eurocode 1 Parte 1-2:2002 apresenta a curva temperatura-tempo denominada Curva $\mathrm{H}$ para hidrocarbonetos como material combustível com temperatura máxima de $1100^{\circ} \mathrm{C}$, conforme a Equação 2:

$\mathrm{T}=1080\left(1-0,325 \mathrm{e}^{-0,167 t}-0,675 \mathrm{e}^{-2,5 t}\right)+\mathrm{T}_{0}$

A American Society for Testing and Materials - ASTM E119:2000 sugere outra curva temperatura-tempo com valores semelhantes aos indicados pela ISO 834-1:1999. Na Figura 8 são apresentadas as curvas temperatura-tempo obtidas através das Equações 1 e 2 com temperatura inicial de $20^{\circ} \mathrm{C}$ e valores disponíveis na ASTM E119:2000. 
Figura 8 - Curvas padronizadas para incêndio

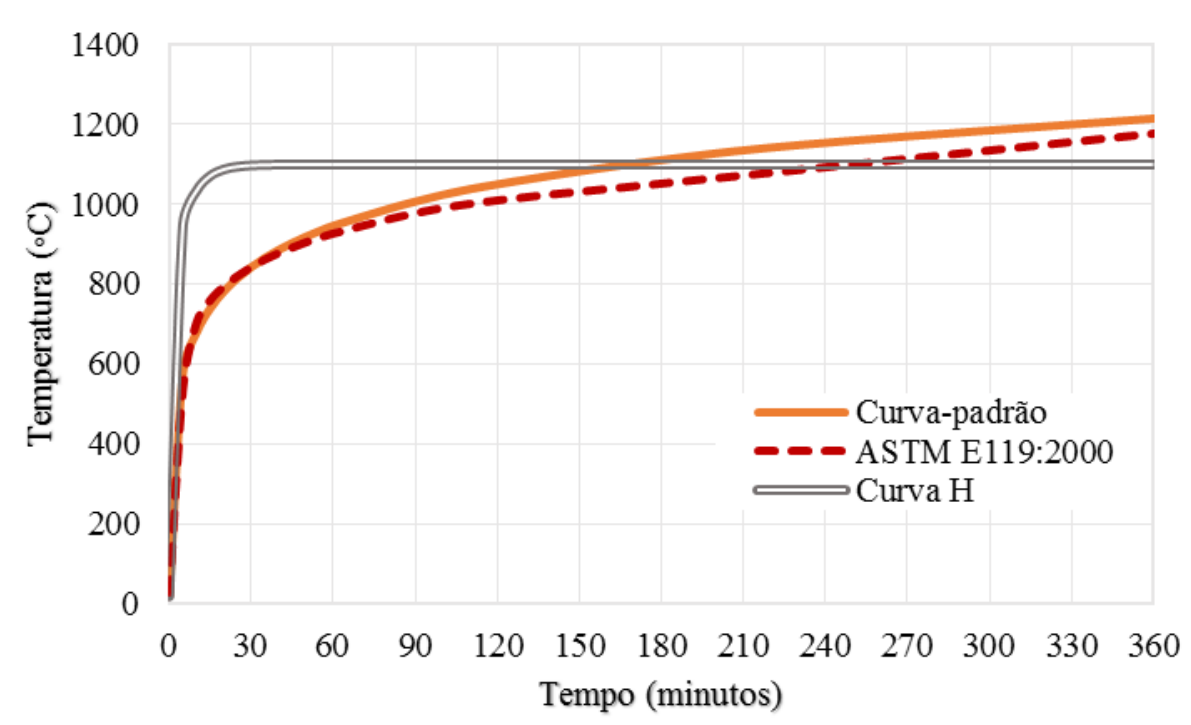

Nota-se através da Figura 8 que no incêndio padrão não é considerada a fase de extinção natural, na qual ocorreria o resfriamento da estrutura. Apesar da Curva-padrão não retratar uma real situação, ela apresenta o período mais intenso de queima de um incêndio, com o contínuo fornecimento de material combustível para o forno.

\subsubsection{Tempo requerido de resistência ao fogo}

Em elevadas temperaturas, os materiais estruturais geralmente têm as suas propriedades mecânicas alteradas, perdendo parcial ou totalmente a capacidade de resistir aos esforços para as quais foram projetadas.

O tempo de resistência ao fogo das edificações é definido de acordo com a sua utilização, para que em caso de incêndio seja possível a fuga dos ocupantes em segurança, seja garantida também a segurança das equipes de combate ao incêndio e minimizados os danos a edifícios próximos, pela ABNT NBR 14432:2001.

Em Seito et al. (2008) o tempo requerido de resistência ao fogo (TRRF) é designado como o tempo mínimo em minutos que a estrutura deve resistir aos critérios de resistência ao fogo, quando aplicável, na situação de incêndio padronizada.

Conforme Silva (2008) o TRRF é o tempo em que o elemento estrutural atinge sua temperatura máxima equivalente a um incêndio natural com a curva de incêndio-padrão. $\mathrm{Na}$ Figura 9 é apresentado o conceito de TRRF ou tempo equivalente. 
Figura 9 - TRRF ou tempo equivalente

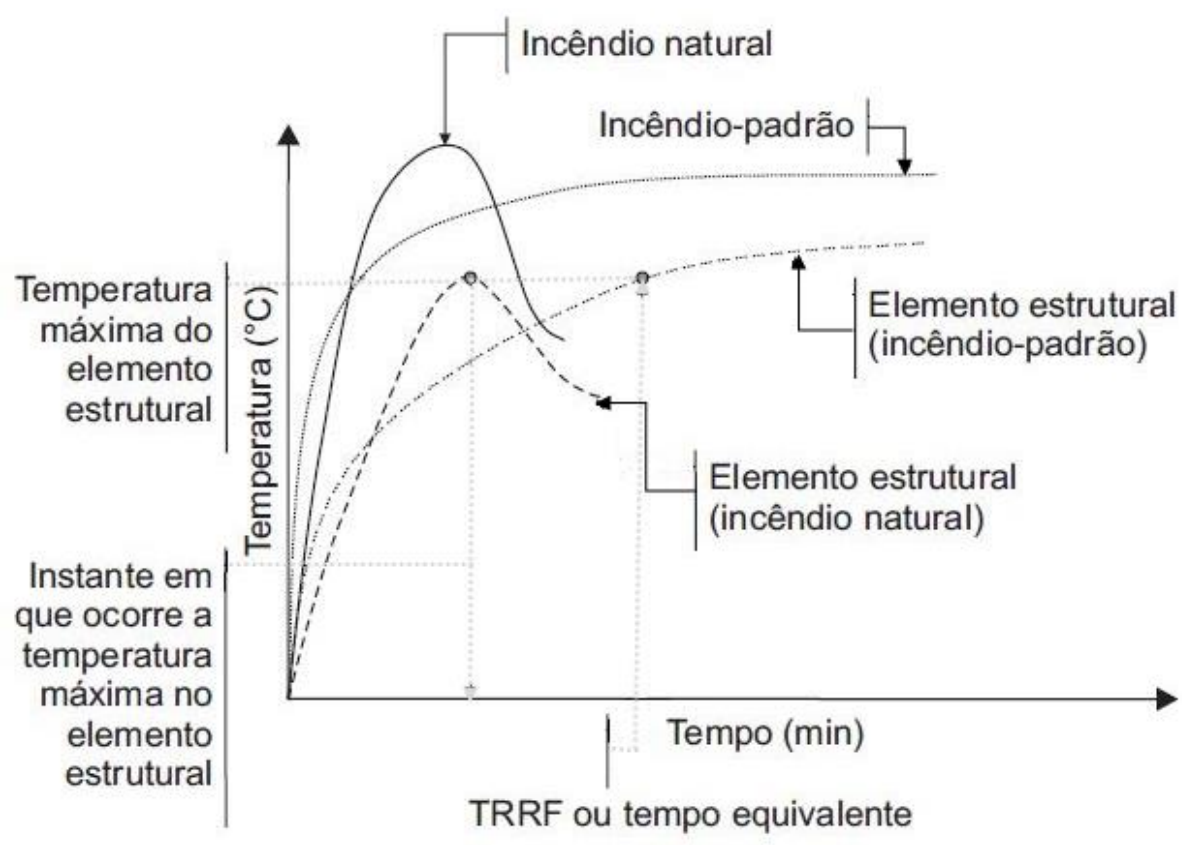

Fonte: Silva (2008)

\subsection{CALOR E MÉTODOS DE PROPAGAÇÃO}

Halliday, Resnick e Krane (1996) definem calor como a energia que flui devido à diferença de temperatura entre um elemento e sua vizinhança. A transmissão do calor pode acontecer de três diferentes formas: condução, convecção e radiação. Esses métodos de propagação podem agir simultânea ou separadamente. Na Figura 10 estão ilustrados os mecanismos de transferência de calor em um bloco de concreto. 
Figura 10 - Mecanismos de transferência de calor

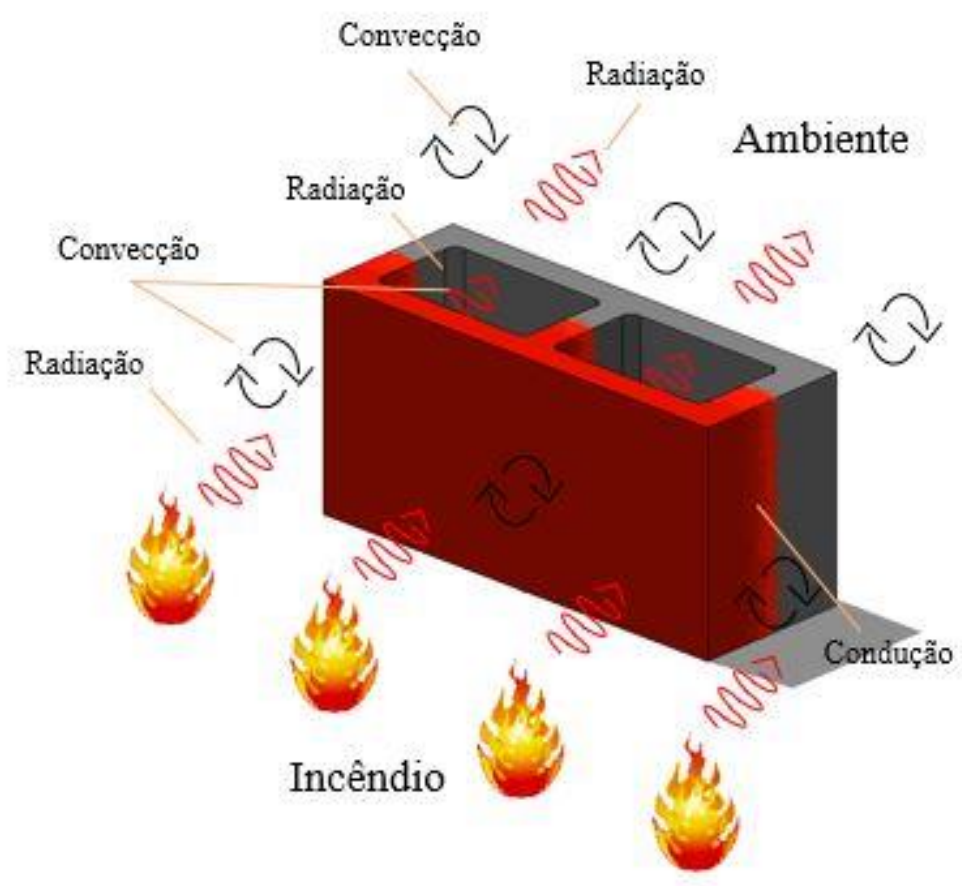

Fonte: Autora (2018)

Encontrar soluções analíticas para problemas de transferência de calor é quase impraticável, a não ser nos casos mais simples, de acordo com Wang (2002). Segundo o mesmo autor, em aplicações de segurança contra incêndio as questões sobre propagação de calor são resolvidas numérica ou experimentalmente.

\subsubsection{Condução}

Conforme Buchanan (2002) a condução é um mecanismo de transferência de calor que ocorre em materiais sólidos. Nos materiais considerados bons condutores a propagação do calor é feita por meio de interações envolvendo elétrons livres, assim, geralmente bons condutores de calor são também bons condutores de eletricidade. Nos materiais considerados maus condutores, o calor é transferido através de vibrações mecânicas da rede molecular.

Ainda segundo o mesmo autor, várias propriedades dos materiais interferem no cálculo da transferência de calor, como a massa específica, calor específico e condutividade térmica. Calor específico $\left(c_{p}\right)$ é a quantidade de calor necessária para elevar em um grau a temperatura da unidade de massa do material. A condutividade térmica $(k)$ representa a taxa 
de calor transferida através da unidade de espessura do material devido à diferença da unidade de temperatura.

Geralmente, materiais que possuem maior massa específica possuem condutividade térmica mais elevada. Conforme Rigão (2012) isso ocorre devido à compacidade da microestrutura do material. Quanto maior a massa específica menor será a quantidade de vazios, elevando a sua capacidade de condução de calor.

De acordo com Stancato (2000) a umidade é outra variável que influencia na condutividade. A presença de água nos poros do material faz com que ele conduza mais calor, uma vez que a condutividade térmica da água é maior que a do ar, 0,6 W/(m.K) e 0,025 $\mathrm{W} /(\mathrm{m} . \mathrm{K})$ respectivamente.

A difusividade térmica $(\alpha)$ em $\mathrm{m}^{2} / \mathrm{s}$ é definida através da Equação 3:

$\alpha=\frac{k}{\rho \cdot c_{p}}$

onde:

$k$ é a condutividade térmica em $\mathrm{W} /(\mathrm{m} . \mathrm{K})$;

$\rho$ é a massa específica em $\mathrm{kg} / \mathrm{m}^{3}$;

$c_{p}$ é o calor específico em $\mathrm{J} /(\mathrm{kg} . \mathrm{K})$.

A inércia térmica $i_{t}$, cuja unidade é $\mathrm{W}^{2} \cdot \mathrm{s} /\left(\mathrm{m}^{4} \mathrm{~K}^{2}\right)$, é definida pela Equação 4:

$i_{t}=k \cdot \rho \cdot c_{p}$

De acordo com Buchanan (2002) materiais que possuem baixa inércia térmica entram em ignição mais rapidamente que aqueles que possuem maior inércia térmica, pois quando esses são aquecidos, a temperatura da superfície exposta aumenta rapidamente. Assim, em caso de incêndio, locais que são forrados com materiais de baixa inércia térmica alcançarão temperaturas mais elevadas.

Segundo Drysdale (1998), o fluxo de calor ocorre quando se tem uma região com temperatura mais alta que outra. Este fluxo de calor unidimensional em $\mathrm{W} / \mathrm{m}^{2}$ é definido pela Equação 5 de Fourier:

$$
\stackrel{\mathrm{g}}{q^{\prime \prime} \mathrm{x}}=-k \frac{d T}{d x}
$$


onde:

$k$ é a condutividade térmica em $\mathrm{W} /(\mathrm{m} . \mathrm{K})$;

T é a temperatura em graus Celsius ou Kelvin;

$x$ é a distância na direção do fluxo de calor em metros.

A Figura 11 ilustra a condução de calor em um elemento com camadas de diversos materiais.

Figura 11 - Situação estacionária de condução em um elemento composto

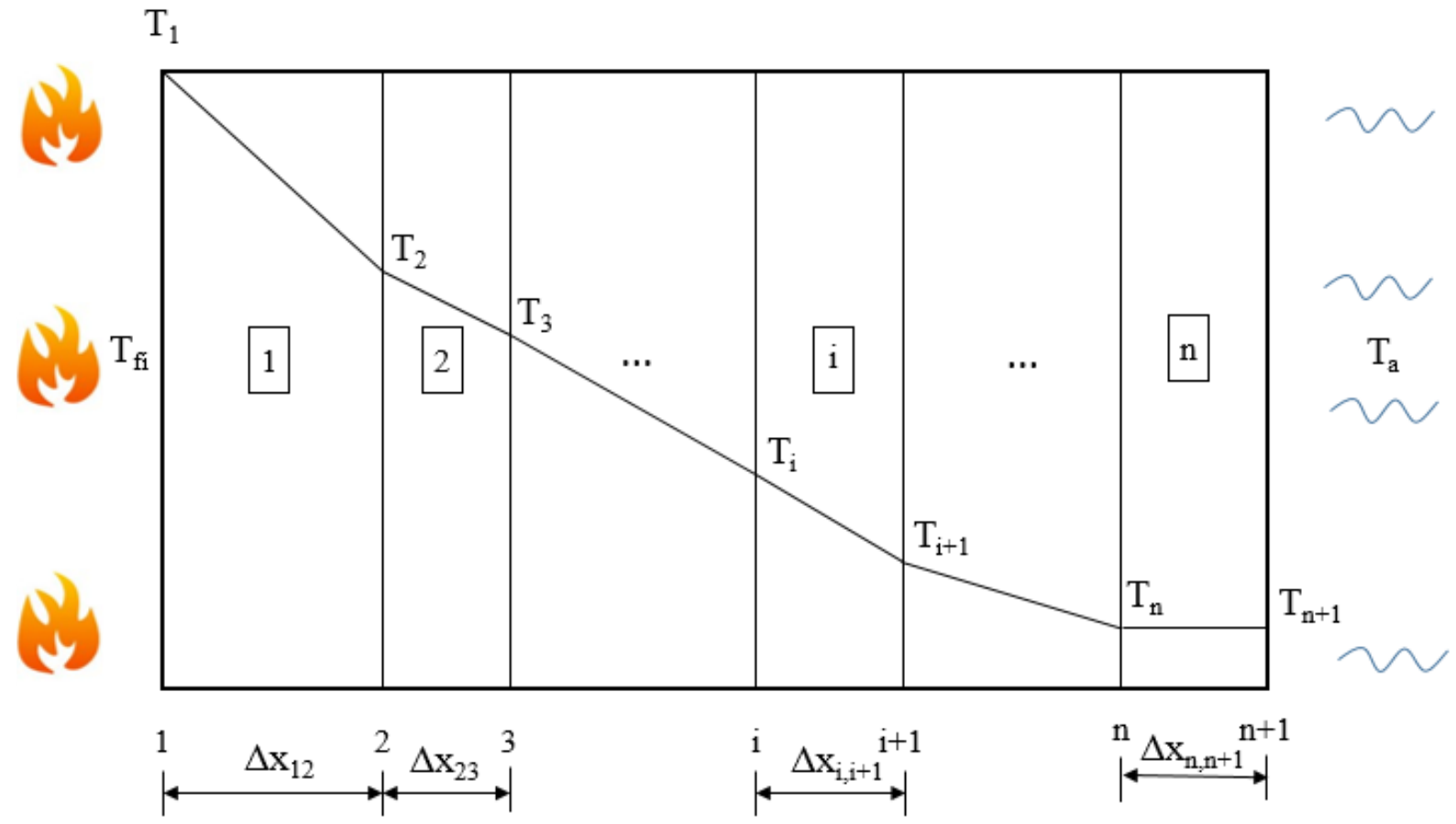

Fonte: Adaptado de Wang (2002)

Considerando a situação estacionária de condução, ou seja, quando a temperatura não varia com o tempo, de acordo com o princípio da conservação de energia a partir da Equação 5, pode-se escrever:

$$
\dot{\mathrm{q}}=-k_{12} \frac{T_{2}-T_{1}}{\Delta x_{12}}=-k_{23} \frac{T_{3}-T_{2}}{\Delta x_{23}}=\ldots-k_{i, i+1} \frac{T_{i+1}-T_{i}}{\Delta x_{i, i+1}} \ldots=-k_{n, n+1} \frac{T_{n+1}-T_{n}}{\Delta x_{n, n+1}}
$$

Reordenando a Equação 6, obtém-se: 


$$
\begin{aligned}
& T_{1}-T_{2}=\stackrel{\mathrm{g}}{\mathrm{q}^{\prime \prime}} \frac{\Delta x_{12}}{k_{12}}=\stackrel{\mathrm{g}}{\mathrm{q}^{\prime \prime}} R_{12} \\
& \cdots \\
& T_{i}-T_{i+1}=\stackrel{\mathrm{g}}{\mathrm{q}^{\prime \prime}} \frac{\Delta x_{i, i+1}}{k_{i, i+1}}=\stackrel{\mathrm{g}}{\mathrm{q}^{\prime \prime}} R_{i, i+1} \\
& \cdots \\
& T_{n}-T_{n+1}=\stackrel{\mathrm{g}}{\mathrm{q}} \frac{\Delta x_{n, n+1}}{k_{n, n+1}}=\stackrel{\mathrm{g}}{\mathrm{q}} R_{n, n+1}
\end{aligned}
$$

onde:

$k_{i, i+1}$ é a condutividade térmica do respectivo material;

$R_{i, i+1}=\frac{\Delta x_{i, i+1}}{k_{i, i+1}}$ representa a resistência térmica;

$T_{i}$ e $T_{i+1}$ são as temperaturas em cada face do material;

$\Delta x_{i, i+1}$ é a espessura.

Conforme Wang (2002), é possível resumir a Equação 7 em:

$$
T_{1}-T_{n, n+1}=\stackrel{\mathrm{g}}{\mathrm{q}} \sum_{i=1}^{n} R_{i, i+1}
$$

Em aplicações práticas de segurança contra incêndio é comum se conhecer a temperatura da face do elemento exposta às chamas e ser desconhecida a temperatura da face exposta ao ambiente. Para determinar a distribuição de temperatura no elemento, podem-se utilizar as condições de contorno, conforme sugere Wang (2002). Assume-se que a troca de calor entre o fluido e a superfície exposta ao fogo ilustrada na Figura 11 é devida à diferença de temperatura na interface, conforme indicado na Equação 9:

$$
\stackrel{\mathrm{g}}{q^{\prime \prime}}=h_{f i}\left(T_{f i}-T_{1}\right)
$$

E na face exposta à temperatura ambiente: 


$$
\stackrel{\mathrm{g}}{q^{\prime \prime}}=h_{a}\left(T_{n+1}-T_{a}\right)
$$

onde:

$h_{f i}$ é o coeficiente de transferência de calor no lado exposto ao fogo;

$h_{a}$ é o coeficiente de transferência de calor no lado exposto ao ambiente.

As Equações 9 e 10 podem ser reescritas da seguinte forma:

$$
\begin{aligned}
& \left(T_{f i}-T_{1}\right)=\mathrm{g} / h_{f i}=\stackrel{\mathrm{g}}{\mathrm{q}} R_{f} \\
& \left(T_{n+1}-T_{a}\right)=\stackrel{\mathrm{g}}{\mathrm{q}} / h_{a}=\mathrm{g} \\
& \mathrm{q}
\end{aligned}
$$

Combinando-se as Equações 8 e 11 obtém-se:

$T_{f i}-T_{a}=R \stackrel{\mathrm{g}}{\mathrm{q}^{\prime \prime}}$

onde:

$$
R=R_{f}+\sum_{i=1}^{n} R_{i, i+1}+R_{a}
$$

Na situação estacionária de condução não se considera o calor necessário para alterar a temperatura do material que está sendo aquecido ou resfriado. Já no fluxo transiente de calor, quando a temperatura varia com o tempo, deve-se considerar a quantidade de calor requerida para mudar a temperatura do material, de acordo com Buchanan (2002). Em materiais onde nenhum calor interno está sendo liberado, a transferência unidimensional de calor é regida pela Equação 13:

$$
\frac{\partial^{2} T}{\partial x^{2}}=\frac{1}{\alpha} \frac{\partial T}{\partial t}
$$

onde:

t é o tempo em segundos;

$\alpha$ é a difusividade térmica $\mathrm{em} \mathrm{m}^{2} / \mathrm{s}$. 
Nota-se que materiais com baixa difusividade térmica que tiverem a superfície submetida a elevadas temperaturas no regime transiente, conduzirão mais calor que materiais com alta difusividade térmica. Segundo Buchanan (2002) a equação de condução de calor pode ser resolvida usando métodos analíticos, numéricos ou gráficos, e pode ser estendida para duas ou três dimensões se necessário.

\subsubsection{Convecção}

A convecção é um método de propagação de calor devido ao movimento de fluidos, tanto gasosos quanto líquidos. Este mecanismo é um fator importante, pois de acordo com Drysdale (1998) a maior parte do calor liberado pela superfície em chamas é transportado através de movimentos convectivos na fase inicial do incêndio, e também é responsável pela sua evolução. Além disso, a fumaça e gases quentes são conduzidos ao teto ou para fora de um lugar em chamas devido à convecção.

Segundo Buchanan (2002) o cálculo do calor transferido pela convecção geralmente envolve a superfície de um sólido e o fluido adjacente, que aquece ou resfria o material sólido. A taxa de aquecimento ou resfriamento depende da velocidade do fluido em relação à superfície, da diferença de temperatura entre eles e das características de ambos. O fluxo de calor por unidade de área $\left(\mathrm{W} / \mathrm{m}^{2}\right)$ na convecção é definido pela Equação 14:

$$
\stackrel{\mathrm{g}}{\mathrm{q}}=h \cdot \Delta \mathrm{T}
$$

onde:

$h$ é o coeficiente de transferência de calor por convecção em $\mathrm{W} /\left(\mathrm{m}^{2} . \mathrm{K}\right)$;

$\Delta \mathrm{T}$ é a diferença de temperatura entre a superfície do sólido e o fluido em graus Celsius ou Kelvin.

Conforme Drysdale (1998), o coeficiente de transferência de calor por convecção pode variar com a condutividade térmica, viscosidade e densidade do fluido, a natureza do fluxo (convecção forçada ou natural) e da geometria da superfície. Segundo o autor, para problemas de convecção natural o valor de $h$ fica entre 5 e $25 \mathrm{~W} /\left(\mathrm{m}^{2} . \mathrm{K}\right)$.

De acordo com o Eurocode 1 Parte 1-2:2002 o coeficiente de convecção é 4 $\mathrm{W} /\left(\mathrm{m}^{2} . \mathrm{K}\right)$ para faces de elementos de separação não expostas ao fogo, $25 \mathrm{~W} /\left(\mathrm{m}^{2} . \mathrm{K}\right)$ para 
faces expostas à curva padrão de incêndio e $50 \mathrm{~W} /\left(\mathrm{m}^{2} . \mathrm{K}\right)$ para a curva de incêndio com hidrocarbonetos.

\subsubsection{Radiação}

A radiação, segundo Buchanan (2002), é a transferência de energia por meio de ondas eletromagnéticas e não precisa de um meio material para se propagar. Ela engloba tanto o espectro visível de luz com comprimentos de onda $\lambda$ entre 400 e $750 \mathrm{~nm}$ aproximadamente, quanto o espectro não visível, como pode ser observado na Figura 12.

Figura 12 - Espectro eletromagnético

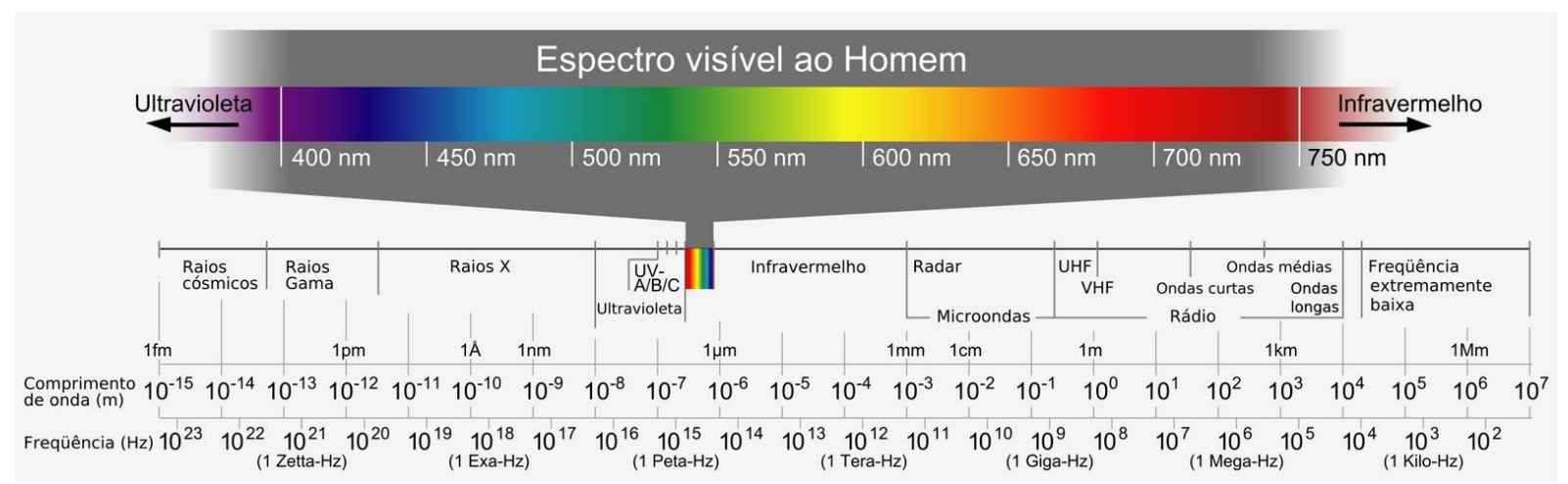

Fonte: Araújo (2013)

Segundo Drysdale (1998), a convecção pode ser predominante em baixas temperaturas, conforme o valor da emissividade e do coeficiente de transferência de calor por convecção. Mas acima de $400^{\circ} \mathrm{C}$ a radiação se torna o principal mecanismo de propagação de calor. Na temperatura aproximada de $550^{\circ} \mathrm{C}$ um objeto emite radiação suficiente para se tornar visível e conforme a temperatura aumenta a coloração muda, como pode ser observado na Tabela 5 .

Tabela 5 - Cores visíveis de objetos aquecidos

\begin{tabular}{cc}
\hline $\begin{array}{c}\text { Temperatura } \\
\left({ }^{\circ} \mathrm{C}\right)\end{array}$ & Aparência \\
\hline 550 & Primeiro brilho vermelho visível \\
700 & Vermelho escuro \\
900 & Vermelho cereja \\
1100 & Laranja \\
1400 & Branco \\
\hline
\end{tabular}

Fonte: Drysdale (1998) 
Conforme Buchanan (2002), o fluxo de calor resultante na radiação por unidade de área $\left(\mathrm{W} / \mathrm{m}^{2}\right)$ de uma superfície emissora para uma superfície receptora é dado pela Equação 15:

$\stackrel{\mathrm{g}}{\mathrm{q}^{\prime \prime}}=\varphi \cdot \in \cdot \sigma_{\mathrm{s}} \cdot\left(\mathrm{T}_{\mathrm{e}}^{4}-\mathrm{T}_{\mathrm{r}}^{4}\right)$

onde:

$\varphi$ é o fator de configuração;

$\in$ é a emissividade resultante das duas superfícies;

$\sigma_{\mathrm{s}}$ é a constante de Stefan-Boltzmann $\left(5,67 \times 10^{-8} \mathrm{~W} / \mathrm{m}^{2} \mathrm{~K}^{4}\right)$;

$\mathrm{T}_{\mathrm{e}}$ é a temperatura absoluta da superfície emissora em Kelvin;

$\mathrm{T}_{\mathrm{r}}$ é a temperatura absoluta da superfície receptora em Kelvin.

A emissividade indica a eficiência que uma superfície emite radiação, com valores variando entre zero e um. De acordo com Buchanan (2002), na situação de incêndio a maioria das superfícies aquecidas, chamas e partículas de fumaça, possuem emissividade entre 0,7 e 1,0. A emissividade resultante de duas superfícies pode ser calculada através da Equação 16:

$\in=\frac{1}{1 / \epsilon_{\mathrm{e}}+1 / \epsilon_{\mathrm{r}}-1}$

onde:

$\epsilon_{\mathrm{e}}$ é a emissividade da superfície emissora;

$\epsilon_{\mathrm{r}}$ é a emissividade da superfície receptora.

Estão indicadas na Tabela 6 as emissividades com as correspondentes temperaturas de alguns materiais: 
Tabela 6 - Emissividade de alguns materiais

\begin{tabular}{cccc}
\hline Superfície & $\begin{array}{c}\text { Temperatura } \\
\left({ }^{\circ} \mathrm{C}\right)\end{array}$ & Emissividade & Fonte \\
\hline Aço polido & 100 & 0,066 & Drysdale (1998) \\
Tijolo refratário & 1000 & 0,750 & Drysdale (1998) \\
Telhas de concreto & 1000 & 0,630 & Drysdale (1998) \\
Concreto & - & 0,700 & Eurocode 2 Parte 1-2:2004 \\
Concreto aparente & Ambiente & $0,850-0,950$ & ANBT NBR 15220-2:2005 \\
Tijolo aparente & Ambiente & $0,850-0,950$ & ANBT NBR 15220-2:2005 \\
Bloco cerâmico (argila queimada) & - & 0,900 & Nguyen et al. $(2009)$ \\
Bloco cerâmico & - & 0,950 & Rosemann (2011) \\
Basalto & 20 & 0,720 & Cole-Parmer (2017) \\
Tijolo refratário & 1371 & 0,750 & Cole-Parmer (2017) \\
Tijolo vermelho & 21 & 0,930 & Cole-Parmer (2017) \\
Concreto áspero & 0 a 93 & 0,940 & Cole-Parmer (2017) \\
\hline
\end{tabular}

O fator de configuração $\varphi$ é uma medida da radiação incidente sobre a superfície receptora devido à superfície emissora, segundo Buchanan (2002). Para os casos gerais, conforme ilustra a Figura 13, o fator de configuração para a radiação incidente no ponto 2, a uma distância $r$ do ponto 1, é definido pela Equação 17:

$\varphi=\int_{\mathrm{A}_{1}} \frac{\cos \theta_{1} \cdot \cos \theta_{2}}{\pi \cdot r^{2}} \mathrm{dA}_{1}$ 
Figura 13 - Radiação incidente sobre uma superfície

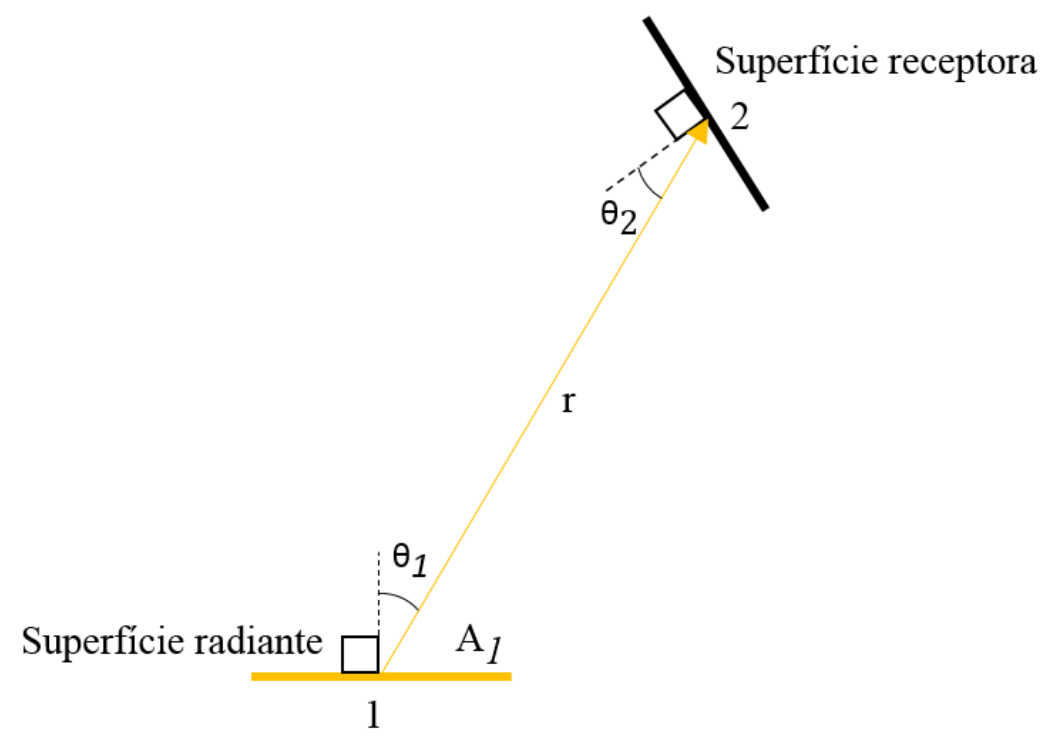

Fonte: Adaptado de Drysdale (1998)

Para o caso particular de duas superfícies paralelas, o fator de configuração $\varphi$ para a radiação incidente em um ponto a uma distância $r$ do centro de uma superfície emissora retangular com largura $\mathrm{W}$ e altura $\mathrm{H}$, é dado pela Equação 18:

$\varphi=\frac{1}{90}\left[\frac{\mathrm{x}}{\sqrt{1+\mathrm{x}^{2}}} \tan ^{-1}\left(\frac{\mathrm{y}}{\sqrt{1+\mathrm{x}^{2}}}\right)+\frac{\mathrm{y}}{\sqrt{1+\mathrm{y}^{2}}} \tan ^{-1}\left(\frac{\mathrm{x}}{\sqrt{1+\mathrm{y}^{2}}}\right)\right]$

onde:

$\mathrm{x}=\mathrm{H} / 2 r$ e $\mathrm{y}=\mathrm{W} / 2 r$.

\subsection{PROPRIEDADES TÉRMICAS DOS PRINCIPAIS COMPONENTES DA ALVENARIA ESTRUTURAL}

Vários aspectos influenciam o comportamento da alvenaria em situação de incêndio. Conforme Adreini et al. (2014), a forma, geometria e textura dos blocos, espessura das juntas de argamassa, teor de umidade dos componentes, as dimensões e restrições dos painéis, a forma de exposição ao fogo, etc. interferem no desempenho da alvenaria. Assim, uma tentativa de se prever o seu comportamento envolve o conhecimento do desempenho dos materiais que a compõem mediante a ação do fogo. 


\subsubsection{Unidades cerâmicas}

O material cerâmico é conhecido por apresentar considerável resistência ao fogo. Em Rosemann (2011) foi constatado que paredes de blocos cerâmicos sem revestimento e preenchimento possuem classe de resistência ao fogo de 90 minutos sem a aplicação de carregamento, e que esse valor de resistência é superior ao obtido em alvenarias com blocos de concreto.

As unidades cerâmicas apresentam baixa condutividade térmica comparada ao aço, por exemplo. Na Tabela 7 são apresentados valores de condutividade térmica e calor específico para unidades de diferentes massas específicas em temperatura ambiente, encontrados em algumas referências bibliográficas.

Tabela 7 - Propriedades térmicas das unidades cerâmicas em temperatura ambiente

\begin{tabular}{ccccc}
\hline Material & $\begin{array}{c}\text { Massa } \\
\text { específica } \\
\mathrm{kg} / \mathrm{m}^{3}\end{array}$ & $\begin{array}{c}\text { Condutividade } \\
\text { térmica } \\
\mathrm{W} /(\mathrm{m} . \mathrm{K})\end{array}$ & $\begin{array}{c}\text { Calor } \\
\text { específico } \\
\mathrm{J} /(\mathrm{kg} . \mathrm{K})\end{array}$ & Fonte \\
\hline $\begin{array}{c}\text { Bloco } \\
\text { cerâmico }\end{array}$ & 1800 & 1,00 & - & Chichierchio (1990) \\
$\begin{array}{c}\text { Tijolo } \\
\text { cerâmico }\end{array}$ & 2000 & 1,20 & - & ASCE (1992) \\
$\begin{array}{c}\text { Tijolo comum } \\
\text { Tijolo }\end{array}$ & 1600 & 0,69 & 840 & Drysdale (1998) \\
Tijolo & $1300-1600$ & 0,90 & 920 & ANBT NBR 15220-2:2005 \\
Tijolo & $1600-1800$ & 1,00 & 920 & ANBT NBR 15220-2:2005 \\
Tijolo & $1800-2000$ & 1,05 & 920 & ANBT NBR 15220-2:2005 \\
$\begin{array}{c}\text { Bloco (argila } \\
\text { refratária) }\end{array}$ & 1836 & 1,27 & 870 & Nguyen et al. (2009) \\
$\begin{array}{c}\text { Bloco } \\
\text { cerâmico }\end{array}$ & 1750 & 1,80 & 700 & Rosemann (2011) \\
\hline
\end{tabular}

O Eurocode 6 Parte 1-2:2005 apresenta a variação da condutividade térmica e calor específico de acordo com a elevação de temperatura, para unidades cerâmicas com massa específica de 900 a $1200 \mathrm{~kg} / \mathrm{m}^{3}$, conforme disposto na Figura 14. A massa específica é considerada constante conforme a elevação de temperatura. 
Figura 14 - Condutividade térmica e calor específico de unidades cerâmicas

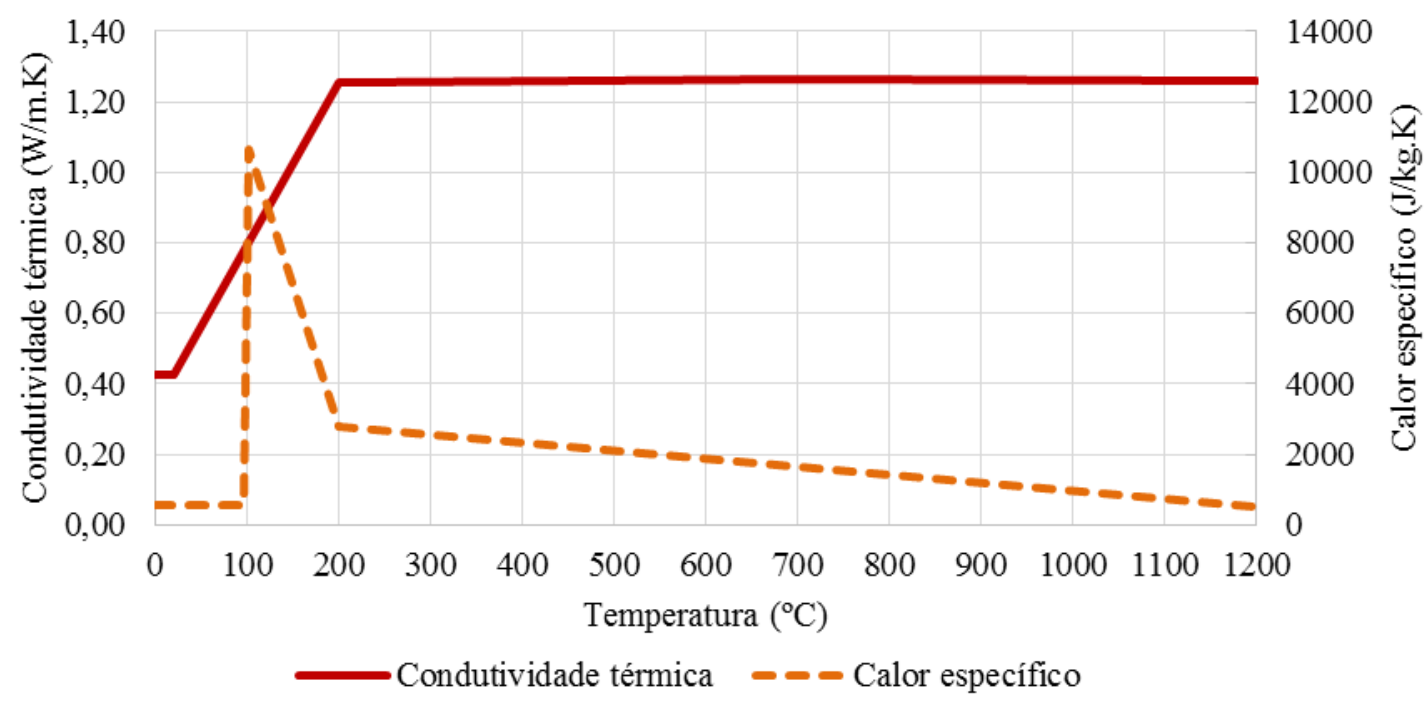

Fonte: Adaptado de Eurocode 6 Parte 1-2 (2005)

O coeficiente de expansão térmica das unidades depende da sua forma de produção. Unidades produzidas com argila refratária possuem menor coeficiente de expansão térmica que as produzidas com xisto. Conforme Drysdale, Hamid e Baker (1994) o coeficiente de expansão térmica fica entre $3,1 \times 10^{-6 \circ} \mathrm{C}^{-1}$ e $12,4 \times 10^{-6 \circ} \mathrm{C}^{-1}$. A ABNT NBR 15812-1:2010 sugere o valor de $6,0 \times 10^{-60} \mathrm{C}^{-1}$ para o coeficiente de dilatação térmica linear da alvenaria composta por blocos cerâmicos, na ausência de dados experimentais.

Russo e Sciarretta (2014) utilizaram em suas modelagens o coeficiente de expansão de 4,0 x $10^{-60} \mathrm{C}^{-1}$ para tijolo cerâmico maciço com massa específica de $1600 \mathrm{~kg} / \mathrm{m}^{3}$. Conforme Rosemann (2011) o coeficiente de expansão de blocos cerâmicos é $5,5 \times 10^{-6 \circ} \mathrm{C}^{-1}$. Nguyen et al. (2009) aplicaram o valor constante de $5,25 \times 10^{-6 \circ} \mathrm{C}^{-1}$ para blocos de argila refratária com massa específica de $1836 \mathrm{~kg} / \mathrm{m}^{3}$ e apresentaram o gráfico da Figura 15 de variação do coeficiente de expansão conforme a elevação de temperatura. 
Figura 15 - Variação do coeficiente de expansão térmica de bloco cerâmico

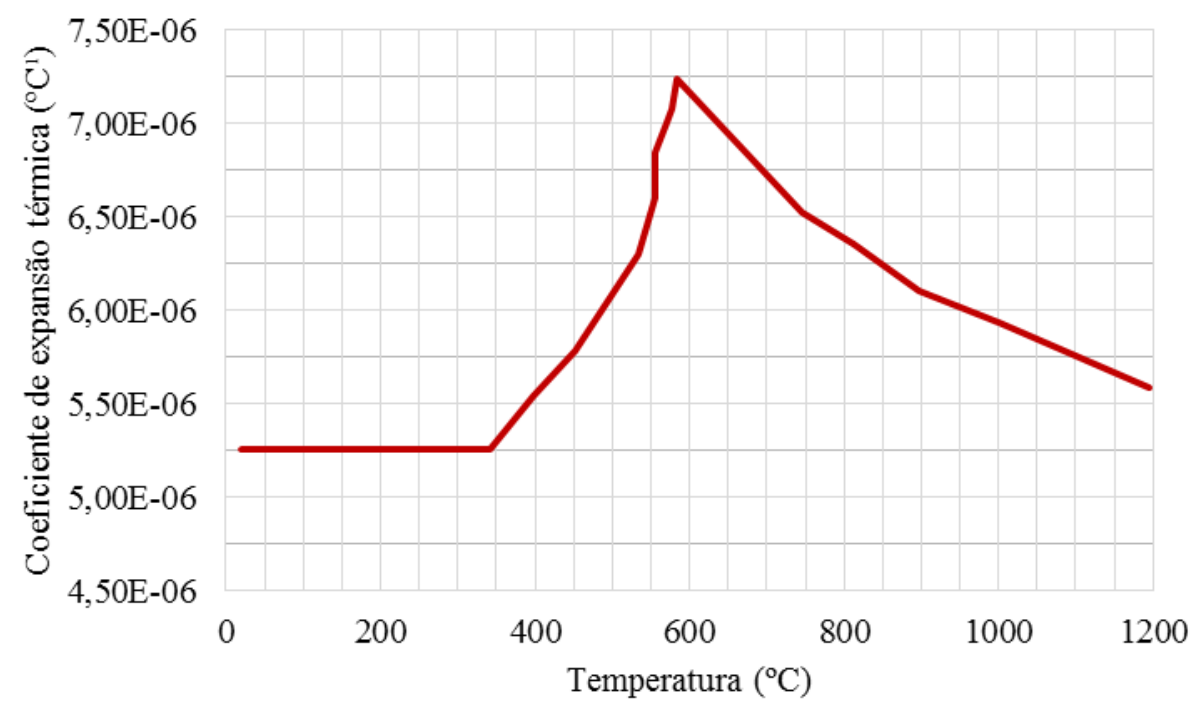

Fonte: Nguyen et al. (2009)

\subsubsection{Unidades de concreto}

O concreto é um material não combustível e apresenta baixa condutividade térmica. Estruturas construídas com este material geralmente possuem bom desempenho quando submetidas a elevadas temperaturas. Na Tabela 8 estão presentes valores de condutividade térmica e calor específico para o concreto e blocos de concreto com diferentes massas específicas em temperatura ambiente. 
Tabela 8 - Propriedades térmicas do concreto e de blocos de concreto

\begin{tabular}{|c|c|c|c|c|}
\hline Material & $\begin{array}{c}\text { Massa } \\
\text { específica } \\
\mathrm{kg} / \mathrm{m}^{3}\end{array}$ & $\begin{array}{c}\text { Condutividade } \\
\text { térmica } \\
\text { W/(m.K) }\end{array}$ & $\begin{array}{c}\text { Calor } \\
\text { específico } \\
\mathrm{J} /(\mathrm{kg} . \mathrm{K})\end{array}$ & Fonte \\
\hline Blocos de concreto & 1800 & 1,10 & - & Chichierchio (1990) \\
\hline Blocos de concreto & 2000 & 1,51 & - & Chichierchio (1990) \\
\hline Blocos de concreto & 2150 & 1,69 & - & Chichierchio (1990) \\
\hline Blocos de concreto & 2200 & 1,74 & - & Chichierchio (1990) \\
\hline Blocos de concreto & 2300 & 1,81 & - & Chichierchio (1990) \\
\hline Concreto leve & 1600 & 0,80 & - & ASCE (1992) \\
\hline $\begin{array}{l}\text { Concreto de peso normal } \\
\text { (agregado amorfo) }\end{array}$ & 2200 & 1,30 & - & ASCE (1992) \\
\hline $\begin{array}{l}\text { Concreto de peso normal } \\
\text { (agregado cristalino) }\end{array}$ & 2200 & 1,70 & - & ASCE (1992) \\
\hline Concreto & $1900-2300$ & $0,80-1,40$ & 880 & Drysdale (1998) \\
\hline $\begin{array}{c}\text { Concreto com argila } \\
\text { expandida }\end{array}$ & $1000-1200$ & 0,46 & 1000 & ANBT NBR 15220-2:2005 \\
\hline $\begin{array}{c}\text { Concreto com argila } \\
\text { expandida }\end{array}$ & $1200-1400$ & 0,70 & 1000 & ANBT NBR 15220-2:2005 \\
\hline $\begin{array}{c}\text { Concreto com argila } \\
\text { expandida }\end{array}$ & $1400-1600$ & 0,85 & 1000 & ANBT NBR 15220-2:2005 \\
\hline $\begin{array}{c}\text { Concreto com argila } \\
\text { expandida }\end{array}$ & $1600-1800$ & 1,05 & 1000 & ANBT NBR 15220-2:2005 \\
\hline Concreto cavernoso & $1700-2100$ & 1,40 & 1000 & ANBT NBR 15220-2:2005 \\
\hline Concreto normal & $2200-2400$ & 1,75 & 1000 & ANBT NBR 15220-2:2005 \\
\hline Blocos de concreto & 2000 & 2,00 & 900 & Nahhas et al. (2007) \\
\hline Blocos de concreto leve & 800 & 0,21 & 1170 & Andreini e Sassu (2011) \\
\hline Concreto & 2400 & 1,67 & 1000 & Alves (2014) \\
\hline Blocos de concreto & 2200 & 1,50 & 1000 & Bloco Brasil (2016) \\
\hline
\end{tabular}

O Eurocode 2 Parte 1-2:2004 apresenta a variação da condutividade térmica de acordo com a elevação de temperatura para o concreto. Na Figura 16 estão presentes os limites superior e inferior de condutividade, assim como a média desses valores. 
Figura 16 - Limites superior e inferior de condutividade térmica do concreto

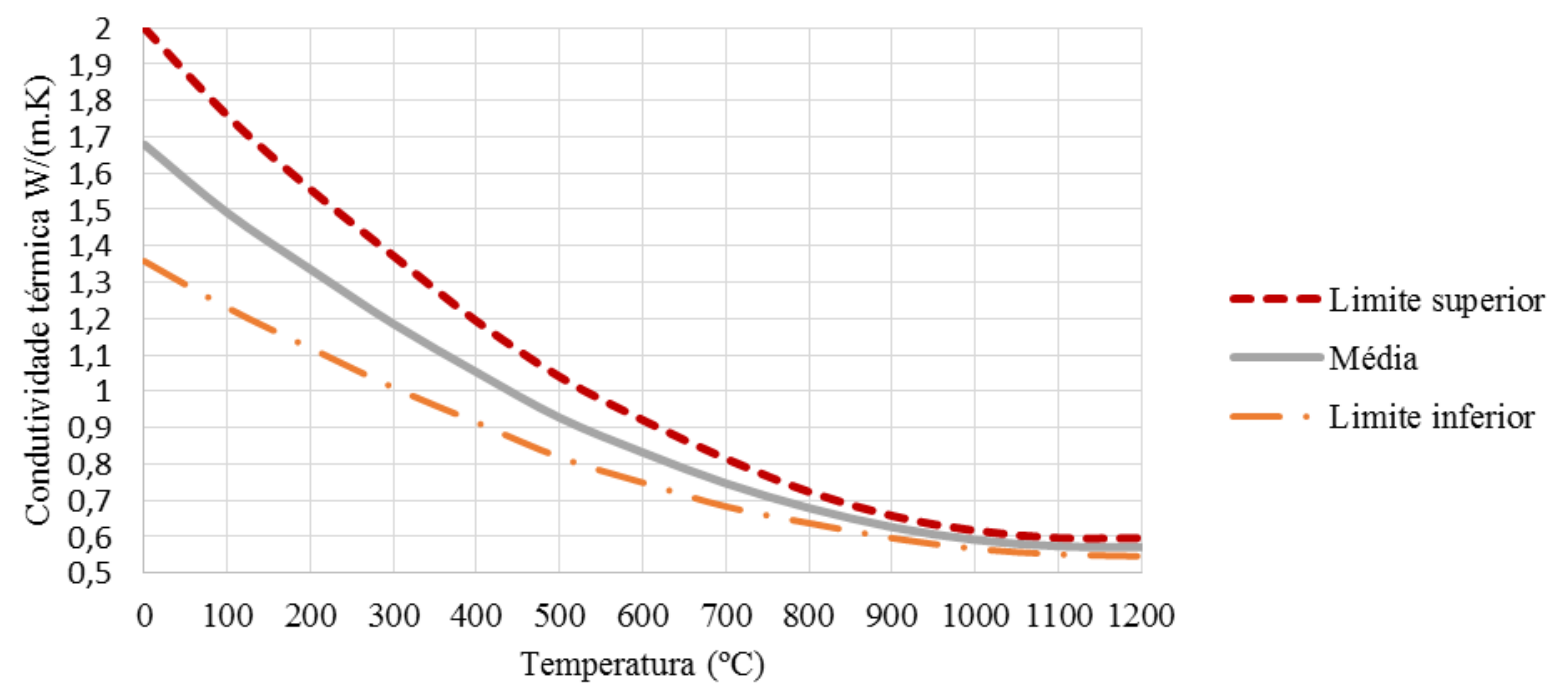

Fonte: Adaptado de Eurocode 2 Parte 1-2:2004

A mesma referência também apresenta a variação de calor específico do concreto para três teores diferentes de umidade (u), conforme ilustra a Figura 17.

Figura 17 - Variação do calor específico do concreto conforme o teor de umidade

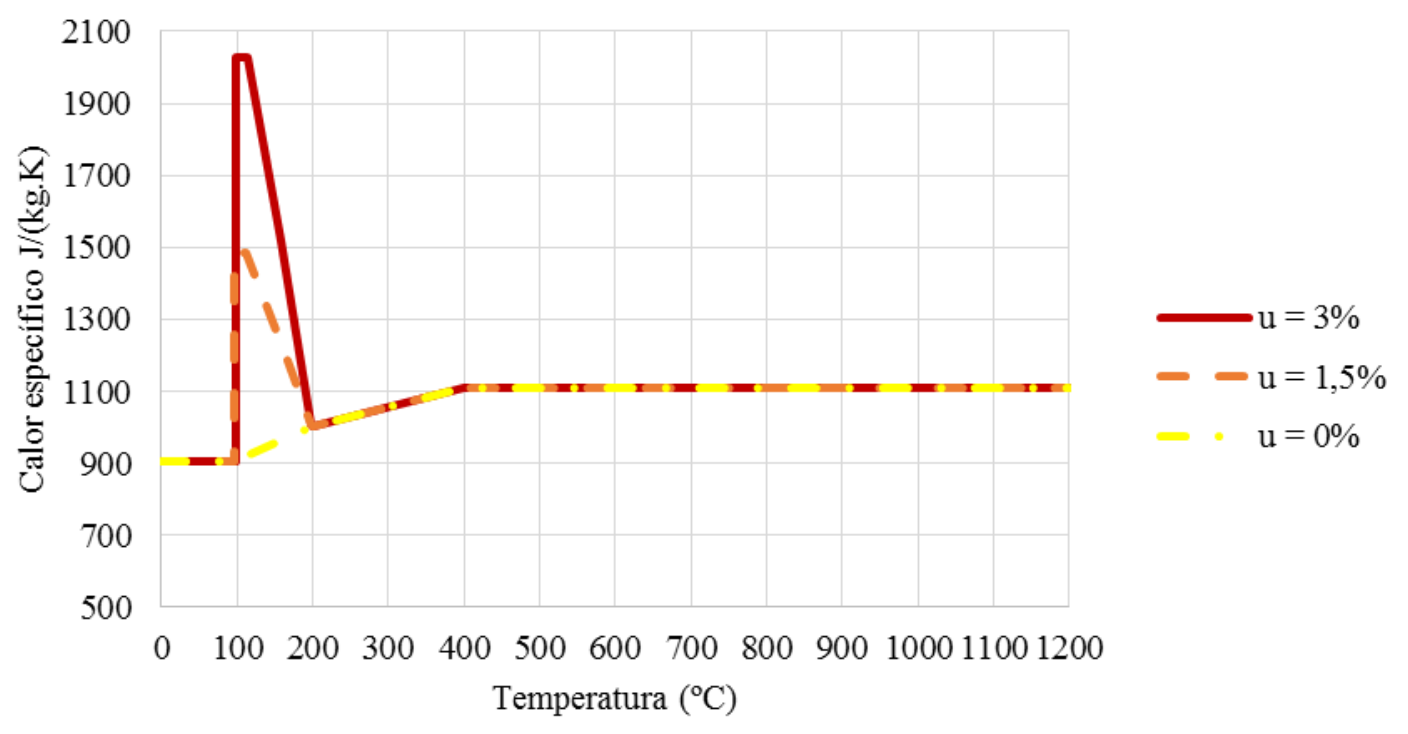

Fonte: Adaptado de Eurocode 2 Parte 1-2:2004

De acordo com Buchanan (2002) quando aquecida, a pasta de cimento sofre reação endotérmica reduzindo a elevação de temperatura da estrutura exposta ao fogo. Blocos que 
são fabricados com concreto leve têm melhor desempenho em situação de incêndio, sendo que isso se deve às propriedades térmicas dos agregados.

Conforme a Fédération Internationale du Béton - FIB 46 (2008) concretos calcários possuem condutividade térmica mais baixa que concretos silicosos, portanto, agem de forma diferente em situação de incêndio. Agregados leves dispõem de condutividade térmica ainda mais baixa.

Estruturas submetidas a elevadas temperaturas sofrem efeitos da mudança de propriedades do material, conforme Wang (2002). O concreto perde resistência e se torna mais flexível. Além disso, esforços internos podem ser gerados caso a expansão térmica da estrutura esteja restringida.

Segundo Cánovas (1988), variações significativas na temperatura causam importantes modificações no concreto. A partir de $100^{\circ} \mathrm{C}$ o aquecimento é retardado devido ao início da evaporação da água capilar. A total perda de água capilar se dá entre 200 e $300^{\circ} \mathrm{C}$. Entre 300 e $400^{\circ} \mathrm{C}$ surgem as primeiras fissuras do concreto e ocorre uma leve redução de sua resistência causada pela perda de água de gel do cimento. Parte do hidróxido de cálcio se transforma em óxido de cálcio aos $400^{\circ} \mathrm{C}$. Tensões internas são geradas devido à diferença de coeficiente de dilatação dos agregados até os $600^{\circ} \mathrm{C}$, começando a desagregar o concreto.

Entretanto, de acordo com FIB 38 (2007), a distribuição de temperaturas não uniformes no início do aquecimento do concreto gera a migração do vapor de água nos poros capilares da pasta de cimento para zonas de temperaturas mais baixas, aumentando a porosidade e causando a sua degradação progressiva. Esta migração inicial colabora para evitar a excessiva elevação de pressão. O impedimento da movimentação de umidade pode causar o lascamento do concreto.

Ainda segundo FIB 38 (2007), o aumento de temperatura provoca a expansão dos agregados enquanto a matriz de cimento sofre retração acima de $150^{\circ} \mathrm{C}$, após inicialmente ter se expandido, instaurando a microfissuração do concreto. Em temperaturas acima do ponto crítico da água de $374,15^{\circ} \mathrm{C}$, quando não é possível a água existir no estado líquido, ocorrem reações primárias como a decomposição do carbonato de cálcio e transformações nos componentes de sílica.

A expansão do concreto depende da massa específica e do tipo de agregado utilizado em sua confecção. Drysdale, Hamid e Baker (1994) sugerem o valor do coeficiente de dilatação térmica linear de $9,0 \times 10^{-6}{ }^{\circ} \mathrm{C}^{-1}$ para unidades de peso normal e 7,2 $\times 10^{-6}{ }^{\circ} \mathrm{C}^{-1}$ para unidades leves. Na ABNT NBR 15961-1:2011 consta apenas o primeiro valor, sugerido para o caso de ausência de dados experimentais. Conforme Rosemann (2011) o coeficiente de expansão do 
concreto é cerca de $14,5 \times 10^{-6}{ }^{\circ} \mathrm{C}^{-1}$. Schneider (1988) apresenta a deformação térmica para concretos com diferentes tipos de agregados conforme ilustra a Figura 18.

Figura 18 - Deformação térmica de concretos com diferentes tipos de agregados

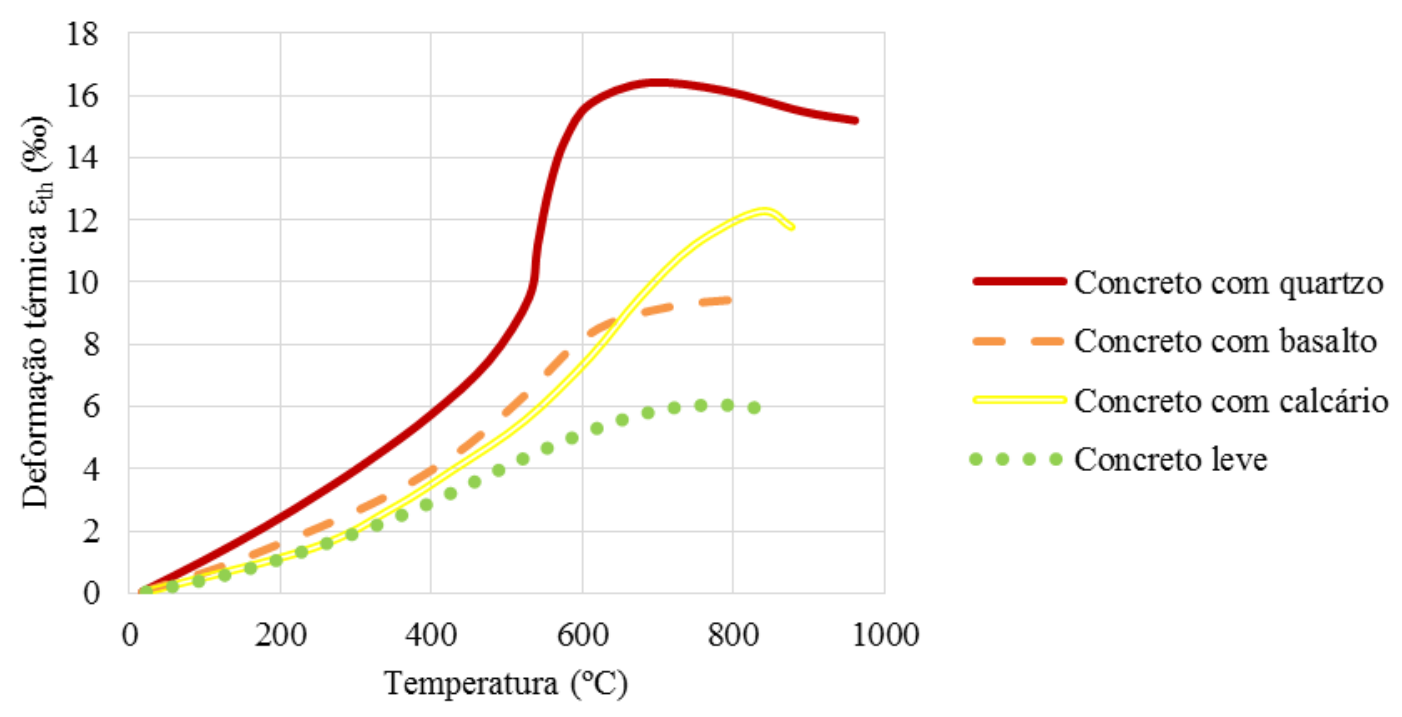

Fonte: Schneider (1988)

Observa-se que acima de $800^{\circ} \mathrm{C}$ não ocorre expansão do concreto com basalto. Concretos com boa distribuição granulométrica e elevada proporção de agregados em relação ao cimento suportam mais a ação do fogo que concretos com má distribuição granulométrica e com baixo teor de agregados, de acordo com Cánovas (1988).

A coloração do concreto e sua resistência se modificam de acordo com o aumento de temperatura. Segundo Cánovas (1988) a mudança de coloração só pode ser observada quando se têm agregados silicosos no concreto. Como pode ser observado na Figura 19 , até $300^{\circ} \mathrm{C}$ não há perda significativa na resistência à compressão do concreto. A $600^{\circ} \mathrm{C}$ o concreto possui cerca de $50 \%$ de sua resistência à compressão inicial e quando é atingida a temperatura de $1000^{\circ} \mathrm{C}$ sua resistência é totalmente eliminada. 
Figura 19 - Influência da temperatura sobre a resistência à compressão do concreto

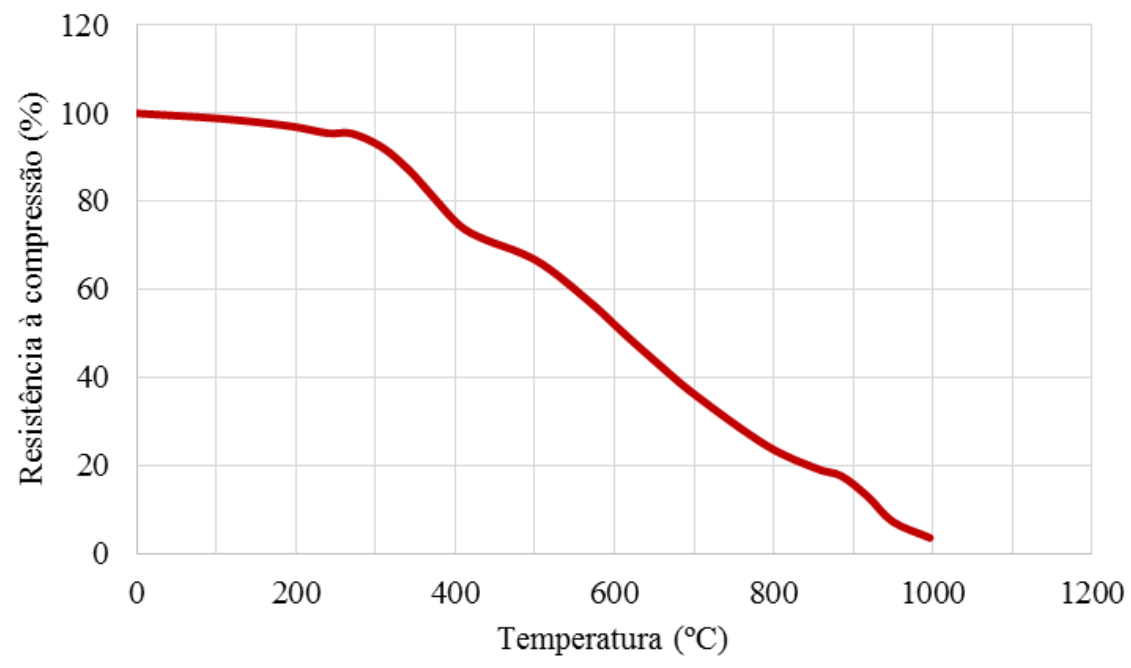

Fonte: Adaptado de Cánovas (1988)

\subsubsection{Argamassa}

Na Tabela 9 estão dispostos os valores de condutividade térmica e calor específico para argamassas com diferentes massas específicas em temperatura ambiente. $\mathrm{O}$ traço apresentado em Stancato (2000) é em massa e significa cimento : areia : água.

Tabela 9 - Propriedades térmicas da argamassa em temperatura ambiente

\begin{tabular}{|c|c|c|c|c|}
\hline Material & $\begin{array}{c}\text { Massa } \\
\text { específica } \\
\mathrm{kg} / \mathrm{m}^{3}\end{array}$ & $\begin{array}{c}\text { Condutividade } \\
\text { térmica } \\
\mathrm{W} /(\mathrm{m} . \mathrm{K})\end{array}$ & $\begin{array}{c}\text { Calor } \\
\text { específico } \\
\mathrm{J} /(\mathrm{kg} . \mathrm{K})\end{array}$ & Fonte \\
\hline $\begin{array}{c}\text { Argamassa convencional } \\
\qquad 1: 3: 0,8\end{array}$ & 1828 & 0,946 & - & Stancato (2000) \\
\hline $\begin{array}{c}\text { Argamassa convencional } \\
1: 3: 0,62\end{array}$ & 1928 & 1,095 & - & Stancato (2000) \\
\hline $\begin{array}{c}\text { Argamassa convencional } \\
1: 3: 0,63\end{array}$ & 2001 & 1,175 & - & Stancato (2000) \\
\hline Argamassa celular & $600-1000$ & 0,400 & 1000 & $\begin{array}{c}\text { ANBT NBR 15220- } \\
\text { 2:2005 }\end{array}$ \\
\hline $\begin{array}{l}\text { Argamassa de gesso (ou } \\
\text { cal e gesso) }\end{array}$ & 1200 & 0,700 & 840 & $\begin{array}{c}\text { ANBT NBR 15220- } \\
2: 2005\end{array}$ \\
\hline Argamassa comum & $1800-2100$ & 1,150 & 1000 & $\begin{array}{c}\text { ANBT NBR 15220- } \\
\text { 2:2005 }\end{array}$ \\
\hline Argamassa & 1500 & 1,500 & 1170 & Nguyen et al. (2009) \\
\hline Argamassa & 2100 & 1,500 & 800 & Rosemann (2011) \\
\hline
\end{tabular}


Em Stancato (2000) é apresentada a variação de condutividade térmica com o passar do tempo e observa-se que inicialmente as argamassas possuem valores superiores de condutividade que vão reduzindo com o tempo. O maior valor encontrado inicialmente foi de $2,023 \mathrm{~W} /(\mathrm{m} . \mathrm{K})$ para a argamassa com areia fina siltosa com o traço de 1:3:0,62. Na Tabela 9 foram apresentados os valores médios.

Ayala (2010) empregou em sua pesquisa argamassa com traço de 1:1:5 em volume, sendo cimento : cal hidratada : areia, fator água/cimento de 1,7 e massa específica de 1900 $\mathrm{kg} / \mathrm{m}^{3}$. Os valores de condutividade térmica adotados pelo autor foi de $2,9 \mathrm{~W} /(\mathrm{m} . \mathrm{K})$ para a temperatura de $200^{\circ} \mathrm{C}$ e $1,4 \mathrm{~W} /(\mathrm{m} . \mathrm{K})$ para as temperaturas de 400 a $800{ }^{\circ} \mathrm{C}$.

Russo e Sciarretta (2014) utilizaram em suas simulações o valor de $6,6 \times 10^{-60} \mathrm{C}^{-1}$ para o coeficiente de expansão térmica da argamassa com resistência à compressão de $10 \mathrm{MPa}$. Já Nguyen et al. (2009) aplicaram o valor de $1 \times 10^{-50} \mathrm{C}^{-1}$ para argamassa com massa específica de $1500 \mathrm{~kg} / \mathrm{m}^{3}$.

Cülfik e Özturan (2012) analisaram a resistência residual à compressão da argamassa de massa específica de $2160 \mathrm{~kg} / \mathrm{m}^{3}$ submetida a temperaturas elevadas. Foram moldados corpos de prova cilíndricos que foram aquecidos com taxas de 2 e $8^{\circ} \mathrm{C} / \mathrm{min}$., até temperaturas de 300,600 e $900^{\circ} \mathrm{C}$, mantidas durante 1 e 10 horas. Em seguida os cilindros foram resfriados com taxa de $0,4^{\circ} \mathrm{C} / \mathrm{min}$. A Figura 20 mostra a redução na resistência à compressão da argamassa com a elevação de temperatura para os diferentes casos.

Figura 20 - Redução da resistência à compressão da argamassa com a elevação de temperatura

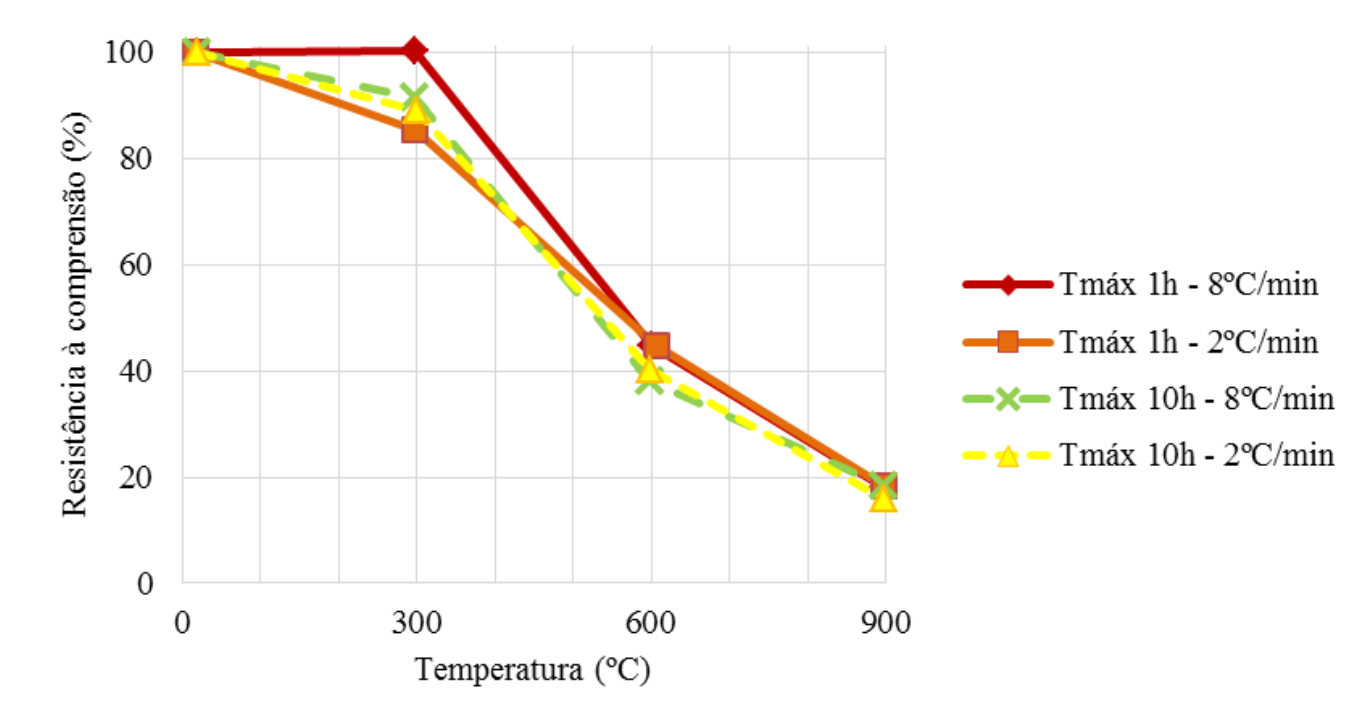

Fonte: Cülfik e Özturan (2012) 
Observa-se comportamento semelhante à perda de resistência à compressão do concreto apresentada na Figura 19. Os autores também analisaram a redução do módulo de elasticidade, conforme ilustra a Figura 21 até a temperatura de $600^{\circ} \mathrm{C}$.

Figura 21 - Redução do módulo de elasticidade da argamassa com a elevação de temperatura

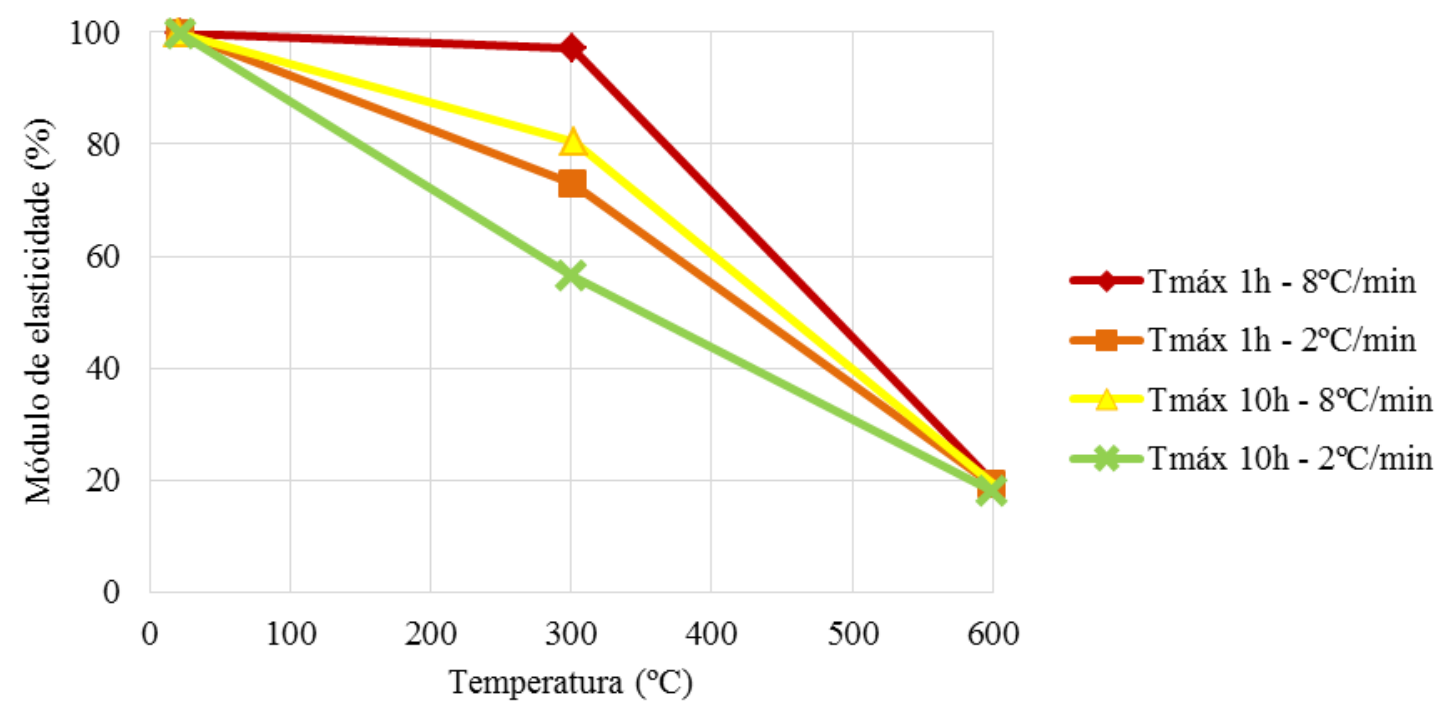

Fonte: Cülfik e Özturan (2012)

\subsection{SIMULAÇÃO NUMÉRICA}

As análises mecânica e térmica geralmente não estão integradas, e sim interligadas, conforme FIB 38 (2007). Primeiramente é efetuada a análise térmica durante toda a simulação do incêndio. Então, o cálculo térmico é introduzido na análise mecânica. Assim, são apresentadas as duas análises separadamente.

\subsubsection{Análise mecânica}

A alvenaria estrutural é um sistema construtivo que apresenta comportamentos distintos em cada direção. Isto ocorre devido à existência das aberturas e das juntas de argamassa que atuam como planos de fraqueza.

Conforme Lourenço (1996) a abordagem numérica da alvenaria pode ser feita por meio da micromodelagem, onde as unidades e a argamassa são discretizadas separadamente, 
ou através da macromodelagem tratando a alvenaria como um compósito. Na Figura 22 são apresentadas as técnicas de modelagem da alvenaria.

Figura 22 - Técnicas de modelagem da alvenaria: (a)Esquema da alvenaria;

(b)Micromodelagem; (c)Micromodelagem simplificada; (d)Macromodelagem

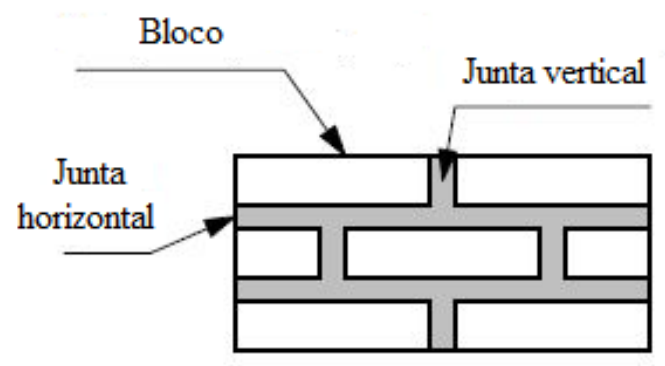

(a)

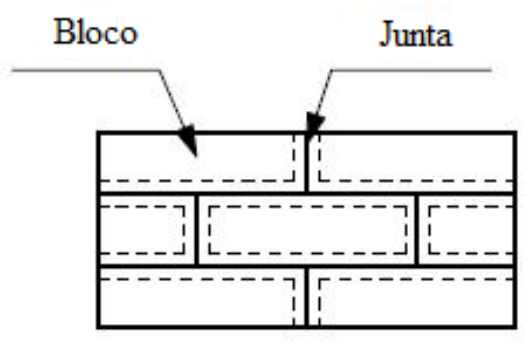

(c)

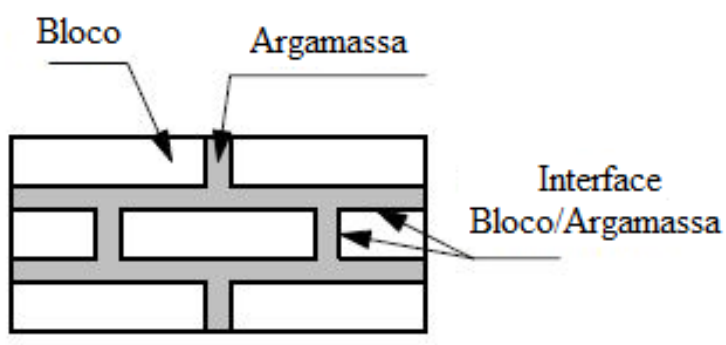

(b)

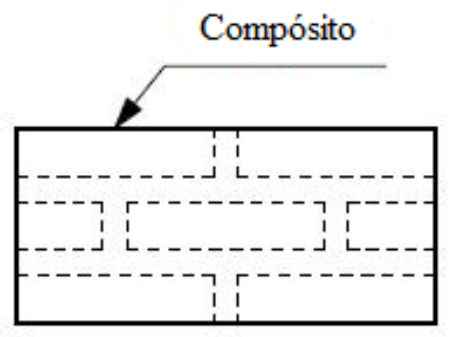

(d)

Fonte: Lourenço (1996)

Na micromodelagem são detalhadas as unidades e as juntas de argamassa unidas por elementos de interface. Já na micromodelagem simplificada, as unidades possuem dimensões acrescidas da metade da espessura das juntas de argamassa para manter as dimensões da parede e as juntas de argamassa são representadas por elementos de interface. A macromodelagem é feita considerando-se a alvenaria com propriedades homogêneas, como um meio contínuo.

De acordo com Lourenço (1996) a escolha do tipo de abordagem deve ser feita de acordo com o que se pretende analisar. A micromodelagem é destinada ao entendimento do comportamento local da alvenaria, como o estudo da distribuição de tensões em aberturas de portas e janelas. A macromodelagem é indicada quando se tem parede com dimensões suficientes para esta possuir distribuição de tensões praticamente uniforme.

A causa frequente da ruptura na alvenaria é a fissuração, a qual é gerada por excessivas deformações e esforços de tração. Compreender os mecanismos de ruptura é um passo importante para o entendimento do comportamento da alvenaria. 


\subsubsection{Mecanismos de ruptura}

Segundo Lourenço e Rots (1997) um modelo preciso para a simulação da alvenaria deve incluir seus mecanismos básicos de ruptura, que são:

a) Fissura nas juntas horizontais de argamassa quando a alvenaria é tracionada;

b) Escorregamento do bloco através das juntas horizontais ou verticais de argamassa;

c) Fissuração das unidades e argamassa perpendicular à direção de tração;

d) Fissuração diagonal das unidades devido à tensão normal suficiente para gerar atrito nas juntas;

e) Fissuração das unidades tracionadas devido à expansão horizontal da argamassa causada por tensão normal elevada de compressão.

Estes principais mecanismos estão ilustrados na Figura 23.

Figura 23 - Principais mecanismos de ruptura da alvenaria

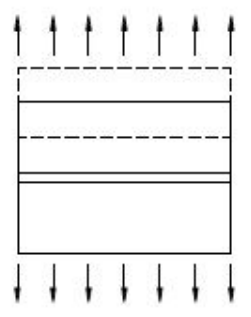

(a)

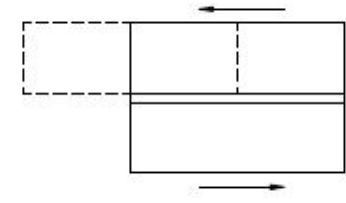

(b)

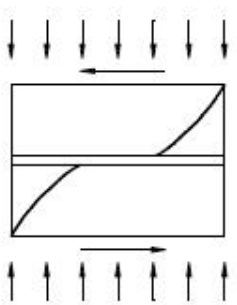

(d)

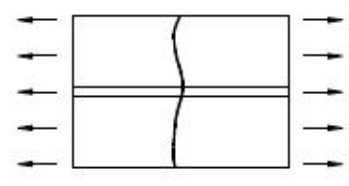

(c)
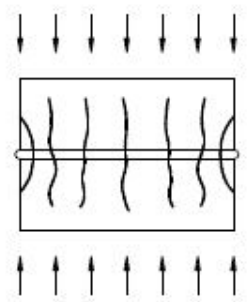

(e)

Fonte: Lourenço e Rots (1997) 
O mecanismo de ruptura dos elementos submetidos à tração e à compressão é o crescimento das fissuras, ou seja, são análogos, conforme Peleteiro (2002). A energia de fratura é acumulada por meio das deformações inelásticas e liberada na ocorrência da fratura interna.

O mecanismo de falha relacionado à tensão de tração é denominado modo I. Nele a fissura se propaga perpendicularmente à tensão aplicada. O modo II está associado à tensão de cisalhamento. A fissura se propaga paralelamente à tensão aplicada, é formada pelo escorregamento entre as faces. A ligação entre o bloco e a argamassa geralmente é a parte mais frágil da alvenaria. Os esquemas "a" e "b" da Figura 23 são associados aos modos I e II, respectivamente.

Os materiais frágeis, como o bloco de concreto, cerâmico e argamassa, apresentam o fenômeno de amolecimento, que é o gradual decréscimo da resistência mecânica devido ao incremento contínuo de deformação. Na Figura 24 são ilustrados os diagramas tensãodeslocamento de materiais frágeis submetidos à tração e compressão uniaxial. 
Figura 24 - Diagrama tensão-deslocamento de materiais frágeis: (a)Tração; (b)Compressão
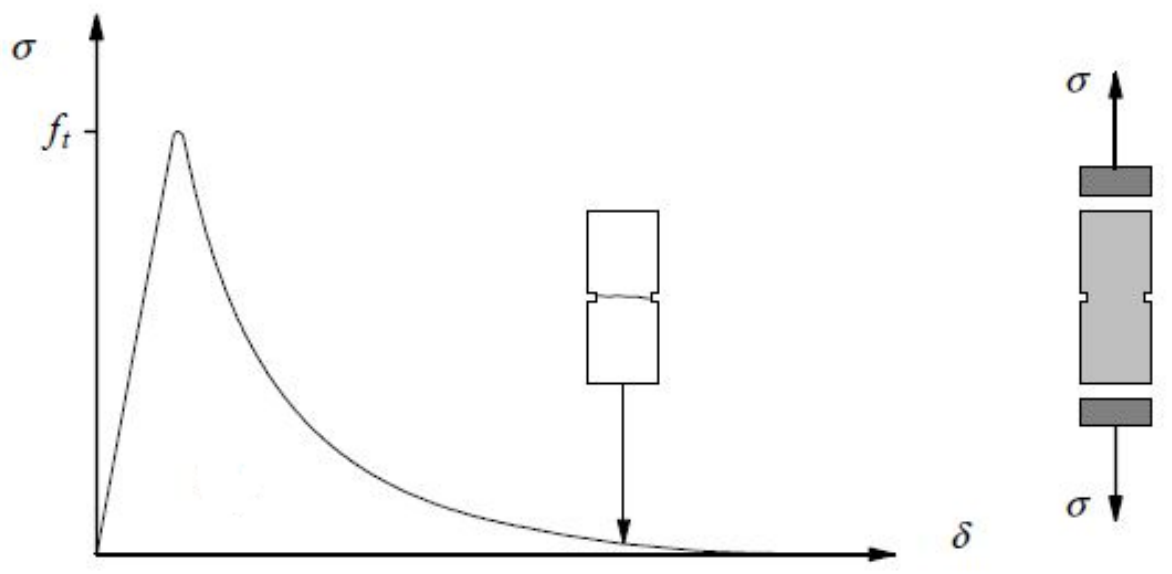

(a)
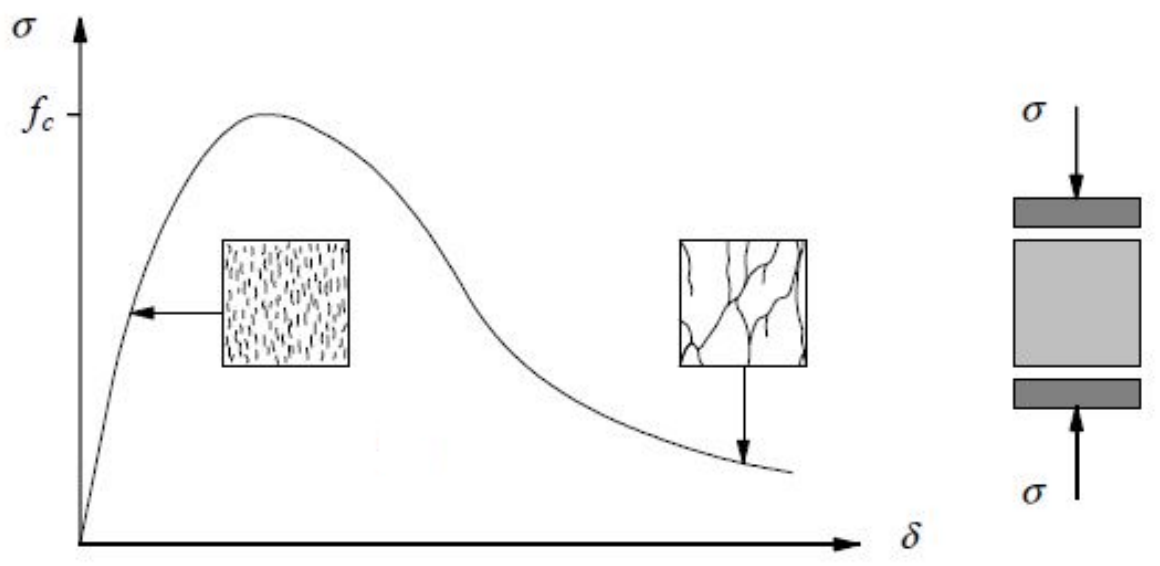

(b)

Fonte: Lourenço (1996)

A Figura 25 apresenta os diagramas tensão-deslocamento de materiais frágeis sujeitos ao cisalhamento ou modo II de fratura. 
Figura 25 - Diagrama tensão de cisalhamento-deslocamento de materiais frágeis
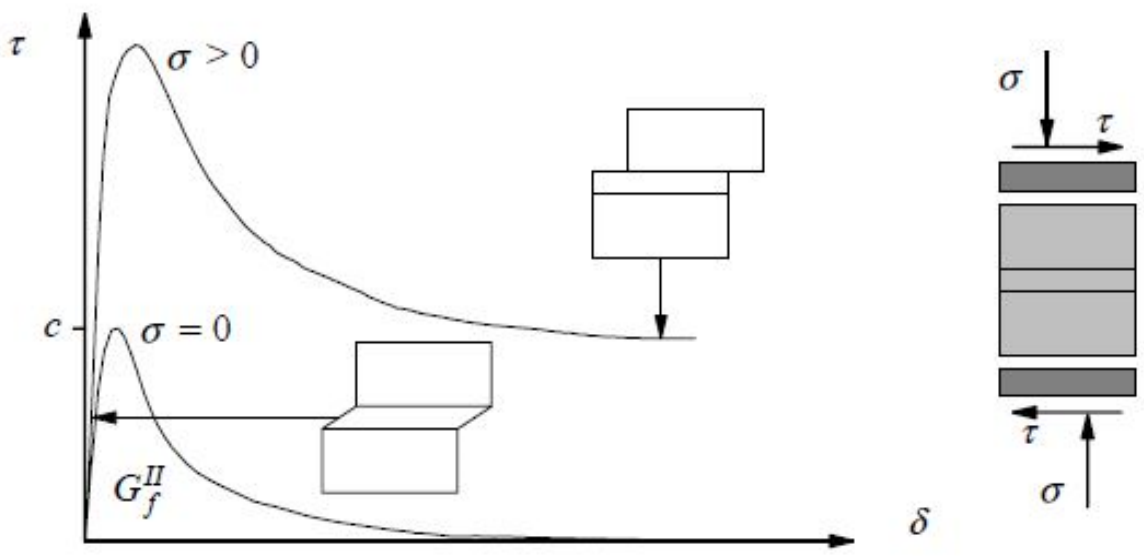

Fonte: Lourenço (1996)

Observa-se que o material que não está comprimido apresenta resistência ao cisalhamento significativamente inferior. A energia de fratura do modo II, $\mathrm{G}_{\mathrm{f}}^{\mathrm{II}}$, é definida pela integral do diagrama tensão de cisalhamento-deslocamento na ausência de tensão normal confinante.

\subsubsection{Modelo de plasticidade do Abaqus}

O software Abaqus possui modelos de plasticidade que permitem simular o comportamento do concreto. O modelo escolhido para esta pesquisa foi o Concrete damaged plasticity. Nele é possível simular o concreto submetido a carregamento cíclico, não cíclico e dinâmico. A evolução da superfície de falha é controlada pela deformação plástica associada à tração e à compressão, $\stackrel{\sim p l}{\mathcal{E}_{t}}$ e $\stackrel{\sim p l}{\mathcal{E}_{c}}$ respectivamente, vinculada aos mecanismos de falha.

Sob tração uniaxial, o material apresenta comportamento elástico linear até o instante em que a tensão de ruptura $\sigma_{t 0}$ é atingida. A falha corresponde ao momento em que as microfissuras do concreto se unem. Isso gera o amolecimento no diagrama tensãodeformação.

Sob compressão uniaxial, o modelo apresenta comportamento linear até atingir a tensão do limite de proporcionalidade $\sigma_{c 0}$. No regime plástico ocorre o endurecimento até a tensão última $\sigma_{c u}$, em seguida ocorre o amolecimento. Na Figura 26 está ilustrado o comportamento do modelo submetido à tração e à compressão uniaxial. 
Figura 26 - Comportamento do modelo: (a)Tracionado (b)Comprimido uniaxialmente
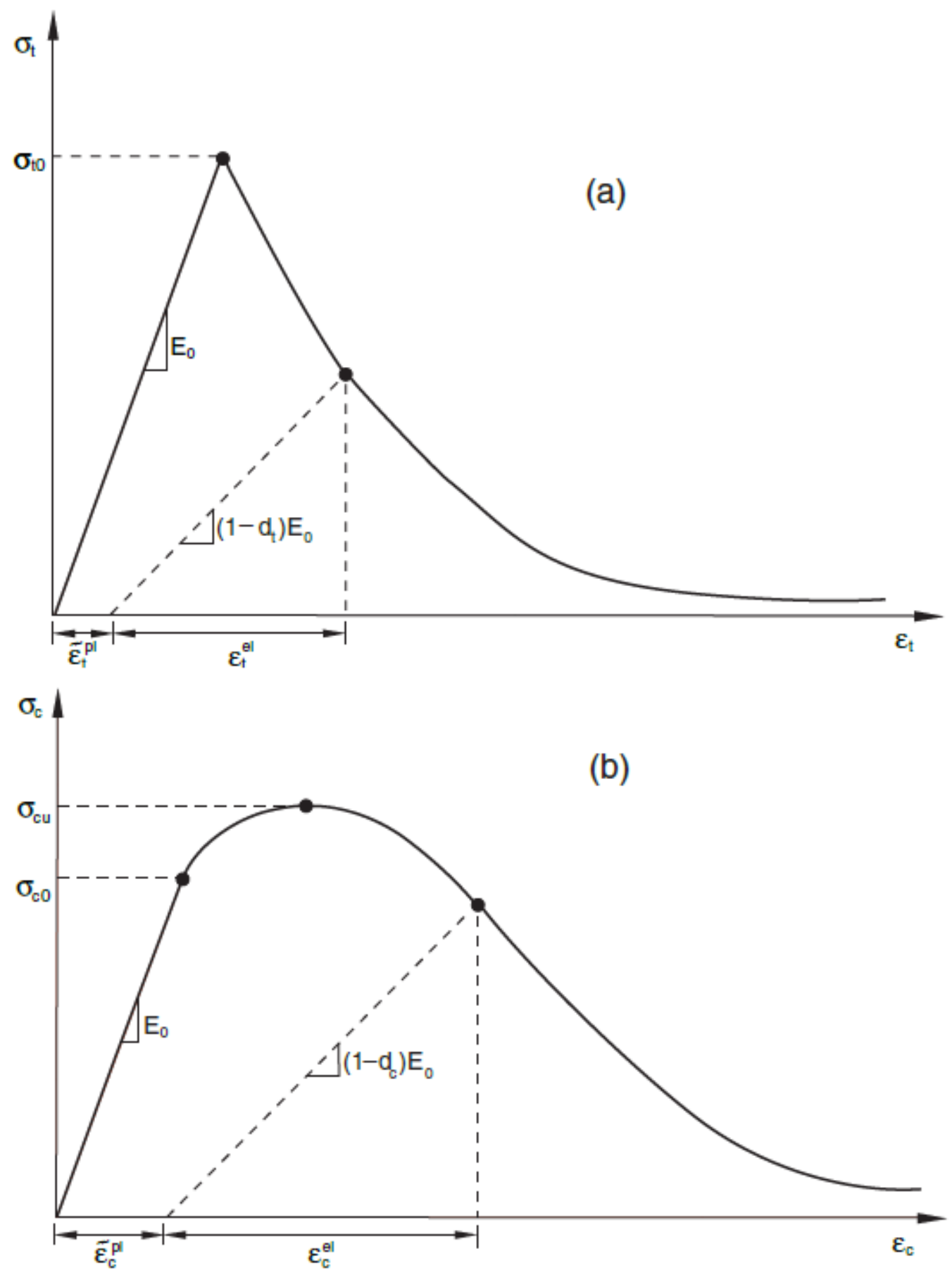

Fonte: Abaqus Analysis (2012)

Se o concreto é carregado até a zona de amolecimento e em seguida descarregado, ele apresenta comportamento enfraquecido, pois o material foi danificado, conforme ilustrado na Figura 26. A degradação do material é definida em função de duas variáveis de dano: $d_{t} \mathrm{e}$ $d_{c}$, dano à tração e à compressão respectivamente, que por sua vez são definidas em função da deformação plástica, temperatura e variáveis de campo. As variáveis de dano podem assumir 
valores de zero a um. Na Figura 26, $\mathrm{E}_{0}$ representa o módulo de elasticidade do material não danificado.

A definição do comportamento do modelo sujeito à compressão é feita fora do regime elástico. Os dados de endurecimentos são fornecidos em termos de deformação inelástica, $\stackrel{\sim}{\stackrel{\text { in }}{\mathcal{E}_{c}}}$ no lugar de deformação plástica, $\stackrel{\sim p l}{\boldsymbol{\varepsilon}_{c}}$. A deformação inelástica de compressão é definida como a deformação total de compressão menos a deformação elástica. O software converte os dados de deformação inelástica em deformação plástica, conforme a Equação 19:

$$
\stackrel{\sim p l}{\mathcal{E}_{c}}=\stackrel{\sim \text { in }}{\mathcal{E}_{c}}-\frac{d_{c}}{\left(1-d_{c}\right)} \frac{\sigma_{c}}{E_{0}}
$$

onde:

$d_{c}$ é a variável de dano à compressão;

$\sigma_{c}$ é a tensão de compressão;

$\mathrm{E}_{0}$ é o módulo de elasticidade.

Outros parâmetros necessários para a utilização deste modelo são:

- Ângulo de dilatância ( $\psi$ ): conforme Cardoso (2014) o material apresentará comportamento frágil com baixos valores e comportamento dúctil para valores mais elevados.

- $\sigma_{b 0} / \sigma_{c 0}$ : razão entre compressão biaxial e uniaxial descreve o comportamento do concreto em estado de compressão biaxial, conforme ilustra a Figura 27. 
Figura 27 - Resistência do concreto em estado biaxial de tensões

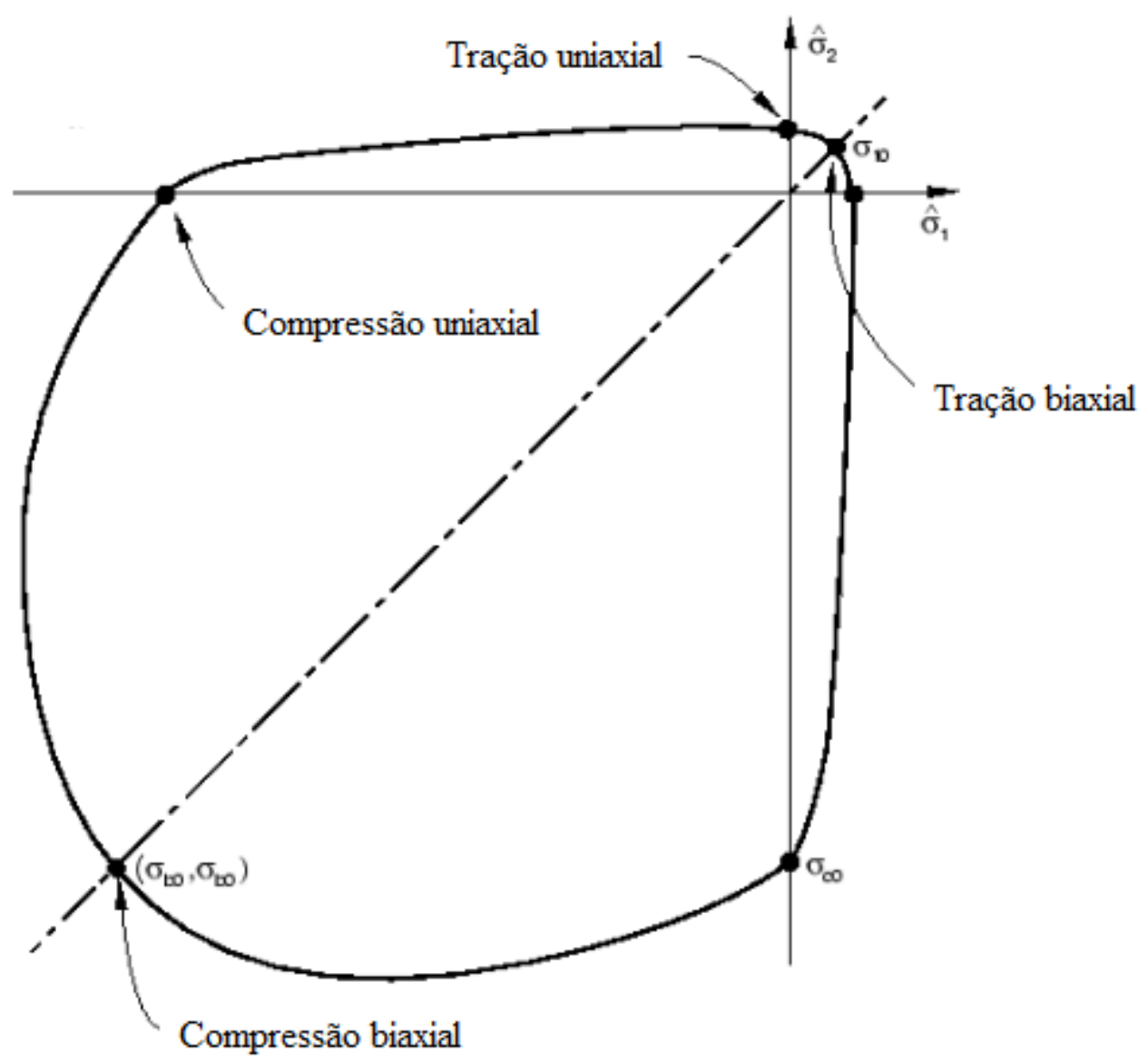

Fonte: Abaqus Analysis (2012)

- Kc: define o formato da superfície de resistência do concreto modificando o critério de Drucker-Prager, conforme mostra a Figura 28. 
Figura 28 - Superfície de resistência para diferentes valores de Kc
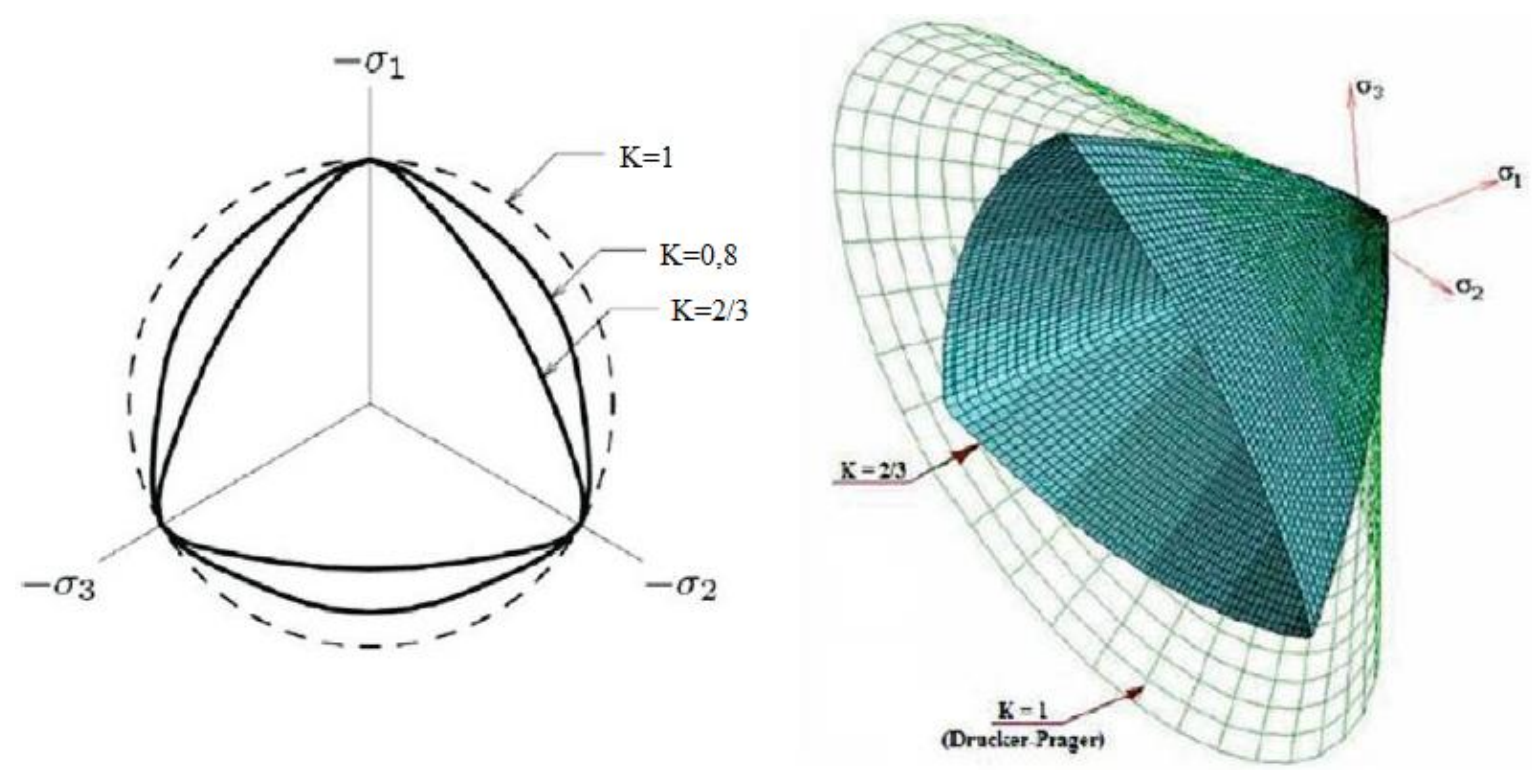

Fonte: Santos et al. (2017)

\subsubsection{Análise térmica}

A análise térmica pode ser feita através do método dos elementos finitos utilizandose diferentes softwares, tais como Diana, Adina, Ansys e Abaqus. De acordo com Wang (2002) esses pacotes comerciais utilizam técnicas similares e partem de hipóteses semelhantes para a solução do problema. Assim, a escolha do software pode ser feita conforme a sua disponibilidade e a aptidão de uso.

Segundo Buchanan (2002) os programas Abaqus, Ansys e Nastran permitem o cálculo de transferência de calor em elementos tridimensionais. Conforme o autor, a deficiência desses programas comerciais é a impossibilidade de simular a transferência de massa, como a migração de vapor de água em materiais porosos. Entretanto, este problema pode ser contornado variando-se as propriedades térmicas do material conforme a mudança de temperatura.

De acordo com FIB 46 (2008), paredes que são aquecidas em apenas uma face apresentam curvatura devido ao gradiente de temperatura e dilatação do material. A laje que se apoia nesta parede expandirá longitudinalmente, aumentando ainda mais a excentricidade do carregamento, como pode ser observado na Figura 29. 
Figura 29 - Curvatura da parede e expansão longitudinal da laje

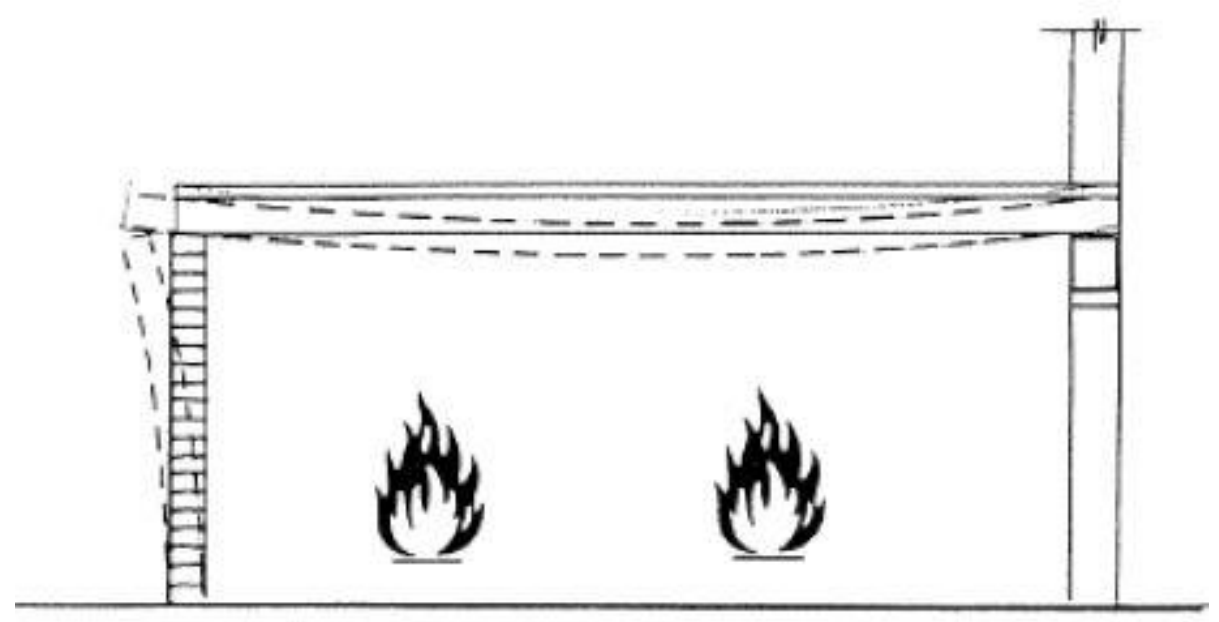

Fonte: FIB 46 (2008)

No software Abaqus é possível representar a expansão térmica por meio do coeficiente de dilatação térmica $\alpha$, que pode variar em função da temperatura. A deformação térmica, $\varepsilon^{\text {th }}$, é calculada por meio do coeficiente de dilatação térmica e a variação de temperatura.

Quando a estrutura tem a expansão restrita, a mudança de temperatura causa variação na tensão. Para elementos unidimensionais e no regime elástico, o problema pode ser resolvido de acordo com a Lei de Hooke, conforme se explicita na Equação 20:

$\sigma_{x}=E\left(\varepsilon_{x}-\varepsilon_{x}^{t h}\right)$

onde:

E é o módulo de elasticidade do material;

$\varepsilon_{x}$ é a deformação total;

$\varepsilon_{x}^{\text {th }}=\dot{\alpha} . \Delta T$ é a deformação térmica.

Conforme o manual do software, no Abaqus a expansão térmica não é considerada no balanço total de energia. Assim, a expansão térmica restrita introduz energia de deformação, que resultará em um aumento da energia total do modelo.

Em modelos não integrados, a análise de resistência ao fogo é feita inicialmente determinando-se o comportamento térmico na forma de distribuição de temperatura dependente do tempo na estrutura, conforme FIB 38 (2007). Com esse resultado é possível 
avaliar apenas o critério de isolamento térmico. Para gerar as tensões e deformações na estrutura, deve ser feita a análise mecânica introduzindo-se o cálculo térmico.

\subsection{ALVENARIA EM SITUAÇÃO DE INCÊNDIO}

Nikolaev (1997) avaliou a distribuição de temperatura em blocos de concreto vibro prensados submetidos às condições de incêndio padrão. Foi feito um modelo no pacote computacional Nikabt, onde os cálculos são baseados no método dos elementos finitos. O critério analisado foi o de isolamento térmico em uma parede formada por duas camadas, com um isolante térmico entre elas, aquecida em apenas uma face. $\mathrm{O}$ modelo matemático de aquecimento obtido pelo autor foi embasado na equação de condução de calor no regime transiente, com coeficientes não lineares e condições de contorno dependentes do tempo. $\mathrm{O}$ autor comparou os resultados obtidos com soluções analíticas e dados de outros autores, tendo concluído que o modelo é adequado para representar o problema em questão.

Nadjai et al. (2003) avaliaram numericamente o comportamento da alvenaria estrutural carregada e em situação de incêndio. Os autores utilizaram o software MasSET baseado no método dos elementos finitos. Inicialmente os autores compararam os resultados numéricos de deslocamento lateral com um experimento no qual se aplicou uma tensão axial constante, permitindo a expansão térmica da alvenaria de blocos cerâmicos e se restringiu lateral e rotacionalmente as extremidades da parede. A parede foi aquecida em apenas uma face, seguindo a curva australiana de elevação de temperatura. Então, os autores ensaiaram duas paredes constituídas por blocos de concreto em meia escala com extremidades também restritas rotacionalmente, onde uma apresentou o encurvamento térmico reverso antes da ruptura. Os autores simularam as paredes em duas dimensões e concluíram que as modelagens representaram bem o comportamento da alvenaria em situação de incêndio, não apresentando, porém o fenômeno do encurvamento térmico reverso, apresentado experimentalmente em uma das paredes. Nadjai et al. (2003) atribuíram essa incoerência à não restrição rotacional empregada na simulação. Conforme os autores, após a rotação da extremidade superior no valor de um ângulo $\theta_{\lim }$ desconhecido, a placa gera um momento devido à restrição rotacional existente.

Nadjai e Ali (2006) estudaram paredes de compartimentação na situação de incêndio. Os autores utilizaram o software MasSET para simular as paredes nas quais se apoiam lajes em concreto armado. Foi modelada em duas dimensões uma parede com blocos cerâmicos, utilizando elementos de interface para conectar a laje à parede. Os autores concluíram que o 
deslocamento horizontal numérico foi consideravelmente inferior ao obtido experimentalmente por outros autores, devido às restrições rotacionais. Nadjai e Ali (2006) também simularam paredes feitas com blocos de concreto com lajes em ambos os lados e em apenas um lado. A elevação de temperatura foi considerada em apenas uma face das paredes e seguiu-se a norma australiana. Os autores concluíram que os modelos escolhidos representam bem o comportamento de paredes reais de alvenaria estrutural na situação de incêndio.

Nahhas et al. (2007) analisaram experimentalmente e por meio de modelagem térmica a resistência ao fogo da parede de alvenaria estrutural constituída por blocos celulares de concreto. Para o experimento, foi utilizado um forno a gás, onde a elevação de temperatura seguiu a curva padrão ISO 834-1:1999. O ensaio durou cerca de seis horas, a temperatura variou de 20 a $1200^{\circ} \mathrm{C}$ e foi aplicada uma carga vertical de $357 \mathrm{kN}$ (13 ton./m) distribuída por uma viga na extremidade superior da parede. Foram medidos os deslocamentos vertical e horizontal em três pontos, sendo os máximos de 25 e $45 \mathrm{~mm}$ respectivamente. Os autores não informaram se ocorreu o colapso da parede ou qual seria o critério de ruptura considerado. $\mathrm{O}$ gráfico de deslocamento vertical conforme o tempo de ensaio não apresenta uma queda, o que talvez pudesse indicar se ocorreu a ruptura da parede. No modelo teórico, para a transferência de calor foram consideradas a condução, a convecção, e a radiação. Nahhas et al. (2007) concluíram que esse modelo gerou resultados razoáveis, comparados aos obtidos experimentalmente para o campo térmico desenvolvido na parede.

Nguyen et al. (2009) analisaram o comportamento de parede não carregada constituída por blocos cerâmicos de argila refratária por meio de modelagem termomecânica. Os autores inicialmente validaram a modelagem térmica comparando a elevação de temperatura numérica e experimental da parede submetida ao incêndio em apenas uma face, avaliando o critério de isolamento térmico. Na modelagem termomecânica Nguyen et al. (2009) compararam os resultados de deslocamento horizontal experimental e numérico. Os autores concluíram que uma modelagem termoelástica é suficiente para representar esse tipo de parede em situação de incêndio, pois seu comportamento é influenciado principalmente pelo decréscimo do módulo de elasticidade conforme ocorre a elevação de temperatura, se diferenciando do modo de ruptura de paredes carregadas.

Ayala (2010) avaliou experimental e numericamente o comportamento de pequenas paredes constituídas por tijolos de concreto leve em elevadas temperaturas. Experimentalmente, as amostras foram aquecidas até as temperaturas de 200, 400, 600, 700 e $800^{\circ} \mathrm{C}$ e então submetidas à compressão com incrementos de força até que fosse alcançada a ruptura. No software Abaqus o autor simulou o comportamento dessas pequenas paredes em 
elevadas temperaturas e submetidas à compressão por meio da micromodelagem simplificada. $\mathrm{O}$ autor concluiu que as temperaturas de $400,600,700$ e $800^{\circ} \mathrm{C}$ provocaram redução de 9,19 , 60 e $83 \%$ respectivamente, da resistência à compressão das pequenas paredes. Além disso, considerou que as modelagens representaram bem o comportamento das paredes em elevadas temperaturas e submetidas à compressão.

Andreini e Sassu (2011) estudaram o comportamento mecânico de painéis de alvenaria sujeitos à ação do fogo. Os autores apresentaram um modelo analítico para prever a resistência mecânica de painéis de alvenaria submetidos à flexo-compressão, juntamente com a ação do fogo em uma face da parede. Primeiramente foi determinada a distribuição de temperatura ao longo da espessura da parede. Isso permitiu determinar a queda de resistência do material e rigidez axial conforme a temperatura. As deformações foram calculadas em função da curvatura. Por último, com base nas isotermas e relações constitutivas de tensãodeformação-temperatura, os autores determinaram a superfície de falha no diagrama M-N. Andreini e Sassu (2011) concluíram que os cálculos indicavam uma melhora no desempenho das paredes quando estas eram submetidas a temperaturas mais elevadas, o que era irreal.

Rosemann (2011) analisou a resistência ao fogo de paredes de alvenaria estrutural de blocos cerâmicos pelo critério de isolamento térmico por meio de experimentos e métodos numéricos. Foram avaliadas paredes com quatro composições diferentes, variando a presença ou ausência de revestimento e preenchimento. A temperatura no interior do forno foi controlada através da curva padrão temperatura-tempo conforme a ISO 834-1:1999. Foi observado que a utilização de revestimento aumentou em $85 \%$ a resistência ao fogo da alvenaria, apesar de apresentar fissuras e arqueamento maior que a parede sem revestimento, devido às diferentes dilatações térmicas de suas faces. $\mathrm{O}$ emprego de revestimento e preenchimento dos principais furos dos blocos com areia elevou em cerca de $280 \%$ a resistência ao fogo da alvenaria, apesar de apresentar fissuração e deslocamento transversal significativo. Assim, a aplicação de carregamento externo provavelmente aumentaria a fissuração e deslocamentos transversais, elevando os efeitos de segunda ordem e podendo provocar a ruína das paredes antes de ser atingida a temperatura limite do critério de isolamento térmico. O critério de estanqueidade se manteve atendido após serem alcançadas as temperaturas limites de isolamento térmico.

Para avaliar a resistência ao fogo das paredes de alvenaria estrutural de blocos cerâmicos com métodos de cálculo, Rosemann (2011) utilizou o método analítico da Brick Industry Association - BIA e o método dos elementos finitos com o programa CAST3M. O BIA (2008) apresenta equações que permitem calcular a espessura equivalente de uma parede, 
ou espessura média de materiais sólidos, para um determinado valor tabelado de resistência ao fogo pelo critério de isolamento térmico. Em média, os resultados obtidos nesse método foram $25 \%$ inferiores aos obtidos experimentalmente. No método dos elementos finitos, o autor utilizou elementos bidimensionais e representou somente um bloco para cada caso. Para o aquecimento das paredes foram consideradas radiação e convecção entre os gases do forno e as faces expostas, e condução entre os materiais sólidos componentes das paredes. A perda de calor para o ambiente externo das faces não expostas ao fogo foi considerada por meio da radiação e da convecção. Rosemann (2011) conseguiu um bom ajuste entre as curvas experimentais e numéricas de aumento de temperatura das faces não expostas ao fogo, sendo o maior erro correspondente a 6,4\% de resistência ao fogo pelo critério de isolamento térmico para a parede com revestimento e com preenchimento.

Nguyen e Meftah (2012) avaliaram experimentalmente o comportamento de paredes de alvenaria estrutural composta por blocos cerâmicos na situação de incêndio. Os autores utilizaram paredes com dimensões de $3 \times 3 \mathrm{~m}^{2}$ e a elevação de temperatura seguiu a curva proposta pela ISO 834-1:1999. Foram analisadas paredes carregadas e não carregadas, três diferentes tipos de blocos e os critérios utilizados foram de isolamento térmico (I), estanqueidade (E) e resistência mecânica $(R)$. O carregamento aplicado nas paredes foi distribuído por meio de uma viga e o controle foi de força, mantendo-se constante durante os ensaios. Nguyen e Meftah (2012) informaram que para o critério R foram medidos os deslocamentos lateral e vertical das paredes, entretanto, apresentaram apenas a variação de deslocamento lateral. Os autores concluíram que a resistência ao fogo das paredes mais finas não carregadas é controlada pelo isolamento térmico, pois não foram observadas falhas estruturais. Na parede com espessura maior que $12 \mathrm{~cm}$ e sem carregamento ocorreu o lascamento, porém o isolamento térmico continuou a ser o primeiro critério a ocorrer falha. Segundo os autores, as paredes carregadas perderam estabilidade devido ao lascamento localizado, que se espalhou através de suas espessuras. Essas paredes ruíram por causa dos efeitos de segunda ordem que foram agravados pelo lascamento. Nesse caso o critério R foi o primeiro a falhar.

Rigão (2012) analisou o comportamento de pequenas paredes de alvenaria estrutural com blocos cerâmicos submetidas à compressão e a temperaturas elevadas. Para isso, caracterizou a argamassa em temperatura ambiente e sob altas temperaturas, o bloco cerâmico submetido à compressão, os prismas em temperatura ambiente e sob elevadas temperaturas e a pequena parede sujeita à compressão e situação de incêndio. A elevação de temperatura não foi controlada de acordo com a curva padrão. Foi avaliada a resistência residual da argamassa 
e o autor constatou que após ser submetida à $900^{\circ} \mathrm{C}$ ela não apresentava nenhuma resistência. Os prismas, após serem expostos à temperatura de $900^{\circ} \mathrm{C}$ apresentaram resistência residual média de aproximadamente 50\%. Foram observados incrementos de carga nas pequenas paredes causados pela dilatação das mesmas e restrições em suas extremidades. As pequenas paredes se mantiveram estanques após o incêndio. Nesse trabalho não foi possível comparar os resultados com as normas de segurança contra incêndio, uma vez que a curva de elevação de temperatura não respeitou a curva-padrão.

Adreini et al. (2014) avaliaram o comportamento mecânico de diferentes materiais submetidos a elevadas temperaturas, que podem ser utilizados na composição da alvenaria estrutural. Para isso, foram moldados corpos de prova cilíndricos em argila, argamassa de duas diferentes classes e quatro tipos de concreto, totalizando cerca de 200 amostras. As amostras foram aquecidas até a temperatura preestabelecida, sem seguir a taxa de elevação de temperatura sugerida pela ISO 834-1:1999. Então, os cilindros foram inseridos em um dispositivo específico para manter a determinada temperatura e em seguida submetidos ao teste de compressão mecânica. Avaliou-se a variação de resistência à compressão, o módulo de elasticidade e a deformação última dos materiais, conforme a elevação de temperatura. Além disso, foram obtidas equações polinomiais que descrevessem essas propriedades mecânicas em função da temperatura. Os resultados obtidos experimentalmente divergiram dos valores propostos no Eurocode 6 Parte 1-2:2005. Uma justificativa sugerida pelos autores seria o fato de que as curvas paramétricas da norma europeia teriam sido calibradas para um tipo específico de unidade, no início do processo normativo.

Russo e Sciarretta (2014) analisaram numericamente a resistência residual à compressão de paredes formadas com tijolos cerâmicos, após serem submetidas ao incêndio. Os autores utilizaram o software Diana e analisaram paredes com quatro diferentes espessuras. O isolamento térmico das paredes expostas à curva ISO 834-1:1999 em apenas uma face foi considerado como critério de parada da análise térmica. Russo e Sciarretta (2014) consideraram que os resultados obtidos de ruptura nas modelagens foram satisfatórios, sendo que a maior redução de resistência foi de $49 \%$ para a parede com $25 \mathrm{~cm}$ de espessura.

Khaliq e Bashir (2016) analisaram as propriedades mecânicas de tijolos cerâmicos em elevadas temperaturas. Para isso, 15 amostras foram ensaiadas com temperaturas variando entre 20 e $800^{\circ} \mathrm{C}$. Os tijolos foram aquecidos em forno elétrico com taxa de aquecimento de $2^{\circ} \mathrm{C} / \mathrm{min}$, mantidos durante 60 minutos em determinada temperatura, envolvidos em uma manta térmica e então submetidos aos ensaios. Foram obtidas as variações de resistência à compressão, resistência à tração e módulo de elasticidade em função da temperatura. Os 
valores de módulo de elasticidade foram calculados com o emprego das curvas tensãodeformação. Os resultados obtidos foram comparados com outros de diversos autores e observou-se certa divergência entre eles. Khaliq e Bashir (2016) assumem que isso ocorreu devido às diferenças na composição, na geometria das amostras e nos procedimentos de ensaio. Os autores concluíram que o decréscimo do módulo de elasticidade inicialmente é elevado e após $200^{\circ} \mathrm{C}$ é gradual. Além disso, notaram que acima de $400^{\circ} \mathrm{C}$ ocorrem transformações mineralógicas, responsáveis pelo aumento da porosidade, fissuração e consequente redução de resistência.

Leite, Moreno Jr. e Torres (2016) efetuaram um estudo sobre os procedimentos de dimensionamento da alvenaria estrutural na situação de incêndio apresentados nas normas americana, australiana e europeia, uma vez que o Brasil não possui normatização vigente. Com o intuito de se adaptarem as normas internacionais à realidade brasileira, os autores sugeriram que inicialmente sejam ensaiados os blocos usuais e com diferentes tipos de acabamentos, levando em conta ao menos o critério de isolamento térmico (I), já que o país carece de equipamentos aptos ao ensaio de paredes carregadas. Por ser o caminho mais rápido, os autores recomendaram que através da simulação numérica fosse feito o mapeamento das isotermas dos blocos. Isso permitiria a avaliação da resistência mecânica (R) da parede em situação de incêndio por meio de cálculo simplificado. Por fim, Leite, Moreno Jr. e Torres (2016) recomendaram que fossem feitos experimentos com paredes de alvenaria carregadas e em situação de incêndio, permitindo a construção de ábacos e reunindo informações necessárias à primeira normatização nacional. Essas medidas devem ser adotadas, pois segundo os autores, cada país dispõe de especificações de espessura, capacidade resistente e geometria a serem seguidas, além das diferentes composições mineralógicas dos agregados utilizados na fabricação dos blocos.

Rocha (2016) avaliou experimental e numericamente o comportamento de pilares de aço e mistos de aço e concreto inseridos em paredes em situação de incêndio. Para a análise numérica foi utilizado o software Abaqus na versão 6.14. As paredes foram simplificadas como um bloco retangular de mesma altura do pilar, não sendo representadas as juntas de argamassa e as cavidades dos blocos para diminuir os esforços computacionais. Como propriedade mecânica foi considerada apenas o módulo de elasticidade, sem efeito de degradação mecânica. As propriedades térmicas, calor específico e condutividade térmica, foram consideradas constantes com a temperatura e foram empregados valores próximos aos utilizados para o concreto. Segundo o autor, não foi possível obter um modelo que descrevesse o comportamento dos pilares junto às paredes. A influência das paredes na 
rigidez total do pilar não foi observada na simulação, como ocorreu experimentalmente. $\mathrm{O}$ autor enfatizou a dificuldade de se representar a parede de forma completa.

Russo e Sciarretta (2016) analisaram através do método dos elementos finitos as propriedades mecânicas de diferentes unidades, durante e após terem sido submetidas ao incêndio. Foram simulados blocos cerâmicos com diferentes porcentagens de aberturas, por meio do software Diana. Os autores simplificaram a análise utilizando o mesmo modelo de bloco para todas as simulações, apenas adaptando a condutividade térmica conforme a porcentagem de vazios. Segundo os autores, os modelos numéricos com condutividade térmica equivalente representaram satisfatoriamente o comportamento das unidades. Russo e Sciarretta (2016) concluíram que unidades vazadas possuem resistência ao fogo menor que as unidades sólidas. Eles destacaram que o elevado isolamento térmico em temperatura ambiente das unidades vazadas não existe em elevadas temperaturas. Isso ocorre em razão da transmissão de calor por radiação dentro das cavidades.

Ao observar esses trabalhos nota-se a falta de estudos relacionados à alvenaria composta por blocos de concreto em situação de incêndio. A maior parte das pesquisas foi realizada no exterior, confirmando a escassez de informações sobre a alvenaria estrutural brasileira em elevadas temperaturas. Percebe-se ainda que o isolamento térmico geralmente é o primeiro critério de resistência a falhar na alvenaria. Nos trabalhos onde foram analisados os três critérios de resistência ao incêndio, as paredes se mantiveram estanques até a perda de estabilidade. 


\section{SIMULAÇÕES DE COMPRESSÃO EM TEMPERATURA} AMBIENTE

\subsection{SIMULAÇÃO DO BLOCO DE CONCRETO SUJEITO À COMPRESSÃO EM TEMPERATURA AMBIENTE}

A caracterização mecânica do bloco de concreto considerado na simulação foi realizada no Laboratório de Estruturas da Escola de Engenharia de São Carlos - USP por Oliveira (2014). Através dos ensaios eles foram caracterizados como classe de resistência A como especifica a Tabela 2 da ABNT NBR 6136:2016, com $\mathrm{f}_{\mathrm{bk}}$ de 8,68 MPa na área bruta.

As dimensões externas médias do bloco obtidas por Oliveira (2014) foram utilizadas na simulação. O interior do bloco foi simplificado substituindo por arestas as mísulas curvas. Assim, as dimensões das paredes do bloco foram estimadas de modo que a média de área superior e inferior resultasse o mais próximo do valor de área líquida de $297,95 \mathrm{~cm}^{2}$, uma vez que suas cavidades possuem forma de tronco de pirâmide. As dimensões empregadas na simulação são apresentadas na Figura 30. 
Figura 30 - Dimensões do bloco de concreto utilizadas na simulação (mm)
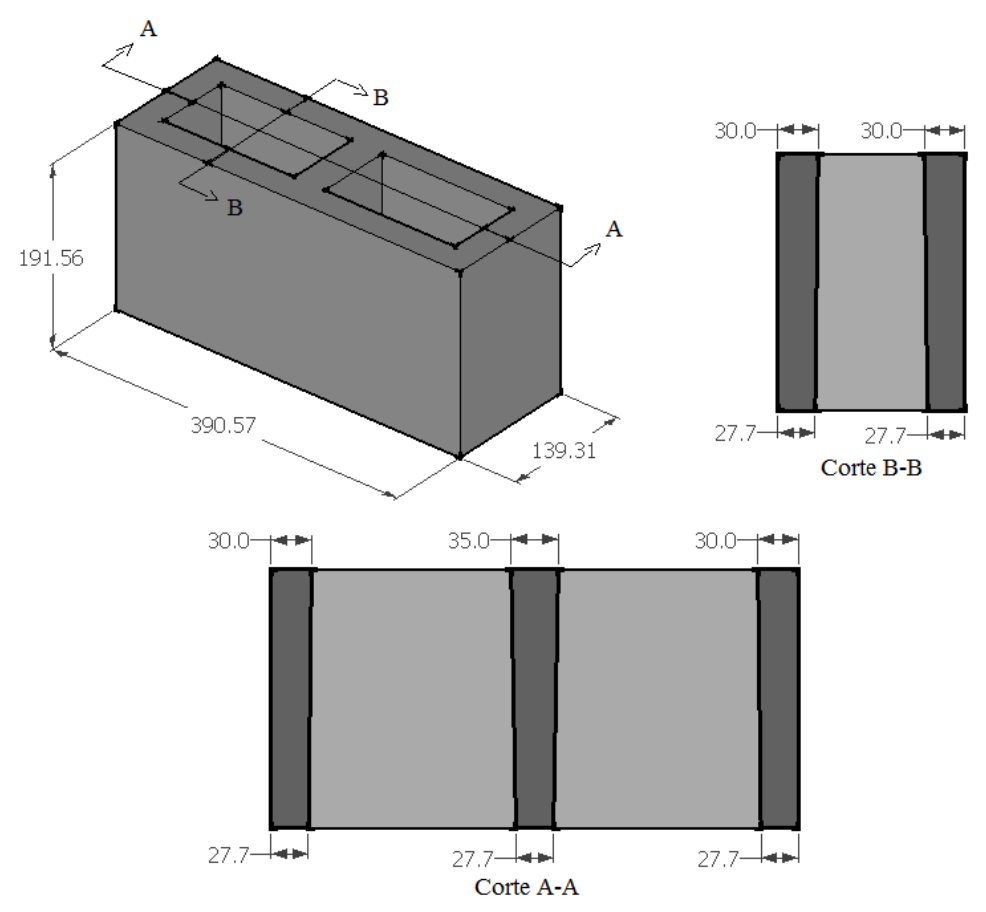

Fonte: Autora (2018)

Com essas dimensões obteve-se a área líquida de $297,89 \mathrm{~cm}^{2}$. No bloco de concreto foram utilizados 6080 elementos sólidos pertencentes à família "tensão-3D” do tipo C3D8R, elementos de oitos nós e três graus de liberdade, com lados de dimensões aproximadas de 1 cm e integração reduzida. A ilustração da malha utilizada no bloco encontra-se na Figura 31.

Figura 31 - Malha utilizada no bloco de concreto

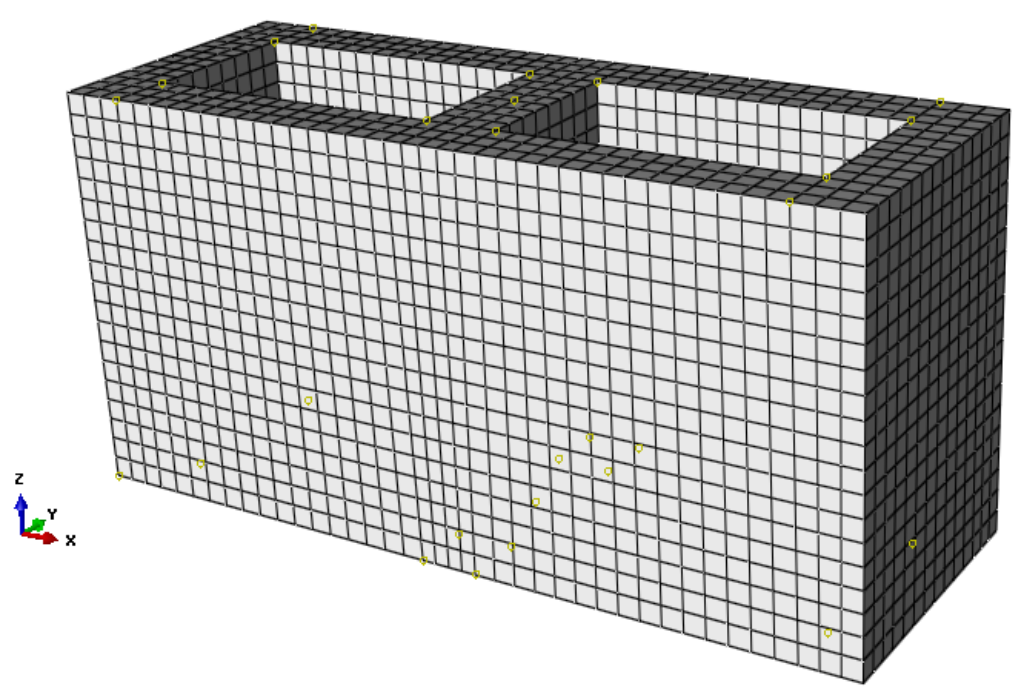

Fonte: Autora (2018) 
O módulo de elasticidade do concreto foi calculado por meio da curva tensãodeformação obtida com clip-gages, disponível em Oliveira (2014). Foi traçada a linha de tendência no software Excel no regime linear, entre 5 e $33 \%$ da tensão de ruptura do bloco, obtendo-se $20141 \mathrm{MPa}$. Adotou-se 0,2 como coeficiente de Poisson e utilizou-se o modelo de plasticidade do software Abaqus Concrete damaged plasticity.

A curva tensão-deformação inserida no software foi a proposta por Carreira e Chu (1985) expressa na Equação 21:

$\frac{\sigma_{c}}{\sigma_{c}^{\prime}}=\frac{\beta\left(\varepsilon / \varepsilon_{c}^{\prime}\right)}{\beta-1+\left(\varepsilon / \varepsilon_{c}^{\prime}\right)^{\beta}}$

onde:

$\beta=\frac{1}{1-\frac{\sigma_{c}^{\prime}}{\varepsilon_{c}^{\prime} E_{t}}} ;$

$\sigma_{c}^{\prime}$ é a resistência à compressão do concreto;

$\varepsilon_{c}^{\prime}$ é a deformação correspondente à máxima tensão no concreto;

$E_{t}$ é o módulo de elasticidade tangente inicial do concreto.

No modelo de Carreira e Chu (1985) foram inseridos os valores de 18,5 MPa de resistência à compressão, 3\%o de deformação de pico e $20141 \mathrm{MPa}$ de módulo de elasticidade, obtidos por meio da curva tensão-deformação calculada para a área líquida do bloco.

$\mathrm{O}$ dano à compressão foi calculado conforme a Equação 22 disponível em Birtel e Mark (2006):

$d_{c}=1-\frac{\sigma_{c} / E_{t}}{\varepsilon_{c}^{p l}\left(1 / b_{c}-1\right)+\sigma_{c} / E_{t}}$

onde:

$b_{c}$ foi adotado igual a 0,7 ;

$\varepsilon_{c}^{p l}=b_{c} \cdot \varepsilon_{c}^{i n}$.

A resistência à tração obtida experimentalmente para o bloco foi considerada baixa conforme a literatura, assim, optou-se por adotar 0,96 $\mathrm{MPa}$, valor empregado por Oliveira (2014) em suas simulações. O comportamento à tração foi inserido no Abaqus através da 
energia de fratura na tração. A energia de fratura $(\mathrm{N} / \mathrm{mm})$ foi calculada conforme sugere CEBFIP MC 1990 apud FIB (2013) disposto na Equação 23, indicada para diâmetro máximo do agregado de $8 \mathrm{~mm}$, obtendo-se aproximadamente $0,04 \mathrm{~N} / \mathrm{mm}$ ou $40 \mathrm{~N} / \mathrm{m}$ :

$$
G_{f I}=0,025\left(\frac{f_{c}^{\prime}}{10}\right)^{0,7}
$$

onde:

$f_{c}^{\prime}$ é a resistência à compressão do concreto em MPa.

O restante dos parâmetros do material, necessários para o modelo de plasticidade do software, foi calibrado para se obter o resultado numérico mais próximo do experimental. Estes parâmetros estão dispostos na Tabela 10.

Tabela 10 - Parâmetros do bloco necessários para o modelo de plasticidade

\begin{tabular}{ccccc}
\hline $\begin{array}{c}\text { Ângulo de } \\
\text { dilatância }\end{array}$ & Excentricidade & $\sigma_{b 0} / \sigma_{c 0}$ & Kc & Viscosidade \\
\hline 27 & 0,1 & 1,14 & 0,666 & 0,0001 \\
\hline
\end{tabular}

Fonte: Autora (2018)

Para aplicar a compressão no bloco foram discretizadas duas placas, uma que serviu de apoio acoplada a um nó de referência com todos os graus de liberdade restritos, e outra na qual se restringiram os deslocamentos nos eixos $\mathrm{X}$ e $\mathrm{Y}$, e se aplicou deslocamento de $1 \mathrm{~mm}$ em pequenos incrementos no eixo $\mathrm{Z}$, gerando a compressão do bloco.

Cada placa foi elaborada com dimensões de $42 \times 15 \mathrm{~cm}^{2}$, espessura de $3 \mathrm{~cm}$ e 1890 elementos do mesmo tipo do bloco. Para simular um material rígido empregou-se elevado módulo de elasticidade, se comparado ao valor atribuído ao concreto, e coeficiente de Poisson nulo.

No contato entre as placas e o bloco de concreto foi atribuída ao comportamento normal a opção "Hard contact", que praticamente impossibilita a penetração de um material em outro, com a opção de permitir a separação após o contato. Já no comportamento tangencial foi inserido o coeficiente de atrito de 0,5 , conforme indica o manual da Rudloff (2015) para contato entre aço e concreto. Na Figura 32 está representado o esquema de compressão do bloco. Os seguimentos de reta amarelos indicam o acoplamento entre os graus de liberdade da placa inferior e o nó de referência. 
Figura 32 - Esquema de compressão do bloco

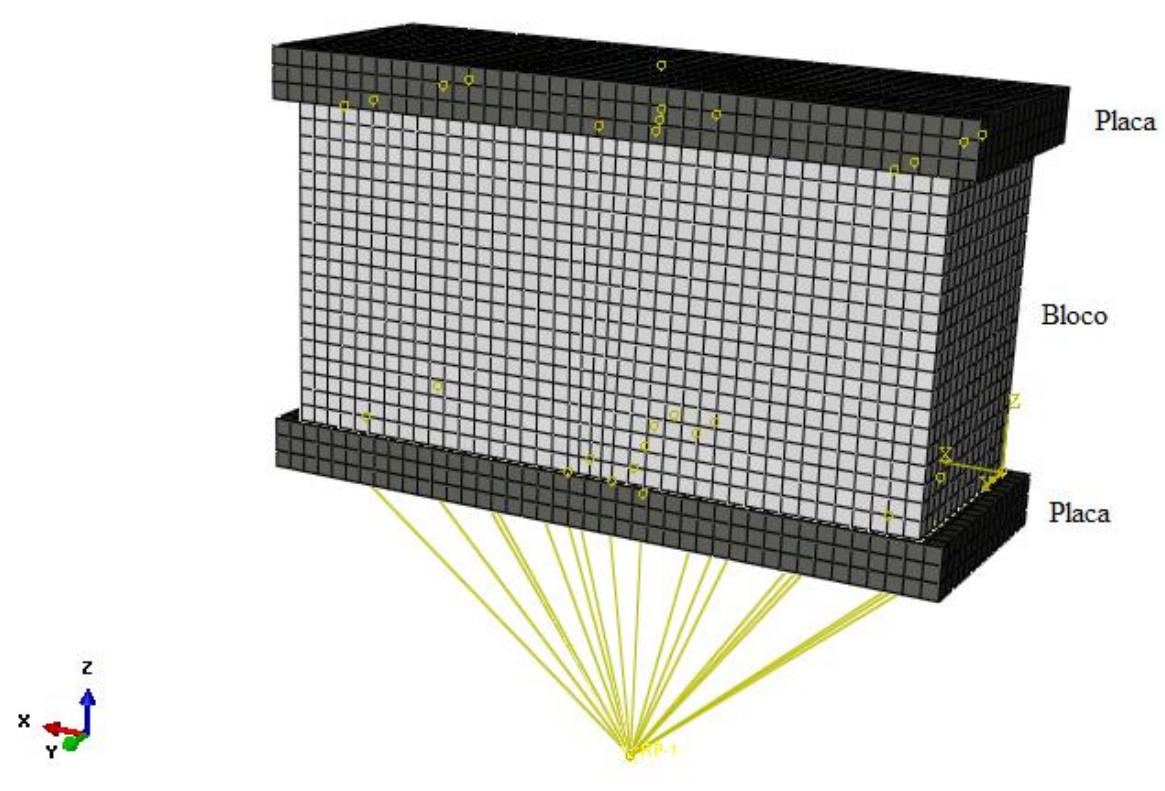

Fonte: Autora (2018)

\subsubsection{Resultados e comparações}

A resistência média à compressão do bloco foi obtida por Oliveira (2014) através de ensaios de seis blocos com controle de deslocamento. Para medir as deformações e possibilitar o traçado dos diagramas tensão-deformação dos blocos, acoplaram-se clip-gages nas faces dos blocos e transdutores de deslocamento entre as placas de compressão, conforme ilustra a Figura 33.

Figura 33 - Ensaio de compressão do bloco de concreto

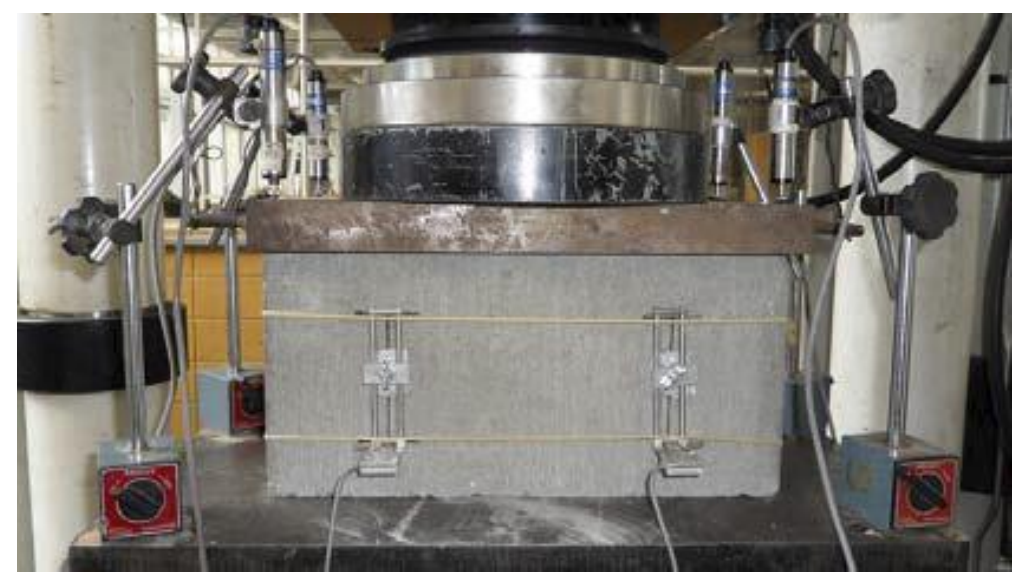

Fonte: Oliveira (2014) 
Os diagramas elaborados com resultados dos transdutores apresentaram uma irregularidade inicial ocorrida devido à acomodação entre as superfícies de contato das chapas e o bloco. A Figura 34 apresenta os diagramas tensão-deformação média dos blocos referente à área líquida, calculada com a razão (área líquida)/(área bruta) igual a 54,76\%.

Figura 34 - Tensão-deformação média dos blocos de concreto na área líquida

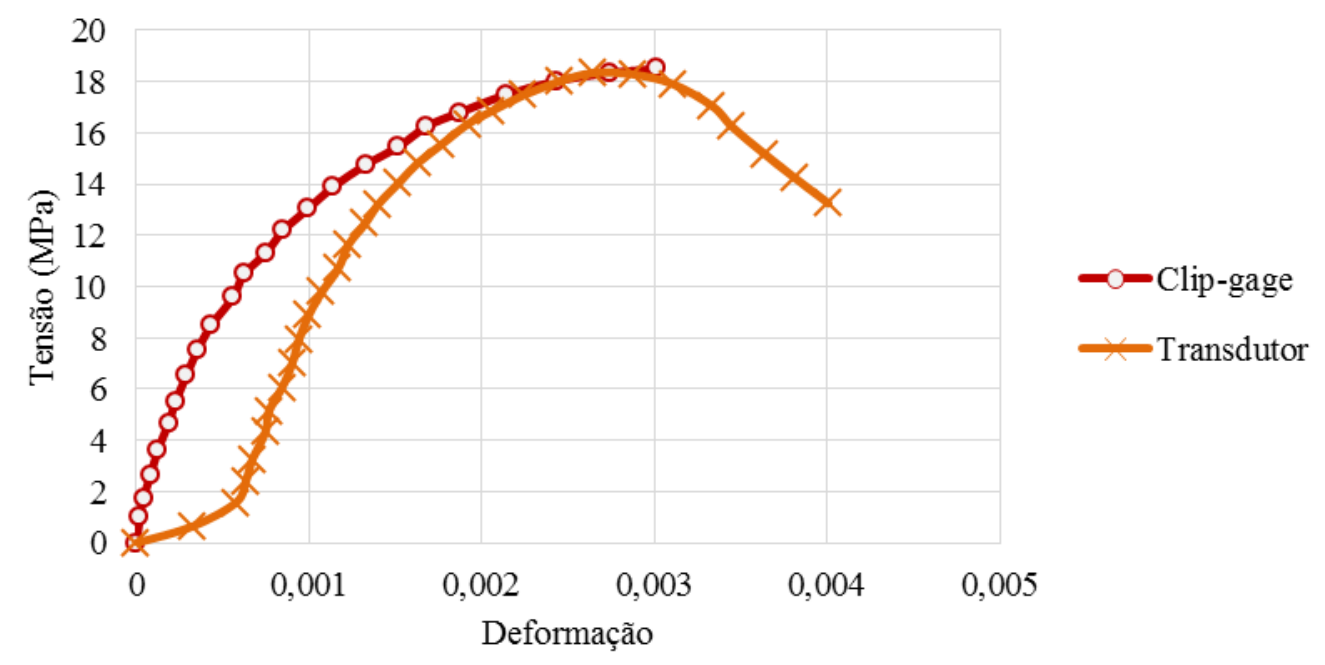

Fonte: Adaptado de Oliveira (2014)

Observa-se que com os clip-gages não foi obtida a parte de amolecimento do diagrama, após a ruptura dos blocos. A irregularidade inicial do diagrama obtido por meio do transdutor foi corrigida prolongando a parte linear e transladando-o para a origem.

Para o cálculo de deformação da modelagem numérica, mediu-se o deslocamento em um nó da extremidade na parte superior do bloco e outro na parte inferior, considerando a posição de um dos transdutores, e se dividiu a diferença entre esses valores pela altura inicial do bloco. Calculou-se também a deformação do bloco em local semelhante à posição de um dos clip-gages. A tensão foi calculada dividindo-se a força obtida em cada incremento de deslocamento pela área líquida. A Figura 35 apresenta os resultados de tensão-deformação na área líquida do bloco de concreto obtidos com o transdutor ajustado, com clip-gage e numericamente. 
Figura 35 - Comparação dos diagramas tensão-deformação do bloco na área líquida

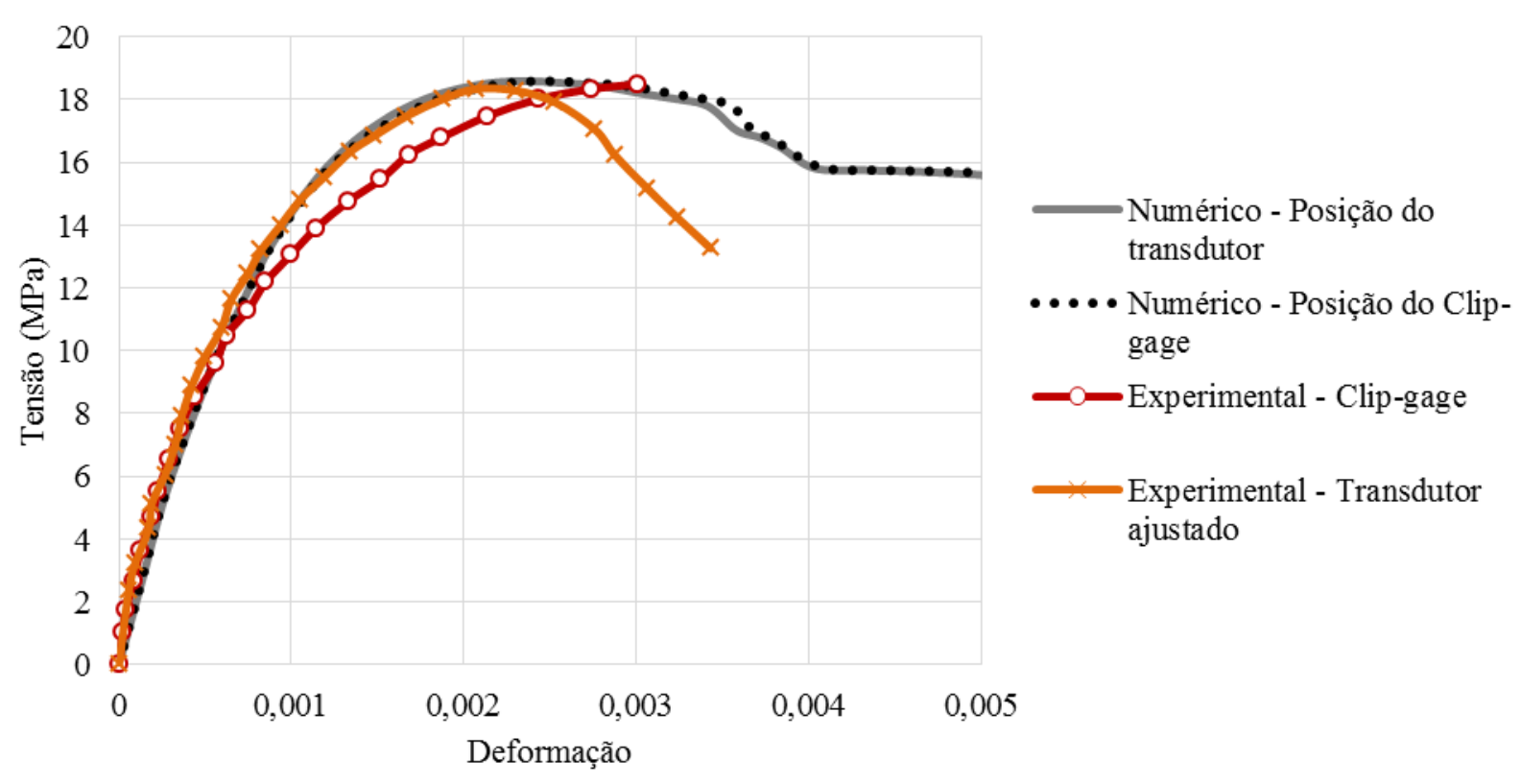

Fonte: Autora (2018)

Nota-se que os resultados numéricos de tensão-deformação do bloco na posição do transdutor e na posição do clip-gage são praticamente os mesmos, ficando bem próximos ao obtido com o transdutor ajustado, ocorrendo uma divergência após a tensão máxima. A máxima força atingida numericamente foi de $553,86 \mathrm{kN}$, gerando a tensão de 18,59 MPa na área líquida, correspondente a um erro de $0,49 \%$ em relação ao valor de 18,50 MPa. A deformação equivalente à força máxima foi de 0,0024 , obtida para o deslocamento de 0,47 mm da placa superior.

Na Tabela 11 estão disponíveis os valores de tensão obtidos através do ajuste dos resultados do transdutor e modelagem numérica na posição do transdutor para deformações em comum.

Tabela 11 - Valores de tensão no bloco de concreto

\begin{tabular}{cccc}
\hline$\varepsilon$ & $\begin{array}{c}\text { Transdutor ajustado } \\
\sigma(\mathrm{MPa})\end{array}$ & $\begin{array}{c}\text { Numérico } \\
\sigma(\mathrm{MPa})\end{array}$ & $\begin{array}{c}\text { Diferença } \\
(\mathrm{MPa})\end{array}$ \\
\hline 0,0002 & 5,14 & 5,04 & 0,10 \\
0,0004 & 8,87 & 7,10 & 1,77 \\
0,0008 & 13,20 & 12,66 & 0,54 \\
0,0012 & 15,53 & 15,86 & 0,33 \\
0,0017 & 17,48 & 17,87 & 0,39 \\
0,0028 & 17,04 & 18,40 & 1,36 \\
0,0032 & 14,23 & 18,02 & 3,79 \\
\hline \multicolumn{4}{c}{ Fonte: Autora (2018) }
\end{tabular}


Os valores de tensão-deformação foram adquiridos do trabalho de Oliveira (2014) com o uso do software Web Plot Digitizer 3.8, no qual os pontos são selecionados manualmente. Isso dificultou a seleção de intervalos iguais de deformação, justificando o espaçamento sem regularidade da Tabela 11. Dentre os valores analisados observa-se que a maior diferença de tensão ocorreu para a deformação final de 0,0032 , correspondendo a um erro de $26,6 \%$. Para o restante dos pontos a diferença de tensão foi pequena.

A Figura 36 apresenta a distribuição de tensões principais máximas no bloco de concreto no instante de força máxima, correspondente ao deslocamento de $0,47 \mathrm{~mm}$ da placa de compressão, além de um corte em um dos planos de simetria permitindo a visualização das tensões nas cavidades do bloco.

Figura 36 - Distribuição de tensões principais máximas no bloco (Pa)
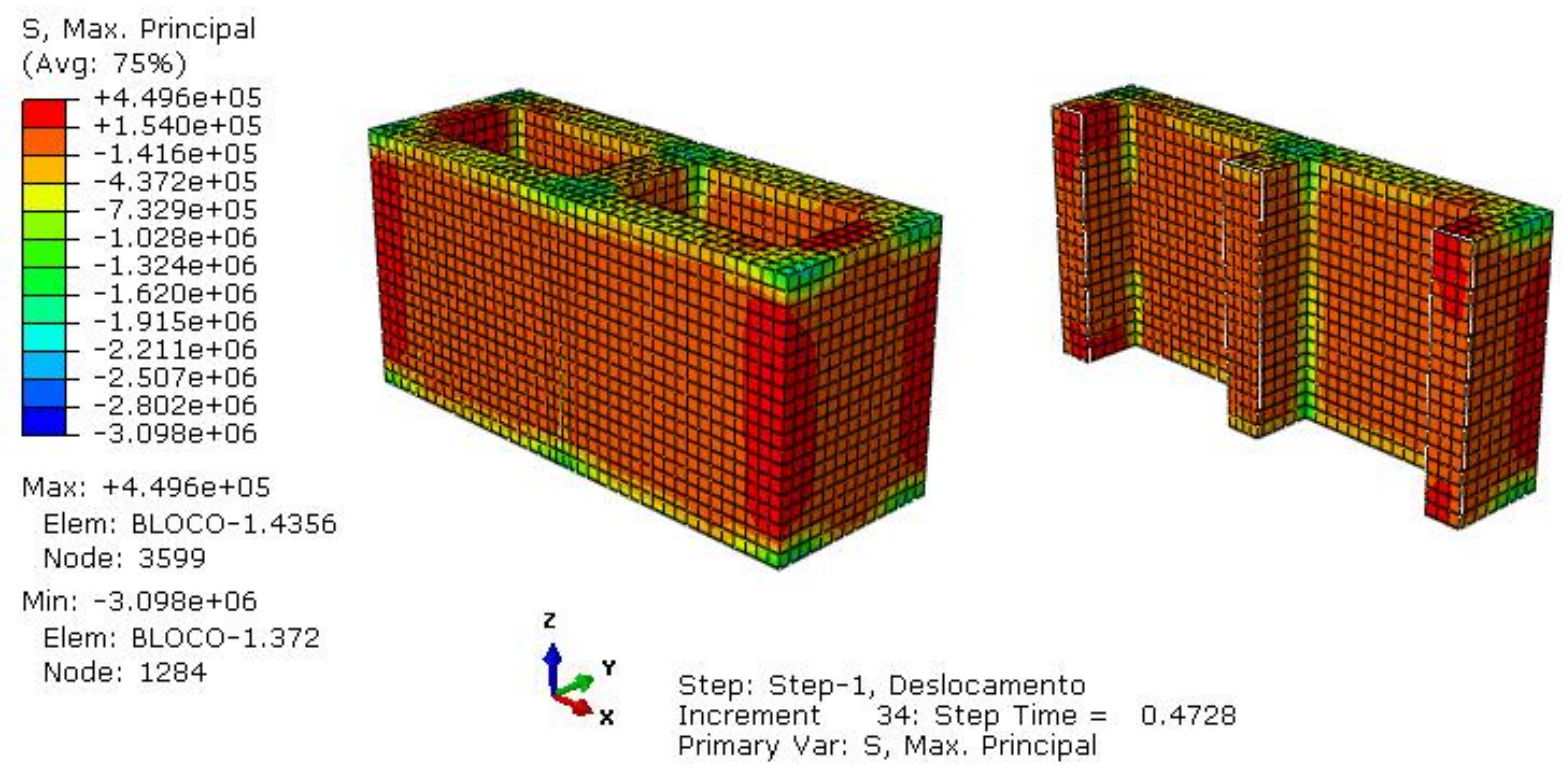

Fonte: Autora (2018)

Na Figura 37 está disposta a distribuição de tensões principais mínimas no bloco, também no instante de força máxima. 
Figura 37 - Distribuição de tensões principais mínimas no bloco (Pa)
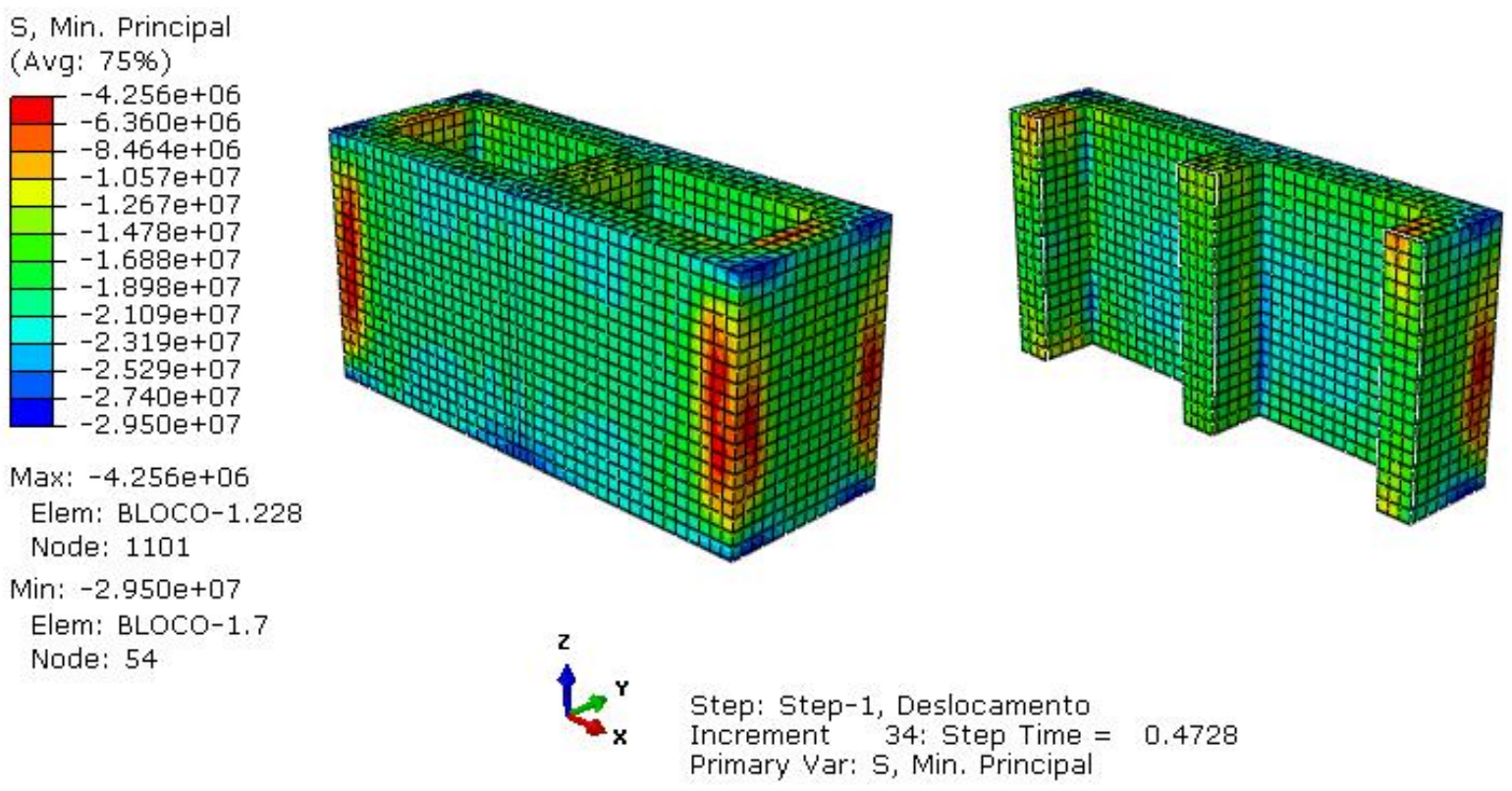

Fonte: Autora (2018)

Observa-se que as regiões com maiores tensões de compressão são as extremidades do bloco, que ficam em contato com as placas. A Figura 38 apresenta o modo de ruptura do bloco de concreto obtido experimentalmente por Izquierdo (2015) e Oliveira (2014), pois ambas utilizaram o mesmo lote de blocos em seus trabalhos.

Figura 38 - Modo de ruptura do bloco de concreto
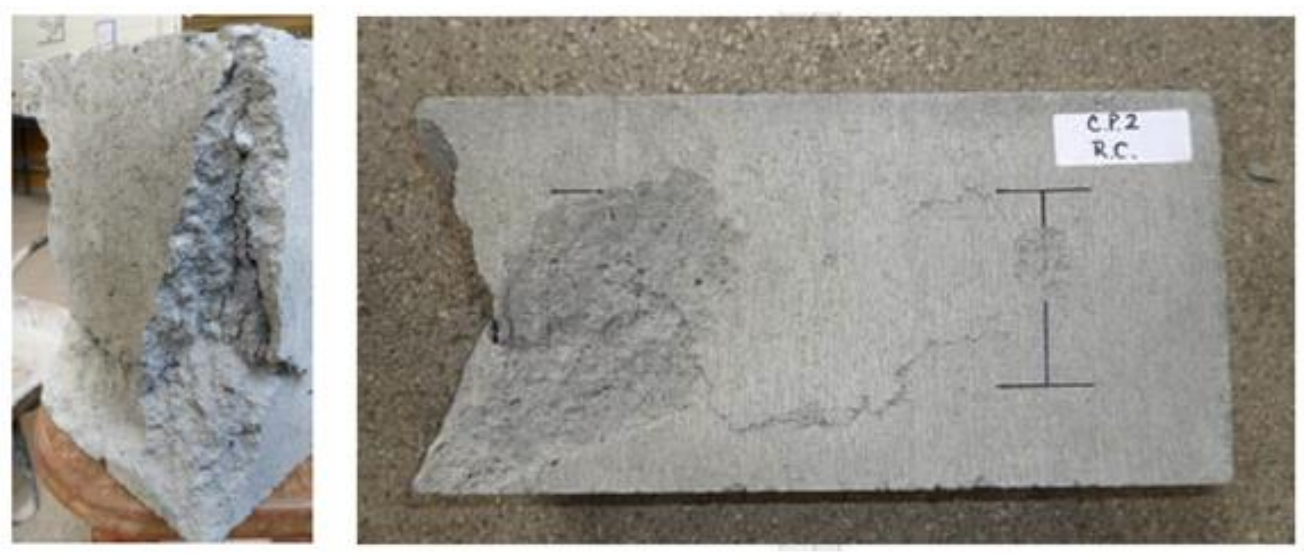

Fonte: Izquierdo (2015) e Oliveira (2014)

Nota-se que o posicionamento dos maiores valores de tensão principal máxima (cor vermelha) na Figura 36 é o mesmo onde ocorre a ruptura do bloco na Figura 38. O modo de 
ruptura experimental e o numérico foram influenciados pelo confinamento produzido pelo atrito entre as placas e o bloco de concreto.

\subsection{SIMULAÇÕES DOS PRISMAS COM BLOCOS DE CONCRETO SUJEITOS À COMPRESSÃO EM TEMPERATURA AMBIENTE}

Os prismas foram produzidos a partir do bloco já validado com a adição da junta de argamassa, gerando a micromodelagem. Inicialmente foi simulado um prisma de três blocos com argamassamento parcial possibilitando a validação dos parâmetros necessários com resultados disponíveis em Oliveira (2014). Em seguida foram feitos os prismas com três blocos e argamassamento total, com dois blocos e argamassamento parcial e com dois blocos e argamassamento total.

A argamassa utilizada por Oliveira (2014) foi do tipo i com traço em volume (cimento : cal : areia) de 1:0,5:4,5, traço em massa de 1:0,33:6,38 e fator água/cimento de 1,17. As dimensões foram definidas de modo que a superfície superior da argamassa se adequasse à base do bloco, sua superfície inferior se acomodasse ao topo do bloco e $1 \mathrm{~cm}$ de espessura. Os elementos utilizados foram do tipo C3D8R com dimensões dos lados próximas de $1 \mathrm{~cm}$. Empregaram-se 260 elementos no argamassamento parcial e 320 no argamassamento total conforme ilustra a Figura 39.

Figura 39 - Malhas utilizadas nas argamassas
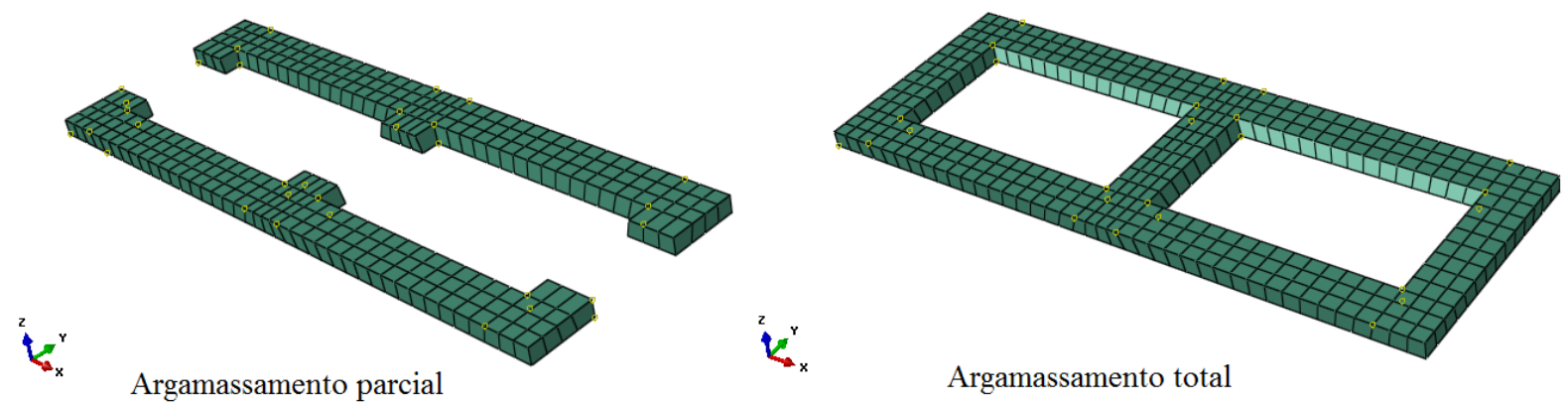

Fonte: Autora (2018)

Aplicaram-se as mesmas propriedades às duas modelagens de argamassa. O módulo de elasticidade utilizado foi de 11,39 $\mathrm{GPa}, 6,93 \mathrm{MPa}$ de resistência à compressão e deformação de pico de 1,85\%, resultados disponíveis em Oliveira (2014). Esses valores 
também foram inseridos no modelo de Carreira e Chu (1985) para a obtenção da curva tensãodeformação, a qual foi introduzida no modelo Concrete damaged plasticity do software Abaqus.

O dano à compressão da argamassa foi calculado conforme a Equação 22. Em Oliveira (2014) não se encontrou ensaios de resistência à tração da argamassa. Então, utilizouse para esse dado a média dos valores da razão (resistência à tração)/(resistência à compressão) aos 28 dias, disponíveis na Tabela 4, e calculou-se a resistência à tração conforme a resistência à compressão da argamassa. Sendo a média da razão (resistência à tração)/(resistência à compressão) de $12,40 \%$ e a resistência à tração da argamassa de 0,86 MPa.

A energia à fratura na tração foi adotada como 50 N/m, conforme Izquierdo (2015). O restante dos parâmetros necessários ao modelo de plasticidade foi calibrado para a obtenção de resultado numérico mais próximo do experimental. Na Tabela 12 estão presentes estes parâmetros.

Tabela 12 - Parâmetros da argamassa necessários para o modelo de plasticidade

\begin{tabular}{ccccc}
\hline $\begin{array}{c}\text { Ângulo de } \\
\text { dilatância }\end{array}$ & Excentricidade & $\sigma_{b 0} / \sigma_{c 0}$ & $\mathrm{Kc}$ & Viscosidade \\
\hline 35 & 0,1 & 1,4 & 0,667 & 0,01 \\
\hline \multicolumn{4}{c}{ Fonte: Autora (2018) }
\end{tabular}

O coeficiente de atrito empregado entre as placas e os blocos foi de 0,6. Esse valor foi modificado em relação ao anterior de 0,5 , pois no caso da compressão de prismas é realizado o capeamento da superfície do bloco que ficará em contato com a placa.

Os blocos e juntas de argamassa foram unidos através da restrição tie. Essa restrição vincula o deslocamento do nó de um elemento ao nó de outro elemento. Essa simplificação foi adotada, pois na ruptura à compressão dos prismas não se observou o descolamento da interface argamassa/bloco. Para a aplicação da compressão impôs-se o deslocamento de $2 \mathrm{~mm}$ na placa superior em pequenos incrementos.

Na Figura 40 é apresentado o esquema de compressão dos prismas de três blocos com argamassamento parcial e total. 
Figura 40 - Esquema de compressão dos prismas de três blocos

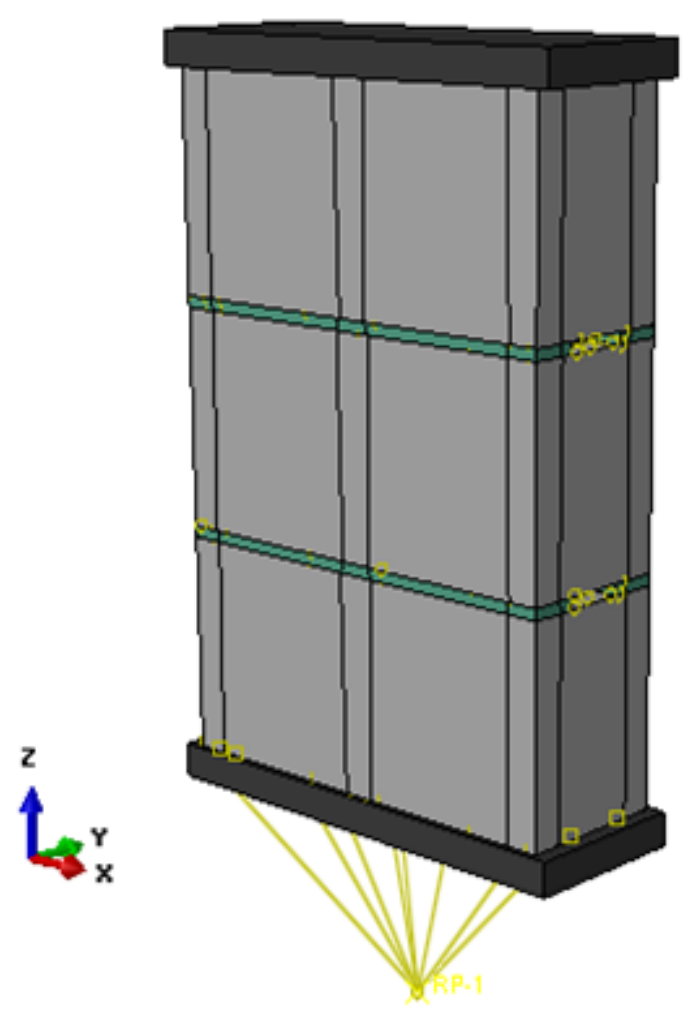

Argamassamento parcial

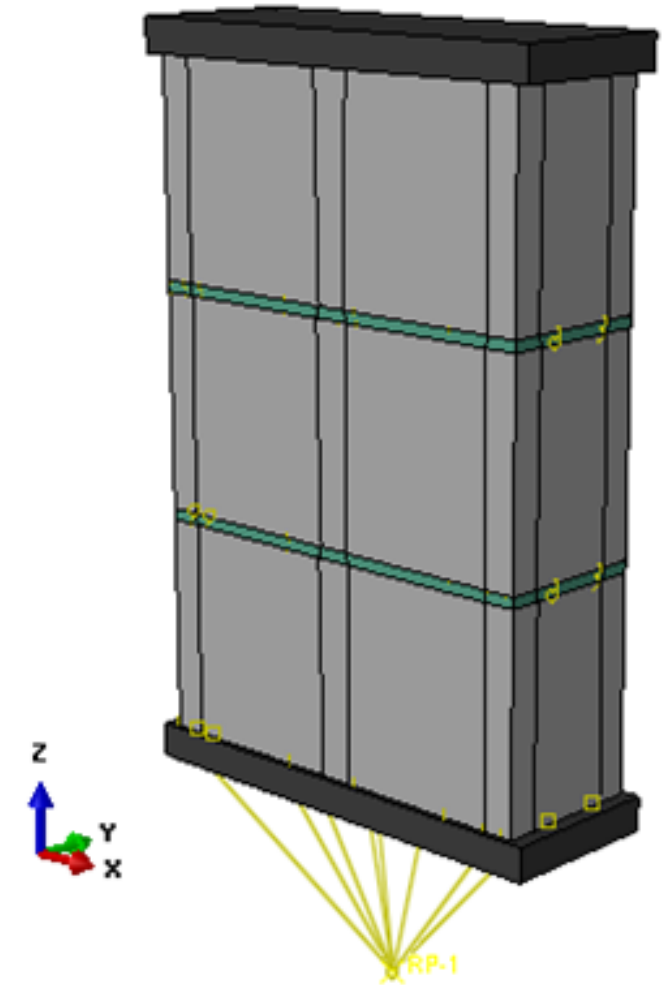

Argamassamento total

Fonte: Autora (2018)

O esquema de compressão dos prismas de dois blocos com argamassamento parcial e total está ilustrado na Figura 41. 
Figura 41 - Esquema de compressão dos prismas de dois blocos

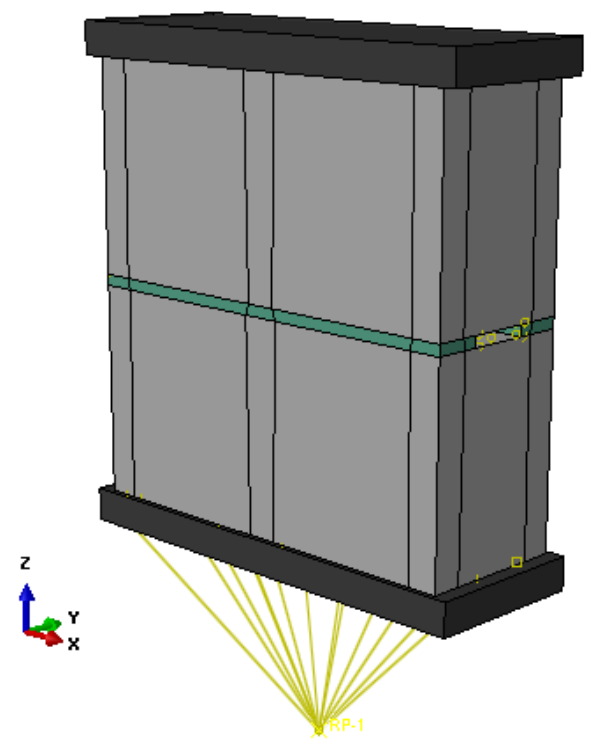

Argamassamento parcial

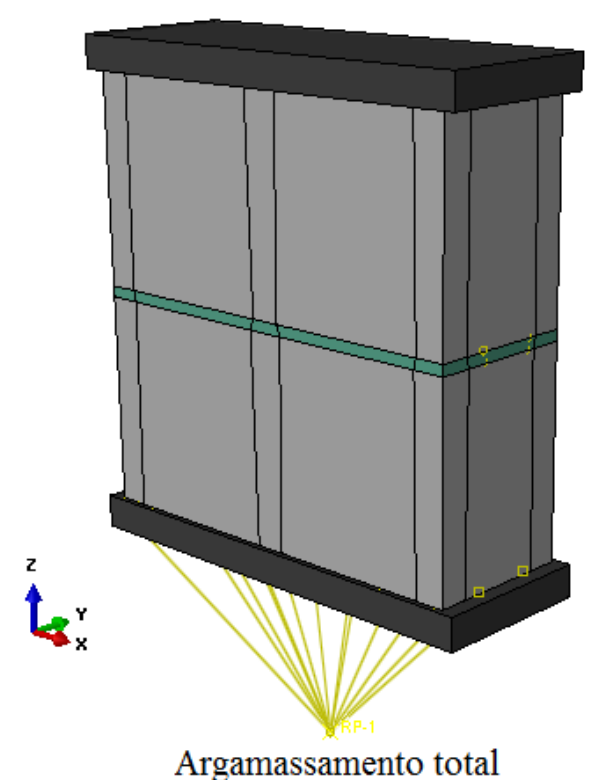

Argamassamento total

Fonte: Autora (2018)

Optou-se por simular os prismas de três e de dois blocos com argamassamento total e parcial para verificar se os resultados de resistência à compressão estavam condizentes com a realidade.

\subsection{Resultados e comparações}

No ensaio de compressão dos prismas de três blocos com argamassamento parcial, Oliveira (2014) utilizou quatro transdutores, sendo dois acoplados em cada face do prisma, para a medição das deformações. Na Figura 42 é possível observar o posicionamento dos transdutores e o capeamento realizado na superfície dos blocos em contato com as placas de compressão. 
Figura 42 - Ensaio de compressão do prisma de três blocos com argamassamento parcial

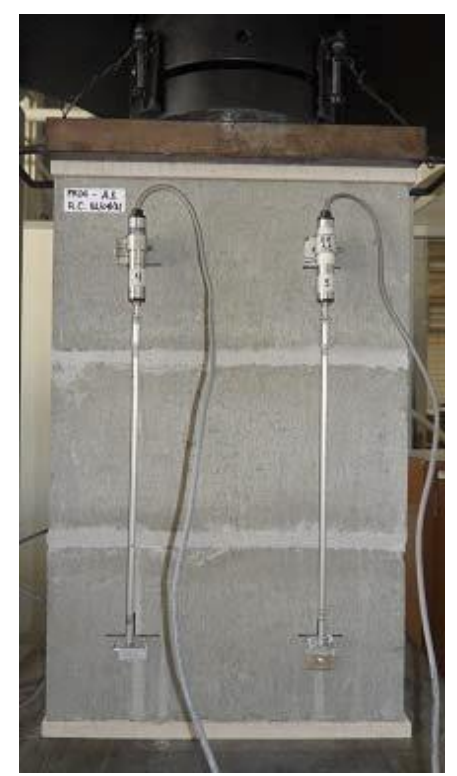

Fonte: Oliveira (2014)

No resultado de tensão-deformação do prisma disponível em Oliveira (2014) observou-se a resistência à compressão média na área bruta de aproximadamente 4,93 $\mathrm{MPa}$, equivalente a 8,99 MPa na área líquida e deformação de pico de 0,72\%o.

Numericamente obteve-se para o prisma de três blocos com argamassamento parcial a deformação de pico de $0,74 \%$ e resistência à compressão na área líquida de 8,63 $\mathrm{MPa}$, correspondendo a erros de 2,78 e 4,00\%, respectivamente. A máxima tensão foi atingida com o deslocamento da placa superior de aproximadamente $0,45 \mathrm{~mm}$. Os diagramas tensãodeformação numérico e experimental estão dispostos na Figura 43. 
Figura 43 - Comparação dos diagramas tensão-deformação dos prismas de três blocos com argamassamento parcial

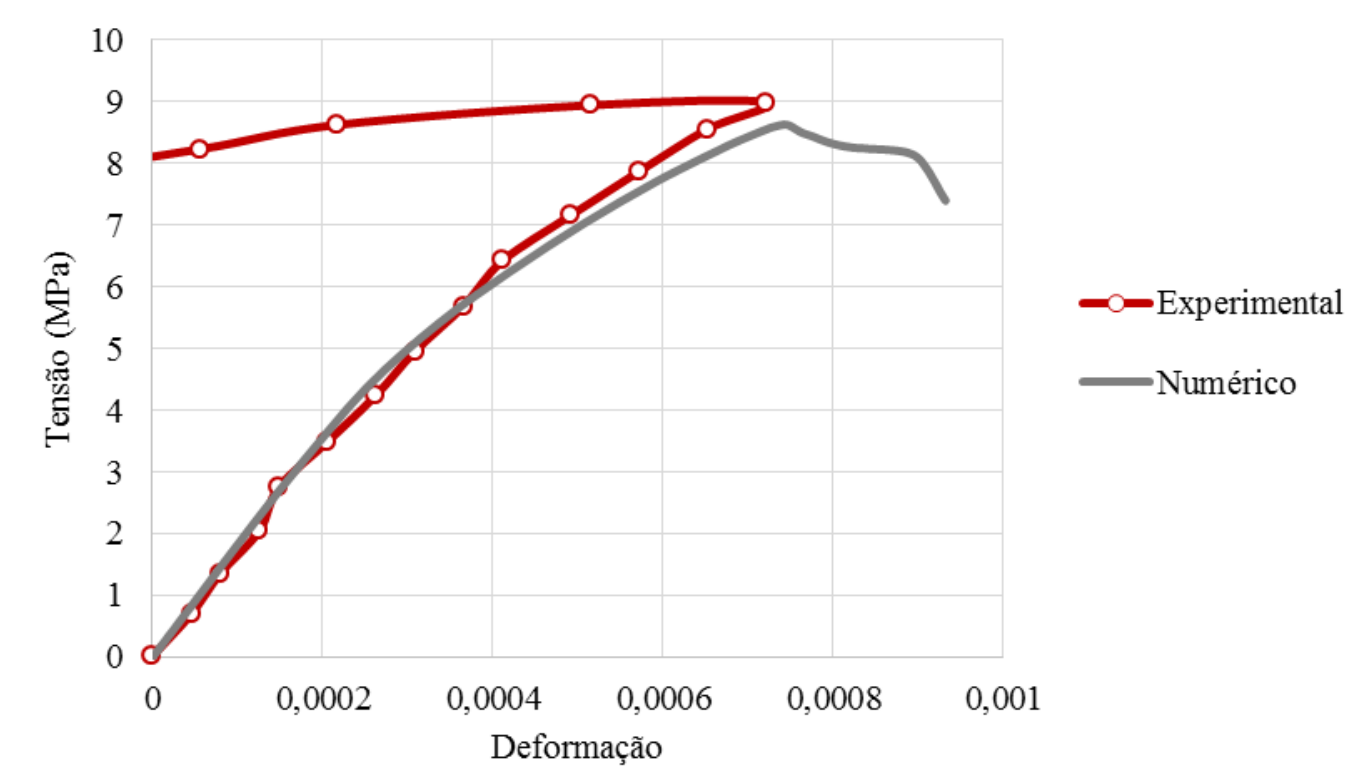

Fonte: Autora (2018)

Na Tabela 13 estão disponíveis alguns valores experimentais e numéricos de tensão na área líquida do prisma de três blocos com argamassamento parcial.

Tabela 13 - Valores de tensão no prisma de três blocos com argamassamento parcial

\begin{tabular}{cccc}
\hline$\varepsilon$ & $\begin{array}{c}\text { Experimental } \\
\sigma(\mathrm{MPa})\end{array}$ & $\begin{array}{c}\text { Numérico } \\
\sigma(\mathrm{MPa})\end{array}$ & $\begin{array}{c}\text { Diferença } \\
(\%)\end{array}$ \\
\hline 0,00013 & 2,05 & 2,01 & 2,20 \\
0,00026 & 4,25 & 4,37 & 2,71 \\
0,00041 & 6,43 & 6,27 & 2,49 \\
0,00057 & 7,87 & 7,71 & 2,02 \\
0,00072 & 8,99 & 8,55 & 4,97 \\
\hline \multicolumn{4}{c}{ Fonte: Autora $(2018)$}
\end{tabular}

Observa-se que a maior diferença ocorreu para o valor final de deformação, assim como se pode notar através da Figura 43, correspondendo a um erro de 4,97\% para a deformação de $0,72 \%$. Para valores de deformação superiores a esse não foi possível a comparação, pois perdeu-se o significado da deformação experimental.

A Figura 44 apresenta a distribuição de tensões principais máximas e mínimas no prisma de três blocos com argamassamento parcial no instante de força máxima de $257,18 \mathrm{kN}$ 
e deslocamento de aproximadamente $0,45 \mathrm{~mm}$ da placa de compressão, bem como um corte em um dos planos de simetria, permitindo a visualização das tensões nas cavidades. 
Figura 44 - Distribuição de tensões principais no prisma de três blocos com argamassamento parcial $(\mathrm{Pa})$

S, Max. Principal (Avg: 75\%)

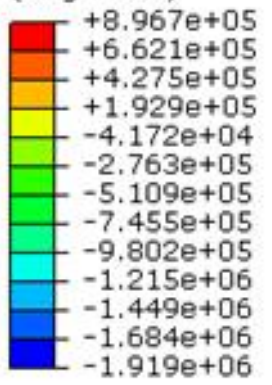

Max: $+8.967 e+05$

Elem: BLOCO-2.3547

Node: 715

Min: $-1.919 e+06$

Elem: ARGAMASSA-1.3 Node: 436
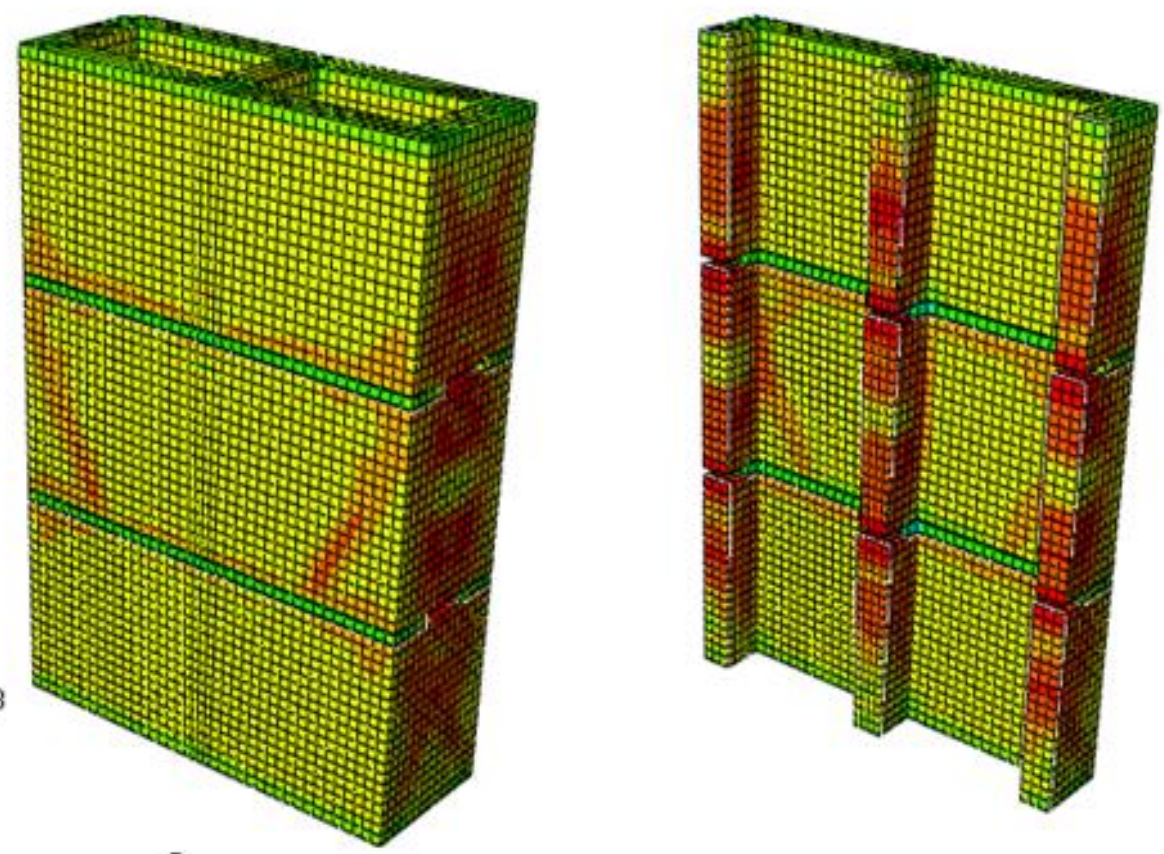

S, Min. Principal (Avg: 75\%)

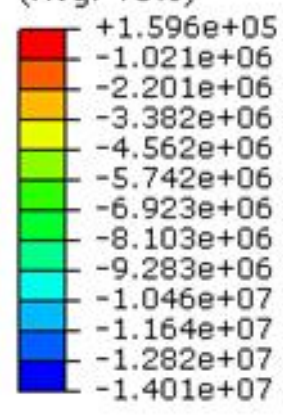

Max: $+1.596 e+05$

Elem: BLOCO-2.3544 Node: 3456

Min: $-1.401 \mathrm{e}+07$

Elem: BLOCO-1.2739

Node: 3007
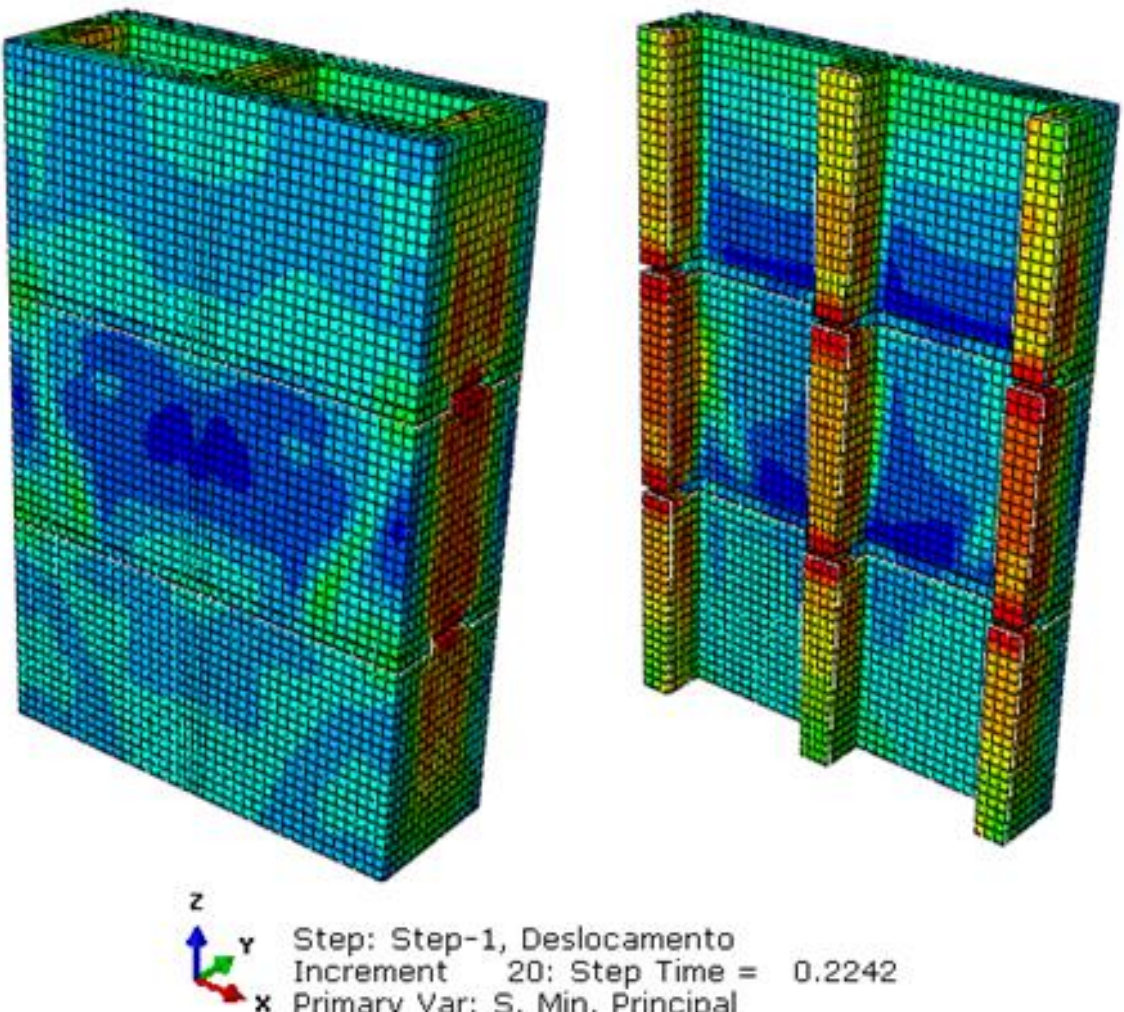

Step: Step-1, Deslocamento

Increment 20: Step Time $=0.2242$

x Primary Var: S, Min. Principal

Fonte: Autora (2018) 
Através da Figura 44 é possível notar que nos septos transversais são desenvolvidas tensões de tração. Nas extremidades dos septos são desenvolvidas tensões de compressão devido ao confinamento imposto pelas placas. Na Figura 45 está apresentado o modo de ruptura do prisma de três blocos com argamassamento parcial obtido experimentalmente por Oliveira (2014).

Figura 45 - Modo de ruptura do prisma de três blocos com argamassamento parcial
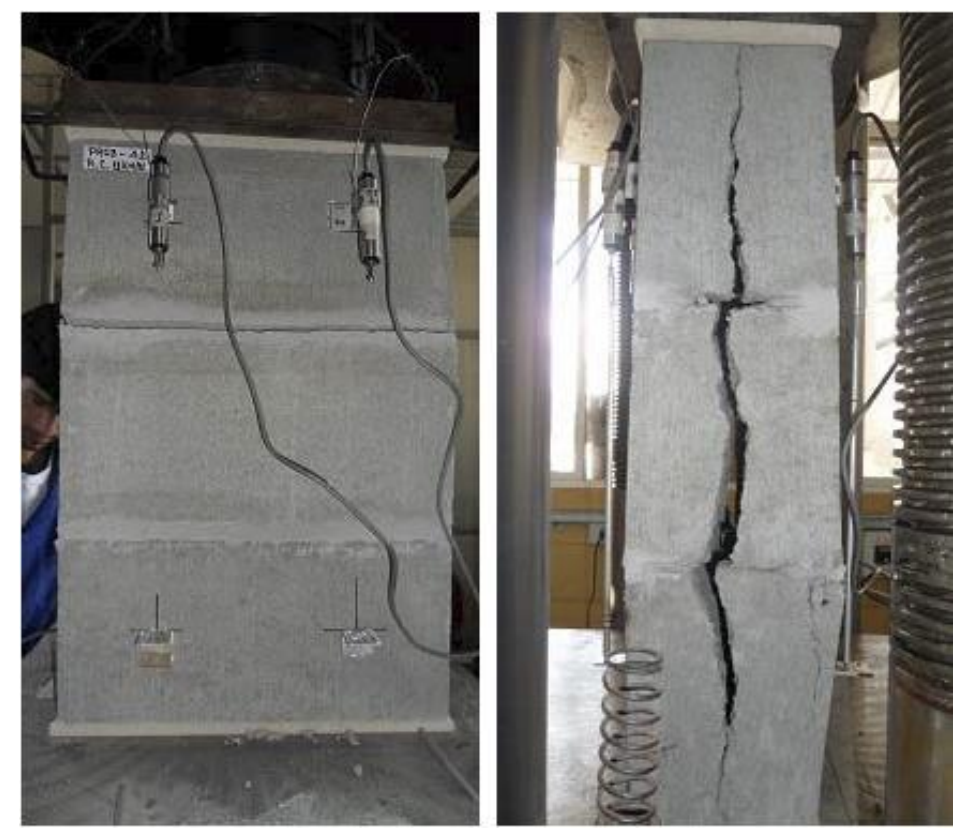

Fonte: Oliveira (2014)

Observa-se que a ruptura ocorre nos septos transversais dos blocos, no mesmo local onde se desenvolveram as tensões principais máximas da modelagem numérica. Assim, consideraram-se validadas as propriedades empregadas na simulação, até o instante de tensão máxima.

Os diagramas tensão-deformação dos quatro prismas modelados com as mesmas propriedades encontram-se na Figura 46. 
Figura 46 - Diagramas tensão-deformação numéricos dos prismas constituídos por blocos de concreto

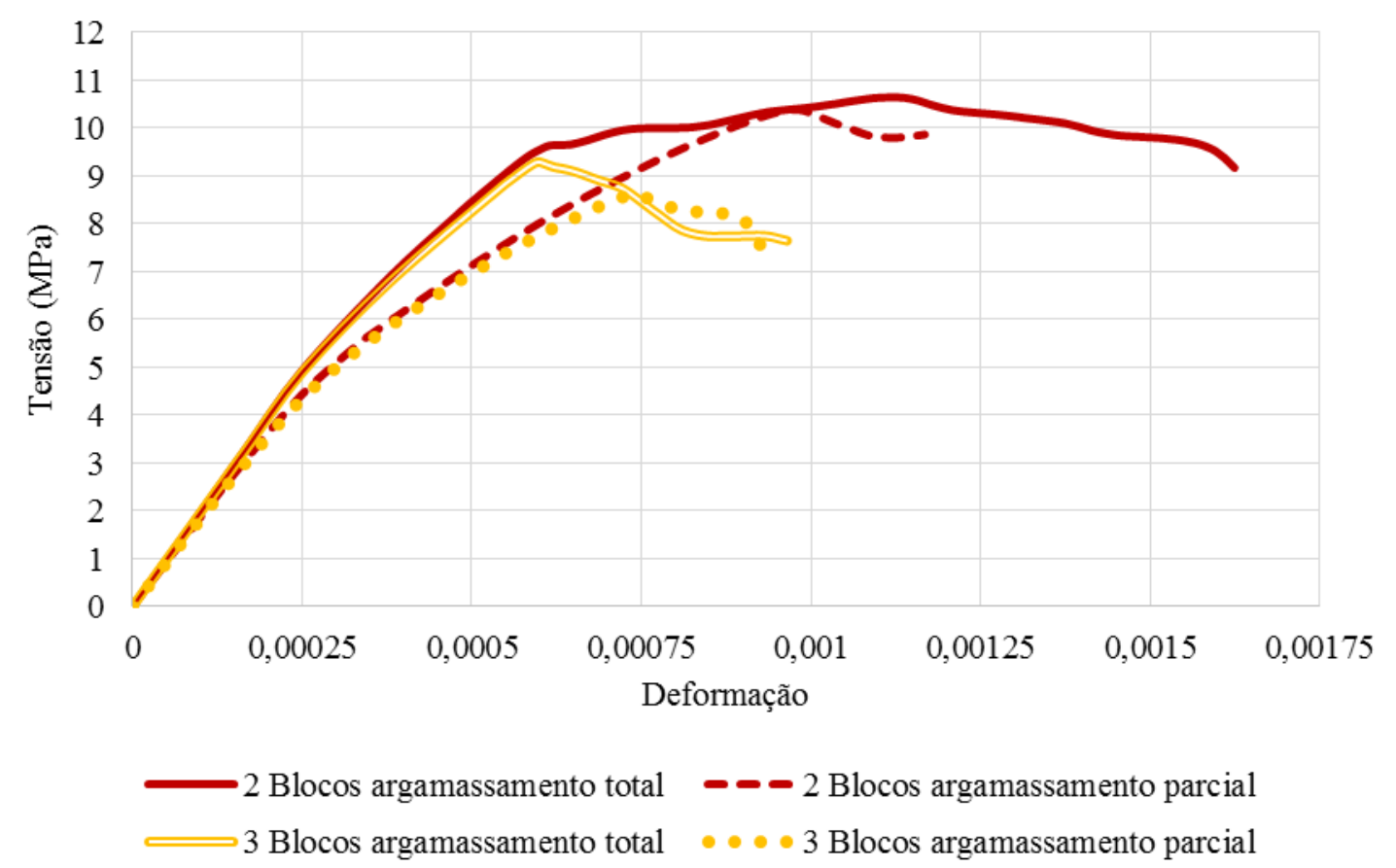

Fonte: Autora (2018)

Nota-se que os prismas de dois blocos possuem resistência maior que aqueles de três blocos, o que é justificado pela adição de uma junta de argamassa que tende a reduzir a resistência dos prismas. Além disso, o efeito do confinamento é mais significante nos prismas de dois blocos, pois, no caso de três blocos a altura dos prismas é maior, ficando o bloco central mais distante das extremidades e, praticamente, sem influência do confinamento.

Constata-se também, através da Figura 46, que os prismas com argamassamento parcial tiveram resistência à compressão inferior àqueles que possuem argamassamento total. O que se justifica pelo fato de no segundo caso existir uma maior área de argamassa, sendo então uma maior área de apoio para o bloco, diminuindo a concentração de tensões no bloco. Além disso, nos prismas com argamassamento parcial tem-se uma indução de tensões de tração nos septos transversais dos blocos.

Para o prisma de três blocos com argamassamento total, a ruptura ocorreu com o deslocamento da placa superior de $0,36 \mathrm{~mm}$. A distribuição de tensões principais máximas e mínimas deste prisma é apresentada na Figura 47. 
Figura 47 - Distribuição de tensões principais no prisma de três blocos com argamassamento total $(\mathrm{Pa})$

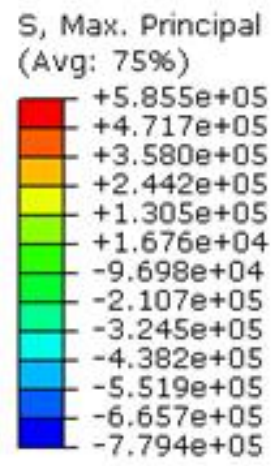

Max: $+5.855 e+05$

Elem: BLOCO-3.3867

Node: 3564

Min: $-7.794 \mathrm{e}+05$

Elem: ARGAMASSA-1.214 Node: 719

5, Min. Principal (Avg: 75\%)

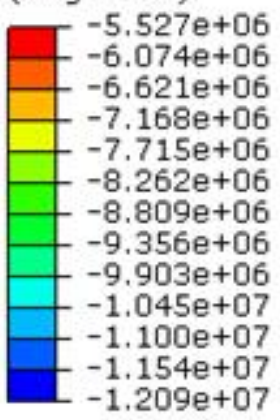

Max: $-5.527 e+06$

Elem: BLOCO-3.3867 Node: 3564

Min: $-1.209 e+07$

Elem: BLOCO-1.3133

Node: 40
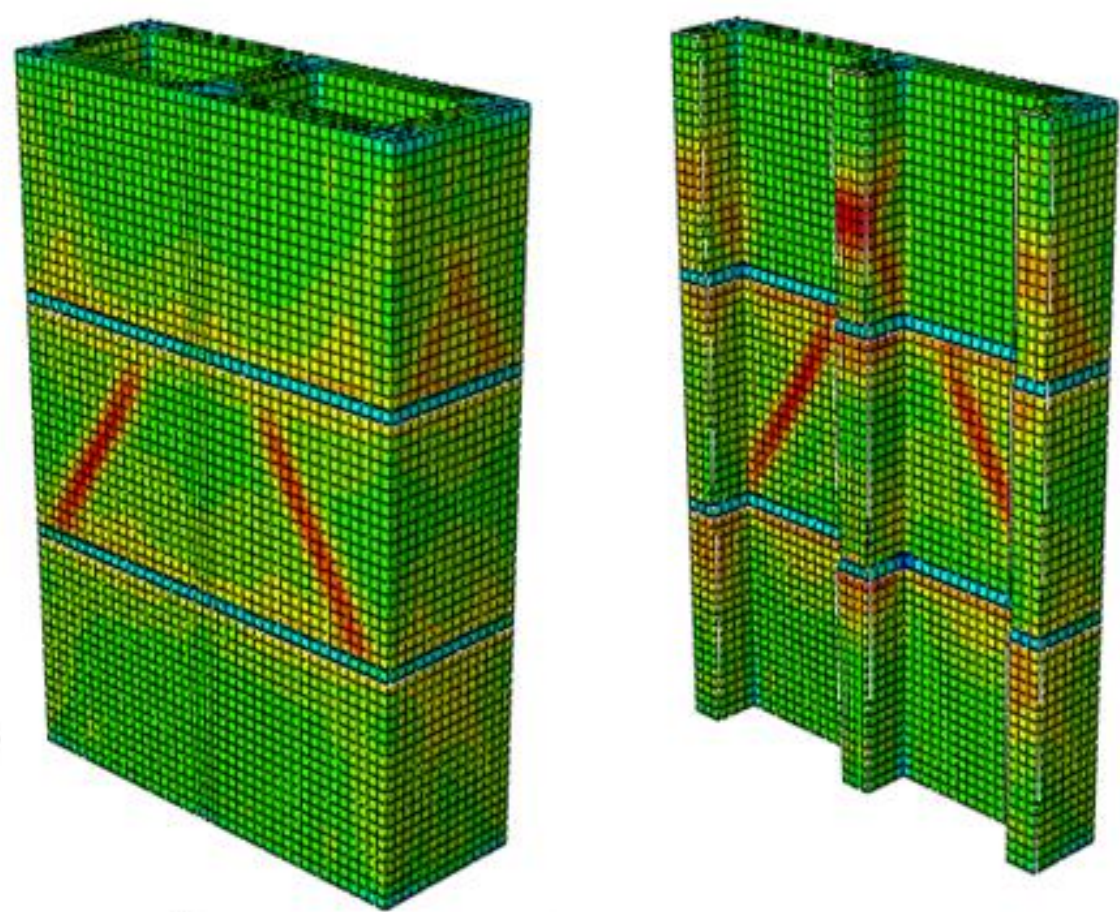

$z \quad$ Step: Step-1, Deslocamento

L ${ }^{\gamma}$ Increment 19: Step Time $=0.1812$

Primary Var: S, Max. Principal
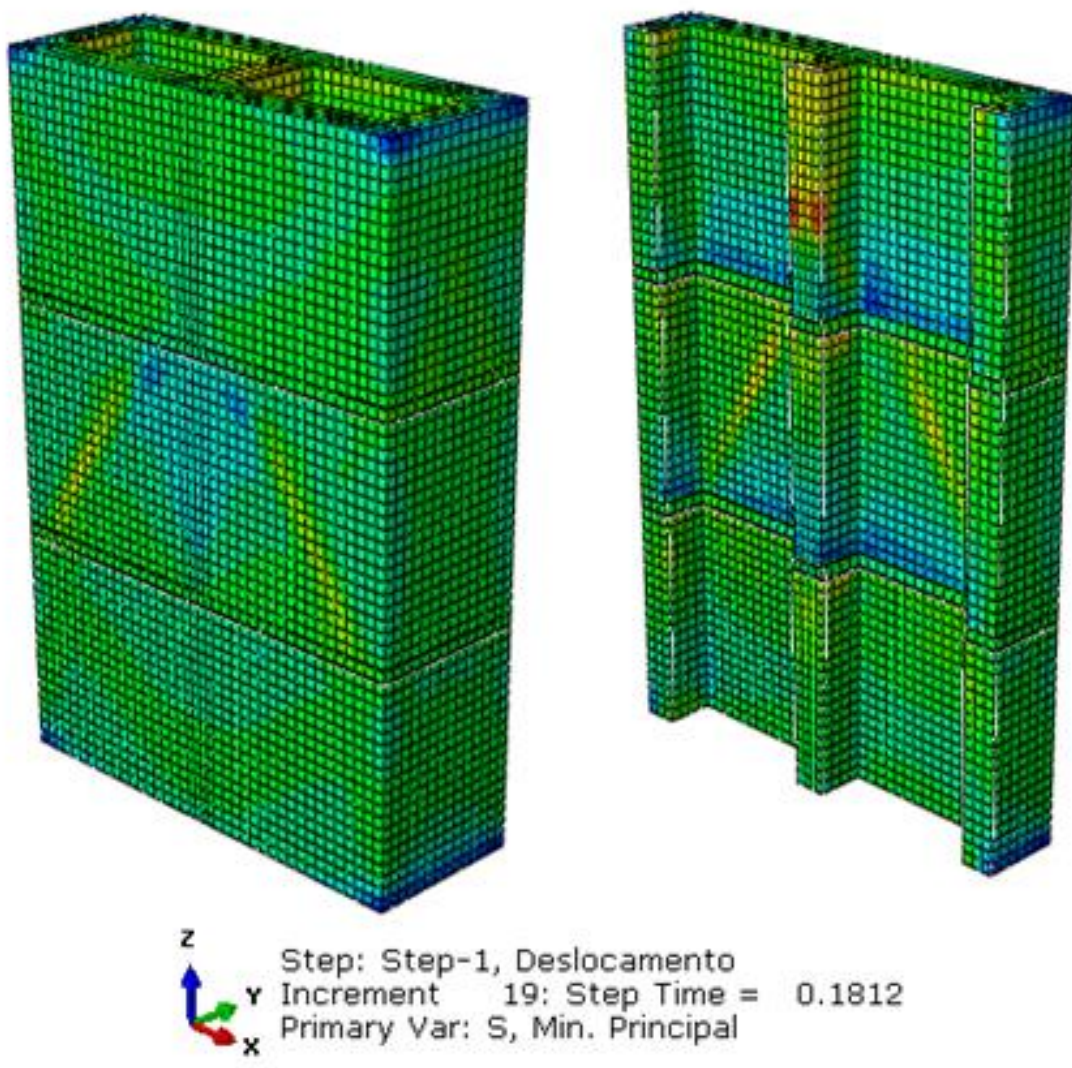

Fonte: Autora (2018) 
Na Figura 48 está ilustrada a distribuição de tensões principais máximas e mínimas do prisma de dois blocos com argamassamento parcial, no instante de força máxima correspondente ao deslocamento da placa de compressão de $0,39 \mathrm{~mm}$.

Figura 48 - Distribuição de tensões principais no prisma de dois blocos com argamassamento parcial $(\mathrm{Pa})$

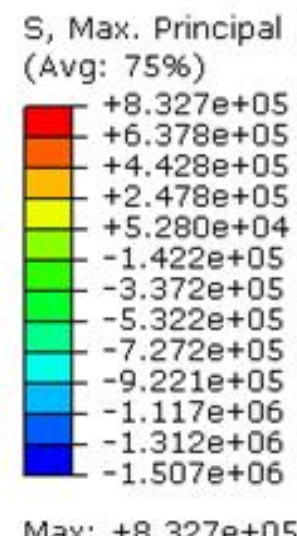

Max: $+8.327 e+05$

Elem: BLOCO-2.3676 Node: 7017

Min: $-1.507 e+06$

Elem: BLOCO-1.3138

Node: 354

S, Min. Principal (Avg: 75\%)

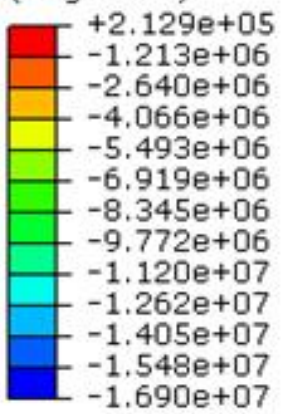

Max: +2.129e+05

Elem: BLOCO-2.4083

Node: 3610

Min: $-1.690 \mathrm{e}+07$

Elem: BLOCO-2.1024

Node: 15
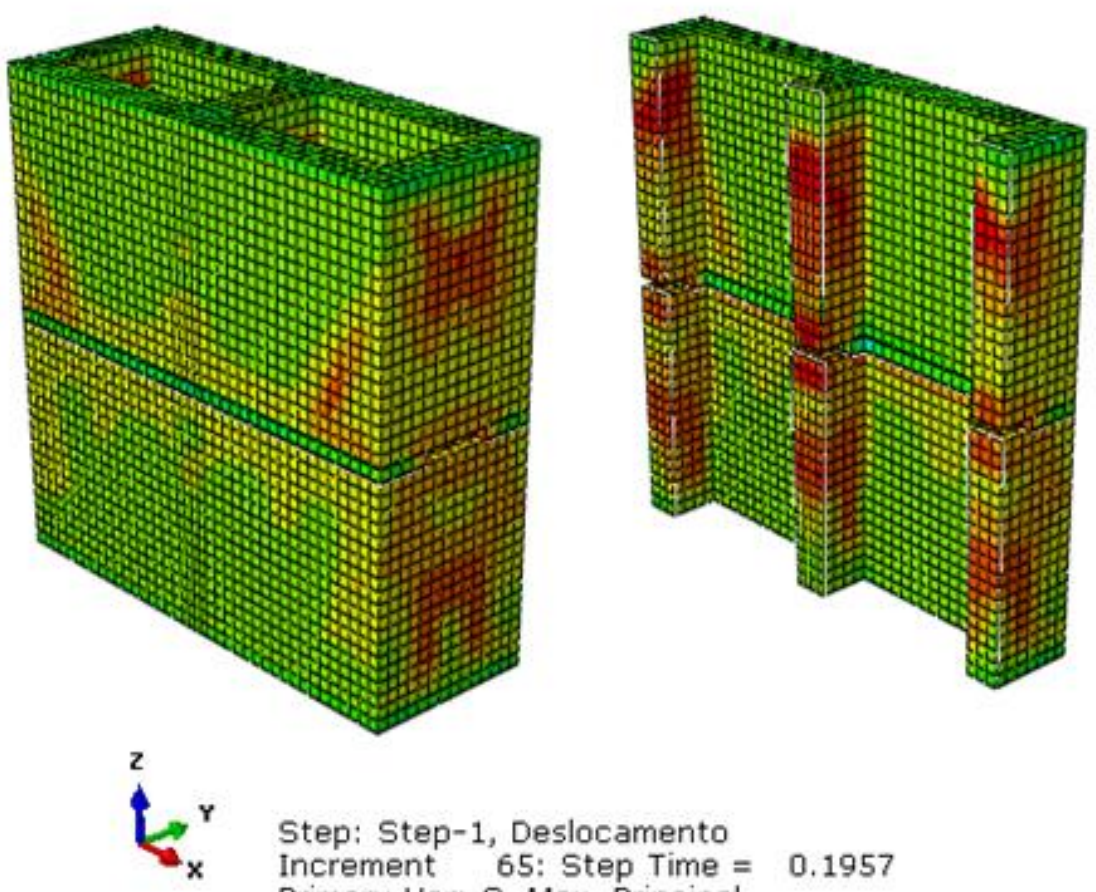

Step: Step-1, Deslocamento

Increment $65:$ Step Time $=0.1957$

Primary Var: S, Max. Principal
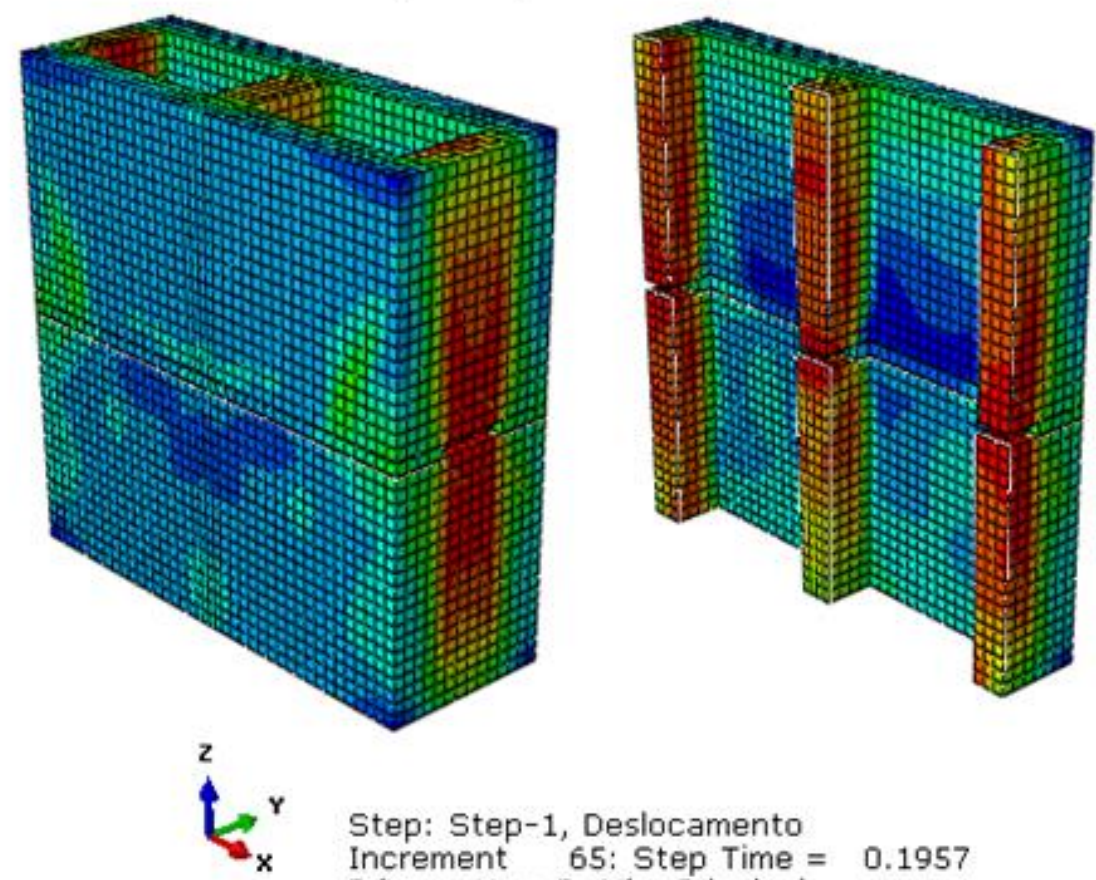

Step: Step-1, Deslocamento

Increment $65:$ Step Time $=0.1957$

Primary Var: $S$, Min. Principal

Fonte: Autora (2018) 
A distribuição de tensões principais máximas e mínimas do prisma de dois blocos com argamassamento total é apresentada na Figura 49, correspondente ao deslocamento da placa superior de $0,45 \mathrm{~mm}$.

Figura 49 - Distribuição de tensões principais no prisma de dois blocos com argamassamento total $(\mathrm{Pa})$

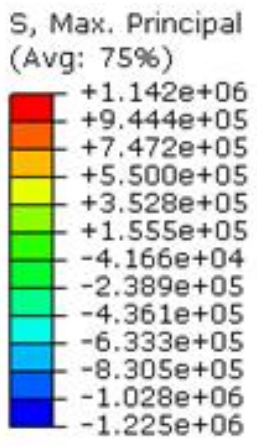

Max: $+1.142 e+06$

Elem: ARGAMASSA-1.66 Node: 29

Min: $-1.225 \mathrm{e}+06$

Elem: BLOCO-1.2760

Node: 6574
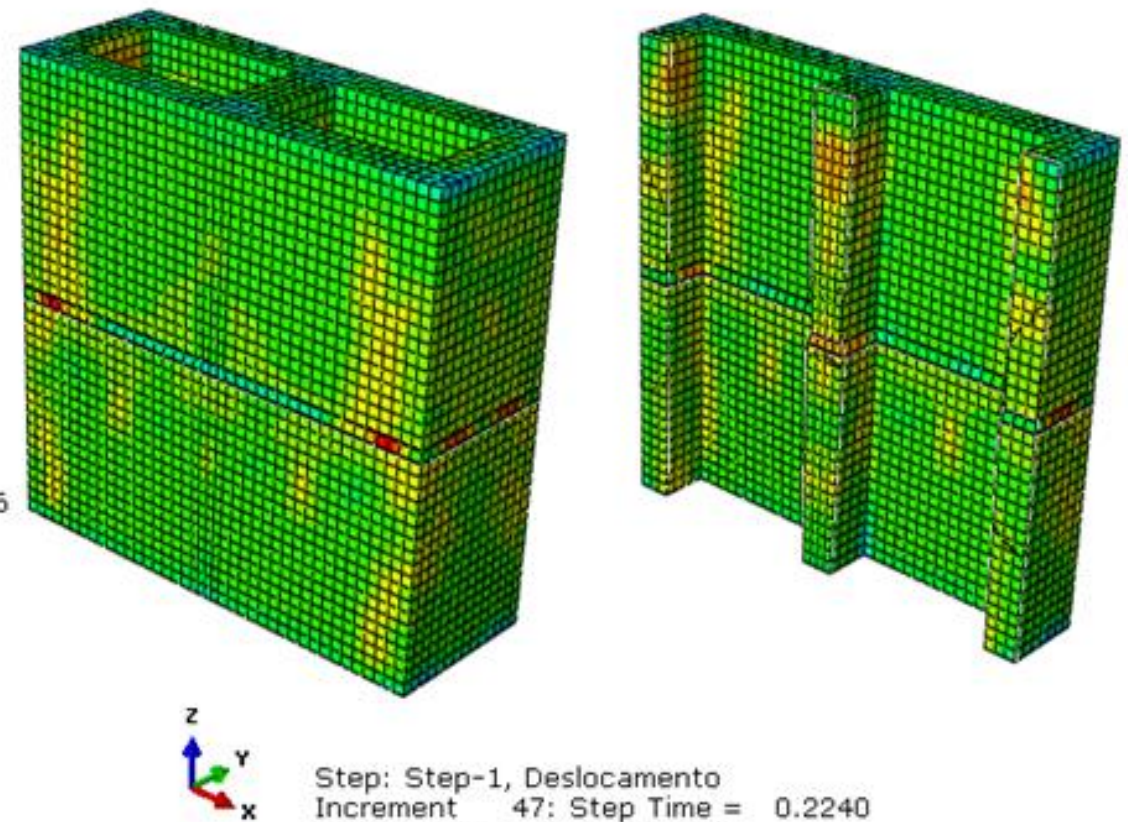

Step: Step-1, Deslocamento

Increment 47: Step Time $=0.2240$

Primary Var: S, Max. Principal

S, Min. Principal (Avg: 75\%)

$+2.904 \mathrm{e}+05$

$-1.239 \mathrm{e}+06$

$-2.768 \mathrm{e}+06$

$-4.298 \mathrm{e}+06$

$-5.827 e+06$

$-7.357 \mathrm{e}+06$

$-8.886 e+06$

$-1.042 e+07$

$-1.194 \mathrm{e}+07$

$-1.347 e+07$

$-1.500 e+07$

$-1.653 e+07$

$-1.806 e+07$

Max: $+2.904 \mathrm{e}+05$

Elem: BLOCO-1.3723

Node: 584

Min: $-1.806 e+07$

Elem: BLOCO-2.1021

Node: 200
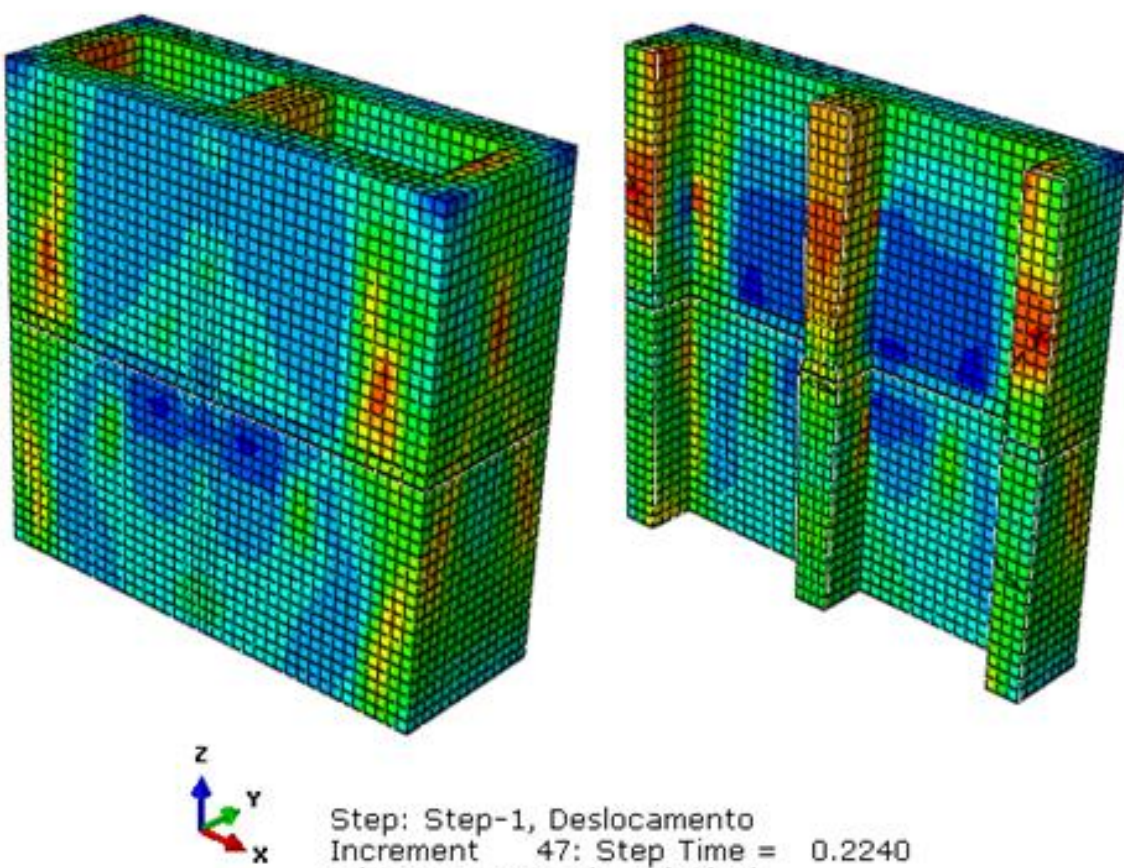

Step: Step-1, Deslocamento

Increment $47:$ Step Time $=0.2240$

Primary Var: S, Min. Principal

Fonte: Autora (2018) 
Observa-se que o tipo de argamassamento e a quantidade de blocos exercem influência no modo de ruptura dos prismas. A Figura 50 ilustra o modo de ruptura do prisma de dois blocos com argamassamento total obtido experimentalmente por Izquierdo (2015).

Figura 50 - Modo de ruptura do prisma de dois blocos com argamassamento total
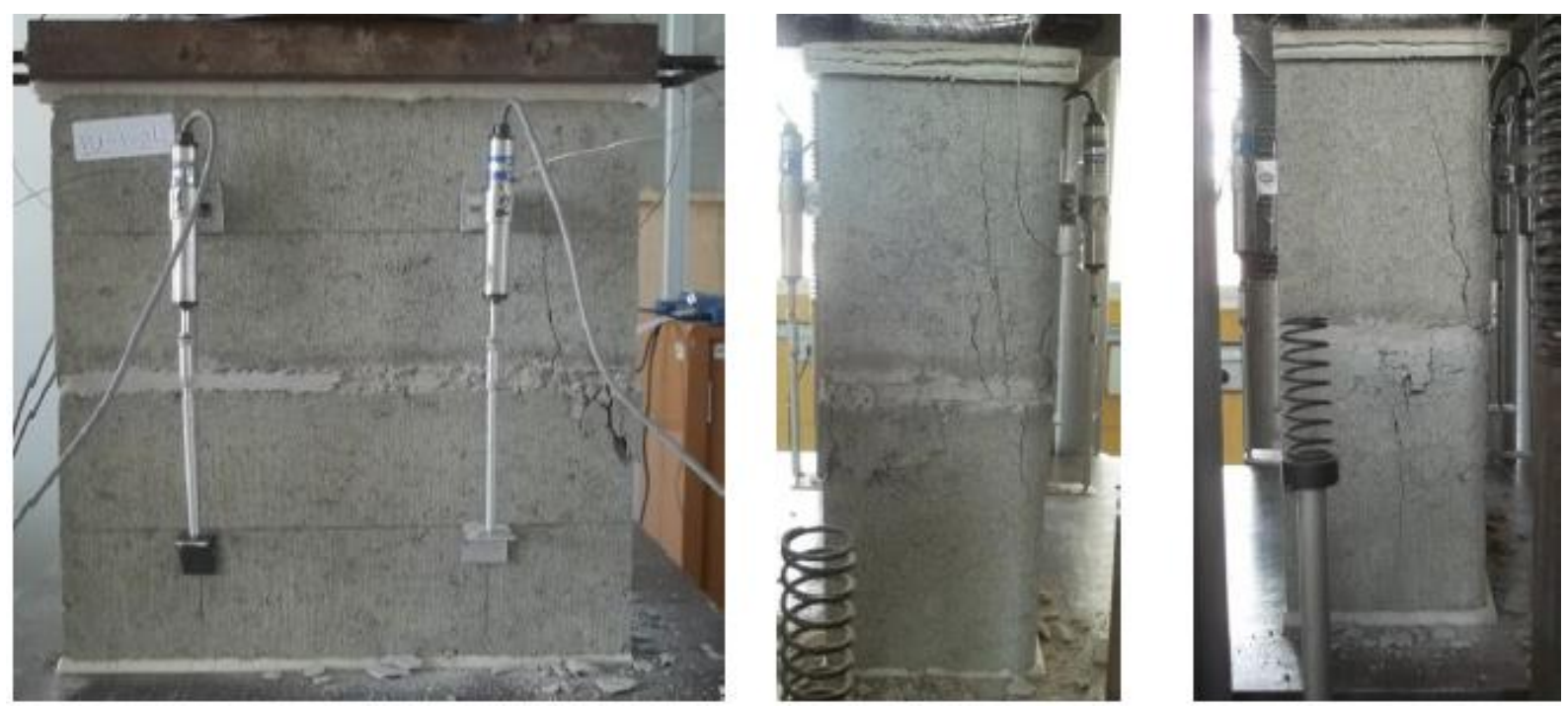

Fonte: Izquierdo (2015)

A primeira imagem mostra uma fissura à direita da face frontal do prisma, mesmo local onde ocorrem as tensões máximas observadas na Figura 49, se iniciando na argamassa (em vermelho) e se estendendo aos blocos (em amarelo). As duas imagens seguintes da Figura 50 mostram fissuras nos septos transversais do prisma. Nesses locais também podem ser observadas tensões máximas, conforme a Figura 49. Assim, considera-se que o modo de ruptura numérico foi similar ao experimental.

$\mathrm{Na}$ Tabela 14 consta uma comparação dos resultados de resistência à compressão obtidos numericamente para os diferentes tipos de prisma. 
Tabela 14 - Resistência à compressão dos diferentes prismas

\begin{tabular}{ccccc}
\hline Prisma & $\begin{array}{c}\text { Força máxima } \\
(\mathrm{kN})\end{array}$ & $\begin{array}{c}\text { Tensão média } \\
\text { máxima }(\mathrm{MPa})\end{array}$ & $\varepsilon$ & $\frac{f_{p}}{f_{b}}$ \\
\hline $\begin{array}{c}3 \text { blocos } \\
\text { argamassamento parcial } \\
3 \text { blocos }\end{array}$ & 257,18 & 8,63 & 0,00074 & 0,46 \\
$\begin{array}{c}\text { argamassamento total } \\
2 \text { blocos }\end{array}$ & 276,85 & 9,29 & 0,0006 & 0,50 \\
$\begin{array}{c}\text { argamassamento parcial } \\
2 \text { blocos }\end{array}$ & 309,44 & 10,39 & 0,00097 & 0,56 \\
argamassamento total & 317,15 & 10,65 & 0,00112 & 0,57 \\
\hline
\end{tabular}

Fonte: Autora (2018)

Observa-se que as eficiências prisma-bloco para todos os prismas, exceto o primeiro, ficaram dentro do limite estabelecido na Tabela 3, sendo que o primeiro foi comparado com resultados experimentais. Assim, considerou-se que os resultados de compressão em temperatura ambiente dos prismas estavam adequados, então, deu-se sequência ao trabalho com o prisma de dois blocos e argamassamento total. 


\section{SIMULAÇÕES TÉRMICAS}

\subsection{SIMULAÇÕES TÉRMICAS DA ALVENARIA COMPOSTA POR BLOCOS CERÂMICOS}

Os experimentos realizados por Rosemann (2011) serviram de base para as simulações da alvenaria composta por blocos cerâmicos em situação de incêndio. O campo térmico desenvolvido nas paredes foi representado por meio de um bloco, pois o fluxo de calor medido experimentalmente ocorreu na direção transversal. Não foram representadas as juntas de argamassa.

As dimensões dos pequenos vazados foram estimadas conforme o percentual total de vazios, de 52\%, e com as dimensões das grandes cavidades disponíveis em Rosemann (2011). A geometria, as dimensões do bloco cerâmico e do revestimento utilizados nas simulações estão dispostas na Figura 51.

Figura 51 - Geometria e dimensões do bloco cerâmico e do revestimento (mm)

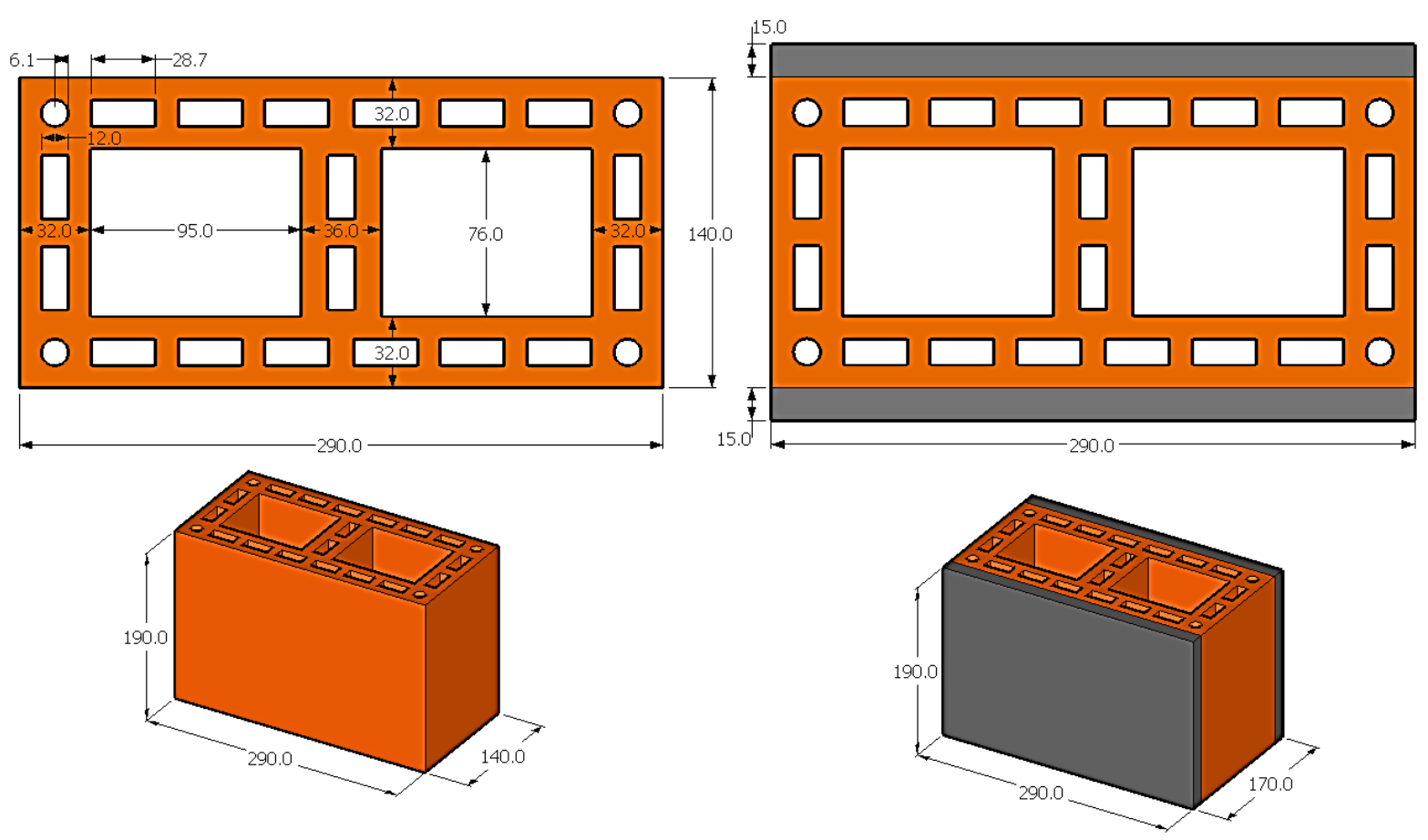

Fonte: Autora (2018) 
Utilizaram-se 15750 elementos para o bloco e 5820 para os revestimentos em argamassa, sendo todos tridimensionais do tipo DC3D8, elementos de oito nós da família “transferência de calor", com dimensões aproximadas de $3 \mathrm{~mm}$ na seção transversal e $30 \mathrm{~mm}$ na altura. A malha da seção transversal do bloco foi refinada observando-se a tendência da temperatura medida no instante final da simulação de incêndio, na face não exposta ao fogo, chegando à configuração ilustrada na Figura 52.

Figura 52 - Malhas utilizadas nas modelagens cerâmicas
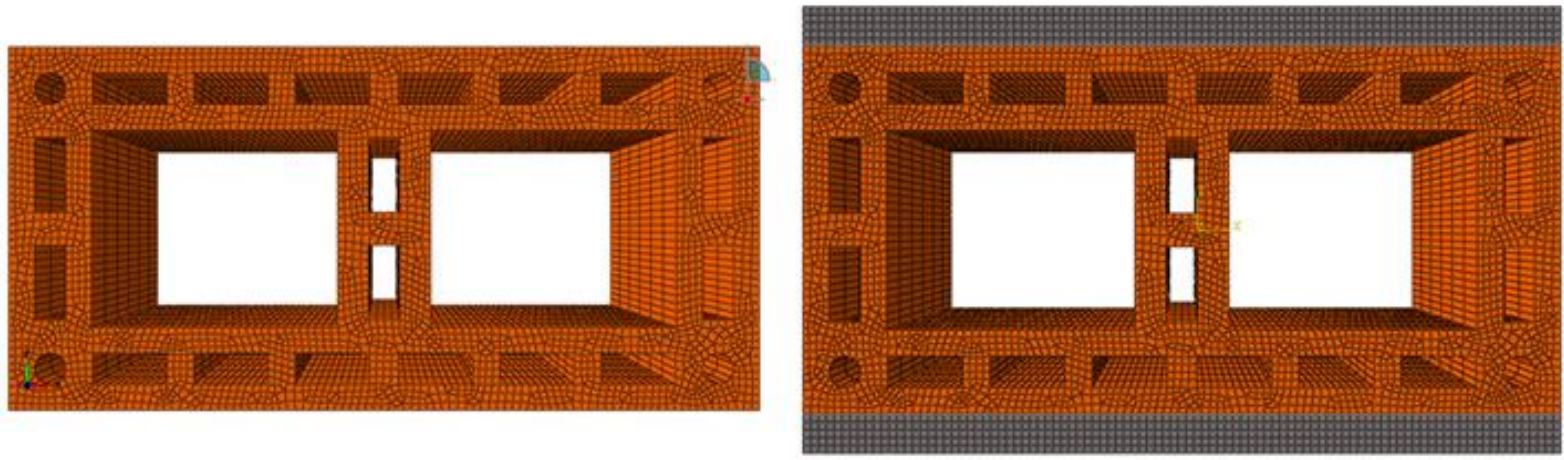

Fonte: Autora (2018)

As propriedades térmicas do bloco cerâmico foram inicialmente ajustadas e em seguida adicionou-se o revestimento em argamassa. Nos experimentos realizados por Rosemann (2011), a temperatura ambiente era de $21,1^{\circ} \mathrm{C}$ para a parede sem revestimento e $22^{\circ} \mathrm{C}$ para a parede com revestimento. Essas temperaturas foram aplicadas por meio de um passo inicial nas simulações, e durante a etapa de incêndio considerou-se que as faces não expostas ao fogo perdiam calor para o ambiente por meio de radiação e convecção. $O$ valor de emissividade empregado em ambas as faces foi de 0,95 .

Aplicou-se na face exposta ao fogo elevação de temperatura conforme a curva padrão ISO 834-1:1999, onde considerou-se transferência de calor por meio de radiação e convecção com coeficiente de $25 \mathrm{~W} /\left(\mathrm{m}^{2} . \mathrm{K}\right)$. Na face exposta ao ambiente empregou-se o coeficiente de convecção de $4 \mathrm{~W} /\left(\mathrm{m}^{2} . \mathrm{K}\right)$. Nas cavidades não foram representadas a radiação e a convecção. Então a condutividade térmica da cerâmica foi ligeiramente aumentada. A Figura 53 apresenta o esquema das simulações. 
Figura 53 - Esquema das modelagens térmicas das paredes cerâmicas

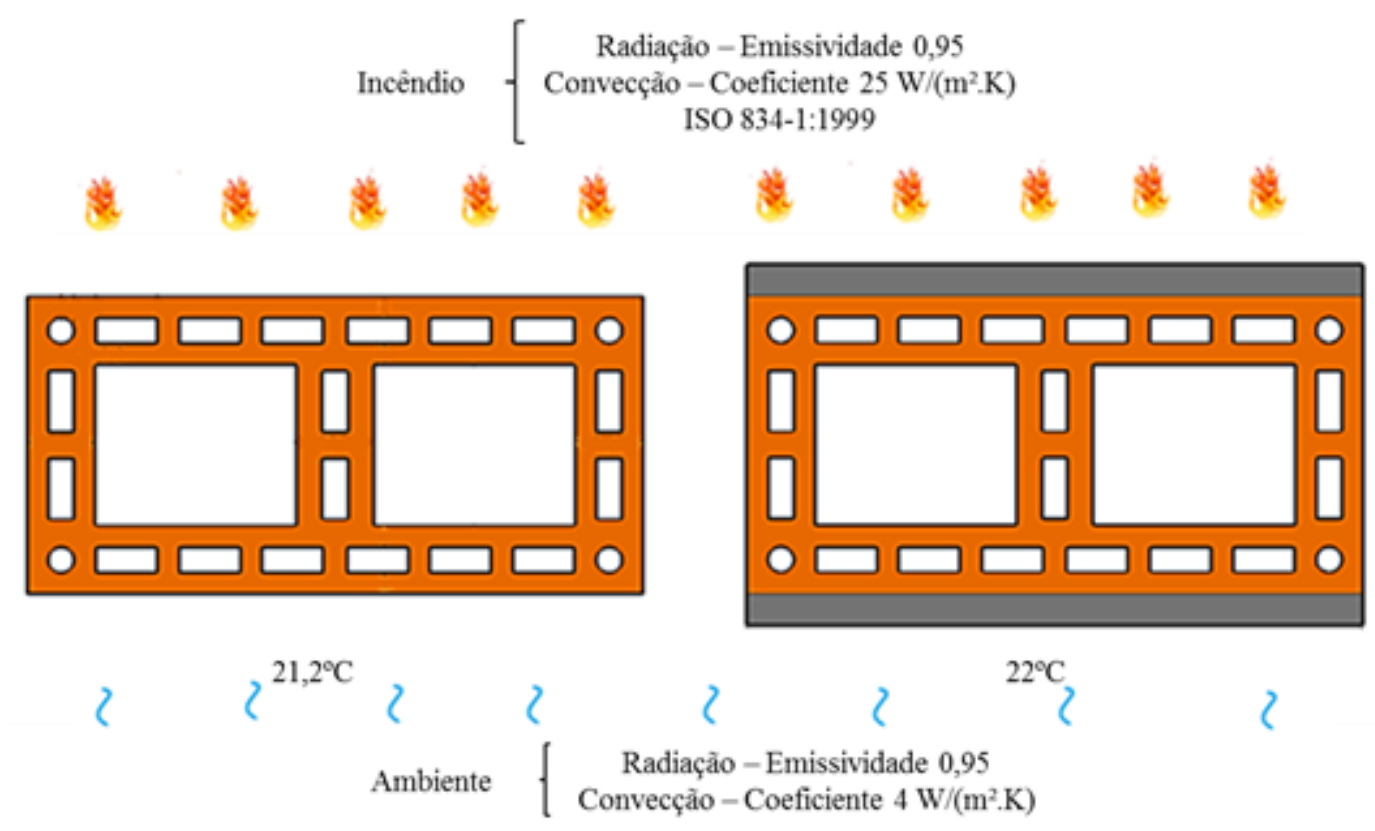

Fonte: Autora (2018)

Os valores de massa específica e calor específico do bloco cerâmico e argamassa utilizados nas simulações foram os propostos em Rosemann (2011). Já a condutividade térmica foi variada até que se obtivesse um bom ajuste entre as curvas experimentais e numéricas de elevação de temperatura das faces não expostas ao fogo. Na Tabela 15 constam as propriedades térmicas utilizadas nas modelagens aqui desenvolvidas. 
Tabela 15 - Propriedades térmicas da alvenaria cerâmica utilizadas nas simulações

\begin{tabular}{ccccccc}
\hline \multicolumn{3}{c}{ Bloco cerâmico } & \multicolumn{3}{c}{ Argamassa } \\
Temp. & $\begin{array}{c}\text { Massa } \\
\text { específica }\end{array}$ & $\begin{array}{c}\text { Calor } \\
\text { específico }\end{array}$ & Condutividade & $\begin{array}{c}\text { Massa } \\
\text { específica }\end{array}$ & $\begin{array}{c}\text { Calor } \\
\text { específico }\end{array}$ & Condutividade \\
${ }^{\circ} \mathrm{C}$ & $\mathrm{kg} / \mathrm{m}^{3}$ & $\mathrm{~J} /(\mathrm{kg} . \mathrm{K})$ & $\mathrm{W} /(\mathrm{m} . \mathrm{K})$ & $\mathrm{kg} / \mathrm{m}^{3}$ & $\mathrm{~J} /(\mathrm{kg} . \mathrm{K})$ & $\mathrm{W} /(\mathrm{m} . \mathrm{K})$ \\
\hline 20 & 1750 & 700 & 1,5 & 2100 & 800 & 2,1 \\
50 & 1750 & 700 & 1,5 & 2100 & 800 & 2,0 \\
70 & 1750 & 700 & 1,5 & 2100 & 800 & 2,0 \\
85 & 1750 & 700 & 1,5 & 2100 & 800 & 1,0 \\
99 & 1750 & 1400 & 1,5 & 2100 & 2400 & 0,9 \\
101 & 1750 & 700 & 1,5 & 2100 & 1200 & 0,9 \\
200 & 1750 & 700 & 1,5 & 2100 & 800 & 0,9 \\
300 & 1750 & 700 & 1,5 & 2100 & 800 & 0,9 \\
400 & 1750 & 700 & 1,5 & 2100 & 800 & 0,9 \\
500 & 1750 & 700 & 2,3 & 2100 & 800 & 0,9 \\
1000 & 1750 & 700 & 2,3 & 2100 & 800 & 0,9 \\
1500 & 1750 & 700 & 2,3 & 2100 & 800 & 0,9 \\
\hline \multicolumn{7}{r}{} \\
\hline 5
\end{tabular}

Observa-se que próximo de $100^{\circ} \mathrm{C}$ ocorre um pico no valor de calor específico do bloco cerâmico, assim como sugere o Eurocode 6 Parte 1-2:2005, devido ao calor latente de vaporização da umidade presente no material. Conforme citado no tópico sobre a radiação, essa se torna o principal mecanismo de transferência de calor em temperaturas acima de $400^{\circ} \mathrm{C}$. Isso justifica a elevação da condutividade térmica da cerâmica, já que a radiação não foi representada nas cavidades do bloco. Os valores de condutividade térmica da argamassa ficaram próximos aos propostos por Stancato (2000).

\subsubsection{Resultados e comparações}

Foi verificada a elevação de temperatura na face não exposta das modelagens em pontos projetados no centro das maiores cavidades. Na modelagem sem revestimento as temperaturas nesses pontos foram ligeiramente inferiores às encontradas no ponto central. Isso se deu pelo fato de não representar a convecção e a radiação nas cavidades, além do ponto central estar em local de maior concentração de material cerâmico, facilitando a condução. 
$\mathrm{Na}$ modelagem com revestimento, a diferença de temperatura desses pontos relacionados ao central foi menor. Isso ocorreu porque a camada de argamassa permitiu uma melhor uniformização da temperatura na face não exposta ao fogo por meio da condução.

Rosemann (2011) realizou a leitura de temperatura em cinco pontos nas faces não expostas ao fogo e então calculou a média. A validação das modelagens foi feita comparandose a elevação de temperatura em um ponto central nas faces não expostas ao fogo com os resultados médios experimentais. Na Figura 54 constam os resultados de elevação de temperatura numérico e experimental nas faces não expostas ao fogo.

Figura 54 - Elevação de temperatura nas faces não expostas ao fogo das paredes cerâmicas

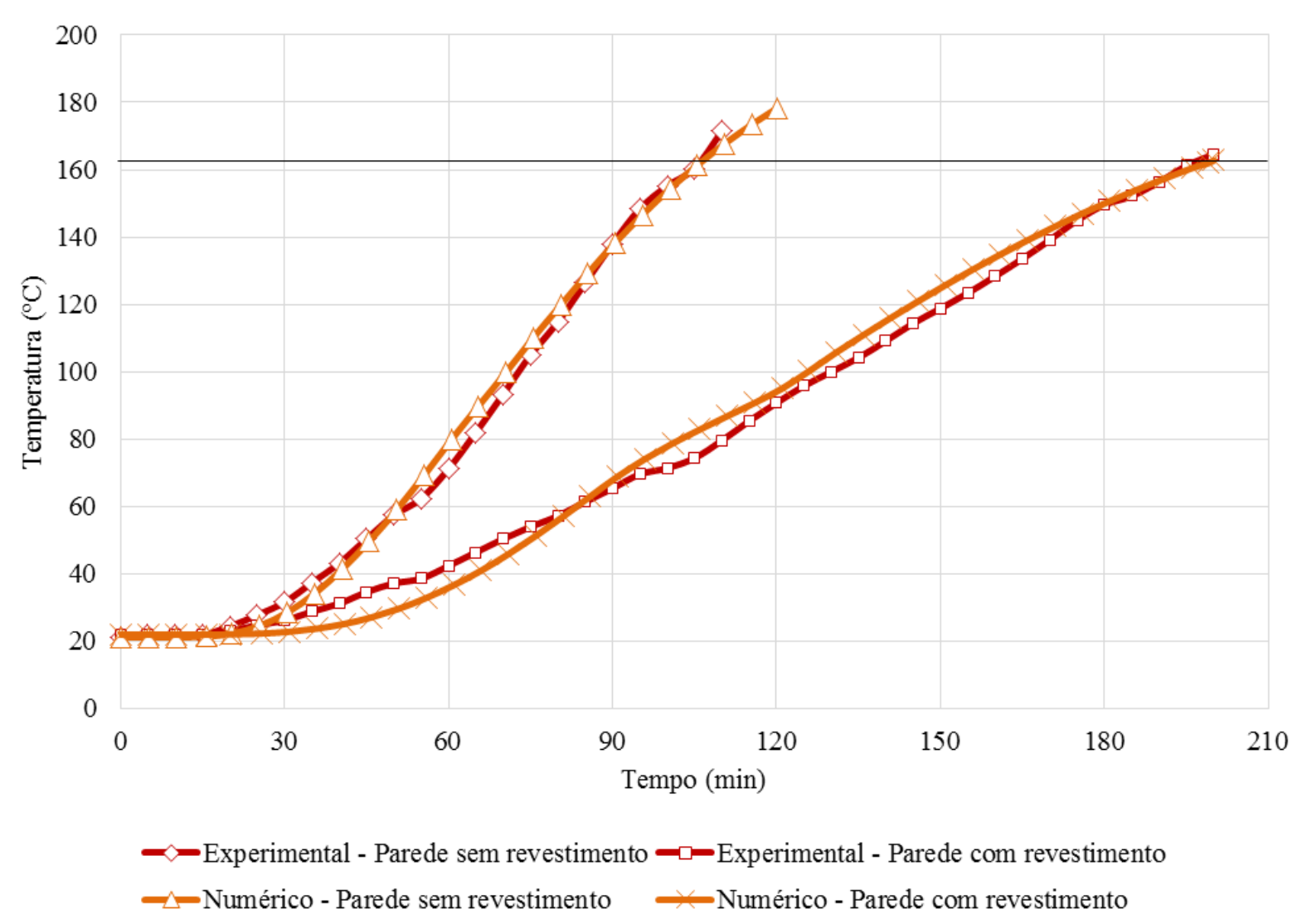

Fonte: Autora (2018)

As temperaturas limites de isolamento térmico, $161,2^{\circ} \mathrm{C}$ e $162,0^{\circ} \mathrm{C}$, das paredes sem revestimento e com revestimento foram alcançadas experimentalmente aos 106 e 196 minutos de ensaio respectivamente. Nas modelagens numéricas obtiveram-se 105 e 199 minutos, correspondente a erros de 0,94 e 1,53\%. Na Tabela 16 estão presentes os resultados obtidos nas faces não expostas em intervalos de 10 minutos. 
Tabela 16 - Medidas de temperatura nas faces não expostas

\begin{tabular}{|c|c|c|c|c|c|c|}
\hline \multirow[b]{2}{*}{$t(\min )$} & \multicolumn{3}{|c|}{ Parede sem revestimento } & \multicolumn{3}{|c|}{ Parede com revestimento } \\
\hline & $\begin{array}{c}\text { Experimental } \\
\mathrm{T}\left({ }^{\circ} \mathrm{C}\right)\end{array}$ & $\begin{array}{c}\text { Numérico } \\
\mathrm{T}\left({ }^{\circ} \mathrm{C}\right)\end{array}$ & $\begin{array}{c}\text { Diferença } \\
(\%)\end{array}$ & $\begin{array}{c}\text { Experimental } \\
\mathrm{T}\left({ }^{\circ} \mathrm{C}\right)\end{array}$ & $\begin{array}{c}\text { Numérico } \\
\mathrm{T}\left({ }^{\circ} \mathrm{C}\right)\end{array}$ & $\begin{array}{c}\text { Diferença } \\
(\%)\end{array}$ \\
\hline 40 & 43,2 & 41,4 & 4,3 & 31,2 & 25,2 & 19,3 \\
\hline 50 & 57,4 & 59,0 & 2,8 & 37,2 & 29,7 & 20,1 \\
\hline 60 & 71,2 & 79,8 & 12,1 & 42,4 & 36,7 & 13,5 \\
\hline 70 & 93,4 & 99,8 & 6,9 & 50,4 & 45,9 & 8,9 \\
\hline 80 & 114,8 & 119,7 & 4,3 & 57,2 & 57,1 & 0,2 \\
\hline 90 & 138 & 138,3 & 0,2 & 65,4 & 69,0 & 5,5 \\
\hline 100 & 155,2 & 154,4 & 0,5 & 71,4 & 78,8 & 10,3 \\
\hline 110 & 171,4 & 167,7 & 2,2 & 79,6 & 86,8 & 9,1 \\
\hline 120 & - & 173,5 & - & 90,8 & 95,0 & 4,6 \\
\hline 130 & - & 178,2 & - & 100 & 105,8 & 5,8 \\
\hline 140 & - & - & - & 109,2 & 116,1 & 6,3 \\
\hline 150 & - & - & - & 118,8 & 125,8 & 5,9 \\
\hline 160 & - & - & - & 128,4 & 134,9 & 5,1 \\
\hline 170 & - & - & - & 139,2 & 143,2 & 2,9 \\
\hline 180 & - & - & - & 149,6 & 150,7 & 0,7 \\
\hline 190 & - & - & - & 156,4 & 157,4 & 0,6 \\
\hline 200 & - & - & - & 164,6 & 162,8 & 1,1 \\
\hline
\end{tabular}

Fonte: Autora (2018)

Observa-se que a maior diferença percentual de temperatura ocorreu aos 50 minutos para a parede com revestimento, correspondente a um erro de 20,1\%. Com o adequado ajuste das curvas e pequenos valores de erros para os tempos onde são atingidas as variações de temperatura limite do critério de isolamento térmico considerou-se que as modelagens foram bem calibradas, possibilitando a utilização das propriedades térmicas da argamassa nas simulações seguintes.

Na Figura 55 estão presentes os campos térmicos obtidos na simulação da parede sem revestimento, em intervalos de 30 minutos e no instante em que se atinge a temperatura limite do isolamento térmico. 
Figura 55 - Campos térmicos desenvolvidos na parede sem revestimento $\left({ }^{\circ} \mathrm{C}\right)$

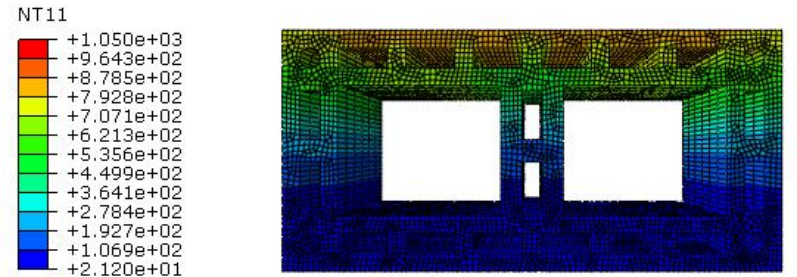

30 minutos

$\stackrel{Y}{\rightarrow}$ Step: Heat transfer

Increment 157: Step Time $=1828$

Deformed Var: not set Deformation Scale Factor: not set

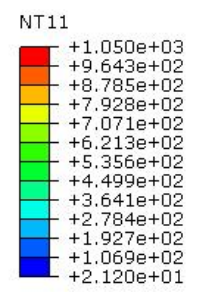

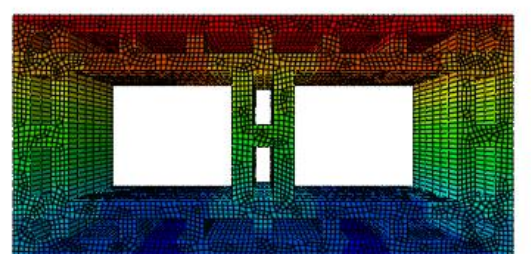

90 minutos

Step: Heat transfer

Increment 193: Step Time $=5428$

Deformed Var: not set Deformation Scale Factor: not set

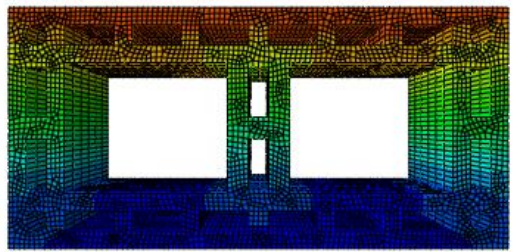

60 minutos

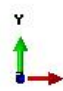

Step: Heat transfer

Increment 175: Step Time $=3628$.

Primary Var: NT11

Deformed Var: not set Deformation Scale Factor: not set

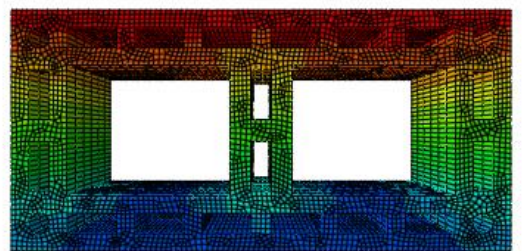

105 minutos

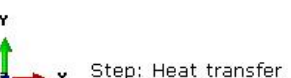

Increment 202: Step Time $=6328$.

Deformed Var: not set Deformation Scale Factor: not set

Fonte: Autora (2018)

$\mathrm{Na}$ Figura 56 são apresentados os campos térmicos desenvolvidos na simulação numérica da parede de bloco cerâmico com revestimento, em intervalos aproximados de 30 minutos e no tempo em que se atinge a temperatura limite do isolamento térmico. 
Figura 56 - Campos térmicos desenvolvidos na parede com revestimento $\left({ }^{\circ} \mathrm{C}\right)$
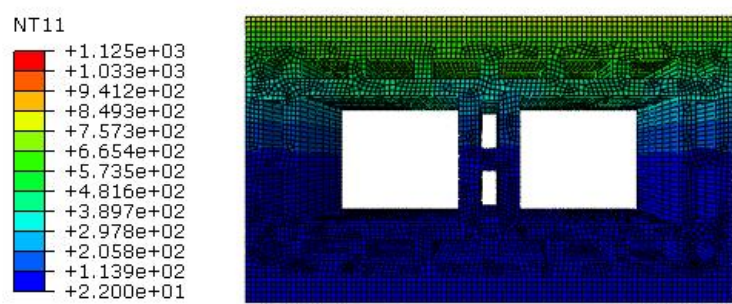

31 minutos

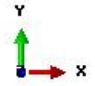

Step: Heat transfer

Step Time $=1858$

Primary Var: NT11

Deformed Var: not set Deformation Scale Factor: not set
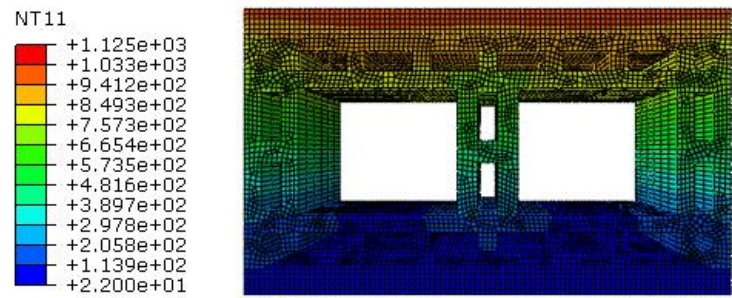

91 minutos
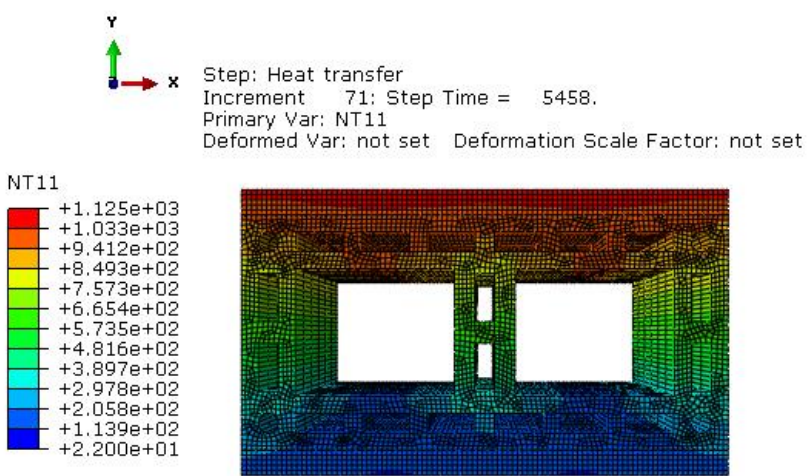

151 minutos

$\underset{\mathrm{Y}}{\mathrm{Y}} \mathrm{x}$ Step: Heat transfer

Increment 107: Step Time $=9058$

Deformed Var: not set Deformation Scale Factor: not set

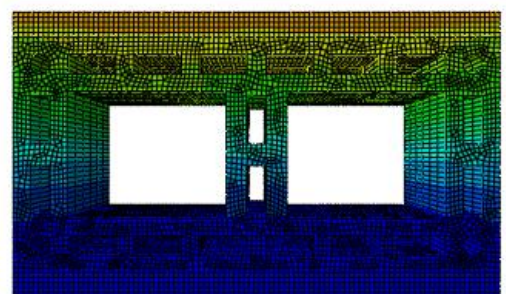

61 minutos

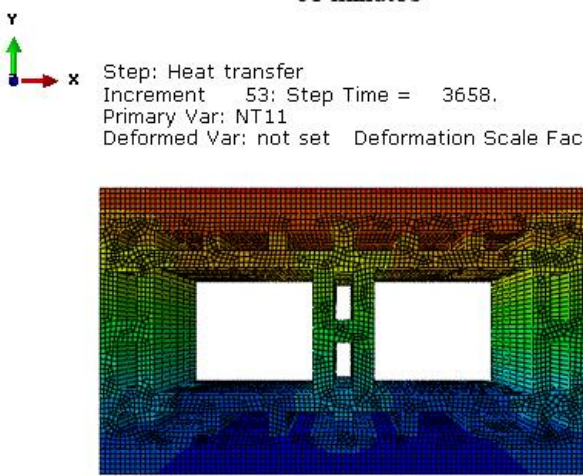

121 minutos
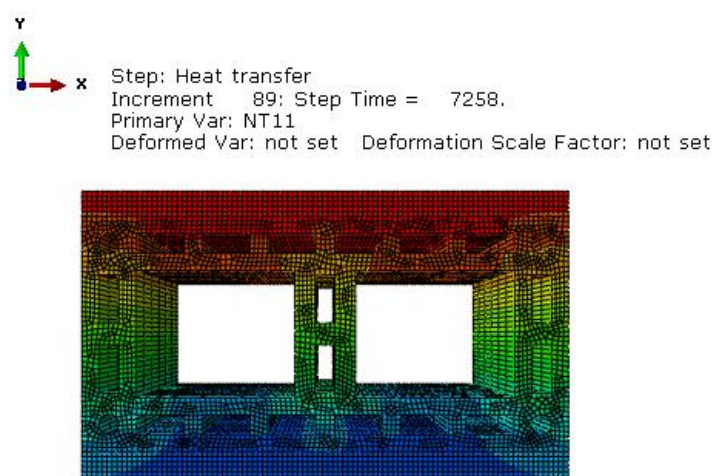

199 minutos

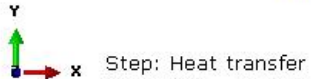

Increment 136: Step Time $=1.1958 \mathrm{E}+04$

Deformed Var: not set Deformation Scale Factor: not set

Fonte: Autora (2018)

\subsection{SIMULAÇÕES TÉRMICAS DOS PRISMAS COMPOSTOS POR BLOCOS DE CONCRETO}

O ensaio de resistência ao fogo fornecido pela empresa Glasser, disponível em Oliveira e Berto (2015), foi feito com uma parede construída com blocos de classe C, com revestimento de $1,5 \mathrm{~cm}$ em argamassa na face exposta ao fogo e dimensões nominais iguais ao bloco simulado em temperatura ambiente no presente trabalho. 
Com o intuito de validar as propriedades térmicas empregadas no bloco, modelou-se o prisma de dois blocos com argamassamento total, já simulado à compressão em temperatura ambiente, com aplicação de revestimento em apenas uma face.

Manteve-se a malha e dimensões empregadas no prisma em temperatura ambiente, alterando a família dos elementos para "transferência de calor" do tipo DC3D8. No revestimento foram empregados 3042 elementos com lados de dimensões aproximadas de 1 $\mathrm{cm}$. Na Figura 57 é apresentada a malha utilizada no prisma revestido.

Figura 57 - Malha utilizada no prisma revestido

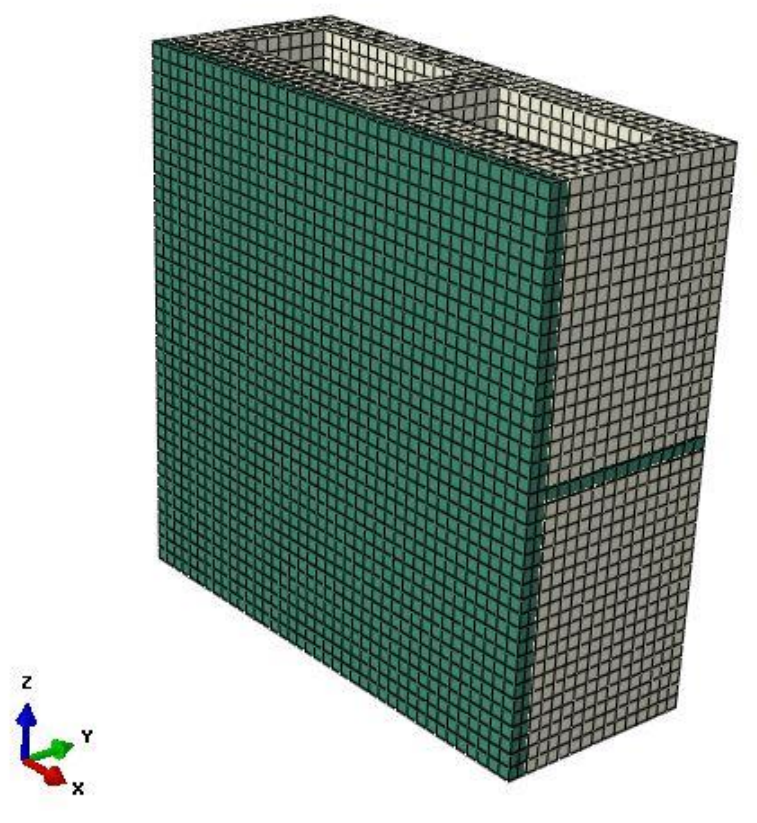

Fonte: Autora (2018)

No relatório de ensaio fornecido pela empresa consta a temperatura inicial de $17^{\circ} \mathrm{C}$. Essa temperatura foi aplicada ao prisma por meio de um passo inicial e durante a etapa de incêndio, considerou-se que a face não exposta ao fogo perdia calor para o ambiente por meio da convecção e radiação. Na face exposta ao incêndio foi aplicada a elevação de temperatura do forno, a qual ficou bem próxima da curva ISO 834-1:1999, e considerou-se a convecção e radiação como mecanismos de transferência de calor.

Os valores de coeficiente de convecção utilizados nas simulações foram os indicados no Eurocode 1 Parte 1-2:2002. A emissividade utilizada em ambas as faces foi a indicada para o concreto no Eurocode 2 Parte 1-2:2004. Para representar o ar presente nas cavidades utilizou-se da interação fluido-estrutura, onde a transferência de calor ocorre por meio da condução e convecção. Uma vez que no caso anterior as propriedades da cerâmica foram 
alteradas e a elevação de temperatura na projeção de um ponto no centro da cavidade maior, na face não exposta ao fogo, ficou inferior àquela medida na região de mais material. $\mathrm{Na}$ Figura 58 estão presentes os coeficientes utilizados na simulação do prisma revestido.

Figura 58 - Esquema da modelagem térmica do prisma com revestimento em uma face

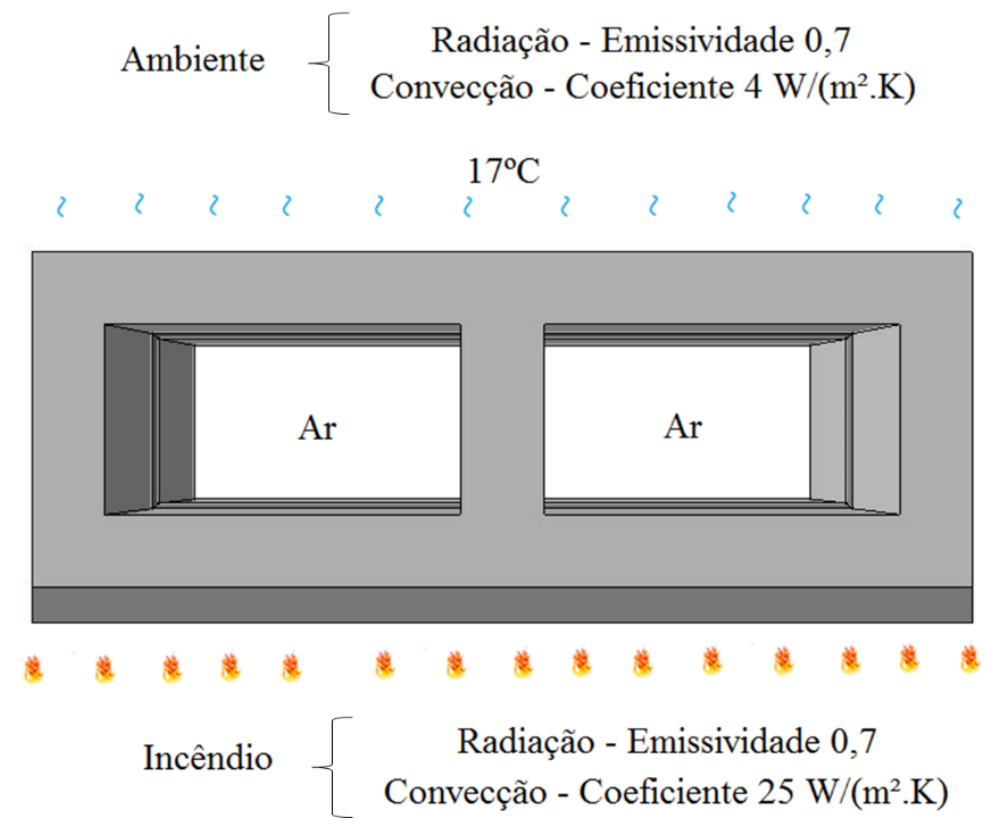

Fonte: Autora (2018)

A massa de ar foi representada com o total de 9360 elementos sólidos da família "fluido" do tipo FC3D8, com lados de dimensões aproximadas de $1 \mathrm{~cm}$. As dimensões externas da massa de ar são equivalentes às dimensões das cavidades. Na massa de ar também foi aplicada a temperatura inicial de $17^{\circ} \mathrm{C}$. A Figura 59 ilustra a malha empregada na massa de ar. 
Figura 59 - Malha utilizada na massa de ar

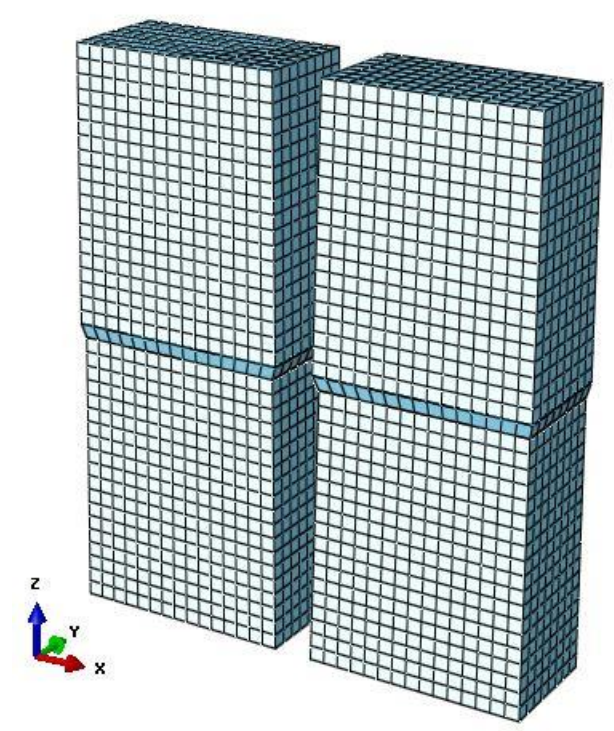

Fonte: Autora (2018)

O software exige as condições de contorno iniciais do fluido, assim, nas extremidades superiores do fluido aplicou-se a pressão de referência zero. A velocidade de $0,01 \mathrm{~m} / \mathrm{s}$ foi aplicada na direção do eixo $\mathrm{Y}$, simulando o movimento do ar. A Figura 60 apresenta os valores de condutividade térmica para diversos materiais, incluindo o ar. 
Figura 60 - Condutividade térmica de diversos materiais

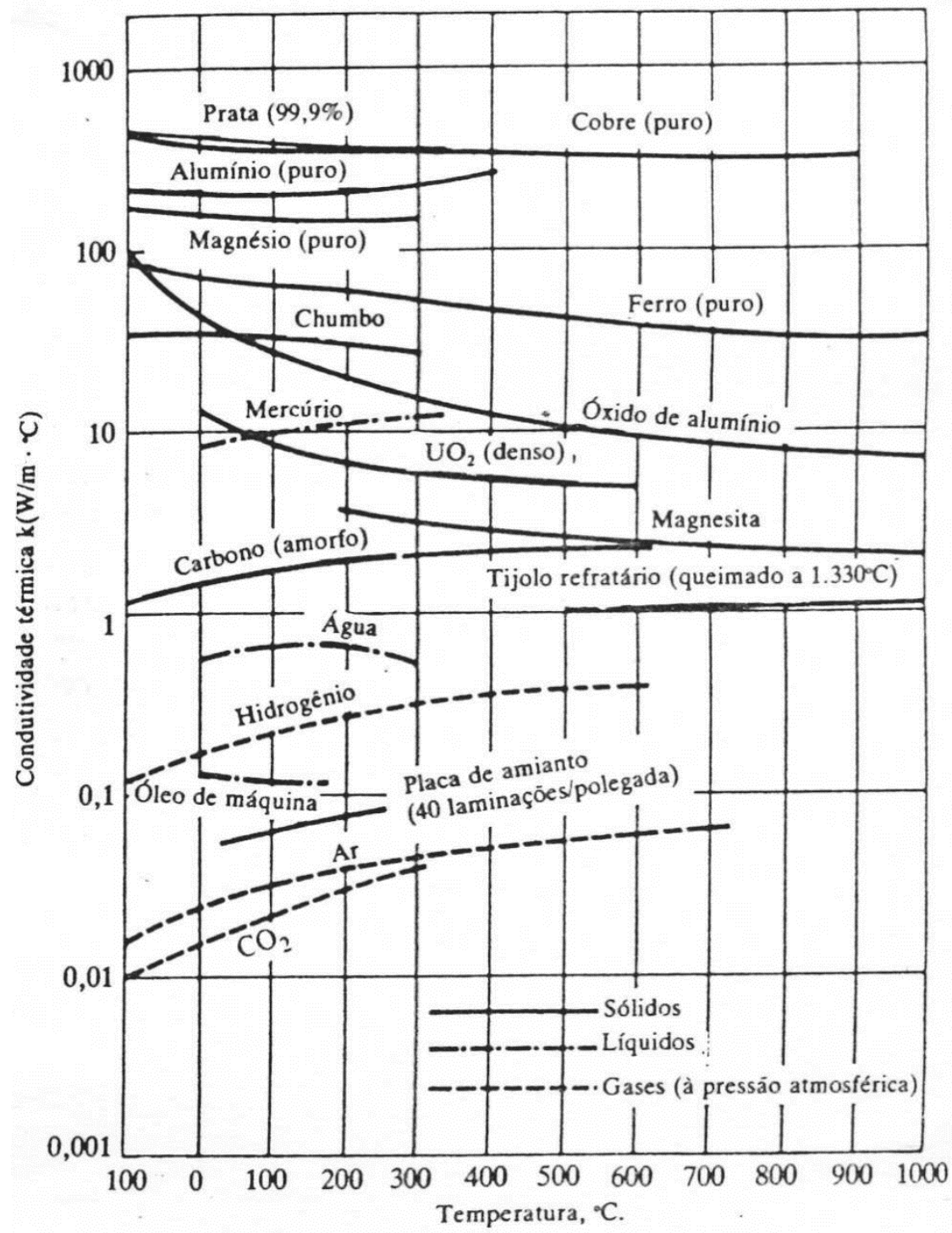

Fonte: Donoso (2009)

Observa-se que a condutividade térmica do ar é muito baixa. Uma vez que nas cavidades, com a interação fluido-estrutura, não foi representada a radiação, os valores de condutividade do ar foram aumentados seguindo a tendência da curva apresentada na Figura 60. Os valores de calor específico do ar utilizados na modelagem foram os indicados em Abbott e Van Ness (2007). Adotaram-se os valores de $1,22 \mathrm{~kg} / \mathrm{m}^{3}$ de massa específica e viscosidade de $1,82 \times 10^{-5} \mathrm{~kg} /(\mathrm{m} . \mathrm{s})$. Na Tabela 17 constam os valores de condutividade térmica e calor específico do ar utilizados na simulação. 
Tabela 17 - Propriedades térmicas do ar utilizadas na simulação

\begin{tabular}{ccc}
\hline $\begin{array}{c}\text { Temperatura } \\
\mathrm{T}\left({ }^{\circ} \mathrm{C}\right)\end{array}$ & $\begin{array}{c}\text { Condutividade térmica } \\
\mathrm{W} /(\mathrm{m} . \mathrm{K})\end{array}$ & $\begin{array}{c}\text { Calor específico } \\
\mathrm{J} / \mathrm{kg} . \mathrm{K})\end{array}$ \\
\hline 17 & 0,100 & 1012 \\
60 & 0,130 & 1017 \\
80 & 0,160 & 1019 \\
100 & 0,200 & 1022 \\
200 & 0,250 & 1035 \\
300 & 0,275 & 1047 \\
400 & 0,290 & 1059 \\
500 & 0,300 & 1076 \\
1000 & 0,300 & 1139 \\
1500 & 0,300 & 1139 \\
\hline
\end{tabular}

Fonte: Adaptado de Abbott e Van Ness (2007)

O teor de umidade da parede foi verificado utilizando-se um prisma representativo. Em Oliveira e Berto (2015) consta o teor de umidade de 2\%. Assim, realizou-se uma interpolação dos valores de calor específico dispostos na Figura 17, obtendo-se o valor de $1664 \mathrm{~J} /(\mathrm{kg} . \mathrm{K})$ para o pico referente à umidade de $2 \%$. A massa específica do bloco de concreto foi calculada com os dados contidos no trabalho de Oliveira (2014), obtendo-se o valor de $2186,73 \mathrm{~kg} / \mathrm{m}^{3}$.

Conforme Chichierchio (1990) a condutividade térmica de um bloco da empresa Tecprem com mesmas dimensões nominais e massa específica de $2150 \mathrm{~kg} / \mathrm{m}^{3}$ é de 1,69 $\mathrm{W} /\left(\mathrm{m} .{ }^{\circ} \mathrm{C}\right)$ em temperatura ambiente. $\mathrm{O}$ valor inicial médio de condutividade térmica apresentado na Figura 16 é 1,68 W/(m.K), bem próximo do valor proposto por Chichierchio (1990), assim, optou-se por utilizar a curva média de condutividade térmica da mesma Figura na simulação numérica.

A massa específica da argamassa foi calculada a partir do traço em massa disponível em Oliveira (2014), obtendo-se o valor de 2179,68 kg/m³. Os valores de calor específico e condutividade térmica empregados na simulação numérica foram os mesmos já especificados na Tabela 15. 


\subsubsection{Validação do prisma com revestimento na face exposta ao fogo}

No ensaio de resistência ao fogo da parede revestida em apenas uma face, foram feitas leituras de temperatura em intervalos de 5 minutos em 11 pontos diferentes da face não exposta ao fogo. A elevação média de temperatura foi calculada com os 5 primeiros pontos em Oliveira e Berto (2015). A temperatura limite do critério de isolamento térmico foi atingida com 104 minutos conforme os valores médios, possuindo então grau de corta-fogo de 90 minutos (CF90), uma vez que o corpo de prova se manteve estanque e estável durante 120 minutos e que o grau de corta-fogo é definido em intervalos de 30 minutos. Não ocorreu o desprendimento do revestimento durante o incêndio.

A validação da modelagem térmica foi feita comparando-se a elevação média de temperatura na face não exposta experimental com os resultados de elevação média de temperatura numérica. As medidas de temperatura na modelagem foram feitas na projeção da cavidade e no centro do prisma, na argamassa e no bloco. Na Figura 61 são apresentados os resultados numérico e experimental da média de elevação de temperatura nas faces não expostas ao fogo.

Figura 61 - Elevação de temperatura nas faces não expostas ao fogo experimental e numérico

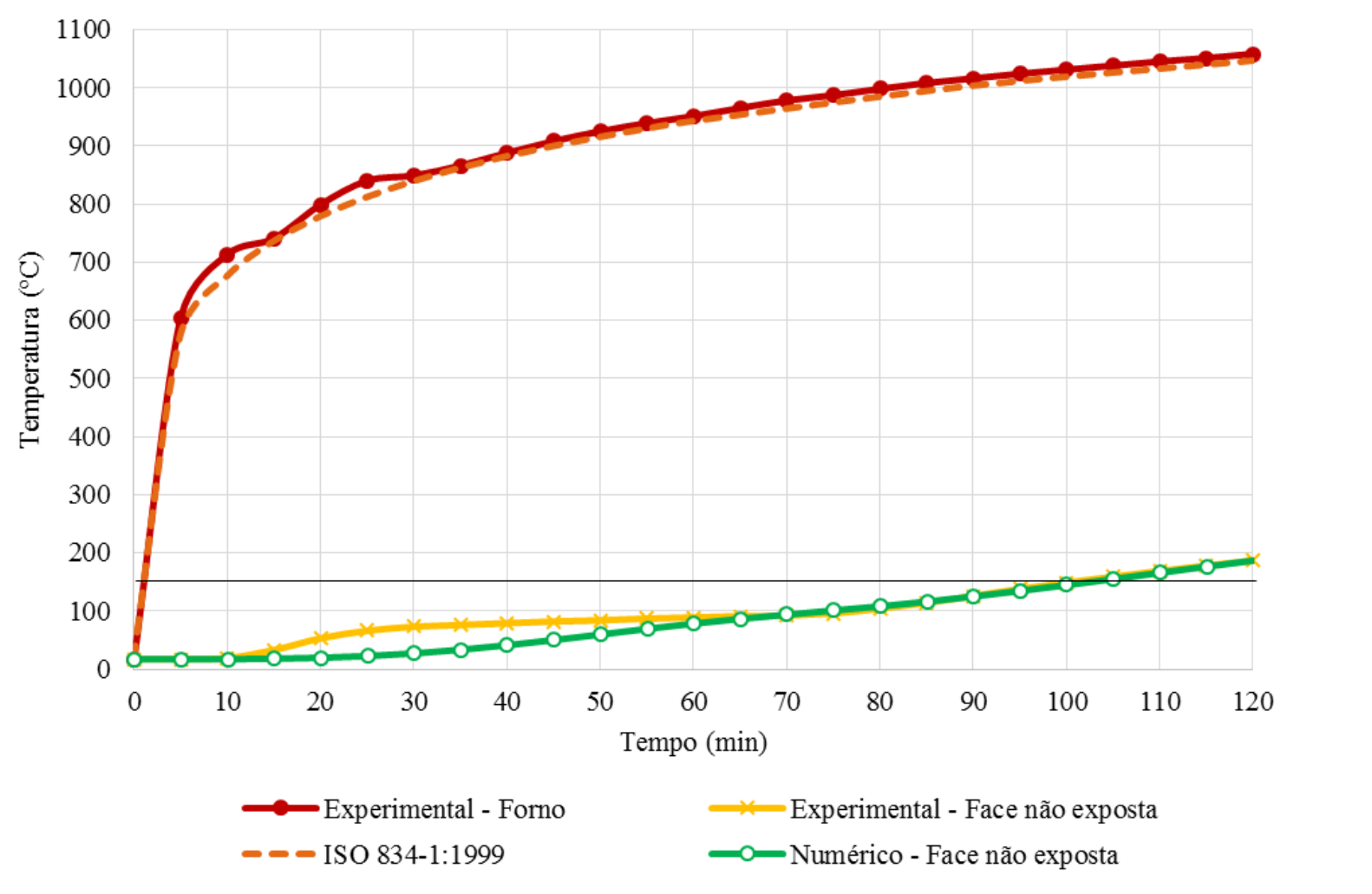

Fonte: Autora (2018) 
Observa-se que inicialmente existe um patamar de elevação de temperatura nos resultados experimentais que não pôde ser representado numericamente. Foram feitos testes alterando-se a condutividade térmica inicial do ar, sem mudança significativa dos resultados. Entretanto, após aproximadamente 35 minutos de incêndio, os resultados experimental e numérico começam a convergir. A temperatura limite do critério de isolamento térmico foi atingida numericamente em 106 minutos, diferindo em apenas 1,92\% dos resultados experimentais.

Os resultados médios de elevação de temperatura nas faces não expostas experimental e numérico em intervalos de 10 minutos estão disponíveis na Tabela 18.

Tabela 18 - Resultados médios de elevação de temperatura nas faces não expostas

\begin{tabular}{|c|c|c|c|}
\hline $\begin{array}{l}\text { Tempo } \\
(\mathrm{min})\end{array}$ & $\begin{array}{c}\text { Experimental } \\
\left({ }^{\circ} \mathrm{C}\right)\end{array}$ & $\begin{array}{c}\text { Numérico } \\
\left({ }^{\circ} \mathrm{C}\right)\end{array}$ & Diferença \\
\hline 0 & 17 & 17 & 0 \\
\hline 10 & 19 & 17 & 2 \\
\hline 20 & 53 & 20 & 33 \\
\hline 30 & 73 & 27 & 46 \\
\hline 40 & 79 & 41 & 38 \\
\hline 50 & 84 & 60 & 24 \\
\hline 60 & 89 & 78 & 11 \\
\hline 70 & 92 & 94 & 2 \\
\hline 80 & 104 & 108 & 4 \\
\hline 90 & 126 & 125 & 1 \\
\hline 100 & 149 & 145 & 4 \\
\hline 110 & 169 & 166 & 3 \\
\hline 120 & 187 & 187 & 0 \\
\hline
\end{tabular}

Fonte: Autora (2018)

Nota-se que as diferenças de temperatura exibidas na Tabela 18 exprimem a tendência ilustrada na Figura 61. Apesar de o experimento ter sido realizado com uma parede constituída por blocos de classe $\mathrm{C}$ e o prisma das simulações por blocos de classe A, espera-se que o campo térmico desenvolvido em ambas as classes seja similar, pois o valor inicial de condutividade térmica empregado nas modelagens foi o indicado para um bloco de classe A da empresa anterior à Glasser, a Tecprem e obteve-se numericamente o mesmo grau de cortafogo para blocos de classe $\mathrm{C}$ do ensaio, CF90, desconsiderando-se os outros critérios. 
Na simulação numérica foram feitas medidas de temperatura em diversos pontos do prisma, sendo esses posicionados no bloco e na junta de argamassa, na projeção da cavidade e centro e diferentes espessuras. A nomeação dos pontos segue as dimensões aproximadas da lateral do bloco em centímetros, sendo que D0 é a face mais próxima do incêndio e D14 a face exposta ao ambiente. A elevação de temperatura desses diferentes pontos está presente na Figura 62.

Figura 62 - Elevação de temperatura em diversos pontos do prisma com revestimento em uma face

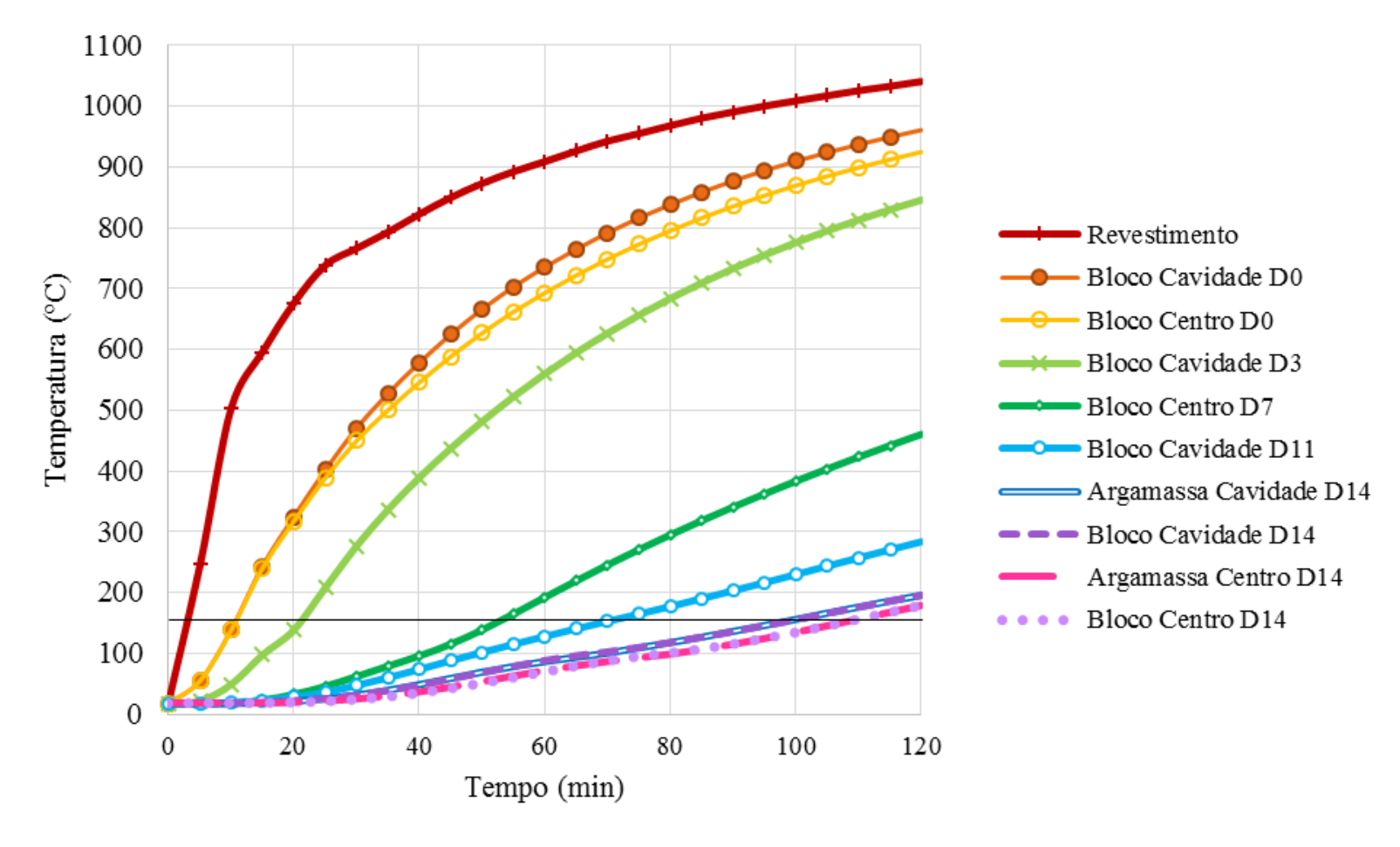

Fonte: Autora (2018)

Observa-se nos resultados numéricos que para pontos situados na mesma distância da face exposta ao fogo, aqueles projetados na cavidade possuem temperatura ligeiramente superior àqueles projetados no centro do prisma. Na Figura 63 estão disponíveis os campos térmicos desenvolvidos no prisma com revestimento em apenas uma face e na massa de ar em intervalos de 30 minutos. 
Figura 63 - Campos térmicos desenvolvidos no prisma com revestimento em uma face e na massa de ar $\left({ }^{\circ} \mathrm{C}\right)$

Prisma

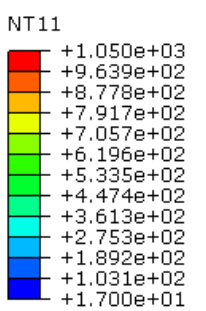

NT11

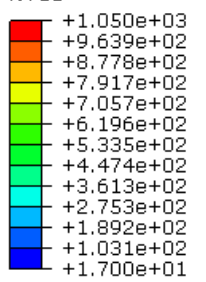

NT11

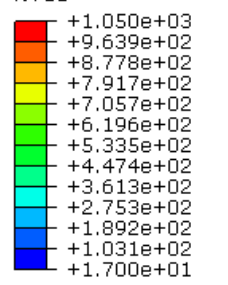

NT 11

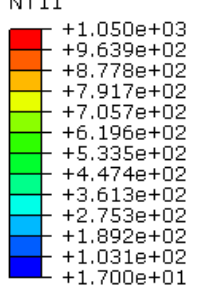

$+1.700 \mathrm{e}+01$

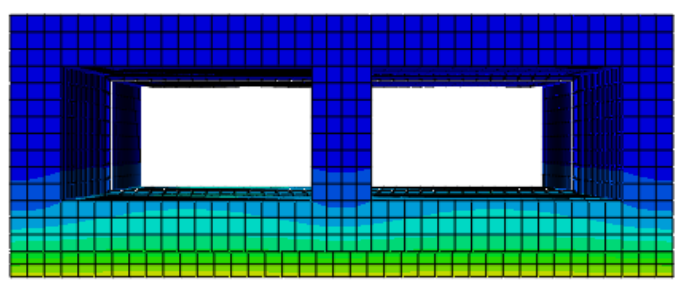

Massa de ar

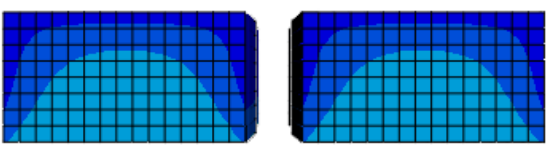

30 minutos
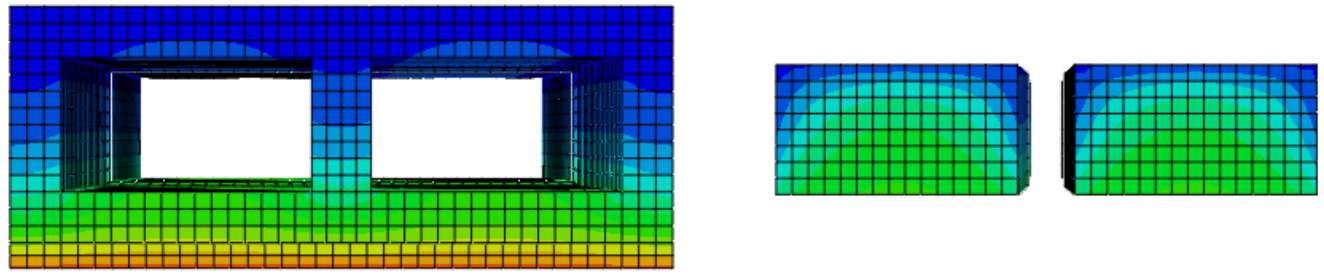

60 minutos
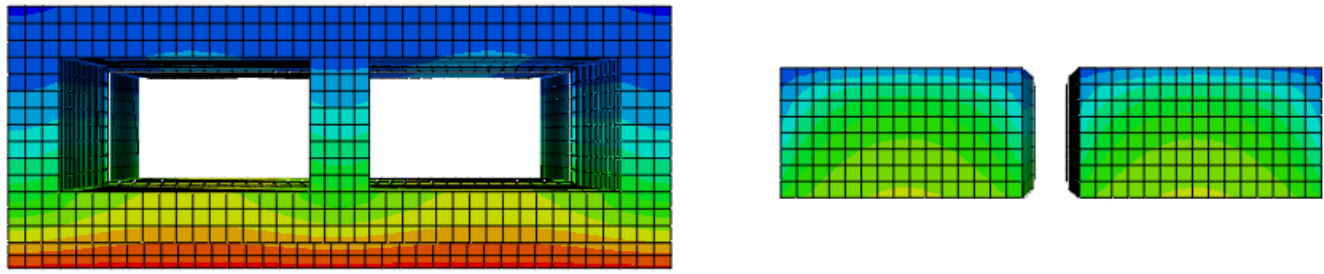

90 minutos
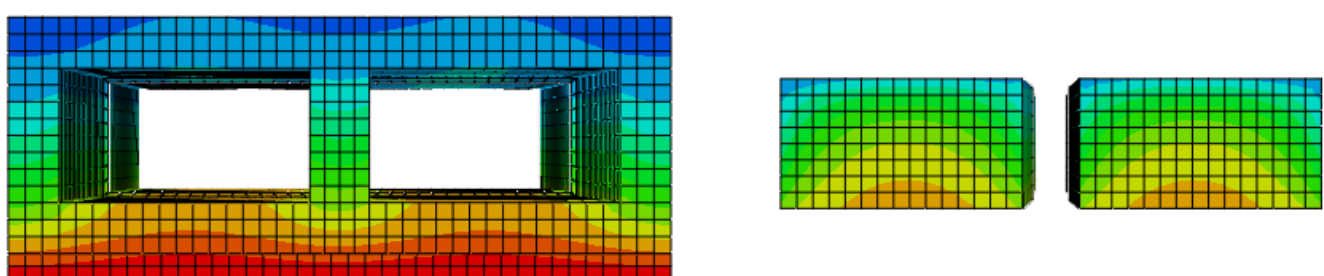

120 minutos

Fonte: Autora (2018)

\subsubsection{Prisma sem revestimento e uma face exposta ao incêndio}

Após se considerarem validadas as propriedades dos materiais utilizados no prisma revestido, simulou-se o comportamento térmico do prisma sem revestimento e com propriedades iguais ao primeiro, aplicando-se a curva de elevação de temperatura ISO 8341:1999 para o incêndio e temperatura ambiente de $20^{\circ} \mathrm{C}$.

Para reduzir o tempo de processamento utilizou-se o plano de simetria comum às análises de compressão e incêndio, uma vez que para a simulação termomecânica é necessária 
a inserção dos campos térmicos obtidos na simulação de incêndio. Os planos de simetria do prisma estão ilustrados na Figura 64.

Figura 64 - Planos de simetria do prisma
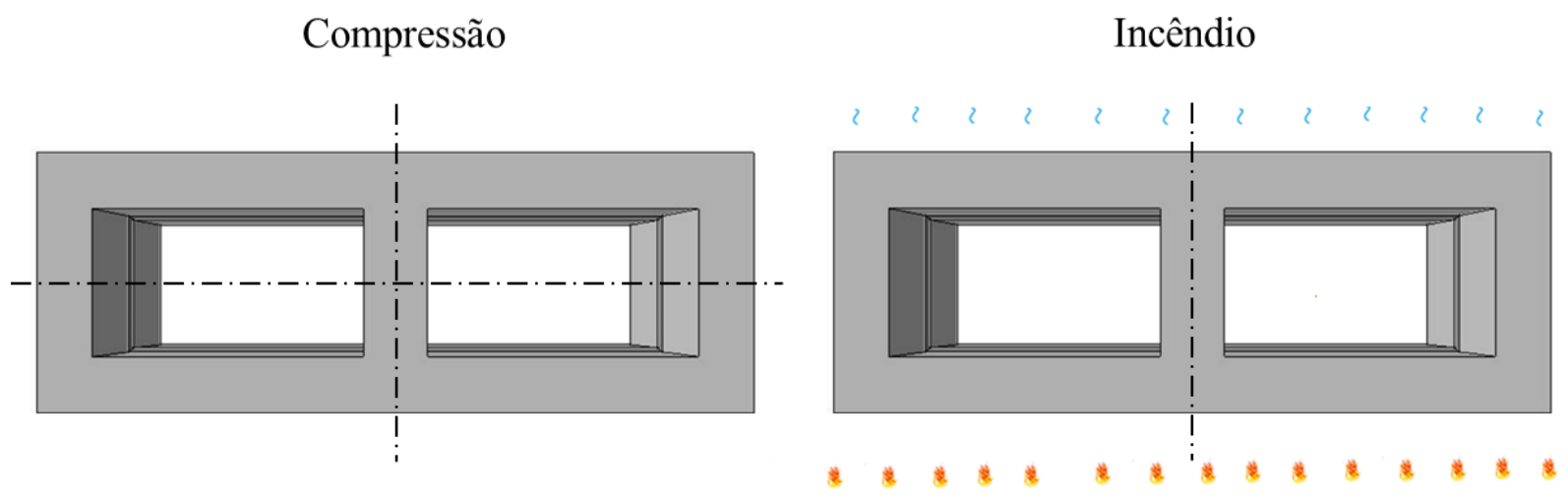

Fonte: Autora (2018)

Manteve-se a mesma malha empregada nas simulações anteriores, entretanto, com a utilização da simetria reduziu-se pela metade o número de elementos. As placas de compressão foram deixadas na análise térmica para serem utilizadas na análise termomecânica, entretanto, não se admitiu a transferência de calor entre os blocos e as placas.

O prisma sem revestimento atingiu a temperatura limite do critério de isolamento térmico numericamente em 86 minutos, equivalente ao grau de corta-fogo CF60, desconsiderando-se os outros critérios. Conforme Chichierchio (1990) uma parede com função portante, nas mesmas condições do prisma e constituída por blocos da empresa Tecprem, possui o mesmo grau de corta-fogo. Na Figura 65 está disponível a elevação de temperatura em diversos pontos do prisma sem revestimento, nomeados da mesma forma que no prisma com revestimento em apenas uma face. 
Figura 65 - Elevação de temperatura em diversos pontos do prisma sem revestimento

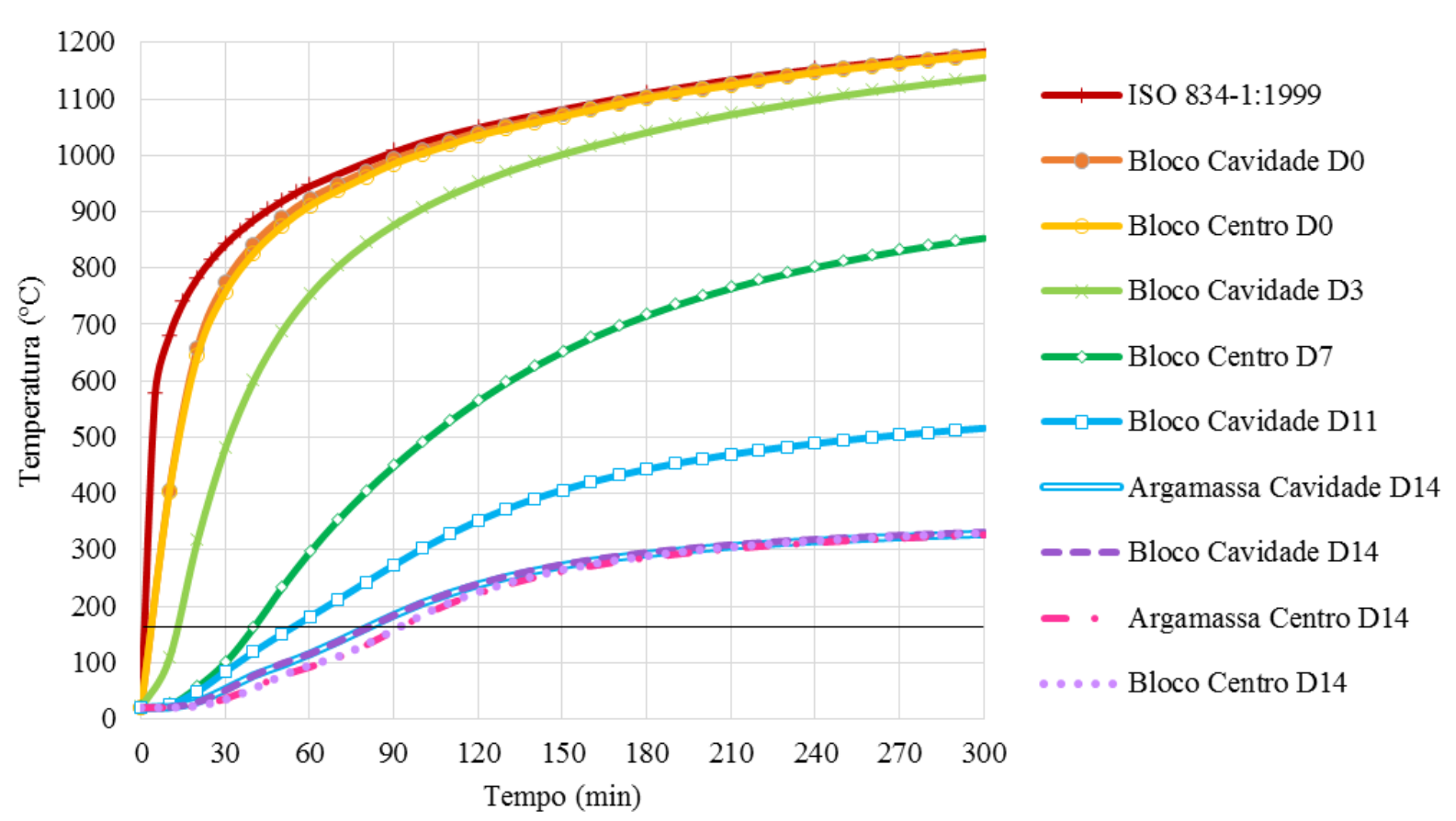

Fonte: Autora (2018)

O incêndio foi simulado durante cinco horas para que esses resultados fossem inseridos na modelagem termomecânica, uma vez que o elemento estrutural ainda resiste às solicitações após a falha do isolamento térmico. Na Figura 66 estão disponíveis os campos térmicos desenvolvidos no prisma e na massa de ar para vários tempos de aquecimento considerando intervalos de 30 minutos. 
Figura 66 - Campos térmicos desenvolvidos no prisma sem revestimento e uma face exposta ao incêndio $\left({ }^{\circ} \mathrm{C}\right)$

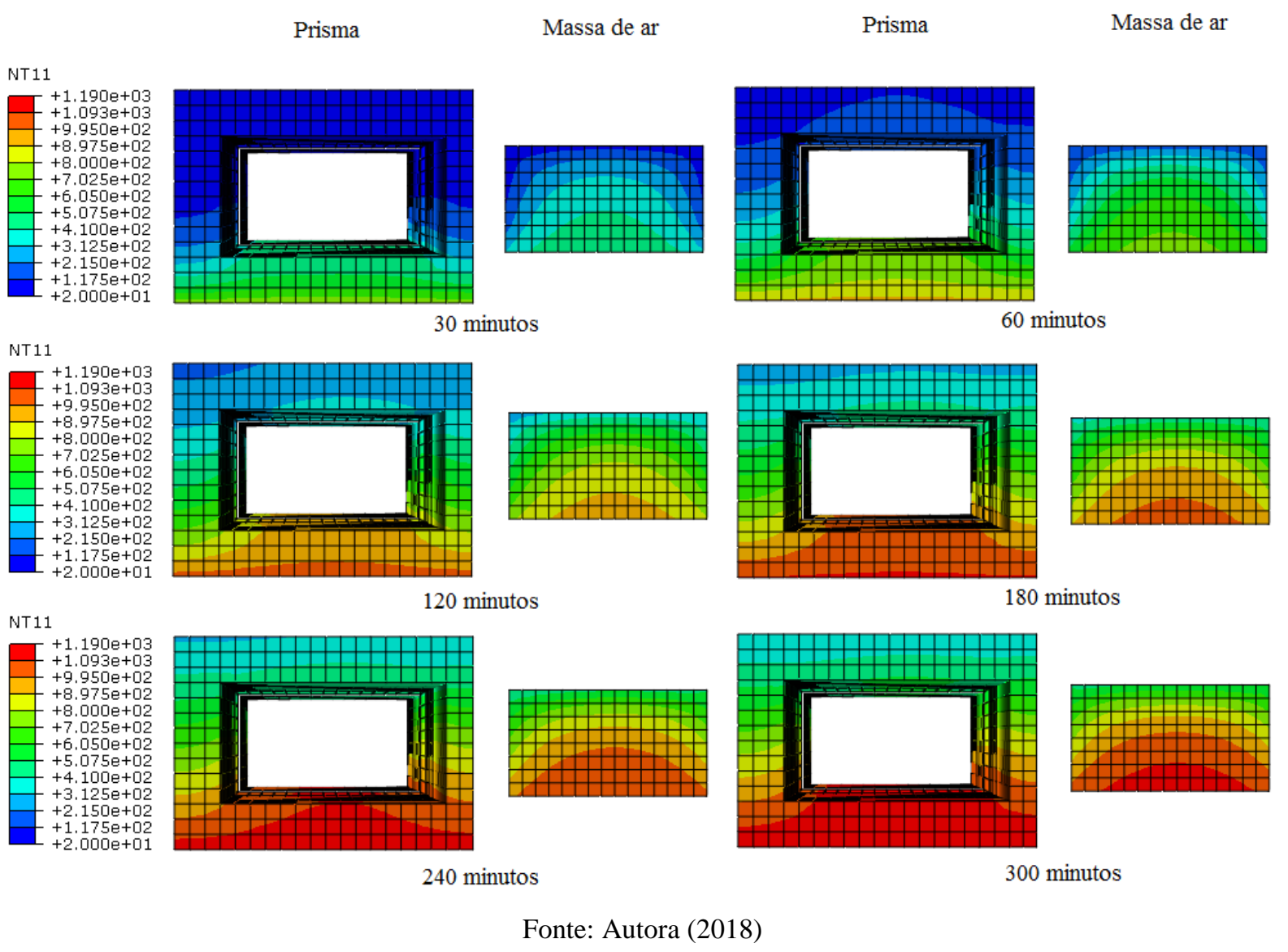

\subsubsection{Prisma com revestimento em argamassa nas duas faces sendo uma exposta ao incêndio}

É comum na alvenaria estrutural que se tenha revestimento em ambas as faces da parede. Assim, optou-se por simular o prisma revestido em argamassa e uma face exposta ao fogo. $\mathrm{O}$ revestimento foi feito com espessura de $1,5 \mathrm{~cm}$ e as propriedades térmicas do bloco, argamassa e massa de ar foram mantidas as mesmas das simulações anteriores. Considerou-se a temperatura ambiente de $20^{\circ} \mathrm{C}$ e transferência de calor entre o prisma e o ambiente através da convecção e radiação, mantendo-se as propriedades anteriores. $\mathrm{O}$ esquema da modelagem térmica do prisma com revestimento em argamassa nas duas faces está presente na Figura 67. 
Figura 67 - Esquema do prisma com revestimento nas duas faces e uma exposta ao fogo

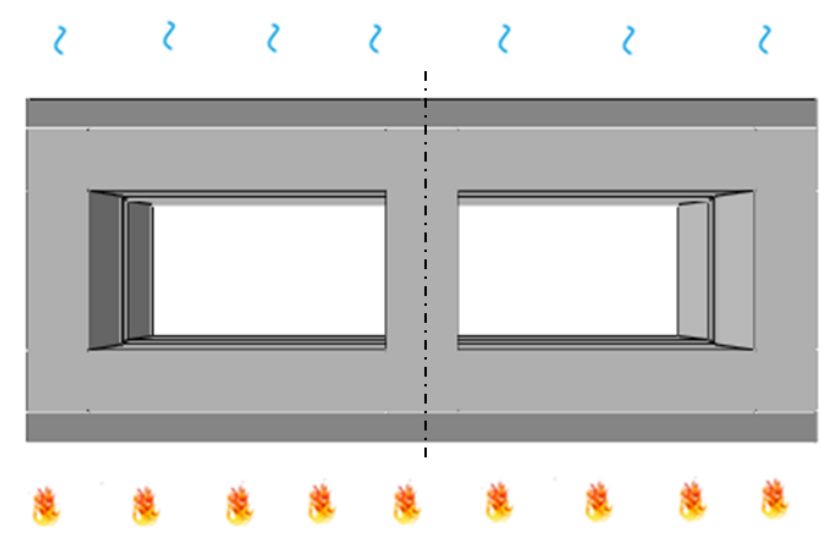

Fonte: Autora (2018)

Para a elevação de temperatura aplicou-se a curva ISO 834-1:1999 na face exposta ao incêndio. A malha utilizada nesta simulação térmica está ilustrada na Figura 68.

Figura 68 - Malha utilizada no prisma com revestimento nas duas faces

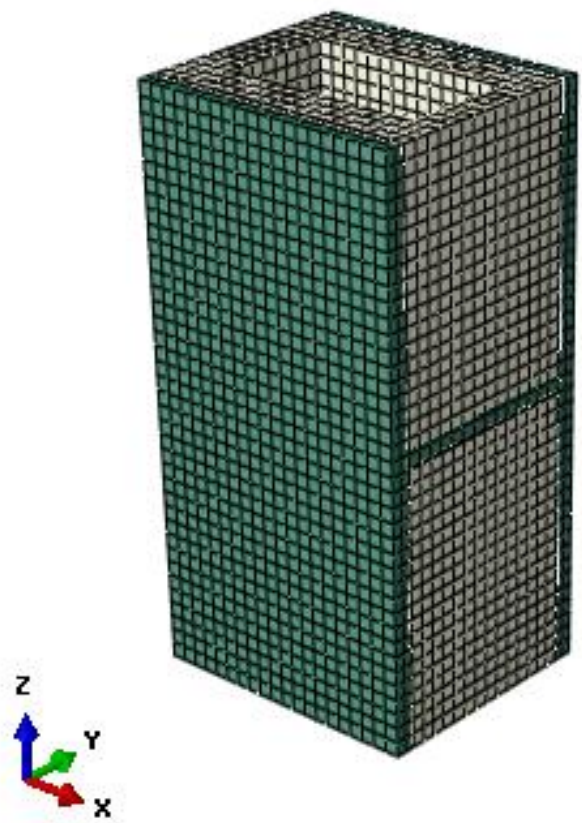

Fonte: Autora (2018)

Neste caso a elevação média de temperatura limite do critério de isolamento térmico foi atingida em 137 minutos. A elevação de temperatura em diversos pontos projetados na cavidade, no centro do prisma e nomeados conforme feito anteriormente estão presentes na Figura 69. 
Figura 69 - Elevação de temperatura em diversos pontos do prisma com revestimento nas duas faces

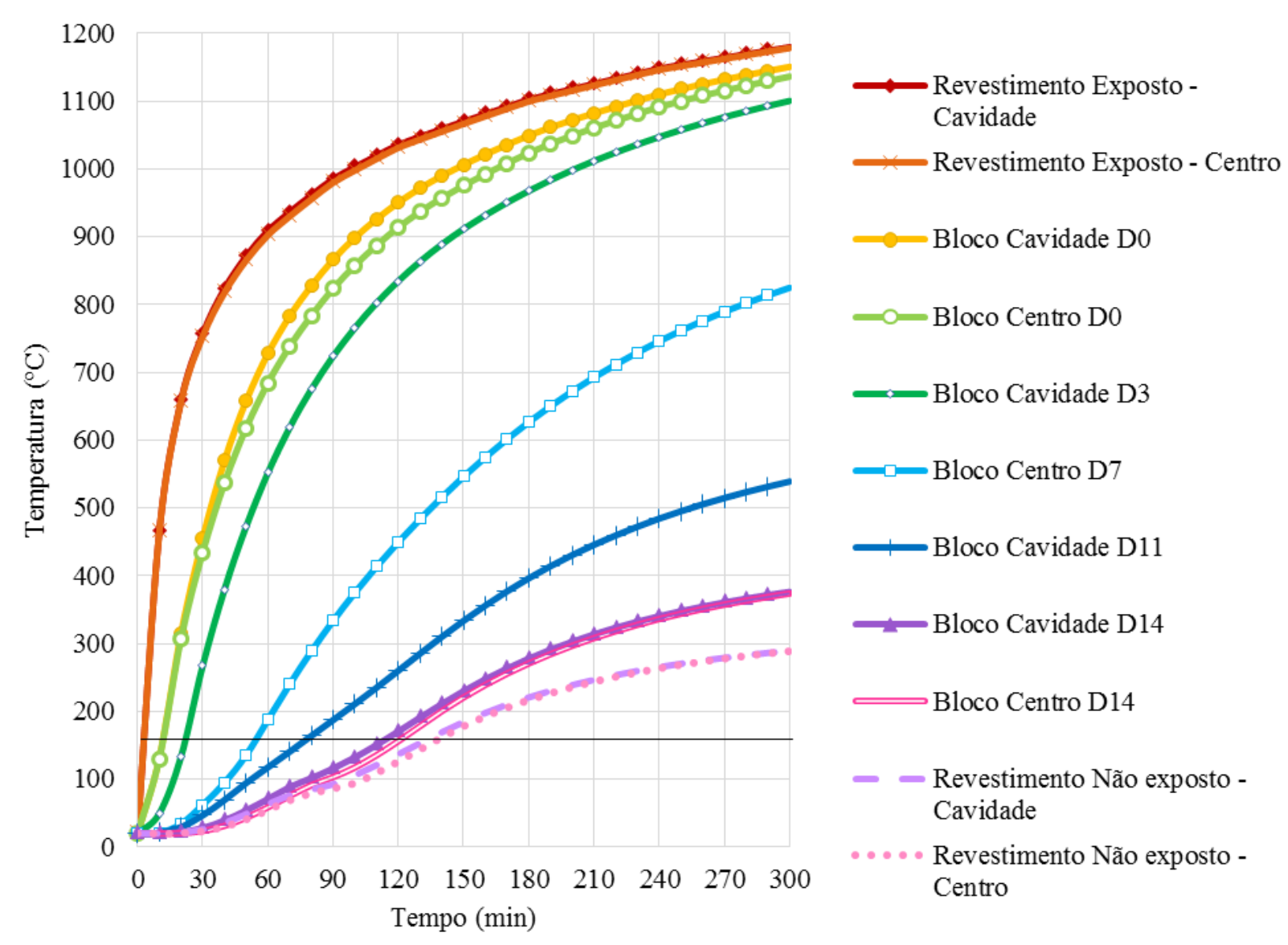

Fonte: Autora (2018)

Na Figura 70 são apresentados os campos térmicos desenvolvidos no prisma com revestimento em duas faces em determinados instantes de incêndio. 
Figura 70 - Campos térmicos desenvolvidos no prisma com revestimento em argamassa nas duas faces $\left({ }^{\circ} \mathrm{C}\right)$

Prisma

NT11
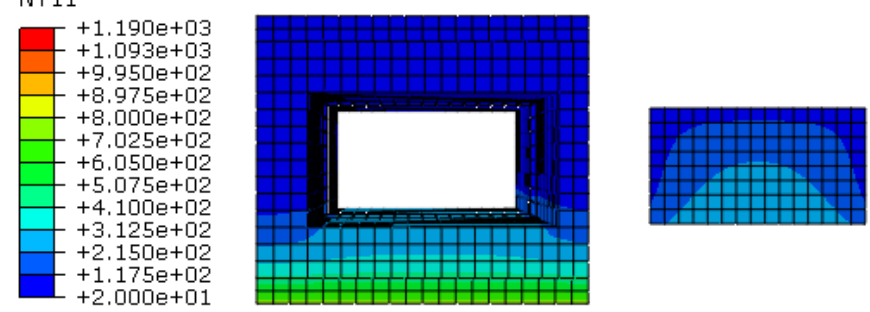

30 minutos

NT11
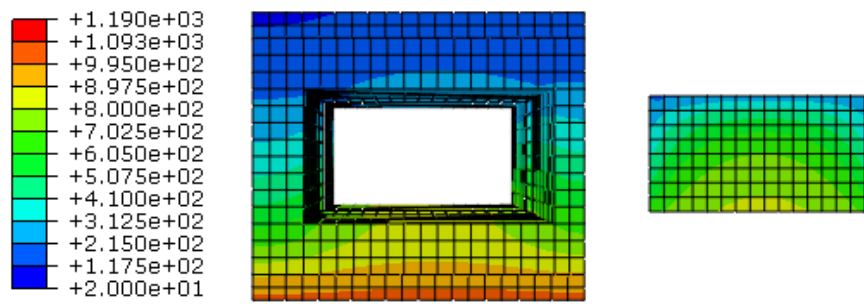

120 minutos

NT11
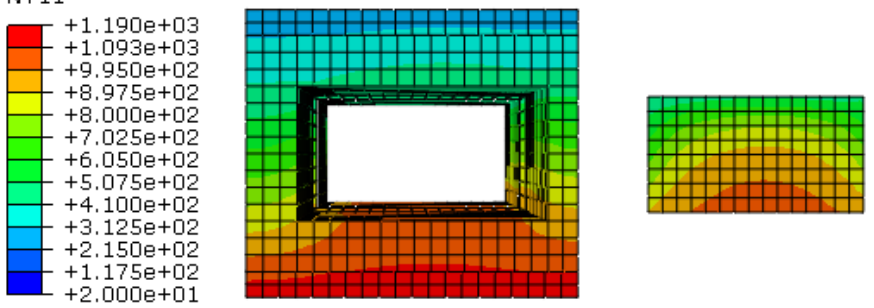

240 minutos
Prisma

Massa de ar
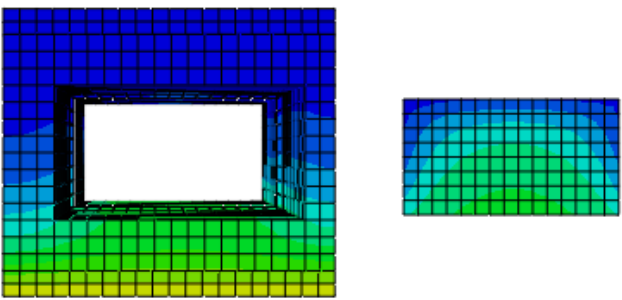

60 minutos
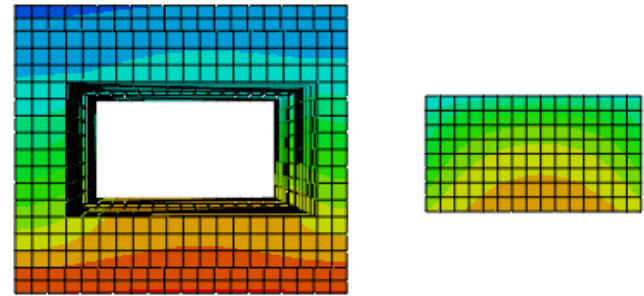

180 minutos

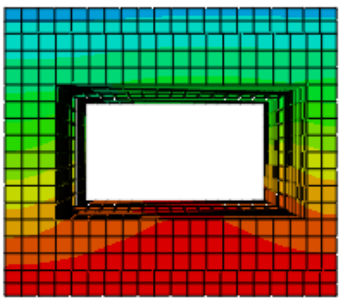

300 minutos

Fonte: Autora (2018) 


\section{SIMULAÇÕES TERMOMECÂNICAS}

Para a modelagem termomecânica é necessária além das propriedades mecânicas do material em temperatura ambiente, a inserção dessas propriedades em elevadas temperaturas. A resistência à compressão do concreto e argamassa foram obtidas por meio do Eurocode 2 Parte 1-2:2004. Essa norma apresenta a variação da razão entre a resistência do material em determinada temperatura e sua resistência inicial $\left(f_{c, \mathrm{~T}} / f_{c k}\right)$, a deformação correspondente à máxima tensão de compressão conforme a temperatura $\left(\varepsilon_{c 1, T}\right)$ e a deformação última $\left(\varepsilon_{c u 1, T}\right)$, adotando-se linear o trecho descendente do diagrama. Na Tabela 19 são apresentados esses parâmetros.

Tabela 19 - Parâmetros do diagrama tensão-deformação do concreto em elevadas temperaturas

\begin{tabular}{ccccc}
\hline $\mathrm{T}\left({ }^{\circ} \mathrm{C}\right)$ & $\begin{array}{c}\text { Agregados silicosos Agregados calcários } \\
f_{c, \mathrm{~T}} / f_{c k}\end{array}$ & $\varepsilon_{c 1, T}$ & $\mathcal{E}_{c u 1, T}$ \\
\hline 20 & 1,00 & 1,00 & 0,0025 & 0,0200 \\
100 & 1,00 & 1,00 & 0,0040 & 0,0225 \\
200 & 0,95 & 0,97 & 0,0055 & 0,0250 \\
300 & 0,85 & 0,91 & 0,0070 & 0,0275 \\
400 & 0,75 & 0,85 & 0,0100 & 0,0300 \\
500 & 0,60 & 0,74 & 0,0150 & 0,0325 \\
600 & 0,45 & 0,60 & 0,0250 & 0,0350 \\
700 & 0,30 & 0,43 & 0,0250 & 0,0375 \\
800 & 0,15 & 0,27 & 0,0250 & 0,0400 \\
900 & 0,08 & 0,15 & 0,0250 & 0,0425 \\
1000 & 0,04 & 0,06 & 0,0250 & 0,0450 \\
1100 & 0,01 & 0,02 & 0,0250 & 0,0475 \\
\hline
\end{tabular}

Fonte: Eurocode 2 Parte 1-2:2004

Observa-se que na Tabela 19 não existem valores de perda de resistência para concreto com basalto. Assim, utilizaram-se as propriedades do concreto com agregados silicosos para o material do bloco e argamassa, pois o agregado miúdo do concreto e argamassa é a areia. O módulo de elasticidade dos materiais dependente da temperatura foi obtido traçando-se a curva tensão-deformação a partir da Equação 24 e calculando-se a inclinação do trecho retilíneo entre 5 e $33 \%$ da resistência à compressão. 


$$
\sigma_{(T)}=\frac{3 \varepsilon f_{c, T}}{\varepsilon_{c 1, T}\left(2+\left(\frac{\varepsilon}{\varepsilon_{c 1, T}}\right)^{3}\right)}
$$

onde:

$\varepsilon \leq \varepsilon_{c 1, T}$

A Figura 71 apresenta o diagrama tensão-deformação simplificado sugerido pelo Eurocode 2 Parte 1-2:2004 para simulações numéricas.

Figura 71 - Diagrama tensão-deformação simplificado

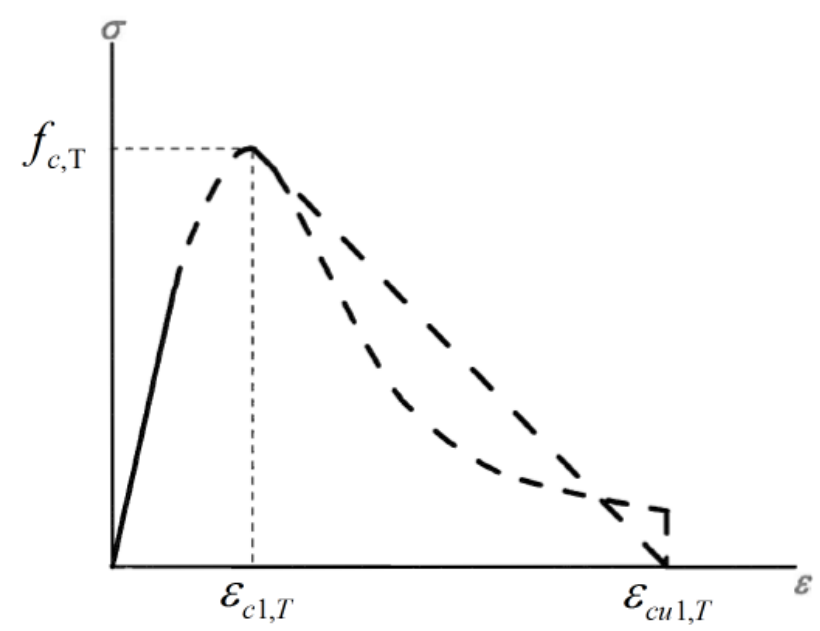

Fonte: Eurocode 2 Parte 1-2 (2004)

As deformações correspondentes à máxima tensão e deformações últimas do concreto e argamassa foram calculadas fazendo-se proporção entre os valores da Tabela 19 e os valores da temperatura ambiente. Por fim, os valores de módulo de elasticidade, resistência à compressão e deformação correspondente à máxima tensão foram inseridos na Equação 21, utilizando-se o mesmo modelo de curva para o trecho ascendente já empregado em temperatura ambiente, em elevadas temperaturas. O dano à compressão foi calculado conforme a Equação 22. Nas Figuras 72 e 73 estão ilustradas as curvas tensão-deformação conforme a temperatura, empregadas nos blocos e argamassa. 
Figura 72 - Curvas tensão-deformação conforme a temperatura do bloco

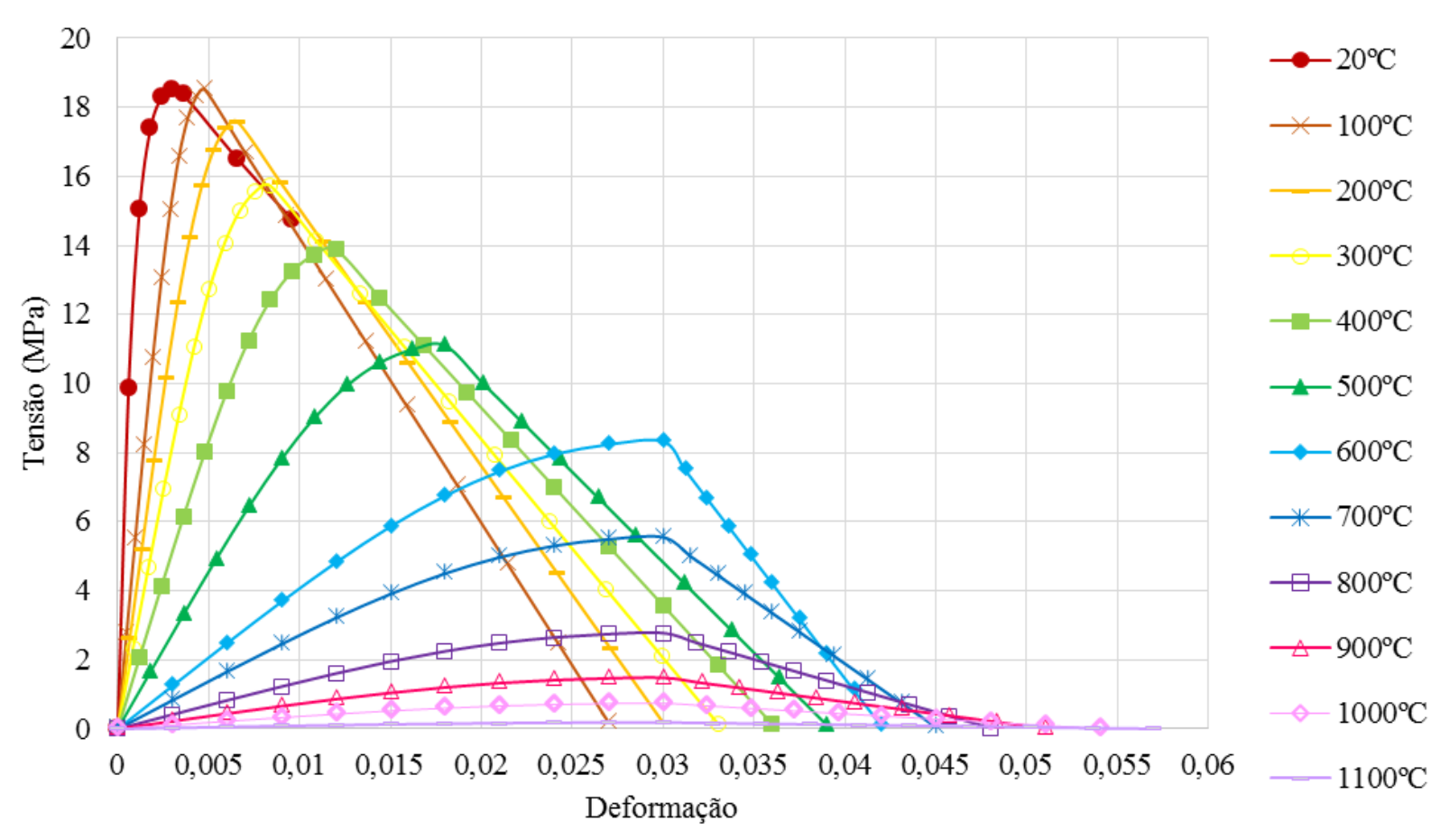

Fonte: Autora (2018)

Figura 73 - Curvas tensão-deformação conforme a temperatura da argamassa

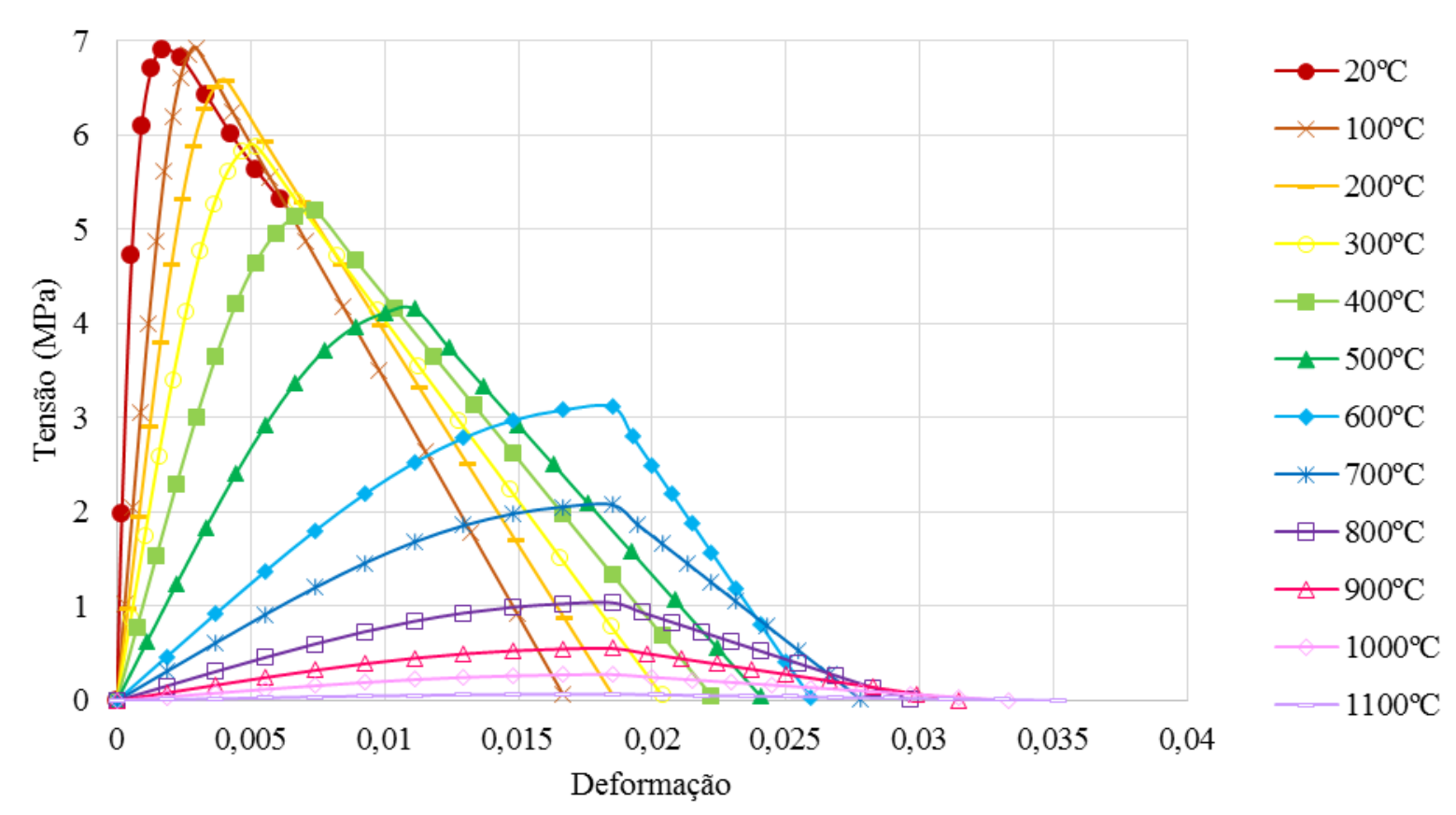

Fonte: Autora (2018) 
As curvas correspondentes à temperatura de $20^{\circ} \mathrm{C}$ não foram simplificadas, utilizaram-se as mesmas já empregadas na compressão do prisma em temperatura ambiente. As curvas referentes às temperaturas de 100 e $1100^{\circ} \mathrm{C}$ foram retiradas da simulação devido a problemas de convergência, ocorridos provavelmente porque na temperatura de $100^{\circ} \mathrm{C}$ mantem-se a resistência inicial com um módulo de elasticidade inferior ao de $20^{\circ} \mathrm{C}$ e em $1100^{\circ} \mathrm{C}$ os valores de tensão são baixos, próximos de zero.

A resistência à tração em elevadas temperaturas do concreto e argamassa foi calculada proporcionalmente à razão (resistência à tração)/(resistência à compressão) em temperatura ambiente. A energia de fratura à tração do concreto foi calculada por meio da Equação 23, enquanto a da argamassa foi calculada por meio de proporção com o valor em temperatura ambiente e a perda de resistência apresentada na Tabela 19.

Os coeficientes de dilatação linear para o bloco e para a argamassa foram adotados como 9,0 × $10^{-6}{ }^{\circ} \mathrm{C}^{-1}$, sendo este o único valor sugerido pela ABNT NBR 15961-1:2011 para o caso de ausência de dados experimentais, com temperatura de referência de $20^{\circ} \mathrm{C}$. Acima de $800^{\circ} \mathrm{C}$ considerou-se que os materiais não se dilatam, conforme a Figura 18.

O carregamento foi aplicado na placa superior por meio de um passo inicial em pequenos incrementos. Em seguida se iniciou o passo de incêndio, no qual se inserem os dados de temperatura nodais dos elementos obtidos na modelagem térmica. Verificou-se o caso de carregamento constante durante a simulação de incêndio, conforme especifica a ABNT NBR 5628:2001.

De acordo com a ABNT NBR 5628:2001 o carregamento aplicado deve ser da mesma ordem de grandeza dos produzidos em situação de uso, em temperaturas normais. Assim, inicialmente foi calculada a resistência característica à compressão dos 12 prismas ensaiados por Oliveira (2014) e se estimou a resistência característica do prisma simulado, uma vez que a comparação para validação da modelagem foi feita através dos valores médios de resistência.

Em seguida estimou-se qual seria o valor de carregamento aplicado em uma parede constituída com os mesmos materiais do prisma. Para isso considerou-se que a resistência da parede é cerca de $70 \%$ da resistência do prisma, o coeficiente redutor devido à esbeltez da parede estimado em 0,85 , o coeficiente de ponderação de resistência $\gamma_{\mathrm{m}}$ da alvenaria conforme a ABNT NBR 15961-1:2011 e o coeficiente de ponderação para combinações normais de ações permanentes de 1,4 .

Esse resultado foi arredondado para $20 \%$ da resistência característica do prisma, equivalente à cerca de $30 \%$ da resistência característica de uma parede constituída pelos 
mesmos materiais. Esse cálculo resultou em uma tensão média de 0,84 MPa a ser aplicado na área da placa, ou 1,78 MPa referente à área líquida do prisma. Aplicou-se também o que seria teoricamente o "carregamento em serviço do prisma", com o valor de $35 \% \mathrm{f}_{\mathrm{pk}}$.

Conforme a ABNT NBR 5628:2001 as vinculações e apoios devem ser feitos de acordo com as condições de uso. Russo e Sciarretta (2013) apresentaram em seu trabalho um esquema de uma parede carregada com a extremidade inferior engastada e a superior com engaste móvel, possibilitando o deslocamento vertical da parede, conforme ilustra a Figura 74.

Figura 74 - Esquema de vinculação de uma parede carregada

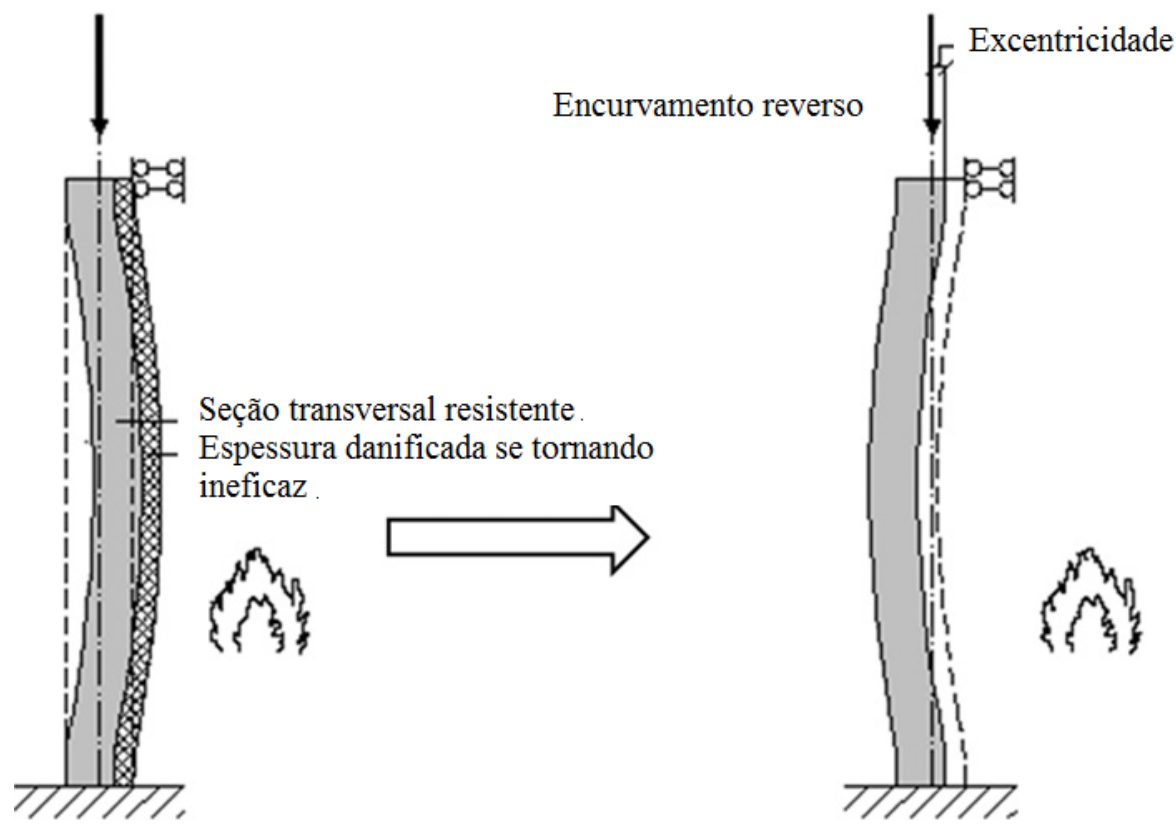

Fonte: Russo e Sciarretta (2013)

Nguyen e Meftah (2012) utilizaram em seus experimentos uma viga para a distribuição dos esforços gerados por células de carga fixas horizontalmente. Os autores não apresentam informações sobre a restrição rotacional. Já a extremidade inferior foi unida a uma base de concreto com junta de argamassa.

Nadjai et al. (2003) afirmam que existe uma restrição rotacional nos experimentos. Após a rotação da extremidade superior da parede no valor de um ângulo $\theta_{\text {lim }}$ desconhecido, a placa gera um momento fletor adicional, apresentado na Figura 75. 
Figura 75 - Momento fletor adicional devido à restrição rotacional

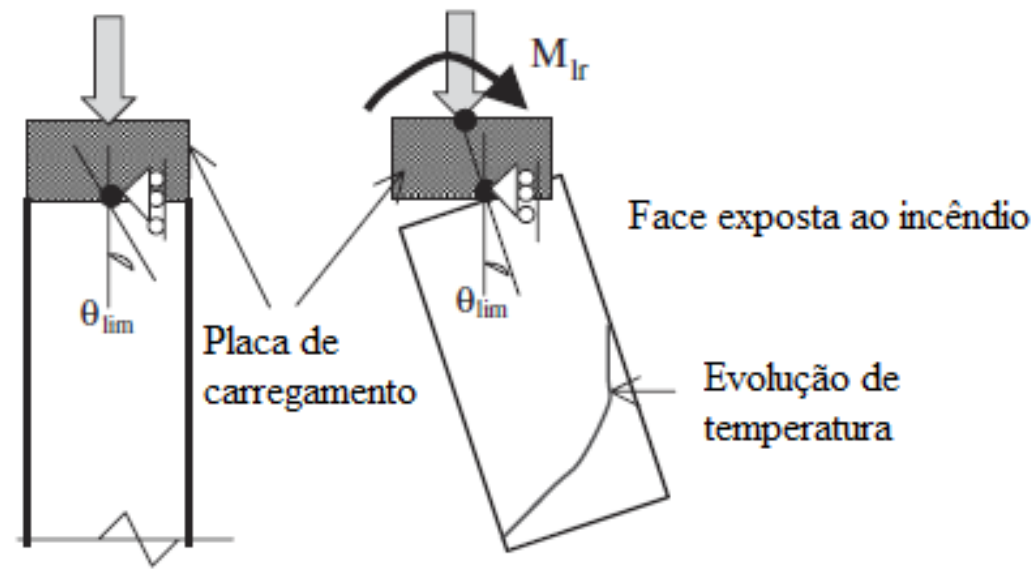

Fonte: Nadjai et al. (2003)

As condições de contorno da placa inferior foram mantidas conforme a simulação de compressão em temperatura ambiente. Para a placa superior foi necessária a criação de um nó de referência, possibilitando o impedimento do giro provocado pela dilatação diferencial. Verificaram-se os casos com e sem restrição rotacional. Conforme feito em Rigão (2012) analisou-se também o caso de restrição de deslocamento vertical após a aplicação do carregamento. Devido à utilização da simetria no plano formado pelos eixos $\mathrm{Z}$ e Y, restringiuse o deslocamento em $\mathrm{X}$ de todo o centro do prisma e placas. $\mathrm{O}$ esquema da simulação termomecânica do prisma está presente na Figura 76. 
Figura 76 - Esquema da simulação termomecânica do prisma sem revestimento
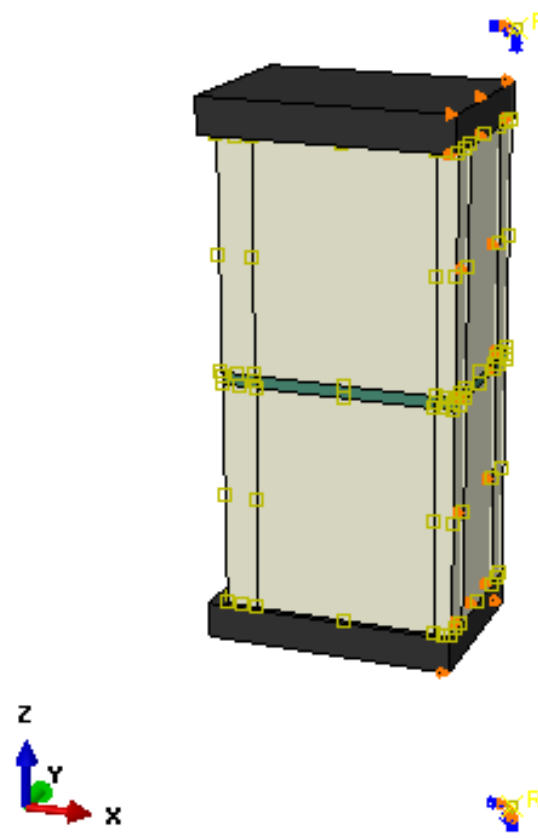

Fonte: Autora (2018)

\subsection{PRISMA SEM REVESTIMENTO E COM DUAS FACES EXPOSTAS AO INCÊNDIO}

A fim de verificar a ruptura do prisma em uma situação onde a restrição rotacional da placa de compressão não influenciaria os resultados, simulou-se o prisma sem revestimento e com duas faces expostas ao incêndio; situação esta em que hipoteticamente a parede é carregada e existe a possibilidade de propagação das chamas para o lado oposto por meio de uma abertura, ou seja, parede sem a função de separação. Apesar da pouca possibilidade de se ter a mesma intensidade de incêndio em ambos os lados e no mesmo instante, aplicou-se a curva ISO 834-1:1999 nas duas faces do prisma, conforme ilustra a Figura 77, com objetivo exploratório. 
Figura 77 - Esquema do prisma sem revestimento com as duas faces expostas ao incêndio

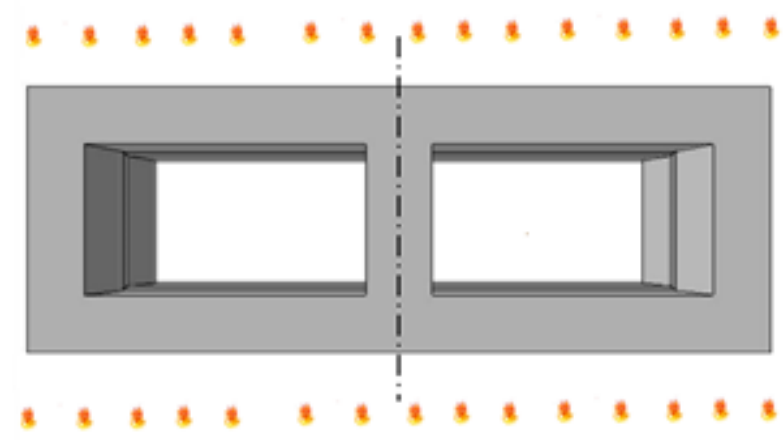

Fonte: Autora (2018)

Considerou-se como temperatura inicial $20^{\circ} \mathrm{C}$ e foi simulada a aplicação de carregamento nos valores de 20 e $35 \%$ da resistência característica do prisma.

\subsubsection{Resultados e comparações}

Esta simulação de incêndio foi feita durante três horas e a elevação de temperatura em diferentes pontos do prisma está presente na Figura 78. 
Figura 78 - Elevação de temperatura em alguns pontos do prisma sem revestimento e com duas faces expostas ao incêndio

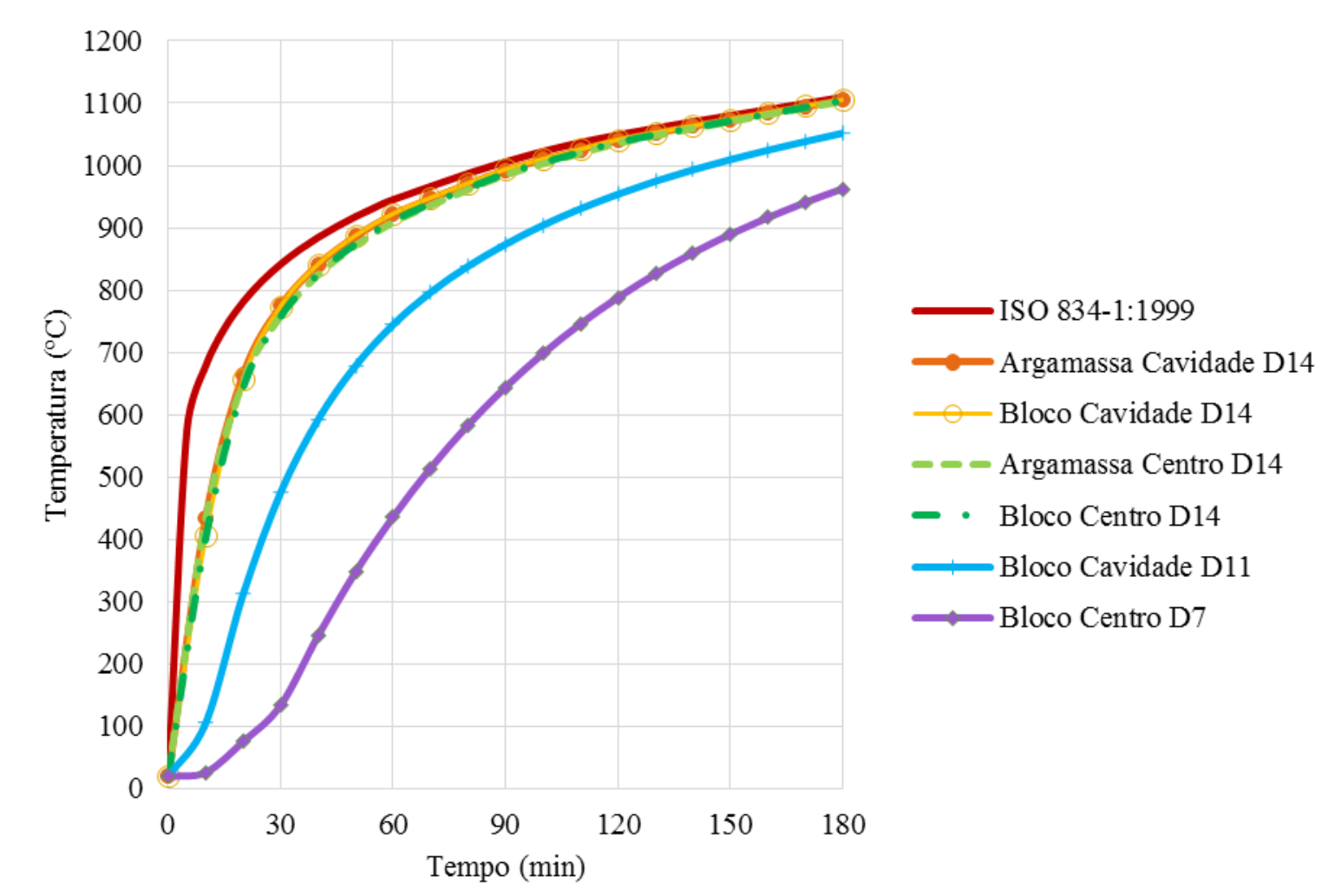

Fonte: Autora (2018)

Neste caso foram apresentados resultados de menos pontos devido à simetria do fluxo de calor, ou seja, os pontos denominados D0 e D3 apresentam elevações de temperatura iguais aos pontos D14 e D11 respectivamente. Os campos térmicos desenvolvidos nos blocos e argamassa estão presentes na Figura 79. 
Figura 79 - Campos térmicos desenvolvidos no prisma sem revestimento e com duas faces expostas ao incêndio $\left({ }^{\circ} \mathrm{C}\right)$

Bloco

NT11

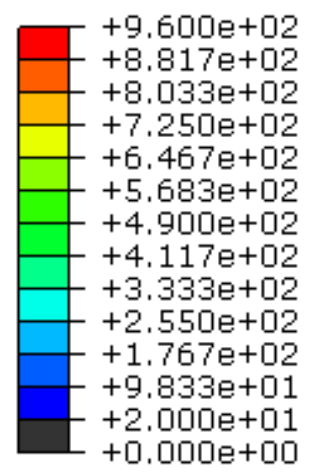

NT11

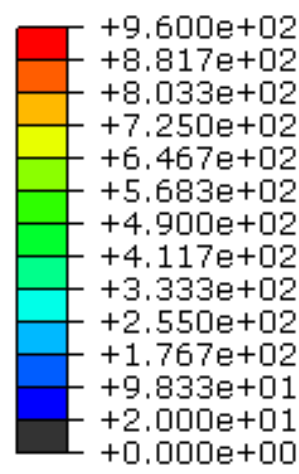

NT 11

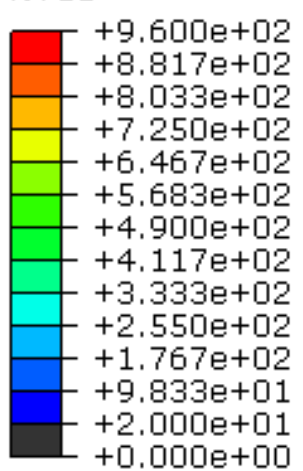

NT11

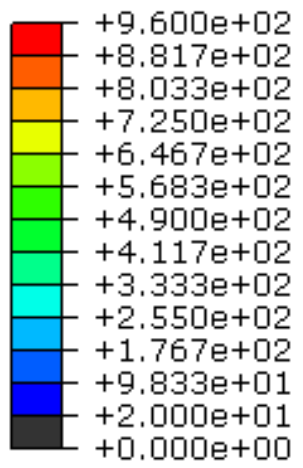

Argamassa
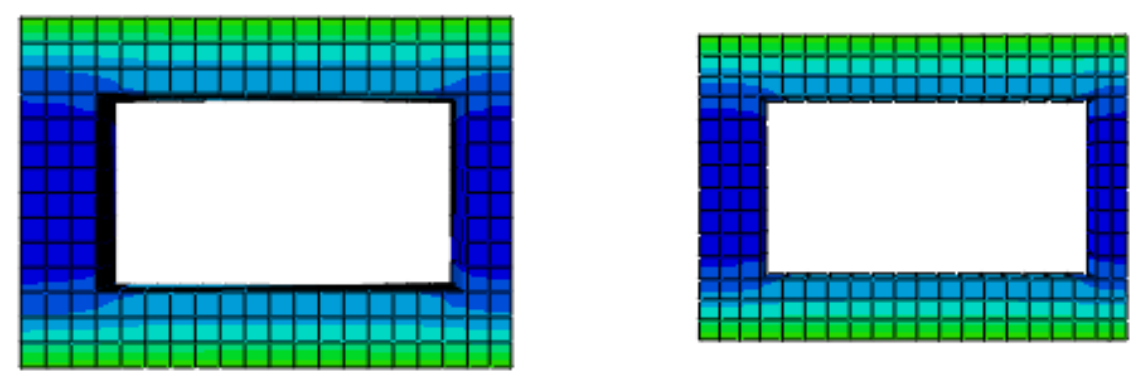

15 minutos
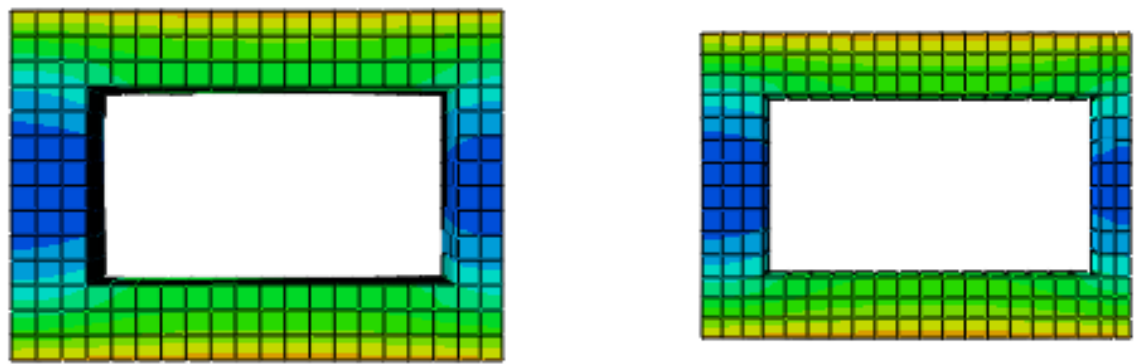

30 minutos
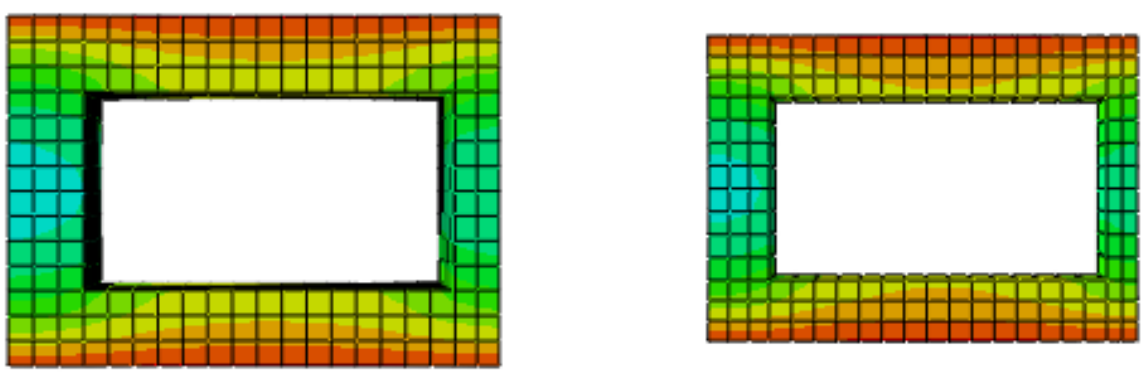

52 minutos
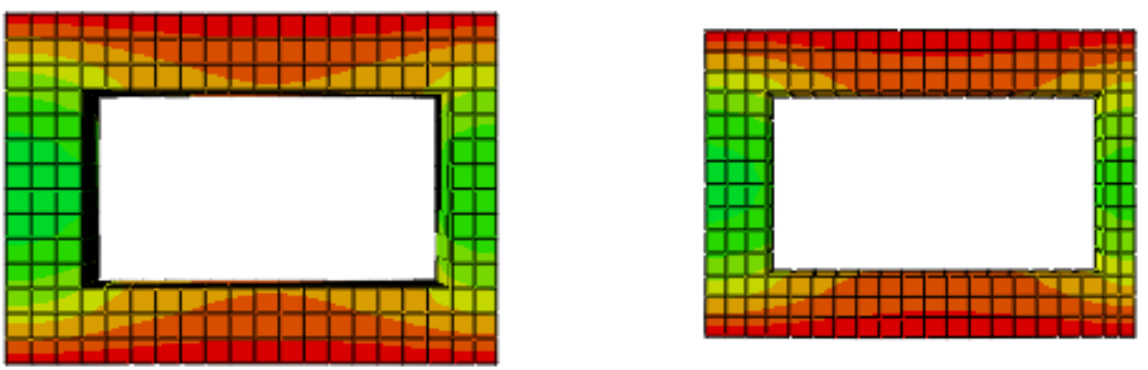

73 minutos 
Na Figura 79 foram apresentados os campos térmicos referentes aos tempos de 52 e 73 minutos de incêndio, pois, apesar da simulação térmica ter sido processada durante 180 minutos, esses foram os instantes limites de convergência do software para a modelagem termomecânica referente aos carregamentos de 35 e $20 \% \mathrm{f}_{\mathrm{pk}}$, respectivamente. A Figura 80 apresenta a deformação axial central do prisma carregado sem restrição vertical e submetido a elevadas temperaturas em duas faces.

Figura 80 - Deformação axial do prisma sem revestimento e com duas faces expostas ao incêndio

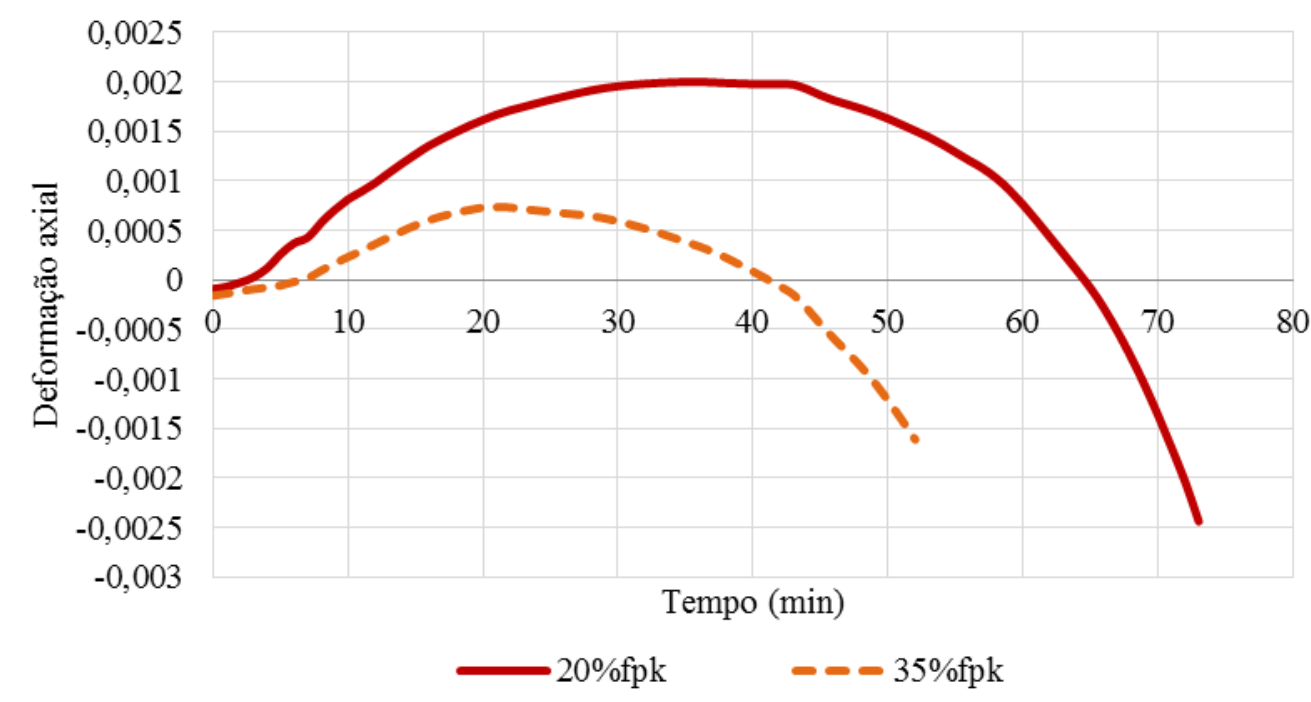

Fonte: Autora (2018)

Observa-se que o prisma possui pequenos valores de deformação axial inicialmente, $9 \times 10^{-5}$ e $1,6 \times 10^{-4}$ para os carregamentos de 20 e $35 \% \mathrm{f}_{\mathrm{pk}}$, respectivamente. Com a elevação de temperatura os materiais se dilatam e após determinados intervalos de tempo, o prisma começa a se encurtar devido à deterioração térmica dos materiais.

A ISO 834-1:1999 apresenta dois critérios para se considerar a ruptura do elemento estrutural carregado axialmente, os quais estão descritos nas Equações 25 e 26.

Limite de contração axial: $C=\frac{h}{100}(\mathrm{~mm})$

Limite da taxa de contração axial: $\frac{d C}{d t}=\frac{3 h}{1000}(\mathrm{~mm} / \mathrm{min})$

onde $h$ é a altura inicial do elemento em milímetros. 
O prisma carregado com 20 e $35 \% \mathrm{f}_{\mathrm{pk}}$ com duas faces em situação de incêndio não atingiu esses limites. Outras normas, como Eurocode 6 Parte 1-2:2005 e ABNT NBR 5628:2001, não definem claramente algum critério de ruptura, apenas mencionam a capacidade do elemento de resistir aos esforços para os quais foi projetado durante determinado tempo de incêndio. Assim, optou-se por analisar os resultados finais obtidos através do Abaqus.

Com a distribuição de temperatura nos materiais, fez-se uma estimativa de suas capacidades resistentes com as curvas tensão-deformação das Figuras 72 e 73, as quais foram inseridas no software para a modelagem termomecânica. Para o tempo de 73 minutos, uma região de aproximadamente $67 \mathrm{~cm}^{2}$, considerando o bloco inteiro, está submetida a temperaturas em torno de $500^{\circ} \mathrm{C}$ (tons de verde da Figura 79). Nessas condições o bloco ainda suporta uma força de $73,7 \mathrm{kN}$ desconsiderando o restante do material que está em outras faixas de temperatura, enquanto a força equivalente a $20 \% \mathrm{f}_{\mathrm{pk}}$ aplicada no prisma é de aproximadamente $53 \mathrm{kN}$. Assim, a ruptura não foi determinada pelo bloco.

Realizando os mesmos cálculos para a argamassa, nota-se que, com 52 minutos de incêndio, ela suportaria uma força aproximada de $72,6 \mathrm{kN}$ de compressão. Depois de 73 minutos de incêndio sua resistência à compressão cairia para $48,0 \mathrm{kN}$. Como existe o efeito do confinamento, nesse último instante o processamento ainda é possível com o carregamento de $53,0 \mathrm{kN}$. Com uma maior deterioração térmica do material, este suportará uma força inferior a $53,0 \mathrm{kN}$, gerando ruptura teórica e o fim do processamento. Assim, considerou-se que a ruptura do prisma ocorreu no tempo final das simulações, para o caso de carregamento fixo durante o incêndio.

A Figura 81 apresenta a distribuição de tensões principais máximas e mínimas para os carregamentos de 20 e $35 \% \mathrm{f}_{\mathrm{pk}}$ nos instantes considerados de ruptura, com escala de deformação de 50 para melhor visualização dos resultados. 
Figura 81 - Tensões máximas e mínimas principais nos instantes considerados de ruptura $(\mathrm{Pa})$
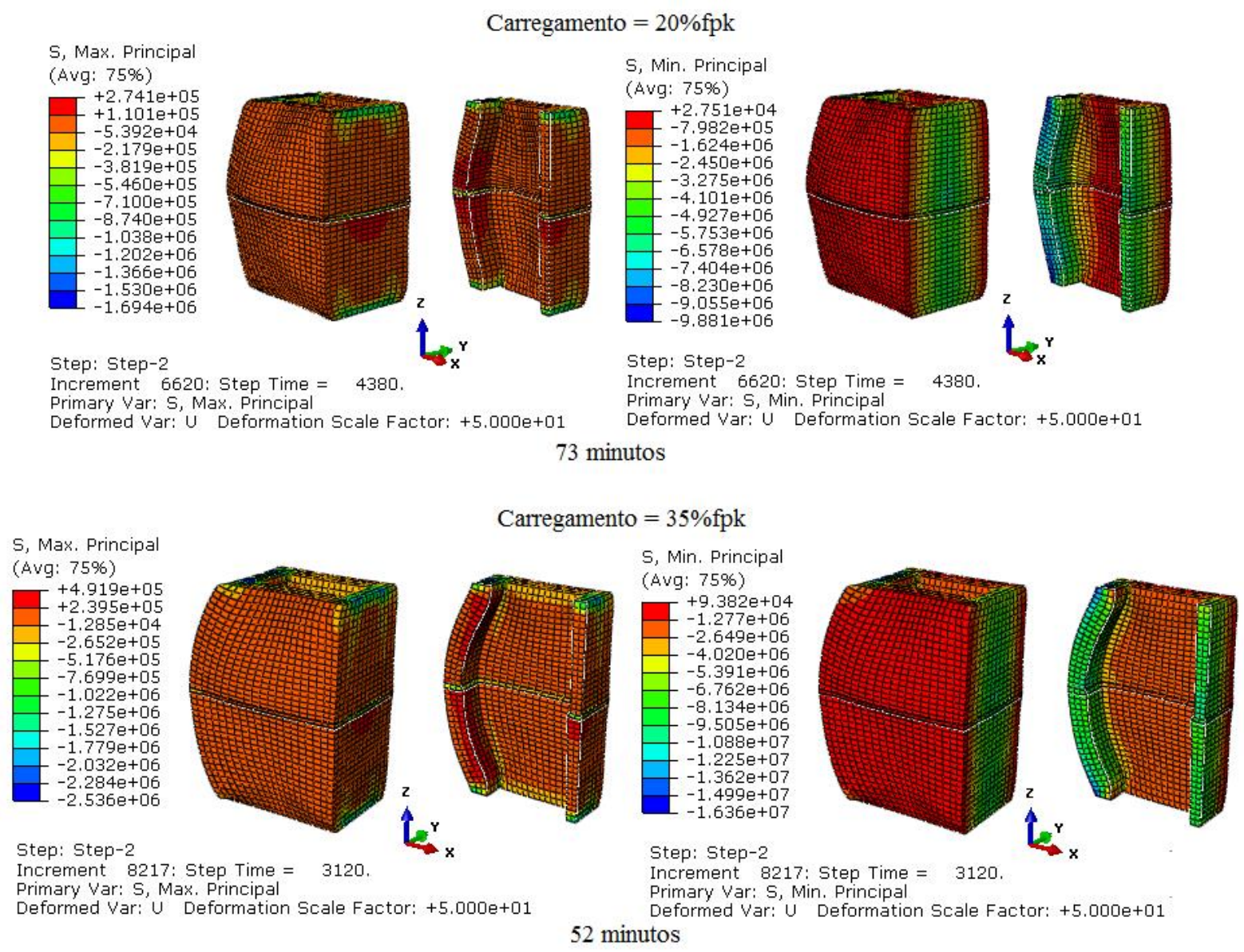

Fonte: Autora (2018)

Observa-se que as faces mais próximas do fogo estão deterioradas, não resistindo a praticamente nenhuma tensão. A argamassa se encontra mais deformada que os blocos para os dois casos, o que é o esperado.

Neste caso de incêndio em duas faces, foi feita também a verificação com restrição vertical. Para isso, aplicaram-se os carregamentos por meio de um passo inicial e no passo de incêndio restringiu-se o deslocamento na direção $\mathrm{Z}$ da placa superior. Assim, a deformação axial do prisma se deve apenas aos carregamentos iniciais e com a restrição vertical têm-se incrementos de força à medida que o prisma tende a aumentar as suas dimensões geométricas por acréscimo de temperatura. A variação da força considerando-se o prisma completo, ou seja, carregamento duplicado, pode ser observada na Figura 82. 
Figura 82 - Variação da força para o prisma com restrição vertical e duas faces expostas ao incêndio

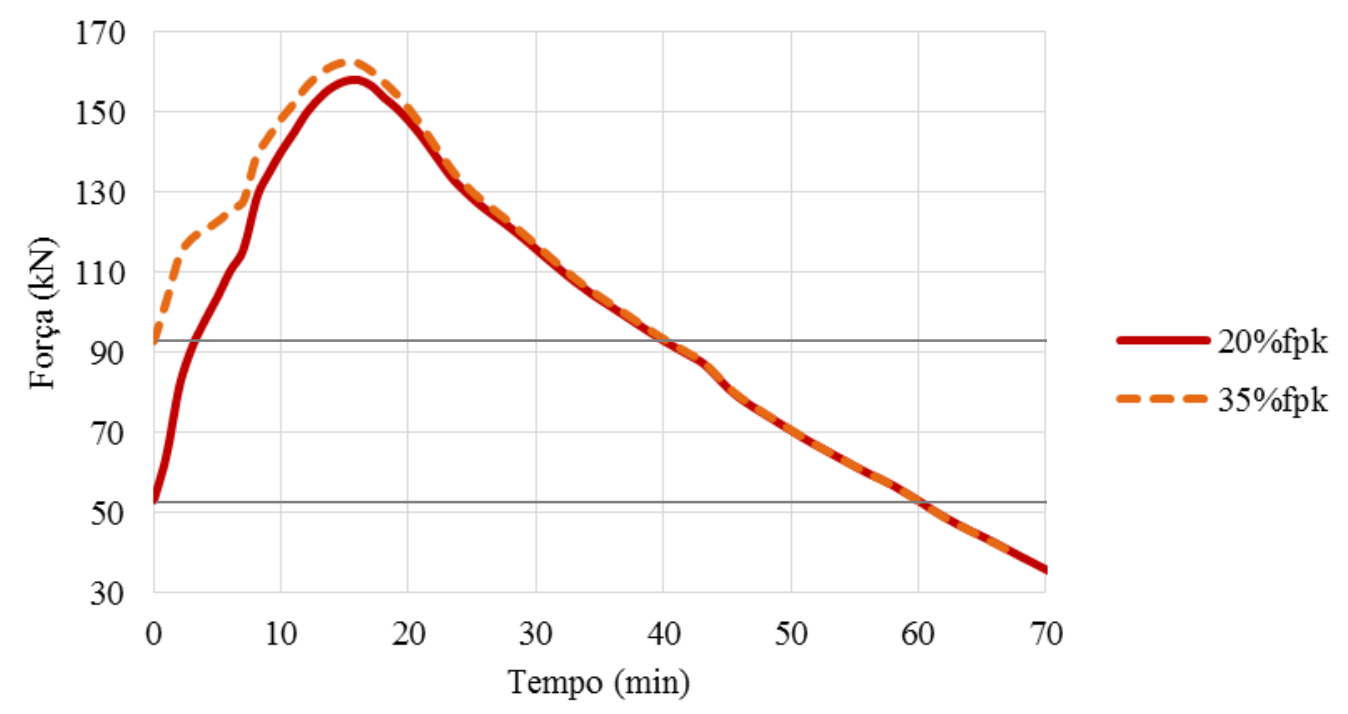

Fonte: Autora (2018)

Com $20 \% \mathrm{f}_{\mathrm{pk}}$ o processamento ocorreu durante 180 minutos de incêndio, tempo total da simulação térmica, até a força ficar próxima de zero. Já com $35 \% \mathrm{f}_{\mathrm{pk}}$ o processamento foi interrompido após 67 minutos de incêndio com força de aproximadamente $41 \mathrm{kN}$. Entretanto, observa-se que para os dois níveis de carregamento o decréscimo de força após o pico, de aproximadamente $160 \mathrm{kN}$, segue praticamente a mesma taxa.

A falha do critério de resistência mecânica ocorre quando em determinado tempo de incêndio o elemento não suporta mais o carregamento para o qual foi projetado. Assim, neste caso considerou-se a ruptura no instante em que a força atinge o valor inicialmente aplicado, conforme feito em Neves (1995). Então, o prisma com restrição vertical resistiu a 60 e 40 minutos de incêndio com carregamentos de 20 e $35 \% \mathrm{f}_{\mathrm{pk}}$, respectivamente. Na Figura 83 estão dispostas as distribuições de tensões principais máximas e mínimas nos instantes considerados de ruptura com escala de deformação 50 . 
Figura 83 - Tensões máximas e mínimas principais do prisma com restrição vertical nos instantes considerados de ruptura $(\mathrm{Pa})$

S, Max. Principal (Avg: $75 \%$ )

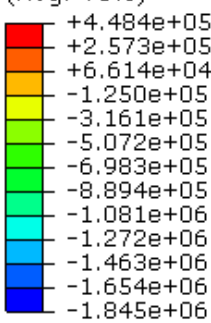

Step: Step-2

Increment 6277: Step Time $=3602$

Primary Var: S, Max. Principal

Deformed Var: U Deformation Scale Factor: +5.000e+01

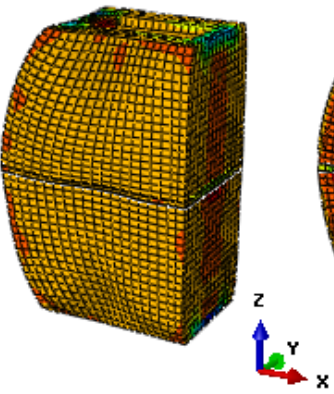

Carregamento $=20 \% \mathrm{fpk}$

S, Min. Principal (Avg: $75 \%$ )
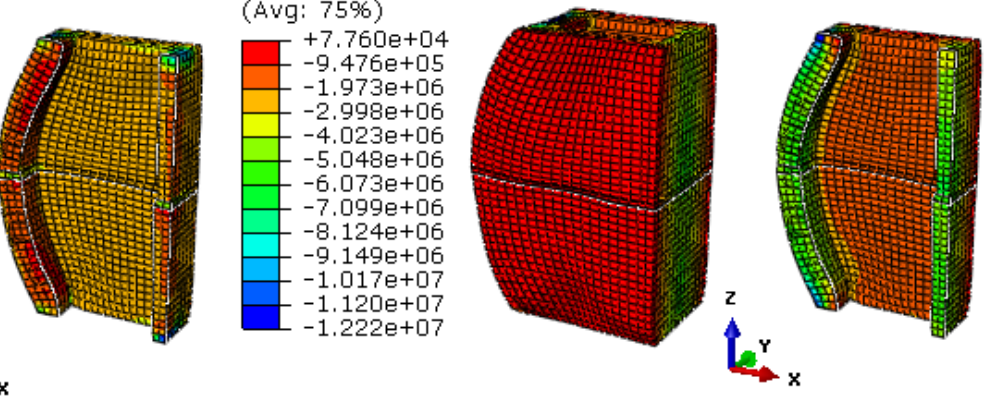

Step: Step-2

Increment 6277: Step Time $=3602$

Primary Var: S, Min. Principal

Deformed Var: U Deformation Scale Factor: $+5.000 e+01$

60 minutos

S, Max. Principa (Avg: 75\%)
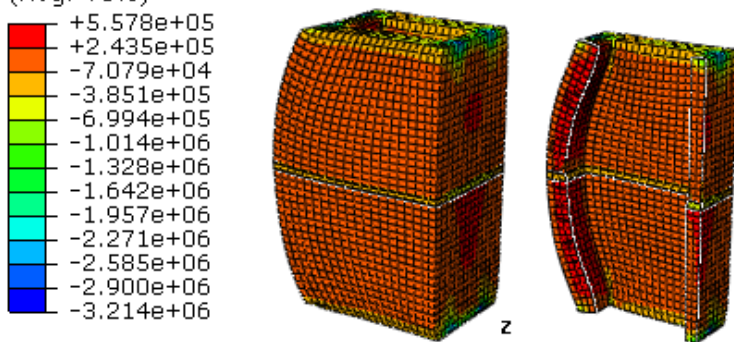

Carrgamento $=35 \% \mathrm{fpk}$

Step: Step-2
Increment 2813: Step Time $=2400$.

Primary Var: S, Max. Principal

Deformed Var: U Deformation Scale Factor: +5.000e+01

S, Min. Principal (Avg: $75 \%$ )

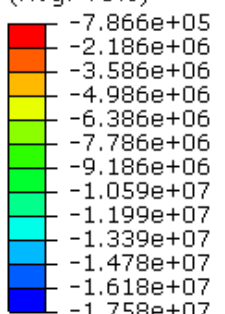

$-1.758++07$

Step: Step-2

Increment 2813: Step Time $=2400$.
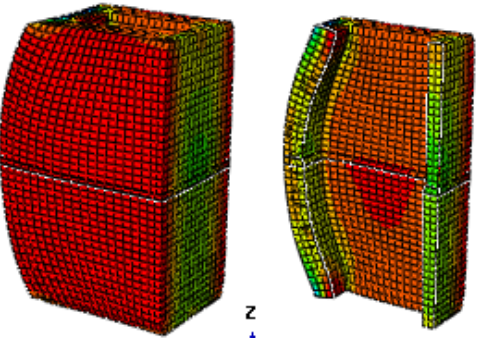

Primary Var: $S$, Min. Principal

Deformed Var: U Deformation Scale Factor: $+5.000 e+01$

40 minutos

Fonte: Autora (2018)

\subsection{PRISMA SEM REVESTIMENTO E UMA FACE EXPOSTA AO FOGO}

Para o prisma carregado e com uma face exposta ao fogo, inicialmente foram verificados os casos de carregamento constante com e sem restrição rotacional. Em seguida verificou-se a aplicação de restrição de deslocamento vertical após a aplicação do carregamento inicial. 


\subsubsection{Resultados e comparações}

\subsubsection{Carregamento constante com e sem restrição rotacional}

Como inicialmente o carregamento foi mantido constante durante as simulações de incêndio, analisaram-se os resultados de deformação axial do prisma. Calculou-se a deformação axial em três diferentes pontos do prisma: na face exposta ao incêndio, no centro do prisma e na face exposta à temperatura ambiente. A modelagem com carregamento fixo de $20 \% \mathrm{f}_{\mathrm{pk}}$ e restrição rotacional foi processada até o tempo final da análise térmica de cinco horas. Assim, por meio do software, não foi indicada a ruptura para esse nível de carregamento. Já com $35 \% \mathrm{f}_{\mathrm{pk}}$ o processamento foi interrompido, indicando a ruptura para um tempo de 208 minutos de incêndio. Na Figura 84 está ilustrada a deformação axial do prisma com carregamento fixo e restrição rotacional para os três pontos e dois níveis de carregamento.

Figura 84 - Deformação axial do prisma com carregamento fixo e restrição rotacional

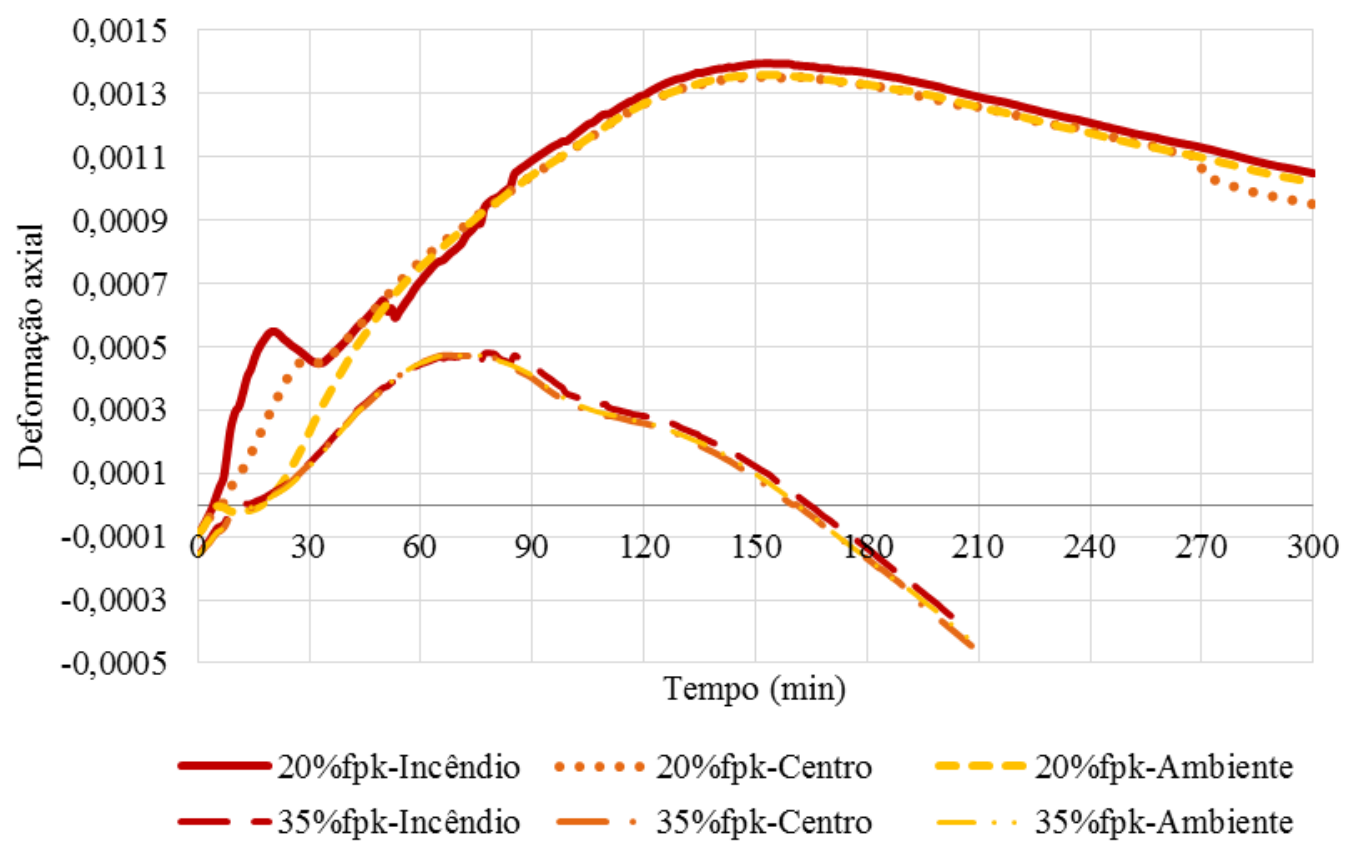

Fonte: Autora (2018)

Inicialmente os prismas carregados com 20 e $35 \% f_{\text {pk }}$ possuem deformação axial de 9 x $10^{-5}$ e $1,6 \times 10^{-4}$. Observa-se que antes de 30 minutos a face exposta ao incêndio se expande mais que o centro e a face exposta ao ambiente, como esperado. Em seguida, devido à 
restrição rotacional, para o mesmo carregamento, os valores de deformação axial ficam próximos.

Mediu-se o deslocamento lateral do centro do prisma, posição do plano de simetria, nas faces expostas ao incêndio e ao ambiente, na direção do eixo Y. Os valores negativos significam que estão no sentido contrário ao eixo. Essas medidas de deslocamento são mostradas na Figura 85.

Figura 85 - Deslocamento lateral do prisma sem revestimento com uma face exposta ao incêndio carregamento fixo e restrição rotacional

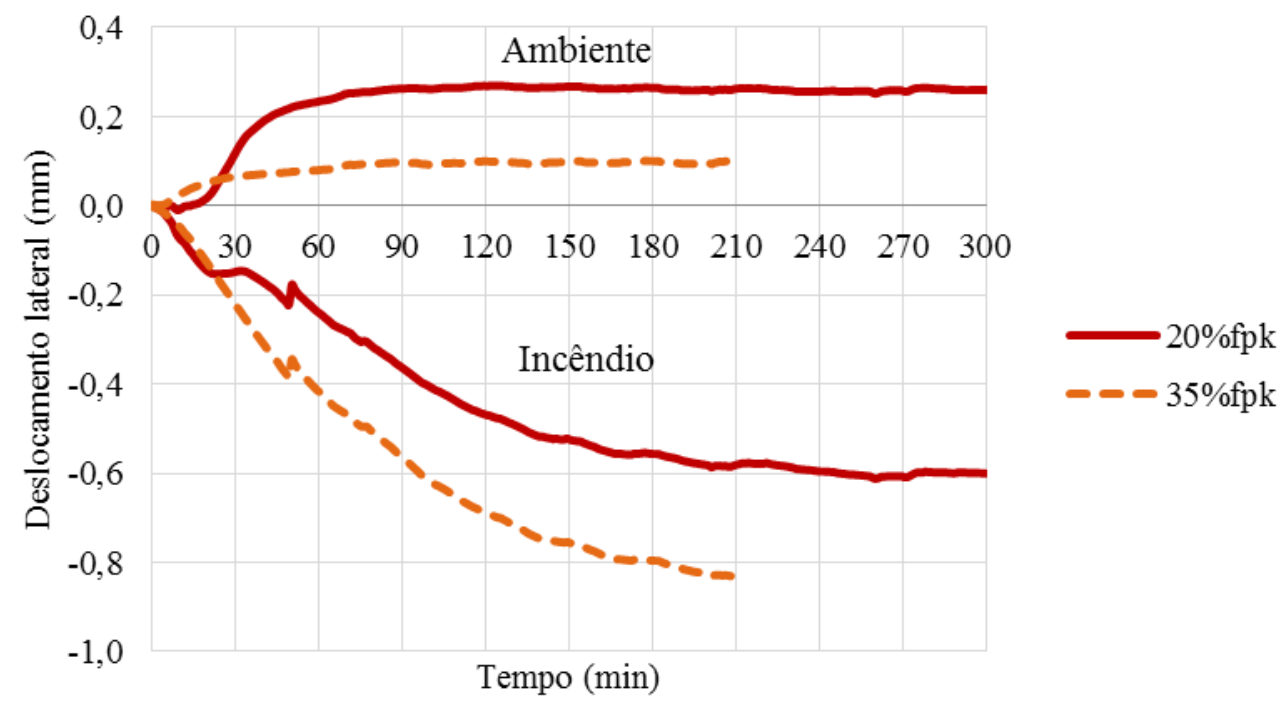

Fonte: Autora (2018)

Observa-se na Figura 85 que para um nível de carregamento maior, mais elevado é o deslocamento lateral dos pontos mais próximos à face exposta ao fogo, sendo maior o efeito do encurvamento térmico. Na Figura 86 são apresentados os campos térmicos no bloco e na argamassa para o tempo de 208 minutos, instante considerado de ruptura para o carregamento de $35 \% \mathrm{f}_{\mathrm{pk}}$. 
Figura 86 - Campos térmicos no instante considerado de ruptura para o carregamento de $35 \% \mathrm{f}_{\mathrm{pk}}\left({ }^{\circ} \mathrm{C}\right)$

Bloco

NT11

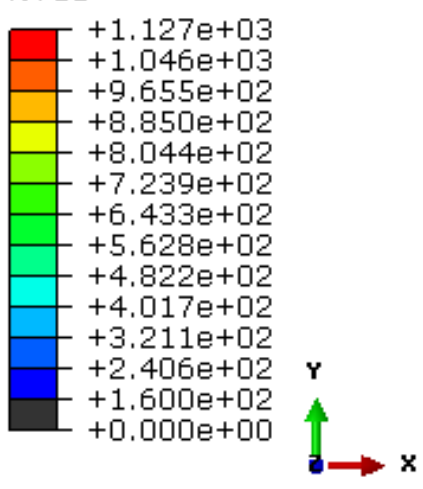

Step: Step-2

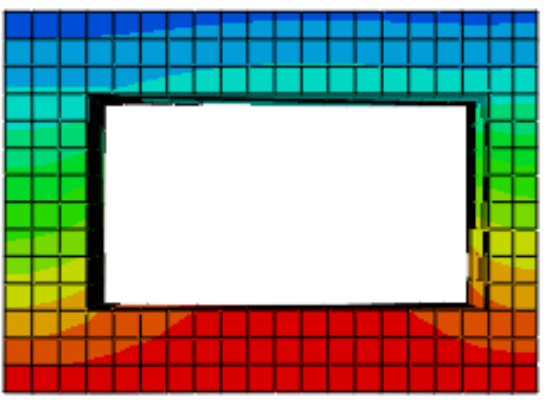

208 minutos

Increment 8687: Step Time $=1.2483 \mathrm{E}+04$

Primary Var: NT11

Deformed Var: U Deformation Scale Factor: +1.000 +00

Fonte: Autora (2018)

Observam-se temperaturas da ordem de $1000^{\circ} \mathrm{C}$ na Figura 86, e conforme as curvas tensão-deformação apresentadas nas Figuras 72 e 73, os materiais não apresentam quase nenhuma resistência para essa temperatura. As tensões principais máximas e mínimas desenvolvidas no prisma para o tempo de 208 minutos e o carregamento de $35 \% \mathrm{f}_{\mathrm{pk}}$ estão presentes na Figura 87 com escala de deformação de 20. 
Figura 87 - Tensões máximas e mínimas principais desenvolvidas no prisma para o carregamento de $35 \% \mathrm{f}_{\mathrm{pk}}$ e restrição rotacional no instante de ruptura $(\mathrm{Pa})$

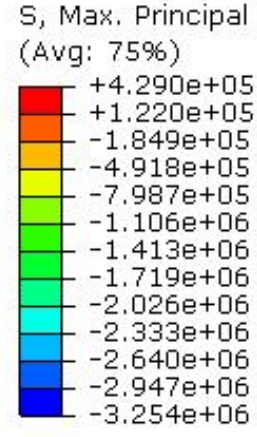

Step: Step-2

Increment $8687:$ Step Time $=1.2483 \mathrm{E}+04$ Primary Var: S, Max. Principal

Deformed Var: $U$ Deformation Scale Factor: +2.000e+01

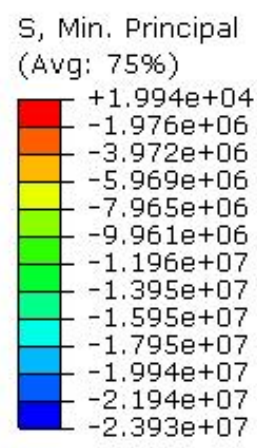

Step: Step-2

Increment 8687: Step Time $=1.2483 \mathrm{E}+04$

Primary Var: S, Min. Principal

Deformed Var: $U$ Deformation Scale Factor: $+2.000 e+01$

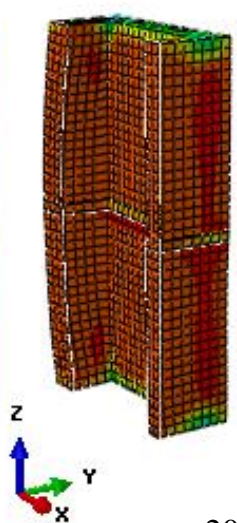

208 minutos
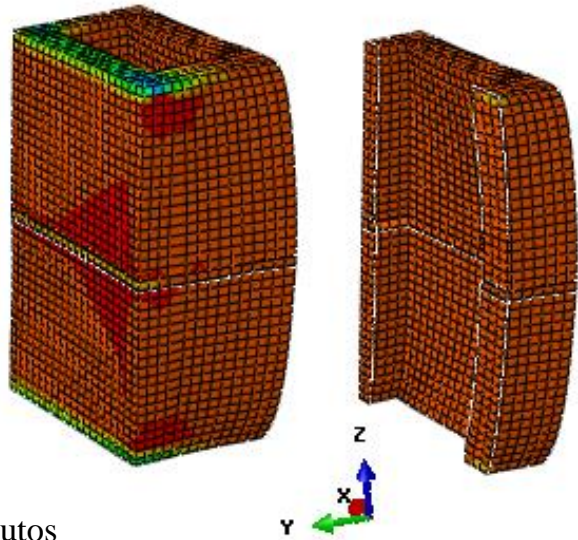
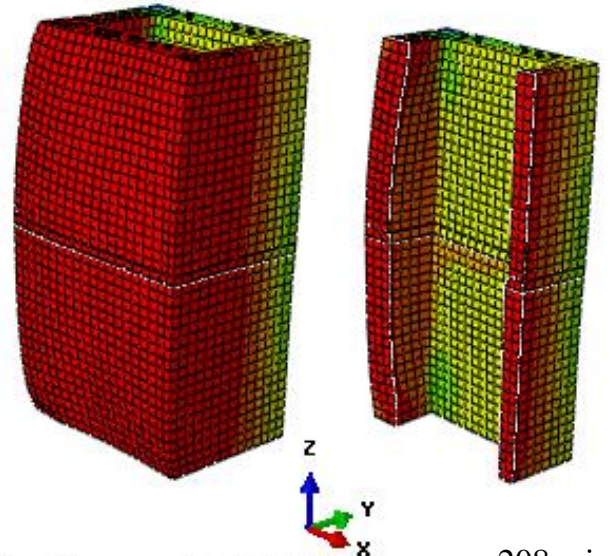

208 minutos
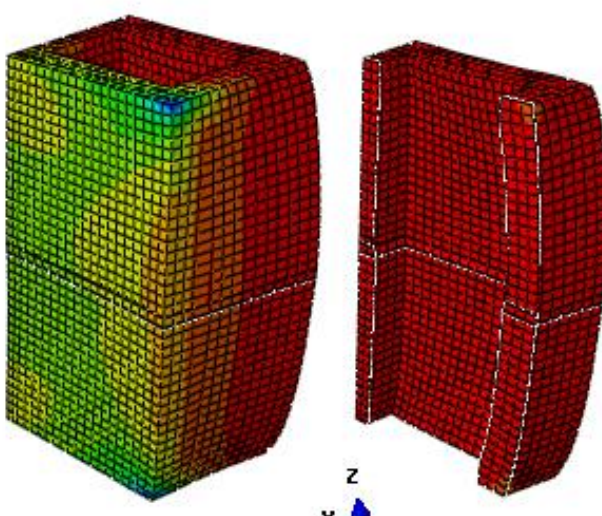

Fonte: Autora (2018)

Observa-se o encurvamento do prisma no sentido do fogo, conforme indicado pelo deslocamento lateral apresentado na Figura 85. Além disso, nota-se que o material mais próximo do fogo apresenta tensões praticamente nulas indicando que ocorreu a sua deterioração térmica.

Para o caso de carregamento constante e sem restrição rotacional da placa de compressão, também foi analisada a deformação axial do prisma na face exposta ao incêndio, no centro do prisma e na face exposta ao ambiente. Na Figura 88 é apresentada a deformação axial para esses pontos com dois níveis de carregamento. 
Figura 88 - Deformação axial do prisma com carregamento fixo e sem restrição rotacional

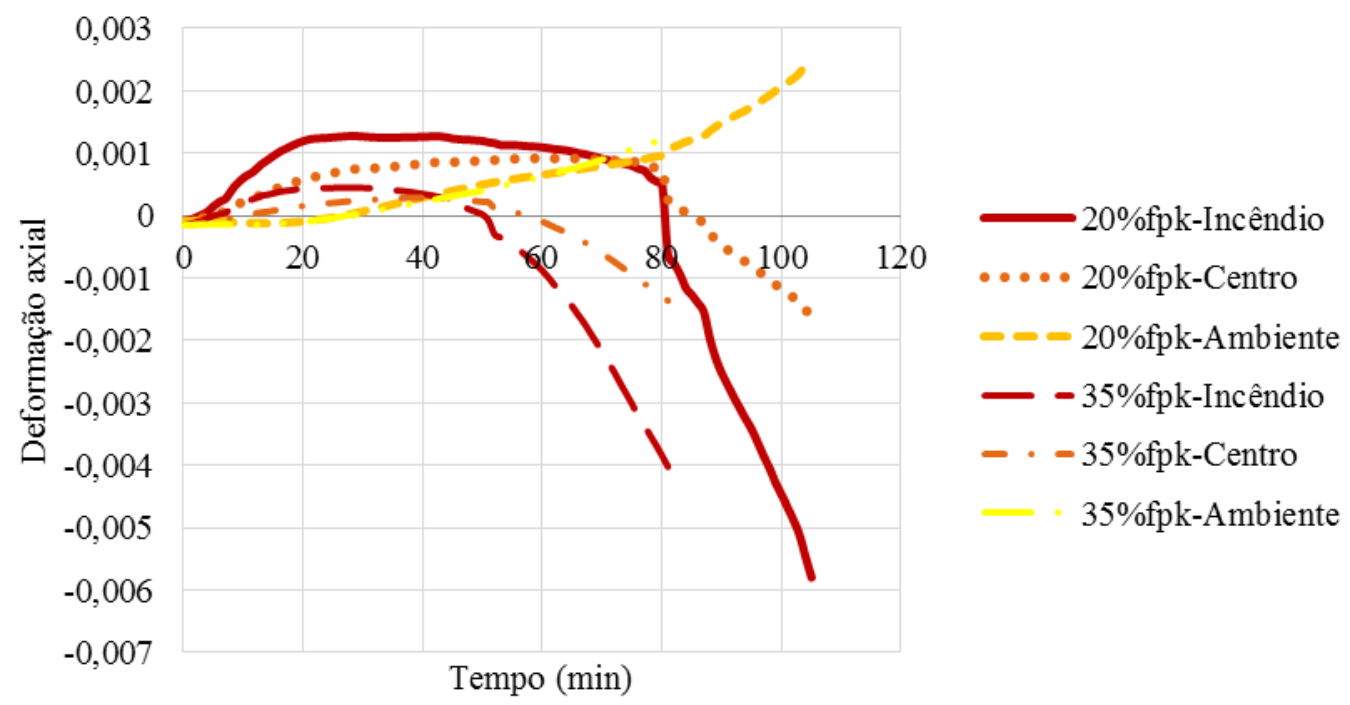

Fonte: Autora (2018)

Observa-se que inicialmente ocorreu a expansão da face exposta ao incêndio, enquanto aquela exposta ao ambiente possuía deformação constante. Após determinado intervalo de incêndio para cada carregamento ocorre uma inversão de tendências. A face exposta ao ambiente passou a se dilatar enquanto ocorreu a contração daquela exposta ao incêndio. Para os dois níveis de carregamento o processamento foi interrompido em tempos consideravelmente inferiores ao caso de restrição rotacional, 105 e 81 minutos para os carregamentos de 20 e $35 \% \mathrm{f}_{\mathrm{pk}}$, respectivamente.

A Figura 89 apresenta as tensões principais máximas e mínimas para o carregamento de $35 \% \mathrm{f}_{\mathrm{pk}}$ e sem restrição rotacional no instante de 81 minutos, tempo final de processamento ou instantes considerados de ruptura, com escala de deformação de 20. 
Figura 89 - Tensões máximas e mínimas principais desenvolvidas no prisma para o carregamento de $35 \% \mathrm{f}_{\mathrm{pk}}$ e sem restrição rotacional no instante final de processamento (Pa)

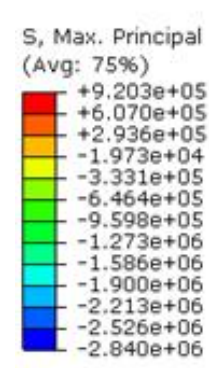

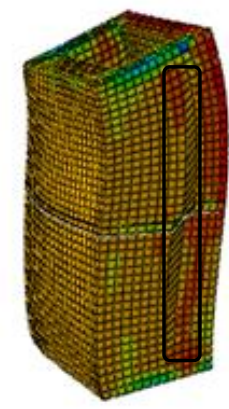

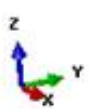

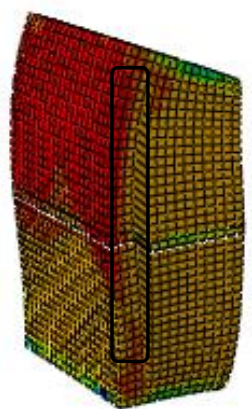

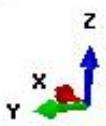

Step: Step-2

Increment 5753: Step Time $=4860$ Primary Var: S, Max. Principal Deformed Var: $U$ Deformation Scale Factor: $+2,000 e+01$
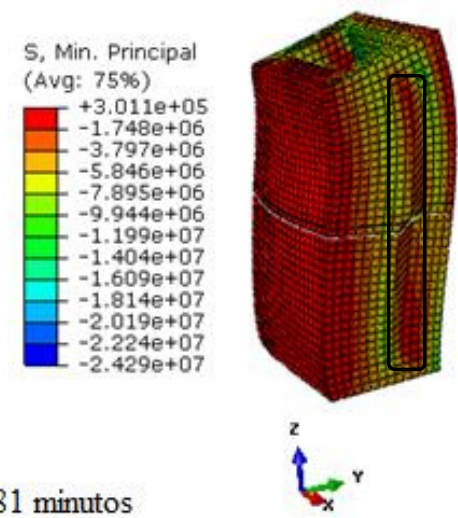

81 minutos

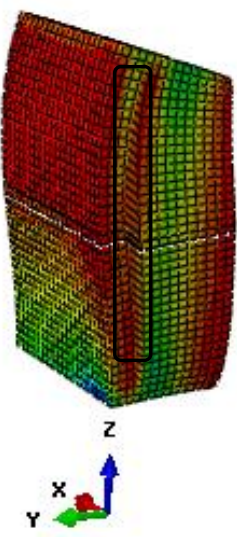

Step: Step-2

Increment 5753: Step Time $=4860$.

Primary Var: S, Min. Principal

Deformed Var: U Deformation Scale Factor: $+2.000 e+01$

Fonte: Autora (2018)

É possível notar na Figura 89 a rotação do topo do prisma, a qual provoca a rotação da placa de compressão. Além disso, percebe-se que a região do prisma exposta ao fogo está deteriorada. Enquanto a região interna do prisma está suportando tensões de compressão, a região externa, com face exposta ao ambiente, está sujeita a tensões de tração. A ruptura do prisma ocorre entre as regiões tracionada e comprimida, nas áreas destacadas da Figura 89.

\subsubsection{Restrição de deslocamento vertical com e sem restrição rotacional}

Como no primeiro caso, carregamento constante e restrição rotacional, atingiu-se a ruptura apenas do prisma carregado com $35 \% \mathrm{f}_{\mathrm{pk}}$, para possibilitar comparações, são apresentados os resultados apenas deste nível de carregamento.

Conforme feito no caso de incêndio em duas faces, com a imposição de restrição vertical após a aplicação do carregamento, analisaram-se os incrementos de força. Na Figura 90 está ilustrada a variação de força para estes dois casos. 
Figura 90 - Variação da força para o prisma com restrição vertical e uma face exposta ao incêndio

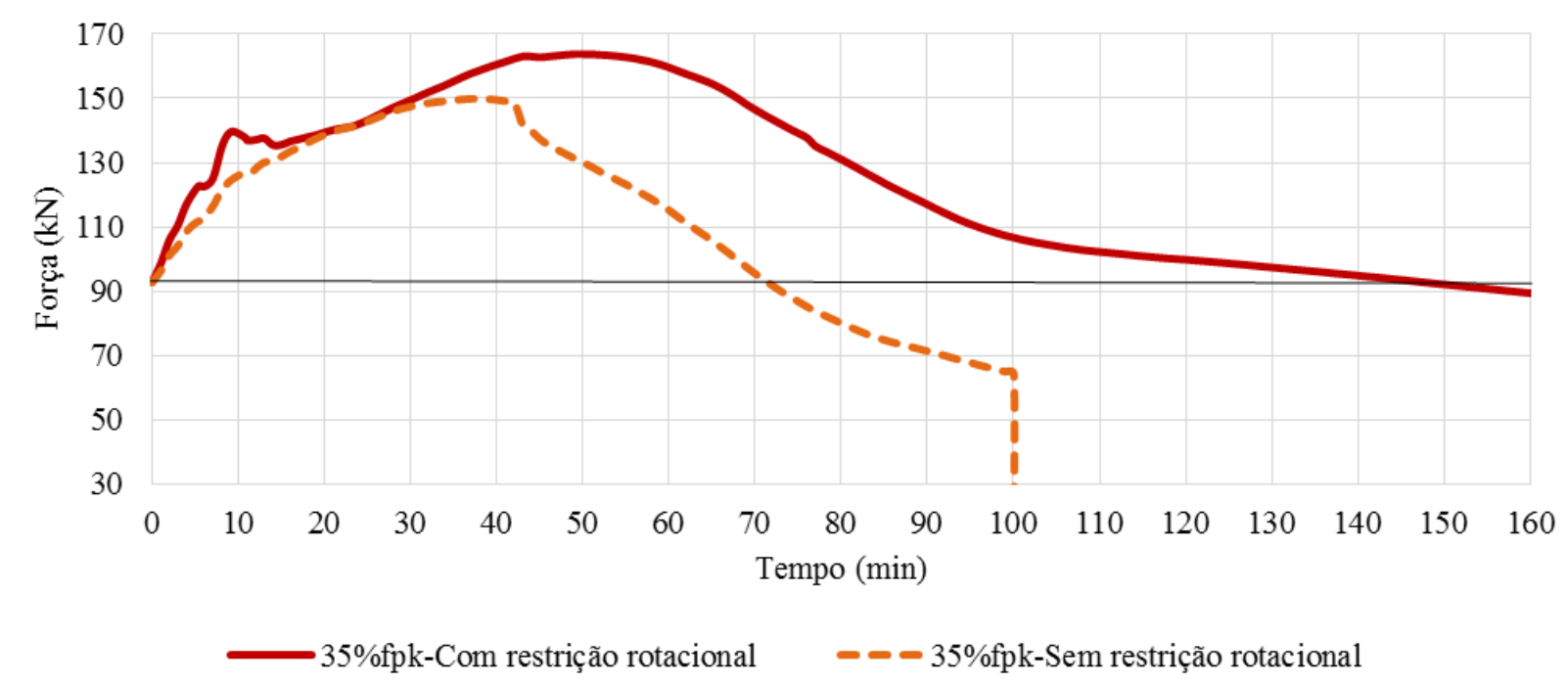

Fonte: Autora (2018)

Nota-se na Figura 90 que a força máxima atingida para o caso de restrição rotacional é de aproximadamente $160 \mathrm{kN}$, mesmo valor apresentado na Figura 82 para o caso de duas faces expostas ao incêndio. A força inicialmente aplicada no prisma é atingida em 148 e 72 minutos para os casos com e sem restrição rotacional, respectivamente.

A força máxima atingida sem a restrição rotacional foi inferior a $160 \mathrm{kN}$ pois, neste caso, o giro do topo do prisma e consequente giro da placa de compressão causa a decomposição da força resultante, que inicialmente era paralela ao eixo $\mathrm{Z}$, em uma componente em Y.

Com a restrição rotacional o processamento foi completo, durante 300 minutos de incêndio. Já para o caso sem restrição rotacional ocorreu uma queda brusca da força aos 100 minutos seguida da interrupção do processamento. A Figura 91 apresenta as tensões principais mínimas desenvolvidas no prisma sem restrição rotacional aos 100 minutos com escala de deformação de 1 . 
Figura 91 - Tensões principais mínimas desenvolvidas no prisma sem restrição rotacional no instante final de processamento

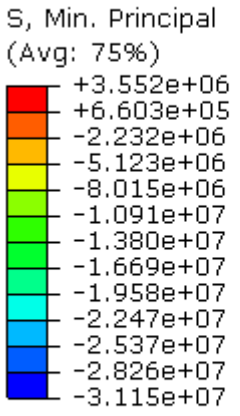

Step: Step-2

Increment 20355: Step Time $=6005$.

Primary Var: S, Min. Principal

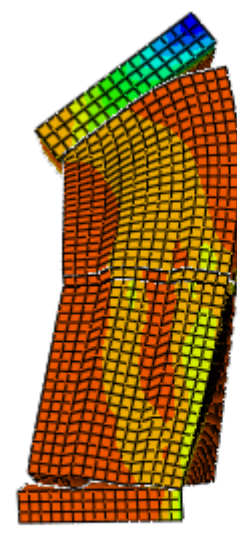

Deformed Var: U Deformation Scale Factor: +1.000e+00
S, Min. Principal (Avg: 75\%)
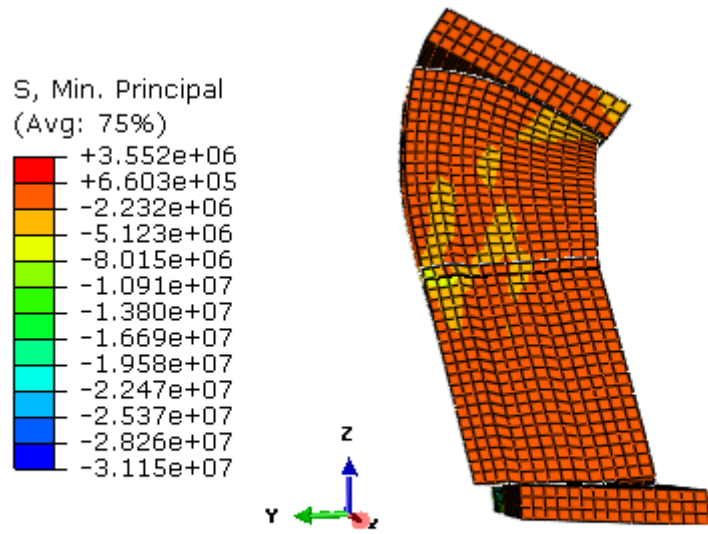

Step: Step-2

Increment 20355: Step Time $=6005$

Primary Var: 5 , Min. Principal

Deformed Var: U Deformation Scale Factor: +1.000e+00

Fonte: Autora (2018)

É possível notar a inclinação e deslocamento da base do prisma em relação à placa inferior, indicando que a queda brusca de força aos 100 minutos ocorre devido ao tombamento/escorregamento do prisma.

As tensões máximas e mínimas principais desenvolvidas no prisma nos instantes em que se atinge a força aplicada inicialmente estão ilustradas na Figura 92 com escala de deformação de 20 . 
Figura 92 - Tensões máximas e mínimas principais desenvolvidas no prisma com e sem restrição rotacional e restrição de deslocamento vertical carregado inicialmente com $35 \% \mathrm{f}_{\mathrm{pk}}$

(Pa)
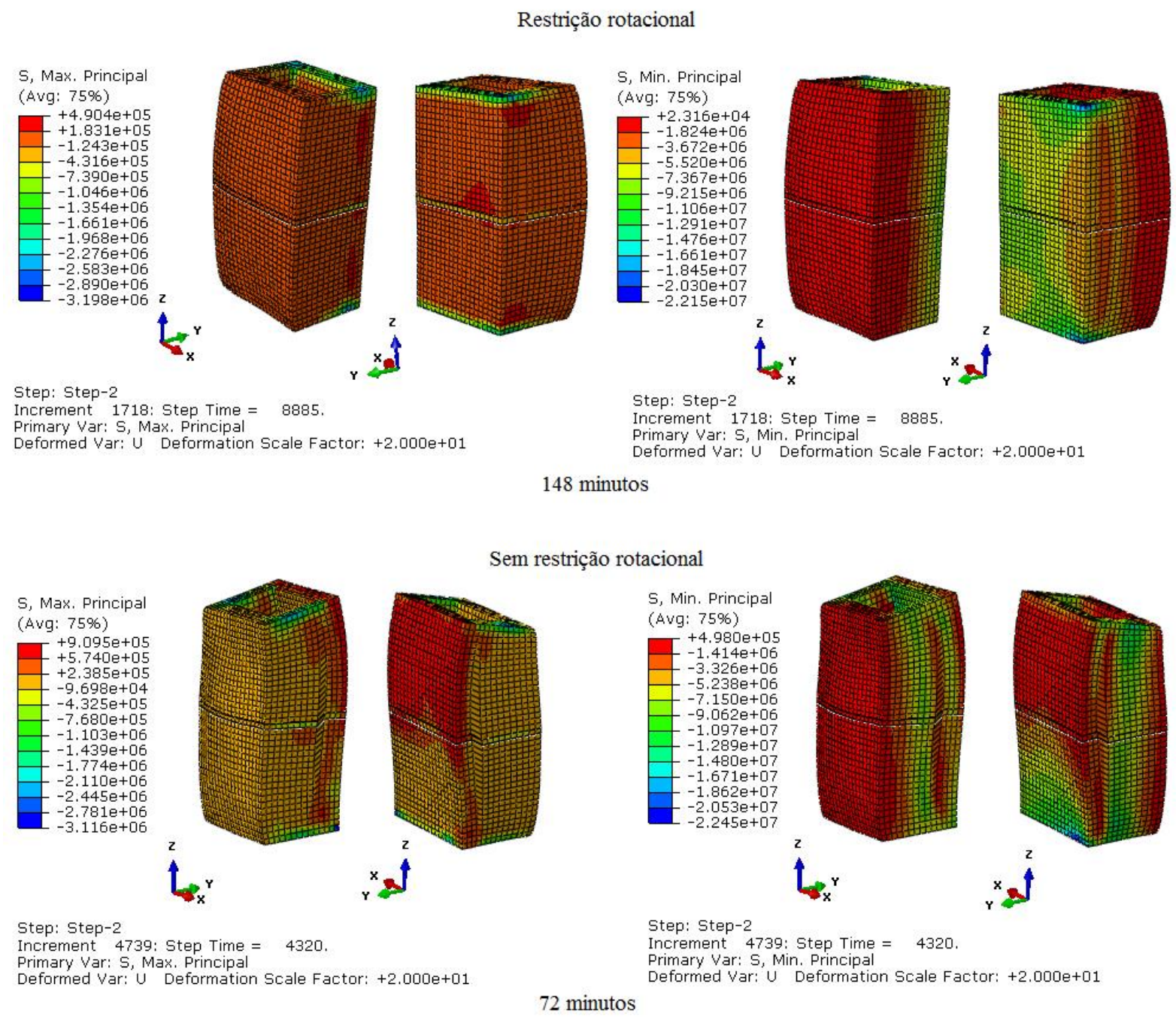

Fonte: Autora (2018)

Para o caso sem restrição rotacional é possível notar uma inclinação da parte superior do prisma. A falta de restrição rotacional gera uma distribuição de tensões diferentes daquela restrita. No caso sem restrição rotacional, surgem tensões de tração na face exposta ao ambiente, como pôde ser observado na Figura 89. 


\section{DISCUSSÃO DOS RESULTADOS}

A simulação térmica da alvenaria cerâmica foi feita sem o uso da interação fluidoestrutura e sem a representação da convecção e da radiação nas cavidades, seguindo as modelagens feitas por Rosemann (2011). Para compensar isto, a condutividade térmica do material cerâmico foi aumentada. Neste caso, destaca-se a dificuldade em criar a massa de ar para os pequenos vazados, justificando o não emprego da interação fluido-estrutura para o bloco cerâmico. Como a argamassa não teve as suas propriedades alteradas, após a validação das mesmas foi possível utilizá-las nos prismas compostos por blocos de concreto.

A modelagem térmica dos prismas compostos por blocos de concreto foi feita por meio da interação fluido-estrutura para a representação do ar nas cavidades. Como neste caso não se representou a radiação, a condutividade térmica do ar foi aumentada.

Para os dois casos, a evolução de temperatura nas faces não expostas ao fogo ficou bem representada. Os resultados numéricos de elevação de temperatura nas faces não expostas da alvenaria cerâmica sem e com revestimento foram comparados com experimentos feitos por Rosemann (2011).

Conforme a ABNT NBR 6136:2016 a espessura média das paredes de blocos de classe $\mathrm{C}$ é um pouco inferior àqueles pertencentes às classes $\mathrm{A}$ e B. Entretanto, utilizando as mesmas dimensões e propriedades térmicas dos materiais, foi possível representar a elevação de temperatura na face não exposta ao fogo de uma parede constituída por blocos de classe $\mathrm{C}$ e o grau corta-fogo de outra constituída por blocos de classe A. Além disso, em Bloco Brasil (2016) são apresentados resultados finais de ensaios de resistência ao fogo de duas paredes, sendo uma formada por blocos de classe B e outra por blocos de classe C, nos quais o critério de isolamento térmico falhou em tempos similares para ambas as paredes. Assim, essa diferença de espessura das paredes do bloco não foi significativa para o critério de isolamento térmico.

Os resultados do prisma composto por blocos de concreto com revestimento em uma face foram comparados com ensaio obtido junto à empresa Glasser. O prisma composto por blocos de concreto e sem revestimento apresentou o mesmo grau de corta-fogo que uma parede com função portante apresentada em Chichierchio (1990). Na Tabela 20 consta o tempo em que se atingiu a variação de temperatura limite do critério de isolamento térmico em cada simulação. 
Tabela 20 - Resumo das simulações térmicas

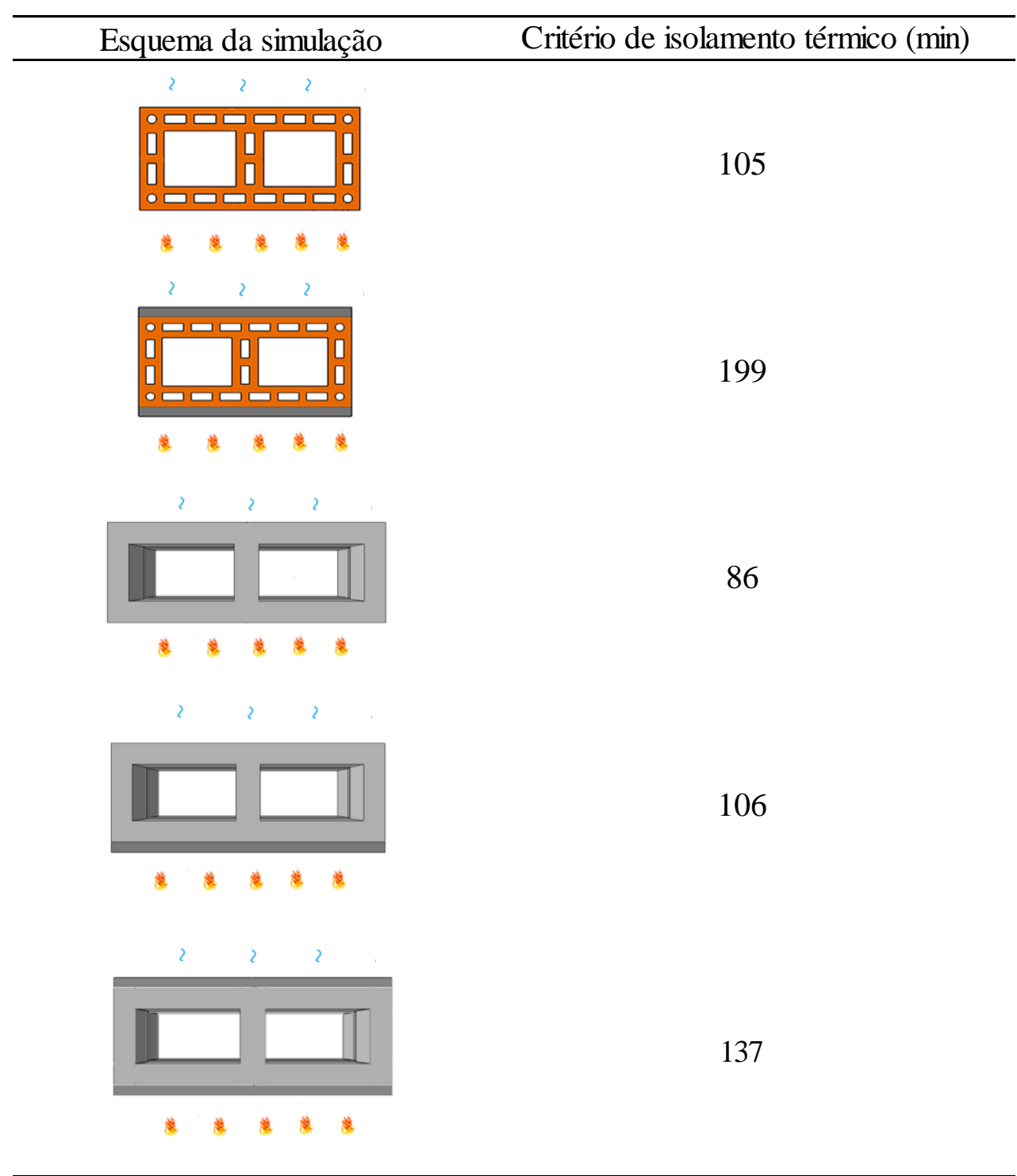

Fonte: Autora (2018)

Observa-se que o bloco cerâmico possui teoricamente uma maior capacidade de isolamento térmico que o bloco de concreto. Nota-se, também, uma considerável influência favorável ao isolamento térmico quando se tem a aplicação de revestimento em argamassa com espessura de $1,5 \mathrm{~cm}$ em ambas as faces dos elementos.

O critério de estanqueidade não foi avaliado nas simulações. Nos trabalhos apresentados na revisão bibliográfica sobre alvenaria em situação de incêndio em que foram avaliados os três critérios, as paredes se mantiveram estanques até a ruptura. Além disso, em Chichierchio (1990) e Bloco Brasil (2016) são apresentados resultados finais de ensaios de resistência ao fogo de paredes carregadas e em situação de incêndio, nos quais se consideram a perda de estanqueidade no mesmo instante da perda de resistência mecânica. 
As condições de contorno de um elemento estrutural dependem das definições em projeto e execução da construção. Por isso, nas simulações termomecânicas foram analisados casos sem restrição de deslocamento vertical (S.R.D.V.) ou carregamento constante, com restrição de deslocamento vertical (C.R.D.V.) após a aplicação do carregamento, com e sem restrição rotacional, (C.R.R.) e (S.R.R.), respectivamente. Na Tabela 21 encontram-se os tempos de ruptura ou finais de processamento para cada caso analisado no presente trabalho.

Tabela 21 - Resumo das simulações termomecânicas

\begin{tabular}{|c|c|c|c|c|c|c|c|c|}
\hline \multicolumn{4}{|c|}{ Esquema da simulação } & Carregamento & \multicolumn{2}{|c|}{ S.R.D.V. (min) } & \multicolumn{2}{|c|}{ C.R.D.V. (min) } \\
\hline s & s & s & 2 & $20 \%$ fpk & \multicolumn{2}{|c|}{73} & \multicolumn{2}{|c|}{60} \\
\hline 28 & * & , & 8 & $35 \% \mathrm{fpk}$ & \multicolumn{2}{|c|}{52} & \multicolumn{2}{|c|}{40} \\
\hline & & & & & C.R.R. & S.R.R. & C.R.R. & S.R.R. \\
\hline 2 & 2 & & 2 & $20 \% \mathrm{fpk}$ & 300 & 105 & - & - \\
\hline s & $*$ & s & s & $35 \% \mathrm{fpk}$ & 208 & 81 & 148 & 72 \\
\hline
\end{tabular}

Fonte: Autora (2018)

Observa-se que o impedimento de deslocamento vertical e/ou aplicação de um maior valor de carregamento faz com que o elemento resista mecanicamente a um tempo inferior de incêndio, como esperado. Nota-se também através da Tabela 21 que o incêndio nas duas faces foi mais prejudicial ao prisma.

Para os casos com restrição rotacional um momento adicional é gerado que deveria resultar em uma maior deterioração dos materiais no lado exposto ao fogo, e consequente ruptura em tempo inferior ao caso sem restrição rotacional. Entretanto aconteceu o contrário. Sem a restrição rotacional surgem tensões de tração na face não exposta ao incêndio, tendo então um modo de ruptura diferente e em tempo inferior aos casos com restrição rotacional.

Considerando-se o caso de carregamento constante conforme especifica a ABNT NBR 5628:2001 e restrição rotacional conforme indicado em Nadjai et al. (2003) e Russo e Sciarretta (2013), a aplicação do que seria o "carregamento em serviço do prisma" com o valor de $35 \% \mathrm{f}_{\mathrm{pk}}$ causou a ruptura do prisma em 208 minutos ou $3 \mathrm{~h} 28 \mathrm{~min}$ para uma face 
exposta ao incêndio. Conforme Chichierchio (1990) uma parede com função portante constituída por blocos da antiga Tecprem manteve-se estável ao fogo durante 4 horas.

De acordo com a ABNT NBR 5628:2001 a resistência mecânica corresponde a 80\% do tempo em que o elemento esteve carregado e em situação de incêndio, até a sua ruína. Então o prisma cuja ruptura se deu em 208 minutos possui resistência mecânica em situação de incêndio de 166 minutos, resultado inferior ao apresentado em Chichierchio (1990). Ainda assim, o critério de isolamento térmico foi o primeiro a falhar com 86 minutos para o prisma sem revestimento. Considerando que o prisma se mantenha estanque até a sua ruptura, conforme visto na revisão bibliográfica, este possuirá grau corta-fogo CF60.

Para o caso do prisma com revestimento nas duas faces, a perda de isolamento térmico se deu aos 137 minutos. Se este possuir resistência mecânica de 166 minutos e mantiver-se estanque até a sua ruptura, o prisma com revestimento nas duas faces possuirá grau corta-fogo CF120. Provavelmente, o mesmo possuirá resistência mecânica superior a 166 minutos devido à menor deterioração térmica dos materiais. 


\section{CONCLUSÕES}

Inicialmente, em temperatura ambiente foi simulado o comportamento do bloco sujeito à compressão. As propriedades necessárias ao modelo de plasticidade do software que não haviam sido obtidas por Oliveira (2014) foram calibradas para que se obtivesse o melhor ajuste possível entre os resultados experimentais e numéricos. Obteve-se um adequado ajuste entre os resultados numérico e experimental de tensão-deformação até a tensão máxima de compressão.

Com as propriedades do bloco ajustadas, simulou-se o comportamento do prisma constituído por três blocos de concreto e argamassamento parcial sujeito à compressão e em temperatura ambiente. Da mesma forma, as propriedades necessárias ao Concrete damaged plasticity foram calibradas, obtendo-se um bom ajuste entre as curvas experimental e numérica de tensão-deformação até a tensão máxima de compressão. Também foram comparados os modos de ruptura experimental e numérico notando-se similaridade entre eles.

Uma vez que as propriedades do bloco e da argamassa ficaram bem ajustadas para a modelagem do prisma de três blocos com argamassamento parcial, admitiu-se que a compressão em temperatura ambiente do prisma formado por dois blocos e argamassamento total ficaria bem representada. Além disso, comparou-se o modo de ruptura numérico e experimental disponível em Izquierdo (2015) observando-se conformidade entre eles.

Nas simulações térmicas, conseguiu-se representar adequadamente a evolução de temperatura das faces não expostas ao fogo, mesmo sem dados experimentais da variação das propriedades térmicas do bloco brasileiro, utilizando-se, por analogia, as propriedades indicadas para o concreto disponíveis no Eurocode 2 Parte 1-2:2004. As modelagens foram validadas com um experimento fornecido pela empresa Glasser, disponível em Oliveira e Berto (2015) e com um resultado de grau corta-fogo apresentado em Chichierchio (1990).

Para a modelagem termomecânica, adotou-se a perda de resistência mecânica dos materiais devido à elevação de temperatura, também conforme dados disponíveis no Eurocode 2 Parte 1-2:2004. O critério de estanqueidade não foi avaliado, porém, verificaramse por meio da revisão bibliográfica que as paredes nas quais se avaliaram os três critérios se mantiveram estanques até as suas rupturas.

Notou-se que a restrição de deslocamento vertical e/ou a aplicação de um maior nível de carregamento antecipa a ruptura do prisma. Além disso, constatou-se que a falta de 
restrição rotacional gera um modo de ruptura diferente do caso com restrição rotacional e em tempo inferior de incêndio.

A situação de incêndio nas duas faces do prisma causou a sua ruptura teórica em tempo inferior ao caso de incêndio em uma única face, em consequência de sua maior deterioração térmica. Entretanto, para uma parede, o mesmo poderá não acontecer. Por ser um elemento mais esbelto, o efeito do encurvamento produzido pela ação térmica pode ser ainda mais prejudicial que a maior deterioração térmica causada pelo incêndio nas duas faces.

Considerando que os prismas se mantenham estanques até as suas ruínas, aquele sem revestimento foi avaliado por meio da simulação térmica e termomecânica com grau cortafogo CF60. Contanto que não ocorra o desprendimento da argamassa durante o incêndio, a aplicação de revestimento nas duas faces elevou a resistência do prisma para grau corta-fogo CF120, sendo este o maior tempo requerido de resistência ao fogo (TRRF) exigido pela ABNT NBR 14432:2001.

O emprego da perda de resistência à compressão, com propriedades físicas indicadas pelo Eurocode 2 Parte 1-2:2004, levou a um resultado de tempo inferior de resistência mecânica ao apresentado em Chichierchio (1990), sendo favorável à segurança. Entretanto, os resultados das simulações termomecânicas não foram validados com experimentos. Como os prismas são elementos curtos, o efeito do encurvamento térmico não pode ser detectado como prejudicial às suas resistências.

Diante dos resultados obtidos e estudo sobre o tema realizado no presente trabalho, apresentam-se sugestões para trabalhos futuros.

i Aferir em experimentos a elevação de temperatura em outros pontos da seção transversal do bloco, além da face não exposta ao fogo, para checar se a simulação térmica representa bem a sua elevação de temperatura;

ii Verificar por meio de ensaios laboratoriais a perda de resistência de blocos de concreto brasileiros conforme a elevação de temperatura, possibilitando a elaboração de uma tabela como a disponível no Eurocode 2 Parte 1-2:2004;

iii Realizar ensaios de resistência ao fogo de paredes carregadas constituídas por blocos de concreto e com uma face exposta ao incêndio, verificando o efeito do encurvamento térmico; 
iv Simular o comportamento da parede carregada constituída por blocos de concreto e em situação de incêndio e comparar os resultados de deslocamento vertical e lateral numéricos e experimentais. Realizar variações na simulação, reunindo dados para uma futura normatização nacional de dimensionamento de alvenaria estrutural em situação de incêndio. 


\section{REFERÊNCIAS}

ABBOTT, M. M.; VAN NESS, H. C. Introdução à Termodinâmica na Engenharia Química. Smith $7^{\text {a }}$ Edição, 2007.

ALVES, L. A. Análise acoplada de temperatura e umidade no concreto em altas temperaturas. Dissertação (Mestrado) - Universidade Federal do Rio de Janeiro, Rio de Janeiro, 77 p. 2014.

ALVES, L; BORBOREMA, M. Dados sobre incêndio podem dar a dimensão real do problema no país. Instituto Sprinkler Brasil. 2015. Disponível em:

$<$ http://www.sprinklerbrasil.org.br/imprensa/dados-sobre-incendio-podem-dar-a-dimensaoreal-do-problema-no-pais/>. Acesso em: 24 out. 2016.

AMERICAN SOCIENTY OF CIVIL ENGINEERS - ASCE. Structural Fire Protection. Manuals and Reports on Engineering Practice N ${ }^{\circ}$ 78. T.T. Lie Editor. 241 p. New York, 1992. ISBN 0-87262-888-4.

ANDREINI, M.; CACIOLAI, M.; MENDOLA, S. LA; MAZZIOTTI, L.; SASSU, M. Mechanical behavior of masonry materials at high temperatures. Fire and Materials. John Wiley \& Sons, LTD, 2014.

ANDREINI, M.; SASSU, M. Mechanical behaviour of full unit masonry panels under fire action. Fire Safety Journal, Elsevier, 46 (7), pp.440, 2011.

ARAÚJO, M. C. M. Diferentes visões da Nebulosa de Órion. Awesome Universe, 2013. Disponível em: <http://awesomeuniverse.org/2013/09/11/diferentes-visoes-da-nebulosa-deorion/>. Acesso em: 18 jan. 2017.

ASSOCIAÇÃO BRASILEIRA DA INDÚSTRIA DE BLOCOS DE CONCRETO - BLOCO BRASIL. Manual de Desempenho - Alvenaria com Blocos de Concreto. $2^{\circ}$ Edição Revisada e Atualizada. ISBN 978-85-87024-82-4. 38 p. 2016.

ASSOCIAÇÃO BRASILEIRA DE NORMAS TÉCNICAS. NBR 13860: Glossário de termos relacionados com a segurança contra incêndio. Rio de Janeiro, 1997.

ASSOCIAÇÃO BRASILEIRA DE NORMAS TÉCNICAS. NBR 14432: Exigências de resistência ao fogo de elementos construtivos de edificações - Procedimento. Rio de Janeiro, 2001.

ASSOCIAÇÃO BRASILEIRA DE NORMAS TÉCNICAS. NBR 5628: Componentes construtivos estruturais - Determinação da resistência ao fogo. Rio de Janeiro, 2001.

ASSOCIAÇÃO BRASILEIRA DE NORMAS TÉCNICAS. NBR 15220: Desempenho térmico de edificações parte 2: Métodos de cálculo da transmitância térmica, da capacidade térmica, do atraso térmico e do fator solar de elementos e componentes de edificações. Rio de Janeiro, 2005. 
ASSOCIAÇÃO BRASILEIRA DE NORMAS TÉCNICAS. NBR 15812: Alvenaria estrutural

- Blocos cerâmicos parte 1: Projetos. Rio de Janeiro, 2010

ASSOCIAÇÃO BRASILEIRA DE NORMAS TÉCNICAS. NBR 15961: Alvenaria estrutural - Blocos de concreto parte 1: Projeto. Rio de Janeiro, 2011.

ASSOCIAÇÃO BRASILEIRA DE NORMAS TÉCNICAS. NBR 16522: Alvenaria de blocos de concreto - Métodos de ensaio. Rio de Janeiro, 2016.

ASSOCIAÇÃO BRASILEIRA DE NORMAS TÉCNICAS. NBR 6136: Blocos vazados de concreto simples para alvenaria - Requisitos. Rio de Janeiro, 2016.

ASSOCIAÇÃO BRASILEIRA DE NORMAS TÉCNICAS. NBR 15270: Componentes cerâmicos - Blocos e tijolos para alvenaria parte 1: Requisitos. Rio de Janeiro, 2017.

AMERICAN SOCIETY FOR TESTING AND MATERIALS. ASTM E119: Standard Methods of Fire Test of Building Construction and Materials. West Conshohocken, PA, 2000.

AYALA, F. R. R. Mechanical properties and structural behaviour of masonry at elevated temperatures. Thesis - The University of Manchester. School of Mechanical, Aerospace and Civil Engineering. 294 p. 2010.

BBC. Como as portas trancadas de um shopping durante incêndio mataram mais de 60 na Rússia. 2018. Disponível em: < http://www.bbc.com/portuguese/internacional43549840>. Acesso em: 17 abr. 2018.

BIRTEL, V.; MARK, P. Parameterised finite element modelling of RC beam shear failure. ABAQUS Users' Conference, 2006, p. 95-108.

BRICK INDUSTRY ASSOCIATION - BIA. Technical Note 16: Fire resistance of brick masonry. Reston, VA, 2008. 16 p.

BUCHANAN, A. H. Structural Design for Fire Safety. University of Canterbury, New Zealand. John Wiley \& Sons, LTD, 421 p. 2002.

BUtTler, A. M., FREITAS, PRADO, A. A., CORRÊA, M. R. S., RAMALHO, M. A. Influência do contato da argamassa com o bloco de concreto nas suas propriedades físicas e mecânicas. XXXII Jornadas Sul-americanas de Engenharia Estrutural. 10 p. 2006.

CÁNOVAS, F. M. Ação do fogo sobre as estruturas. In: CÁNOVAS, F. M. Patologia e terapia do concreto armado. São Paulo: Pini, 1988. Cap. 8, p. 173-201.

CARDOSO, H. S. Estudo teórico-experimental de parafusos utilizados como dispositivos de transferência de carga em pilares mistos tubulares preenchidos com concreto. Belo Horizonte, 2014, 206 p. Dissertação (Mestrado). Universidade Federal de Minas Gerais, Escola de Engenharia, 2014.

CARREIRA, D. J.; CHU, K. H. Stress-strain relationship for plain concrete in compression. ACI Journal Technical Paper. Title no 82-72, 8 p.1985. 
CAVALHEIRO, O. P. Alvenaria estrutural. Universidade Federal de Santa Maria, Santa Maria - RS. 2009. 8 p. Disponível em:

<http://www.ceramicapalmadeouro.com.br/downloads/cavalheiro1.pdf >. Acesso em: 27 set. 2016.

CHICHIERCHIO L. C. Conforto ambiental: desempenho térmico e acústico e proteção contra o fogo. In: Associação Brasileira da Construção Industrializada - ABCI. Manual Técnico de Alvenaria. São Paulo, p. 119-141, 1990.

COLE-PARMER INSTRUMENT COMPANY. Emissivity of specific materials. United States, 2017. Disponível em: <https://www.coleparmer.com/tech-article/emissivity-ofspecific-materials> Acesso em: 12 dez. 2017.

COSTA, S. N.; SILVA, V. P. Revisão histórica das curvas padronizadas de incêndio. Núcleo de Pesquisa em Tecnologia da Arquitetura e Urbanismo da Universidade de São Paulo. Ed. Paula Souza. 13 p. 2006.

CTIF, Centre of Fire Statistics (International Association of Fire and Rescue Services). World fire statistics. Report n. 21, 2016. Disponível em: $<$ http://www.ctif.org/sites/default/files/ctif_report21_world_fire_statistics_2016.pdf>. Acesso em: 24 out. 2016.

CTIF, Centre of Fire Statistics (International Association of Fire and Rescue Services). World fire statistics. Report n. 22, 2017. Disponível em:

$<$ http://www.ctif.org/sites/default/files/ctif_report22_world_fire_statistics_2017.pdf >. Acesso em: 23 dez. 2017.

CÜLFIK, M. S.; ÖZTURAN, T. Effect of elevated temperatures on the residual mechanical properties of high-performance mortar. Cement and Concrete Research 32 . p. 809-816, 2012.

DONOSO, J. P. Calor, energia e transferência de calor. Universidade de São Paulo, Instituto de Física de São Carlos. 25 p. 2009.

DRYSDALE, D. An Introduction to Fire Dynamics. University of Edinburgh, UK. John Wiley \& Sons, LTD. 2. ed. 451 p. 1998.

DRYSDALE, R. G.; HAMID, A. A.; BAKER, L. R. Masonry Structures: Behavior and Design. Englewood Cliffs: Prentice-Hall, New Jersey, 1994. 784 p.

EUROPEAN COMMITTEE FOR STANDARDIZATION. Eurocode 1: EN 1991-1.2: Actions on structures: Part 1-2: General actions - Actions on structures exposed to fire. Brussels, 2002.

EUROPEAN COMMITTEE FOR STANDARDIZATION. Eurocode 2: EN 1992-1.2: Design of concrete structures: Part 1-2: General rules - Structural fire design. Brussels, 2004. 
EUROPEAN COMMITTEE FOR STANDARDIZATION. Eurocode 6: EN 1996-1.2: design of masonry structures: Part 1-2: general rules: structural fire design. Brussels, 2005.

FÉDÉRATION INTERNATIONALE DU BÉTON - FIB. Fire design of concrete structures - materials, structures and modelling. State-of-art report, bulletin 38, 105 p., 2007.

FÉDÉRATION INTERNATIONALE DU BÉTON - FIB. Fire design of concrete structures - structural behavior and assessment. State-of-art report, bulletin 46, 216 p., 2008.

FÉDÉRATION INTERNATIONALE DU BÉTON - FIB. Code-type models for structural behavior of concrete. State-of-art report, 2013.

HALLIDAY, D.; RESNICK, R.; KRANE, K. S. Física 2. Rio de Janeiro: Livros Técnicos e Científicos, 1996. 4. ed. 289 p.

INTERNATIONAL ORGANIZATION FOR STANDARDIZATION. ISO 834: Fire resistance tests - elements of building construction: Part 1. General requirements. Gèneve, 1999.

IZQUIERDO, O. S. Estudo da interface bloco/graute em elementos de alvenaria estrutural. Tese (Doutorado) - Escola de Engenharia de São Carlos, Universidade de São Paulo, São Carlos, 322p. 2015.

KHALIQ, W.; BASHIR, M. F. High temperature mechanical and material properties of burnt masonry bricks. Materials and Structures. (C) RILEM, 2016.

LEITE, H. A. L.; MORENO JÚNIOR, A. L.; TORRES, D. L. Dimensionamento da alvenaria estrutural em situação de incêndio: Contribuição à futura normatização nacional. Ambiente Construído, Porto Alegre, v. 16, n. 2, p. 89-107, abr./jun. 2016.

LOURENÇO, P. J. B. B. Computational strategies for masonry structures. 1996. 220 p.

Delft University Press. Thesis Delft University of Thechnology, 1996.

LOURENÇO, P. B.; ROTS, J. G. Multisurface interface model for analysis of masonry structures. Journal of Engineering Mechanics, p. 660-668, July 1997.

MORENO JÚNIOR, A. L.; MOLINA, J. C. Considerações de interesse sobre a avaliação em laboratório de elementos estruturais em situação de incêndio: contribuições à revisão da NBR 5628/2001. Ambiente Construído, Porto Alegre, v. 12, n. 4, p. 37-53, out./dez. 2012.

NADJAI, A.; ALI, F. Compartment masonry walls in fire situations. Springer Science + Business Media, LLC. Manufactured in The United States. Fire Technology, 42, p. 211-231, 2006.

NADJAI, A.; O'GARRA, M.; ALI, F. A; LAVERTY, D. A numerical model for the behaviour of masonry under elevated temperatures. Fire and Materials 27, p 163-182, 2003.

NAHHAS, F. AL; AMI SAADA, R.; BONNET, G.; DELMOTTE, P. Resistance to fire of walls constituted by hollow blocks: Experiments and thermal modeling. Science Direct. Applied Thermal Engineering 27, p.258-267, 2007. 
NATIONAL FIRE PROTECTION ASSOCIATION - NFPA. All about fire. Disponível em: $<$ http://www.nfpa.org/news-and-research/news-and-media/press-room/reporters-guide-to-fireand-nfpa/all-about-fire>. Acesso em: 08 nov. 2016.

NEVES, C. I. The critical temperature of steel columns with restrained thermal elongation. Fire Safety Journal 24 p. 211-227, 1995.

NGUYEN, T. D.; MEFTAH, F.; CHAMMAS, R.; MEBARKI, A. The behaviour of masonry walls subjected to fire: Modelling and parametrical studies in the case of hollow burnt-clay bricks. Fire Safety Journal 44 p. 629-641, 2009.

NGUYEN, T. D.; MEFTAH, F. Behavior of clay hollow-brick masonry walls during fire. Part 1: Experimental analysis. Fire Safety Journal 52 p. 55-64, 2012.

NIKOLAEV, V. I. Modeling of temperature field of "Besser" concrete blocks under standard fire conditions. Journal of Engineering Physics and Thermophysics, Vol. 70, No. 2, 1997.

OLIVEIRA, C. R. M.; BERTO, A. F. Determinação da resistência ao fogo em parede sem função estrutural. São Paulo: IPT, 2015. Relatório de ensaio nº 1 072 608-203. 12 p.

OLIVEIRA JR., V. Recomendações para projetos de edifícios em alvenaria estrutural. 1992. 273 p. Dissertação (Mestrado em Estruturas). Escola de Engenharia de São Carlos, Universidade de São Paulo, São Carlos, 1992.

OLIVEIRA, L. M. F. Estudo teórico e experimental do comportamento das interfaces verticais de paredes interconectadas de alvenaria estrutural. São Carlos, 2014, 272 p. Tese (Doutorado em Engenharia de Estruturas) Escola de Engenharia de São Carlos, Universidade de São Paulo, São Carlos, 2014.

PELETEIRO, S. C. Contribuições à modelagem numérica de alvenaria estrutural. São Carlos, 2002, 143 p. Dissertação (Doutorado). Escola de Engenharia de São Carlos, Universidade de São Paulo, 2002.

RAMALHO, M. A.; CORRÊA, M. R. S.. Projeto de edifícios de alvenaria estrutural. São Paulo, Pini, 2003. 174 p.

RIGÃO, A. O. Comportamento de Pequenas Paredes de Alvenaria Estrutural Frente a Altas Temperaturas. Santa Maria, 2012. 142 p. Dissertação (Mestrado em Engenharia Civil) - Escola de Engenharia, Universidade Federal de Santa Maria, São Maria, 2012.

ROCHA, F. M. Pilares de Aço e Mistos de Aço e Concreto Inseridos em Paredes em Situação de Incêndio. 2016. 262 p. Tese (Doutorado em Engenharia Civil (Estruturas)) Escola de Engenharia de São Carlos, Universidade de São Paulo, São Carlos, Brasil. Universidade de Coimbra, Portugal, 2016.

ROSEMANN, F. Resistência ao fogo de paredes de alvenaria estrutural de blocos cerâmicos pelo critério de isolamento térmico. 2011. 160 p. Dissertação (Mestrado em Engenharia Civil). Universidade Federal de Santa Catarina, Florianópolis, 2011. 
RUDLOFF. Aparelhos de apoio metálicos elastométricos. 22 p. Rev. 5 -10/2015.

RUSSO, S.; SCIARRETTA, F. Masonry exposed to high temperatures: Mechanical behavior and properties - An overview. Fire Safety Journal 55, 2013, p. 69-86.

RUSSO, S.; SCIARRETTA, F. Numerical study on the residual mechanical performance of traditional brickwork after standard fire exposure. International Conference on Structural Analysis of Historical Constructions. Mexico City, Mexico, 12 p. 2014.

RUSSO, S.; SCIARRETTA, F. Numeric research on the mechanical properties of different masonry units during and after fire. Brick and Block Masonry - Trends, Innovations and Challenges - Modena, da Porto \& Valluzzi (Eds). Taylor \& Francis Group, London, 999-1005, 2016.

SANTOS, C.F.R.; ALVARENGA, R.C.S.S.; RIBEIRO, J.C.L.; CASTRO, L.O.; SILVA, R.M. SANTOS, A.A.L.; NALON,G.H. Numerical and experimental evaluation of masonry prisms by finite element method. Revista IBRACON de Estruturas e Materiais. Vol. $10 \mathrm{n}^{\circ}$ $2,2017$.

SCHNEIDER, R. R.; DICKEY, W. L. Reinforced masonry design. Englewood Cliffs, New Jersey, Prentice Hall, 1994. 729 p.

SCHNEIDER, U. Concrete at high temperatures - A general review. Fire Safety Journal 13. 1988; p. 55-68.

SEITO, A. I.; GILL, A. A.; PANNONI, F. D.; ONO, R.; SILVA, S. B.; CARLO, U. D.; SILVA, V. P. A segurança contra incêndios no Brasil. São Paulo: Projeto Editora, 2008. 484 p.

SILVA, V. P. Sobre o coeficiente $\gamma_{\mathrm{s} 1}$ do método do tempo equivalente para a determinação do tempo requerido de resistência ao fogo das estruturas. Pesquisa e Tecnologia, Minerva, vol $5, \mathrm{n}^{\circ} 3,2008$, p. 315-321.

SILVA, V. P. Segurança das estruturas de concreto em situação de incêndio. Escola Politécnica da Universidade de São Paulo. Semana de Engenharia, Arquitetura e Agronomia de São Carlos, 2010.

SIMULIA. Abaqus Analysis. User’s Manual Volume III: Materials. 2012, 692 p.

STANCATO, A. C. Determinação da condutividade térmica e da resistência mecânica em argamassa leve. Dissertação (Mestrado). Universidade Estadual de Campinas Faculdade de Engenharia Civil. Campinas -SP, 184 p. 2000.

WANG, Y. C. Steel and Composite Structures. Behavior and design for fire safety. London, Spon Press, 2002, New York. 332 p. 